UNIVERSIDADE DE SÃO PAULO

ESCOLA DE ENGENHARIA DE SÃO CARLOS

DEPARTAMENTO DE ENGENHARIA DE ESTRUTURAS

FERNANDO MELLIN MOREIRA FERREIRA

\title{
INFLUÊNCIA DA INCORPORAÇÃO DE AR EM CONCRETO AUTOADENSÁVEL PARA PAREDES DE CONCRETO MOLDADAS NO LOCAL
}





\section{VERSÃO CORRIGIDA}

A versão original encontra-se na Escola de Engenharia de São Carlos

Dissertação apresentada ao Departamento de Engenharia de Estruturas da Escola de Engenharia de São Carlos, Universidade de São Paulo, como parte dos quesitos necessários para obtenção do título de Mestre em Engenharia Civil (Estruturas).

Orientadora: Prof. Dra. Alessandra Lorenzetti de Castro 
AUTORIZO A REPRODUÇÃO TOTAL OU PARCIAL DESTE TRABALHO, POR QUALQUER MEIO CONVENCIONAL OU ELETRÔNICO, PARA FINS DE ESTUDO E PESQUISA, DESDE QUE CITADA A FONTE.

Ficha catalográfica elaborada pela Biblioteca Prof. Dr. Sérgio Rodrigues Fontes da EESC/USP com os dados inseridos pelo(a) autor(a).

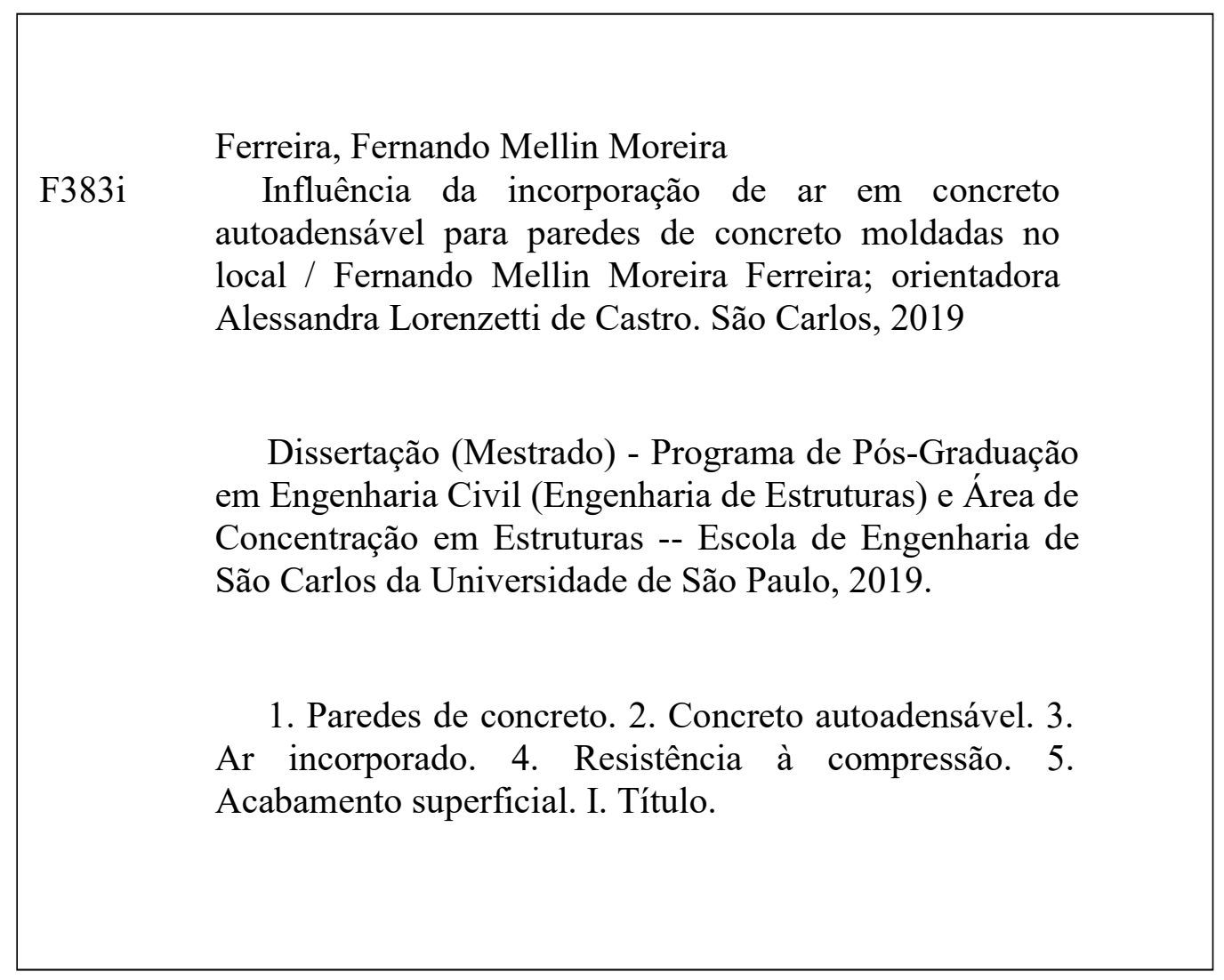

Eduardo Graziosi Silva - CRB - 8/8907 


\section{FOLHA DE JULGAMENTO}

Candidato: Engenheiro FERNANDO MELLIN MOREIRA FERREIRA.

Título da dissertação: "Influência da incorporação de ar em concreto autoadensável para paredes de concreto moldadas no local".

Data da defesa: 22/04/2019.

Comissão Julgadora:

Resultado:

Profa. Dra. Alessandra Lorenzetti de Castro

Apriavado (Orientadora)

(Escola de Engenharia de São Carlos/EESC)

Profa. Dra. Fernanda Giannotil da Silva Ferreira

(Universidade Federal de São Carlos/UFSCar)

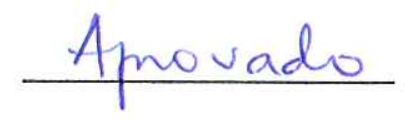

Profa. Dra. Valdirene Maria Silva Capuzzo

Aprovado

(Universidade de Brasília/UnB)

Coordenador do Programa de Pós-Graduação em Engenharia Civil (Engenharia de Estruturas):

Prof. Assoc. Vladimir Guilherme Haach

Presidente da Comissão de Pós-Graduação:

Prof. Titular Murilo Araujo Romero 



\section{AGRADECIMENTOS}

Agradeço primeiramente aos meus pais, Adi e Fernando, que me forneceram condições suficientes para que eu esteja onde estou hoje.

Agradeço à toda minha família pelo suporte e carinho ao longo de toda minha vida.

À minha namorada Thaís, por acompanhar minha jornada desde os tempos de graduação, me incentivando e fornecendo todo apoio quanto necessário desde então.

À Alessandra, pela excelente orientação e predisposição em sanar as dúvidas que surgiram ao longo do mestrado e ainda pela amizade e tranquilidade oferecidas nos últimos dois anos.

Aos amigos Herbert, Thomas, Alex, Lucas e tantos outros que tornaram a experiência do mestrado mais leve e agradável.

Aos funcionários do Laboratório de Estruturas da EESC, especialmente ao Jorge e ao Fabiano, pela ajuda em meus experimentos. Agradecimento especial aos amigos Herbert, Thomas, André, Mateus, Lucas, Bernardo, Alex, Gustavo e Alessandra, sem os quais não seria possível a conclusão de muitos dos ensaios desenvolvidos.

À Fernanda e ao José Roberto que permitiram o desenvolvimento de parte essencial deste trabalho no Laboratório de Materiais e Componentes da Construção Civil da UFSCar.

À Coordenação de Aperfeiçoamento de Pessoal de Nível Superior (CAPES), pelo financiamento da bolsa de pesquisa.

Aos funcionários do SET por toda a assistência fornecida durante o mestrado.

Às empresas GCP Applied Technologies, LafargeHolcim, Elkem e ULMA pelos materiais fornecidos que permitiram a existência deste trabalho. 




\section{RESUMO}

FERREIRA, F. M. M. Influência da incorporação de ar em concreto autoadensável para paredes de concreto moldadas no local. 2019. 195 p. Dissertação (Mestrado em Engenharia Civil (Estruturas)) - Escola de Engenharia de São Carlos, Universidade de São Paulo, São Carlos, 2019.

A criação de programas federais voltados para o desenvolvimento da infraestrutura brasileira no final da década passada resultou no aquecimento do setor de construção civil. Nesse contexto, o sistema de paredes de concreto moldadas no local se destacou devido à sua alta produtividade e repetitividade. Os requisitos e procedimentos para o dimensionamento de paredes de concreto moldadas no local são contemplados na NBR 16055:2012. Dentre as abordagens consideradas nessa norma, ressalta-se a recomendação do uso de concreto autoadensável. No entanto, alguns pontos de interesse não são contemplados na regulamentação vigente como, por exemplo, a incorporação de ar na composição do concreto, bem como os limites de teores de ar incorporado. Assim, a presente pesquisa busca avaliar a influência da incorporação de ar no comportamento de concretos autoadensáveis destinados à execução de paredes de concreto moldadas no local. Para isso, foram produzidos dois traços de concreto autoadensável de classes de resistência C25 e C40 e, a partir de cada um deles, produzidos outros dois traços modificados com aditivo incorporador de ar, variando o teor de ar incorporado, em um total de seis misturas cujas propriedades foram avaliadas tanto no estado fresco quanto no estado endurecido. Além disso, foram moldadas paredes de concreto a fim de analisar a estrutura interna do material com aparelho de ultrassom e o acabamento superficial do elemento por meio de análise de imagens. No caso da classe C25, os resultados demonstram que a influência do teor de ar para os traços modificados foi tão significativa que os concretos produzidos se tornaram inadequados para uso estrutural. Por outro lado, apesar da elevada perda de resistência à compressão aos 28 dias, os dois traços produzidos com incorporação de ar no concreto de classe C40 se adequam às recomendações da NBR 16055:2012. Alia-se a isso o fato de que, quando da execução das paredes em laboratório, os concretos utilizados demonstraram grande capacidade de preenchimento, resultando em elementos com bom acabamento superficial e estrutura interna homogênea, mesmo em regiões de difícil acesso. Sendo assim, o presente trabalho propõe traços muito promissores para utilização em paredes de concreto moldadas no local.

Palavras-Chave: Paredes de concreto. Concreto autoadensável. Ar incorporado. Resistência à compressão. Acabamento superficial. 



\begin{abstract}
FERREIRA, F. M. M. The influence of air entrainment on self-compacting concrete for concrete walls cast in place. 2019. 195 p. Dissertation (M. Sc. in Civil Engineering (Structures) ) - School of Engineering of São Carlos, University of São Paulo, São Carlos, 2019.

The creation of federal programs aimed at the development of Brazilian infrastructure at the end of the last decade resulted in the heating of civil construction sector. In this context, the system of concrete walls cast in place stood out due to its high productivity and repetitiveness. The requirements and procedures for the design of concrete walls cast in place are contemplated in the NBR 16055:2012. Among the several approaches considered in this code, the recommendation for the use of self-compacting concrete is emphasized. However, some points of interest are not considered in the current regulations, such as the incorporation of air in the concrete composition, as well as the limits for entrained air contents. Thus, the present research seeks to evaluate the influence of air entrainment in the behaviour of self-compacting concrete for the construction of concrete walls cast in place. For this, two self-compacting concrete mixes design of strength classes C25 and C40 were produced and, from each of them, two other mixes modified with air entraining admixture were produced, varying the entrained air content, in a total of six mixtures whose properties were evaluated in both fresh and hardened state. In addition, concrete walls were cast to analyse the internal structure with ultrasonic equipment and the element surface finish by image analysis. In the case of class C25, the results demonstrate that the influence of the air content for the modified mixes was so great that the concretes produced became inappropriate for structural use. On the other hand, despite the high loss of compressive strength at 28 days, the two mixes produced with entrained air in the concrete of class C40 respect the recommendations of the NBR 16055:2012. In addition, when the walls were cast in laboratory, the concretes used showed great filling capacity, resulting in structures with good surface finish and homogeneous internal structure, even in difficult access regions. Therefore, the present work proposes very promising mixes for use in concrete walls cast in place.
\end{abstract}

Keywords: Concrete walls. Self-compacting concrete. Entrained air. Compressive strength. Surface finish. 



\section{SUMÁRIO}

1 INTRODUÇÃO

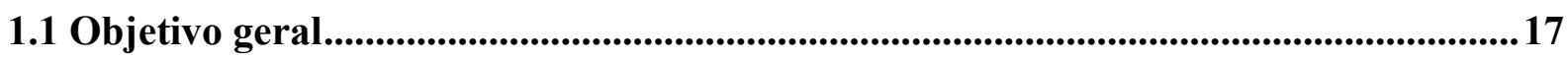

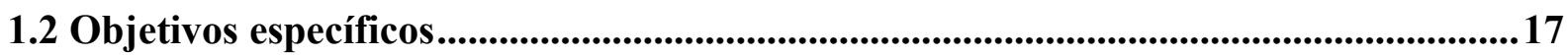

1.3 Importância do presente trabalho.....................................................................................18

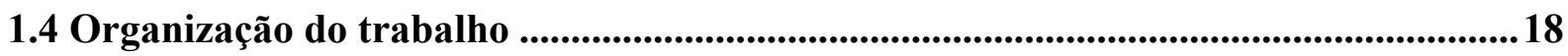

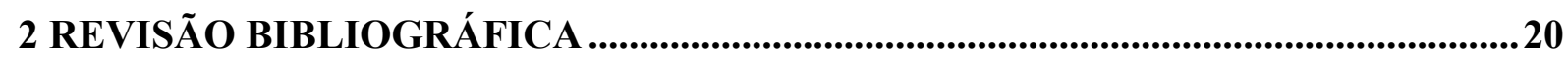

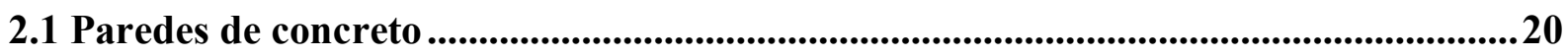

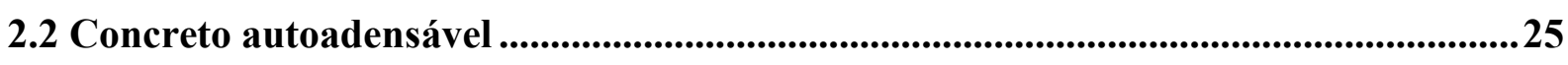

2.2.1 Comportamento no estado fresco............................................................................................. 27

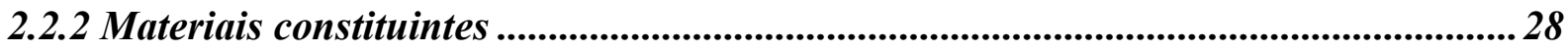

2.2.3 Métodos de dosagem ............................................................................................................... 29

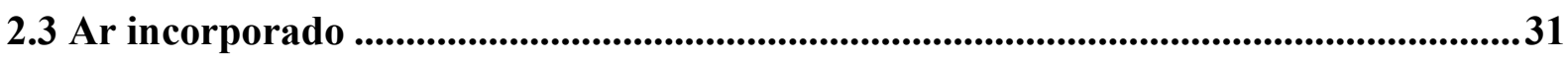

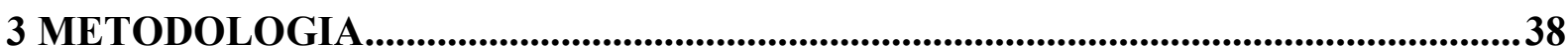

3.1 Método de dosagem ..........................................................................................................................38

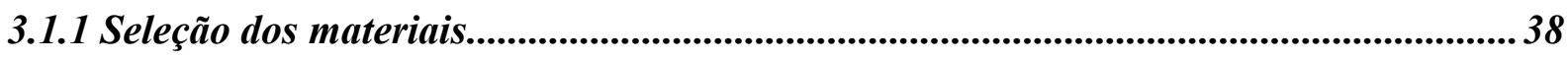

3.1.2 Definição da composição da pasta ...........................................................................40

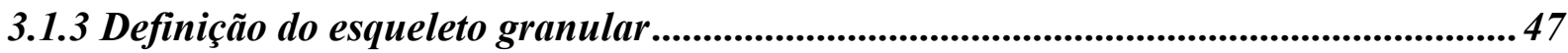

3.1.4 Determinação da composição do CAA ..............................................................49

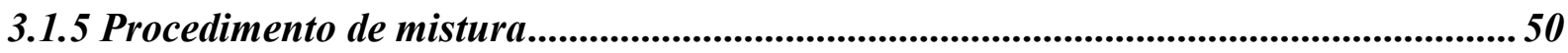

3.2 Medição das propriedades do concreto fresco ...........................................................53

3.2.1 Propriedades de autoadensabilidade do concreto .....................................................5 53

3.2.2 Determinação do teor de ar incorporado ao concreto..................................................... 64

3.3 Medição das propriedades do concreto endurecido ........................................................65

3.3.1 Ensaio de compressão de corpos de prova cilíndricos ..............................................65

3.3.2 Determinação da resistência à tração por compressão diametral de corpos de prova

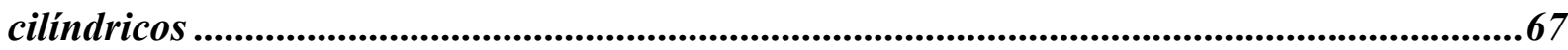

3.3.3 Determinação da resistência à tração na flexão de corpos de prova prismáticos........ 67

3.3.4 Determinação do módulo de elasticidade dinâmico ....................................................68

3.3.5 Ensaio de ultrassom em prismas........................................................................... 71

3.3.6 Análises estatísticas ........................................................................................................................ 74

3.4 Moldagem de paredes de concreto ....................................................................................75

3.5 Avaliação do acabamento superficial para os traços definidos.......................................78 
3.6 Avaliação da estrutura interna das paredes com ultrassom 82

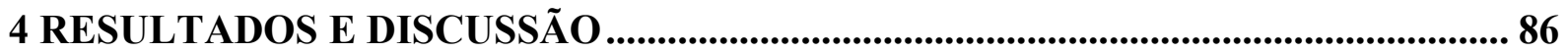

4.1 Dosagem do concreto autoadensável ........................................................................... 86

4.2 Caracterização dos concretos de referência ......................................................................... 95

4.2.1 Propriedades do concreto em estado fresco para traços de referência .......................... 95

4.2.2 Propriedades do concreto em estado endurecido para traços de referência................ 97

4.3 Caracterização dos concretos com ar incorporado................................................... 107

4.3.1 Propriedades do concreto em estado fresco para traços com ar incorporado ........... 109

4.3.2 Propriedades do concreto em estado endurecido para traços com ar incorporado... 116

4.4 Gráficos comparativos de propriedades dos concretos produzidos .......................... 132

4.5 Análises em modelos (painéis) reais de paredes ................................................................ 140

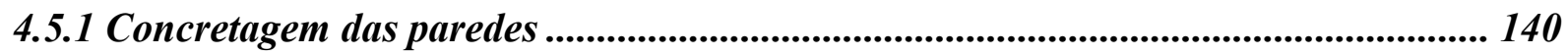

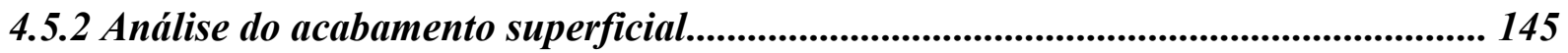

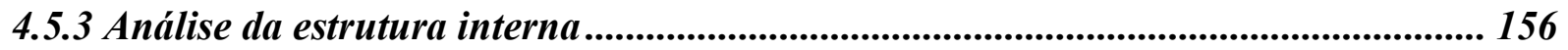

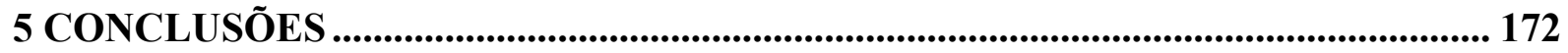

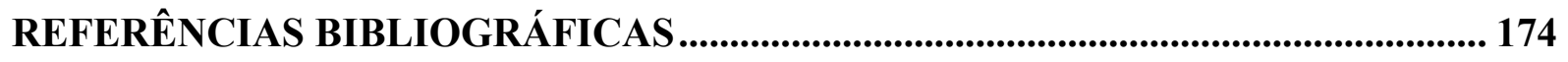

APENDICE A - CARACTERIZAÇÃO DOS MATERIAIS CONSTITUINTES ......... 180

APENDICE B - APLICAÇÃO DE CRITÉRIO DE CHAUVENET PARA VALORES

DE RESISTÊNCIA À COMPRESSÃO.................................................................. 183

APENDICE C - APLICAÇÃO DE CRITÉRIO DE CHAUVENET PARA VALORES

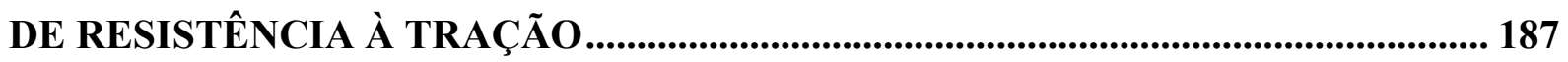

APENDICE D - TESTE T PARA AVALIAÇÃO DE DIFERENÇA SIGNIFICATIVA

ENTRE AMOSTRAS CONSIDERADAS ....................................................................... 192 


\section{INTRODUÇÃO}

O Brasil vivenciou num passado recente um momento de euforia na construção civil impulsionado principalmente por iniciativas do Governo Federal, como o Programa de Aceleração do Crescimento (PAC) e o Minha Casa Minha Vida (MCMV). Os dois programas se mantém até os dias atuais, sendo o PAC, lançado em 2007, voltado para o planejamento e execução de grandes obras de infraestrutura social, urbana, logística e energética do país ${ }^{1}$, enquanto que o MCMV, iniciado em 2009, é uma iniciativa que oferece condições atrativas para o financiamento de moradias nas áreas urbanas para famílias de baixa renda ${ }^{2}$.

A injeção de dinheiro na economia fez com que a indústria da construção brasileira passasse por períodos agitados decorrentes da grande demanda por edificações e, principalmente, pela facilidade de acesso da população ao crédito. Com isso, construtoras passaram a dar maior atenção a obras com maior velocidade de execução (COMUNIDADE DA CONSTRUÇÃO, 2007/2008).

Assim, o cenário que se instalou foi propício para a consagração no Brasil do sistema construtivo de paredes de concreto moldadas no local, conhecido pela grande velocidade de execução. O sistema consiste na moldagem de paredes e lajes maciças de concreto armado com telas metálicas centralizadas (SILVA, 2011), sendo que as paredes apresentam característica autoportante, ou seja, são responsáveis por suportar as cargas atuantes na estrutura (ABNT, 2012b).

Essa tecnologia oferece condições técnicas e econômicas adequadas para a produção de unidades habitacionais em larga escala, sem comprometer sua qualidade (COMUNIDADE DA CONSTRUÇÃO, 2007/2008). Reforçando esse conceito, Faria (2009) afirma que o sistema de paredes de concreto moldadas no local permite que os construtores obtenham alta produtividade, aliada a uma redução de custos com mão-de-obra e ainda minimização dos erros de execução, o que se torna possível a partir de projetos padronizados com um alto grau de repetitividade.

A partir de 2007, a Associação Brasileira de Cimento Portland (ABCP), a Associação Brasileira de Serviços de Concretagem (ABESC) e o Instituto Brasileiro de Telas Soldadas (IBTS) se uniram e formaram um movimento conhecido como Comunidade da

\footnotetext{
${ }^{1}$ MINISTÉRIO DO PLANEJAMENTO. Sobre o PAC. Disponivel em <http://www.pac.gov.br/sobre-o-pac > acesso em: 06 de março de 2019.

${ }^{2}$ CAIXA. O que é Minha Casa Minha Vida. Disponível em <http://www.caixa.gov.br/voce/habitacao/minha-casaminha-vida/urbana> acesso em 06 de março de 2019.
} 
Construção. Esse movimento foi responsável por lançar algumas coletâneas envolvendo o sistema construtivo de paredes de concreto entre os anos de 2007 e 2013. Esse material contribuiu para o avanço dessa tecnologia no Brasil, propondo, dentre outros fatores, requisitos mínimos de qualidade para os materiais utilizados e apresentando métodos de dimensionamento dessas estruturas.

Em 2012, o método foi regulamentado no Brasil por meio da NBR 16055:2012 Parede de concreto moldada no local para a construção de edificações - Requisitos e procedimentos (ABNT, 2012b). São perceptíveis as influências que essa norma teve das coletâneas sobre parede de concreto lançadas anteriormente pela Comunidade da Construção, principalmente a coletânea de ativos referente aos anos de 2007 e 2008. Porém, mesmo com a regulamentação, algumas exigências para o concreto ainda não estão bem definidas e é difícil o acesso aos traços utilizados por concreteiras para acompanhar o que vem sendo aplicado na prática.

Um problema frequente relacionado à execução das paredes de concreto moldadas no local é o adensamento do concreto, que ocorre devido à esbeltez dos elementos, à presença de telas soldadas em larguras estreitas, às instalações embutidas e, ainda, aos recortes nas paredes que originam cantos de difícil acesso para o concreto. Assim, o modo de adensamento deve ser definido em função da geometria das peças estruturais, densidade das armaduras e tipo de concreto (COMUNIDADE DA CONSTRUÇÃO, 2009/2010), atentando-se para a utilização de vibradores de imersão, que podem danificar as fôrmas e ainda causar o deslocamento das instalações embutidas nas paredes. Atualmente a NBR 16055:2012 recomenda a utilização de concreto autoadensável (CAA) para a execução desses elementos, a fim de que sejam evitados possíveis problemas relacionados à concretagem das paredes de concreto (ABNT, 2012b).

De acordo com a NBR 15823-1:2017 - Concreto autoadensável - Parte 1: Classificação, controle e recebimento no estado fresco, o CAA é definido como o "concreto capaz de fluir, autoadensar pelo seu peso próprio, preencher a fôrma e passar por embutidos (armaduras, dutos e insertos), enquanto mantém sua homogeneidade (ausência de segregação) nas etapas de mistura, transporte, lançamento e acabamento" (ABNT, 2017a).

Desde seu desenvolvimento, a tecnologia do CAA vem sendo mais claramente aproveitada pela indústria do concreto pré-moldado (CPM), já que é possível a concretagem de elementos com altas taxas de armadura, diminuição da mão-de-obra na operação de moldagem e ainda uma redução do ruído proveniente de vibradores e fôrmas vibratórias utilizados em concretos convencionais (EL DEBS, 2017). Essas mesmas vantagens são observadas na 
execução de paredes de concreto moldadas no local, reforçando o estudo de CAA utilizado para essa finalidade.

Em se tratando do aumento da trabalhabilidade em concretos, a utilização de aditivos incorporadores de ar é outra estratégia que pode ser adotada. Esses aditivos apresentam estrutura química típica que consiste em cadeia hidrocarbônica apolar com um grupo polar aniônico em sua extremidade, o que faz com que vazios de ar sejam incorporados e estabilizados quando da sua adição ao concreto (MEHTA; MONTEIRO, 2014).

A melhora da trabalhabilidade nas misturas de concreto produzidas com aditivo incorporador de ar acontece como um efeito colateral causado pelo ar incorporado, associada a uma redução da massa específica do concreto e, consequentemente, redução do peso próprio da estrutura que permite que sejam consideradas cargas mais brandas no dimensionamento dos elementos estruturais. Porém, aliado a essas vantagens em relação ao concreto fresco, as misturas de concreto com ar incorporado em determinadas quantidades sofrem perda de resistência mecânica quando do estado endurecido (MEHTA; MONTEIRO, 2014). Portanto, é necessário que se faça uma análise dos efeitos negativos frente às vantagens obtidas em decorrência da incorporação de ar para que os resultados práticos na construção de paredes de concreto se enquadrem na regulamentação brasileira.

De maneira mais específica, os efeitos da incorporação de ar em CAA ainda são pouco conhecidos, sendo de grande interesse um maior entendimento de seu uso conjunto, objetivando a construção de paredes de concreto moldadas no local.

\subsection{Objetivo geral}

Avaliar a influência da incorporação de ar em concreto autoadensável a ser utilizado na construção de paredes de concreto moldadas no local.

\subsection{Objetivos específicos}

Produzir misturas de CAA com características necessárias à execução de paredes de concreto moldadas no local, respeitando os limites impostos pelas normas brasileiras.

Avaliar a influência de aditivo incorporador de ar sobre o comportamento dos CAAs, tanto em seu estado fresco quanto endurecido.

Avaliar, com uso de software de tratamento de imagem, o acabamento superficial de painéis de paredes de concreto moldadas com CAA sem e com aditivo incorporador de ar. 
Avaliar, com uso de aparelho de ultrassom, a qualidade de execução (homogeneidade de preenchimento) das paredes concretadas com CAA.

\subsection{Importância do presente trabalho}

Assim como apresentado, mesmo com a regulamentação de requisitos e procedimentos para paredes de concreto moldadas no local no Brasil por meio da NBR 16055:2012, ainda existem pontos não esclarecidos em relação ao concreto a ser utilizado na execução dessas paredes. Isso se torna bastante crítico quando se trata da incorporação de ar, já que essa norma não aborda os limites permitidos para o teor de ar incorporado. A análise se torna ainda mais complexa nos casos em que a incorporação de ar acontece em concretos autoadensáveis, já que não existe muita literatura que abranja essa situação.

Dado o aumento no uso do sistema construtivo de paredes de concreto moldadas no local, é de grande interesse um maior conhecimento acerca dos efeitos de incorporadores de ar em concretos autoadensáveis para que sejam desenvolvidos traços mais eficientes para o dimensionamento e execução das mesmas. Dessa maneira, o presente trabalho pretende propor traços de concretos autoadensáveis com ar incorporado em diferentes teores, validando suas propriedades para produção de paredes de concreto.

Em linhas gerais, este trabalho consiste no prosseguimento de uma dissertação de mestrado apresentada por Santos (2012). No trabalho em questão, foi estudada a influência da incorporação de ar em concretos autoadensáveis, sendo que o autor sugere a continuação da pesquisa com adequação do teor de ar incorporado e com a utilização de materiais pétreos com qualidade superior aos empregados em sua pesquisa, já que se fez a consideração de que os agregados utilizados provavelmente afetaram negativamente os resultados da pesquisa.

\subsection{Organização do trabalho}

O capítulo 1, correspondente à introdução do trabalho, faz uma breve apresentação dos principais temas em estudo. Também estão mostrados nesse capítulo os objetivos geral e específicos e a importância do presente trabalho.

No capítulo 2 está apresentada uma revisão bibliográfica que contextualiza os grandes temas de interesse: paredes de concreto, concreto autoadensável e ar incorporado. Este capítulo aborda com maior profundidade os conceitos presentes em literatura que discute os temas indicados. 
No capítulo 3 está indicada a metodologia de trabalho adotada, apresentando em detalhes o método de dosagem utilizado e os ensaios desenvolvidos, estabelecendo ainda quais são os requisitos de interesse.

O capítulo 4 apresenta os resultados obtidos nos ensaios e desenvolve discussões acerca dos pontos de maior importância do presente trabalho.

O capítulo 5 conclui o trabalho elencando os principais resultados obtidos e fazendo sugestões para trabalhos futuros.

Por fim são apresentadas as referências consultadas para o desenvolvimento desta pesquisa, seguidas dos apêndices que reúnem informações de auxílio ao texto principal. 


\section{REVISÃO BIBLIOGRÁFICA}

Na sequência é apresentada revisão bibliográfica acerca dos três grandes temas que compõem o presente estudo: paredes de concreto, concreto autoadensável e ar incorporado.

\subsection{Paredes de concreto}

A partir da criação do Banco Nacional de Habitação (BNH), em 1966, começaram a surgir os principais programas habitacionais brasileiros. Ao mesmo tempo, se fez presente o interesse de construtoras e fabricantes de materiais por novas tecnologias e processos construtivos não-convencionais (NUNES, 2011).

Dentre os processos construtivos utilizados nas décadas de 1970 e 1980, podem-se destacar experiências consagradas e bem-sucedidas de construções industrializadas, como os sistemas Gethal em concreto celular e o Outinord em concreto convencional, e ainda várias obras com painéis de fôrmas deslizantes ou trepantes. Porém, a falta de escala e de continuidade das obras decorrente, sobretudo, das limitações do sistema financeiro da habitação da época, impediu a consolidação dessas tecnologias no mercado brasileiro (COMUNIDADE DA CONSTRUÇÃO, 2007/2008).

Ainda que existam exemplos de construções no sistema de paredes de concreto desde os anos de 1970, o sistema ganhou força no Brasil em meados dos anos 2000, se consagrando como uma das principais técnicas construtivas adotadas no programa MCMV (MONGE; SILVA; VAQUERO Y MAYOR, 2018). Segundo Comunidade da Construção (2007/2008), no final da década de 2000, o boom do mercado imobiliário nacional proporcionou uma grande demanda por moradias e uma vigorosa produção de edificações, principalmente para habitações de interesse social.

Sacht (2008) apresenta que são vários os sistemas construtivos utilizados no Brasil para a construção de habitações de interesse social, podendo ser identificados sistemas convencionais, nos quais a montagem e execução ocorre principalmente na obra utilizando técnicas tradicionais; sistemas racionalizados, que se diferenciam dos convencionais pela utilização de parte dos elementos pré-fabricados; e ainda os sistemas industrializados, que se caracterizam pela produção em fábrica e montagem no canteiro.

Segundo Bezerra (2010), as construtoras procuram soluções tecnológicas que possam suprir a necessidade de produção em larga escala, fazendo uso de sistemas construtivos racionalizados no desenvolvimento de projetos e execução de edificações. Misurelli e 
Massuda (2009) explicam que, com o aquecimento do mercado imobiliário brasileiro e as medidas públicas para ampliar a oferta de moradias, o sistema de paredes de concreto representou uma solução factível para produção em larga escala. De acordo com Monge, Silva e Vaquero y Mayor (2018), é estimado que no ano de 2014 esse sistema estava presente em $36 \%$ das unidades construídas pelo programa.

Essa tipologia construtiva teve início na Europa com o término da II Guerra Mundial, com as construções com fôrmas tipo túnel, que executavam simultaneamente paredes e lajes. Com a destruição causada pela guerra, surgiu a necessidade de implantação de um sistema construtivo rápido e executado em larga escala, de forma a atender a demanda por habitações. A evolução da tecnologia envolvendo os sistemas de paredes de concreto permitiu que fossem produzidas habitações a baixo custo com níveis satisfatórios de desempenho (BEZERRA, 2010).

O primeiro registro da utilização do sistema construtivo de paredes de concreto no Brasil foi em 1979, com a construção de 46 unidades habitacionais por parte da COHAB-MG na cidade de Santa Luzia-MG (SACHT, 2008). ABCP (2002) apresenta que na década de 1980 foram construídas casas populares nas cidades de Natal (RN) e Manaus (AM) fazendo uso desse sistema construtivo.

A experiência obtida nas primeiras construções promoveu o aprimoramento da técnica, com o emprego de fôrmas modulares racionalizadas, e melhoria da qualidade do produto final (ABCP, 2002).

De acordo com Monge, Silva e Vaquero y Mayor (2018), as paredes de concreto moldadas no local são muito utilizadas em diversos segmentos habitacionais de países como Chile, Colômbia e México. De acordo com Nunes (2011), isso ocorre porque, além das vantagens em termos de prazo, custos e qualidade, as paredes de concreto consistem em um sistema estrutural monolítico, característica importante em regiões suscetíveis a abalos sísmicos.

A racionalização dos serviços aparece como uma das principais características desse sistema construtivo. Com ela, pode-se potencializar a produtividade da mão-de-obra em função de treinamento direcionado (COMUNIDADE DA CONSTRUÇÃO, 2007/2008). De acordo com Bezerra (2010), o sistema de paredes de concreto tem se mostrado interessante para o gerenciamento e acompanhamento de obras, com produtividade maior do que a obtida em construções convencionais.

No sistema em questão, a qualidade é garantida pelo uso de fôrmas com grande precisão dimensional, materiais com produção controlada e ainda atividades planejadas, de 
maneira que se otimize a produção dentro dos requisitos estabelecidos para qualidade (COMUNIDADE DA CONSTRUÇÃO, 2007/2008).

Sacht (2008) elaborou um esquema comparativo de vantagens e desvantagens do sistema de paredes de concreto (Tabela 2.1) com base no que está exposto em Lordsleem Júnior et al. (1998).

No Brasil, a NBR 16055:2012 estabelece os requisitos básicos para as paredes de concreto moldadas no local, definindo-as como elementos estruturais autoportantes que apresentam comprimento maior que dez vezes a espessura e capazes de suportar carga no mesmo plano da parede. A norma em questão se aplica às paredes submetidas à carga axial, concretadas com todos os elementos que farão parte da construção final, considera as lajes incorporadas ao sistema por solidarização com as paredes, tornando o sistema monolítico, e é válida para edifícios simplificados que atendem às seguintes condições (ABNT, 2012b):

- Lajes de vão livre máximo de 4 m e sobrecarga máxima de 300 kgf $/ \mathrm{m}^{2}$, não sendo admitidas lajes pré-moldadas;

- Distância de piso a piso máximo da construção de $3 \mathrm{~m}$;

- Dimensões em planta de, no mínimo, $8 \mathrm{~m}$.

As Figuras 2.1 a 2.4 apresentam diferentes etapas da construção de paredes de concreto moldadas no local.

Figura 2.1 - Armação e posicionamento de instalações em lajes.

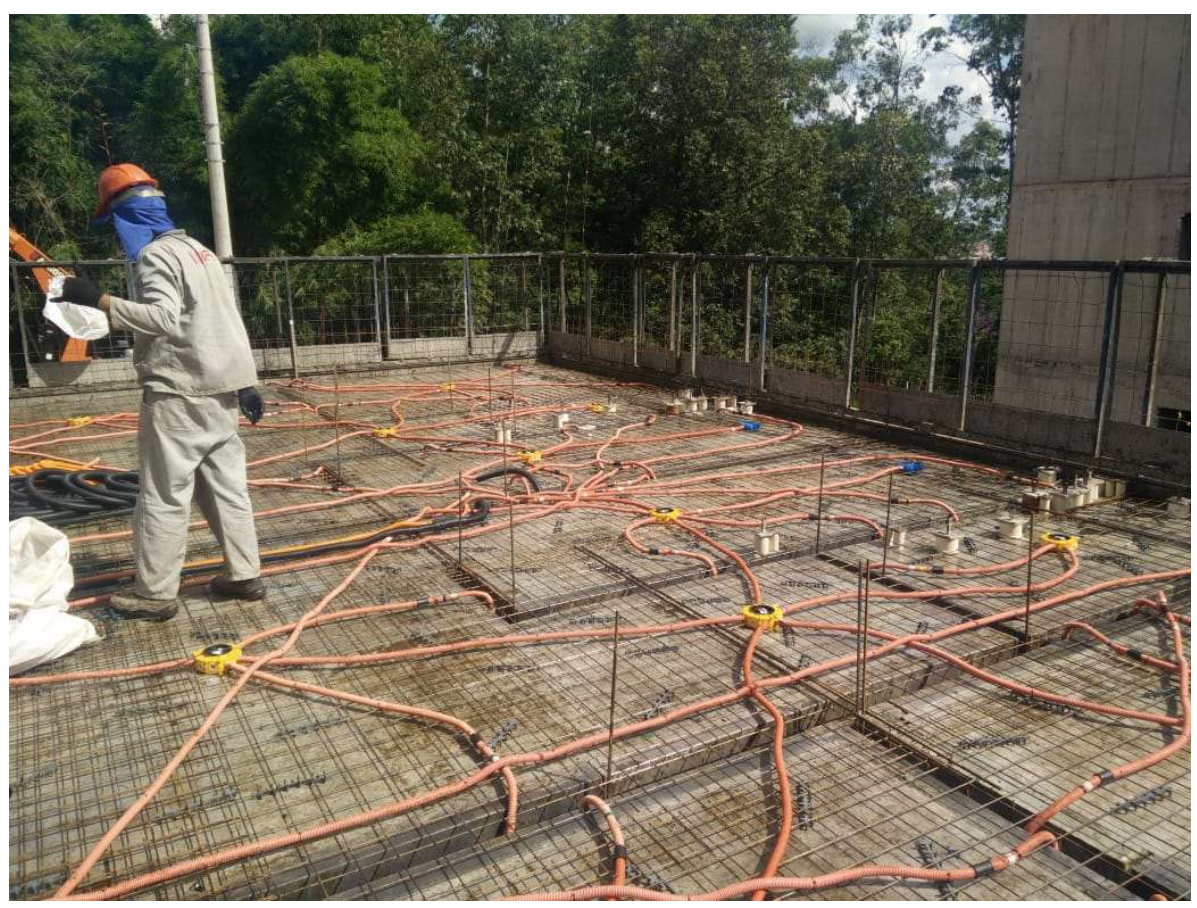

Fonte: Arquivo pessoal. 
Tabela 2.1 - Sistema construtivo de paredes de concreto moldadas no local: vantagens e desvantagens. \begin{tabular}{l}
\hline Vantagens \\
\hline Racionalização da produção, com alta \\
produtividade, baixo índice de perdas e mão-de- \\
obra reduzida; \\
Sequência definida de tarefas: locação, montagem \\
das fôrmas, posicionamento das instalações e \\
fixação dos negativos das esquadrias com \\
possibilidade dos batentes na própria fôrma, \\
resultando na redução do custo global da obra; \\
Aumento da qualidade tanto nos serviços de \\
execução quanto no acabamento superficial;
\end{tabular}

As fôrmas são reutilizáveis e cada conjunto produz os painéis de vedação de uma habitação em 24 horas, podendo incluir a laje na cobertura;

Possibilidade de a vedação exercer função estrutural, onde as paredes são adotadas para distribuir o carregamento;

Uniformidade da parede que permite a utilização de revestimento de pequena espessura, ou mesmo sua eliminação, sem necessidade de regularização antes da aplicação da pintura;

O consumo de mão-de-obra é reduzido quando comparado ao processo construtivo tradicional;

Existe uma sequência ordenada de trabalho que permite uma simplificação das tarefas;

O emprego desse sistema construtivo exige organização e maior planejamento do processo de construção. As soluções devem ser tomadas previamente à execução, evitando possíveis problemas em obra;

Proporciona o aumento da área útil da habitação, quando comparado aos sistemas convencionais com paredes com espessura acima de $15 \mathrm{~cm}$, pois os painéis de concreto usualmente apresentam espessura final entre $8 \mathrm{~cm}$ e $12 \mathrm{~cm}$.

\section{Desvantagens}

Elevado custo das fôrmas que deve ser diluído em diversas utilizações. Essa necessidade de alta reutilização ocorre apenas quando se tem uma demanda constante e uma tipologia habitacional definida;

Há, na maioria dos casos, necessidade de equipamentos de grande porte para o emprego das fôrmas metálicas, que são geralmente pesadas e de grandes dimensões;

$\mathrm{Na}$ execução com paredes monolíticas moldadas no local, algumas limitações podem ser apontadas em relação ao projeto devido, principalmente, à função estrutural;

No emprego de fôrmas tipo túnel e mesa/parede, há restrições quanto ao emprego de lajes com diferentes níveis, devido ao deslocamento de fôrmas em cada andar nos ciclos da produção;

No emprego de fôrmas tipo túnel e mesa/parede, há paredes com função de vedação que não são determinadas pelo método construtivo e quando ocorre o emprego de alvenaria de blocos, estas não conseguem acompanhar a velocidade com que são executadas as paredes estruturais;

As manifestações patológicas, principalmente as fissuras, a umidade e o desempenho insatisfatório decorrentes do inadequado emprego do sistema no passado contribuem para a pouca utilização do mesmo no presente. 
Figura 2.2 - Amarração de telas das paredes.

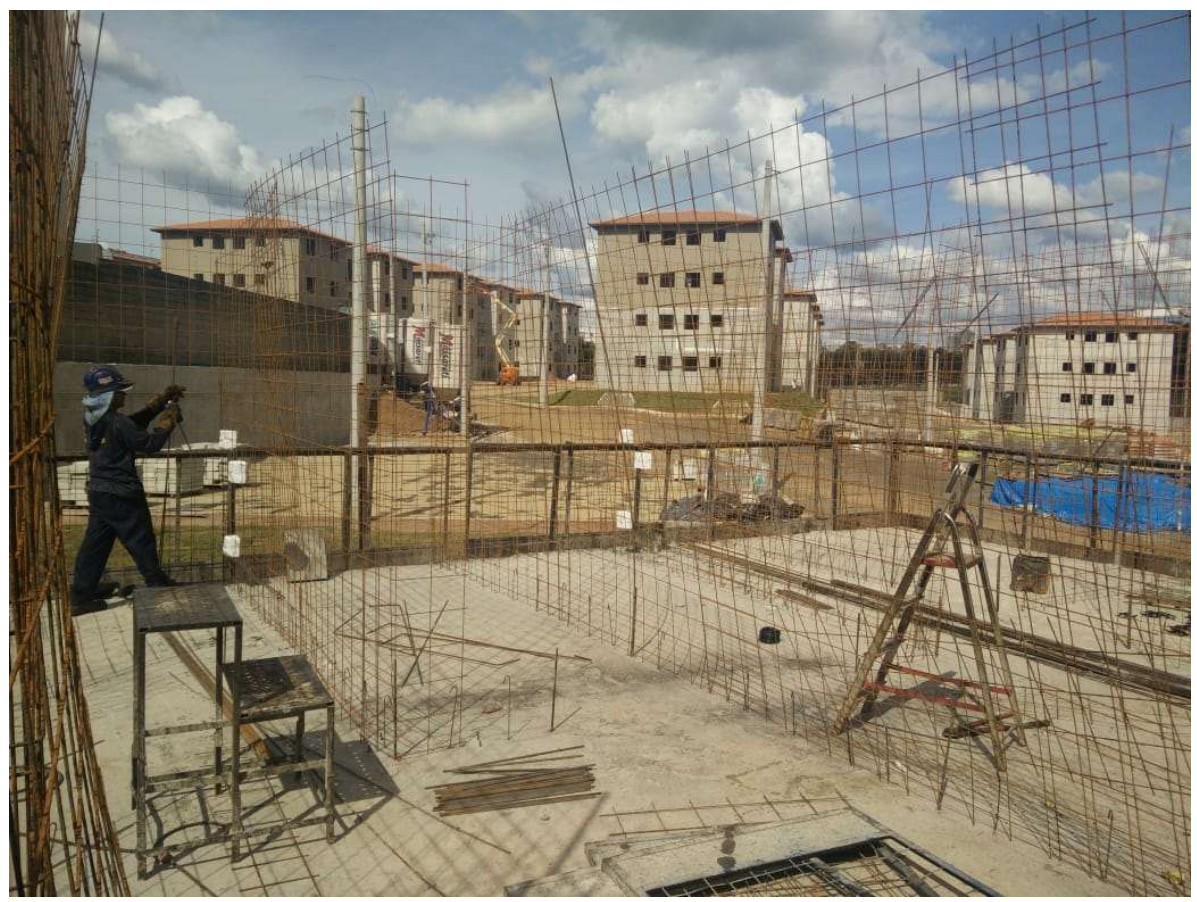

Fonte: Arquivo pessoal.

Figura 2.3 - Preparação de formas para concretagem de lance superior da escada.

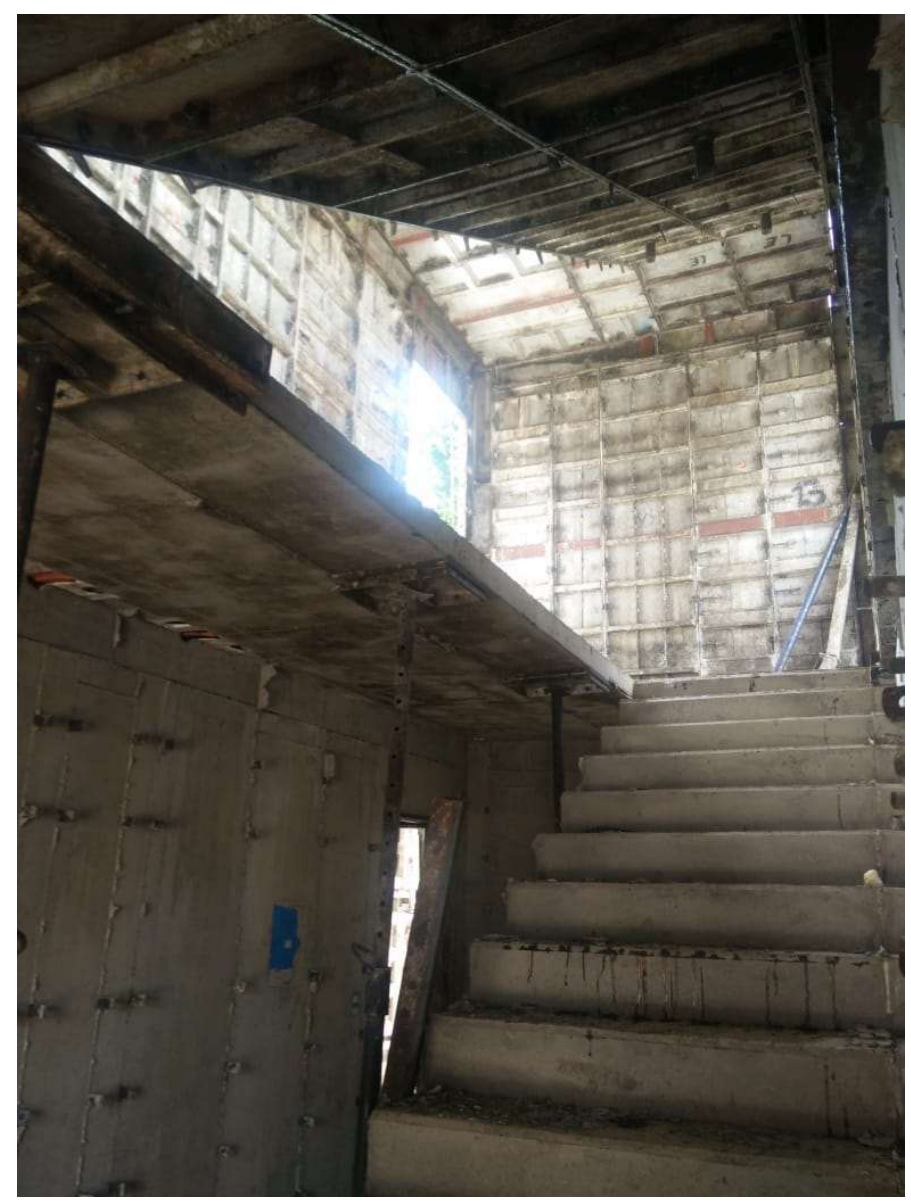

Fonte: Arquivo pessoal. 
Figura 2.4 - Estrutura concretada e preparação para concretagem do próximo pavimento.

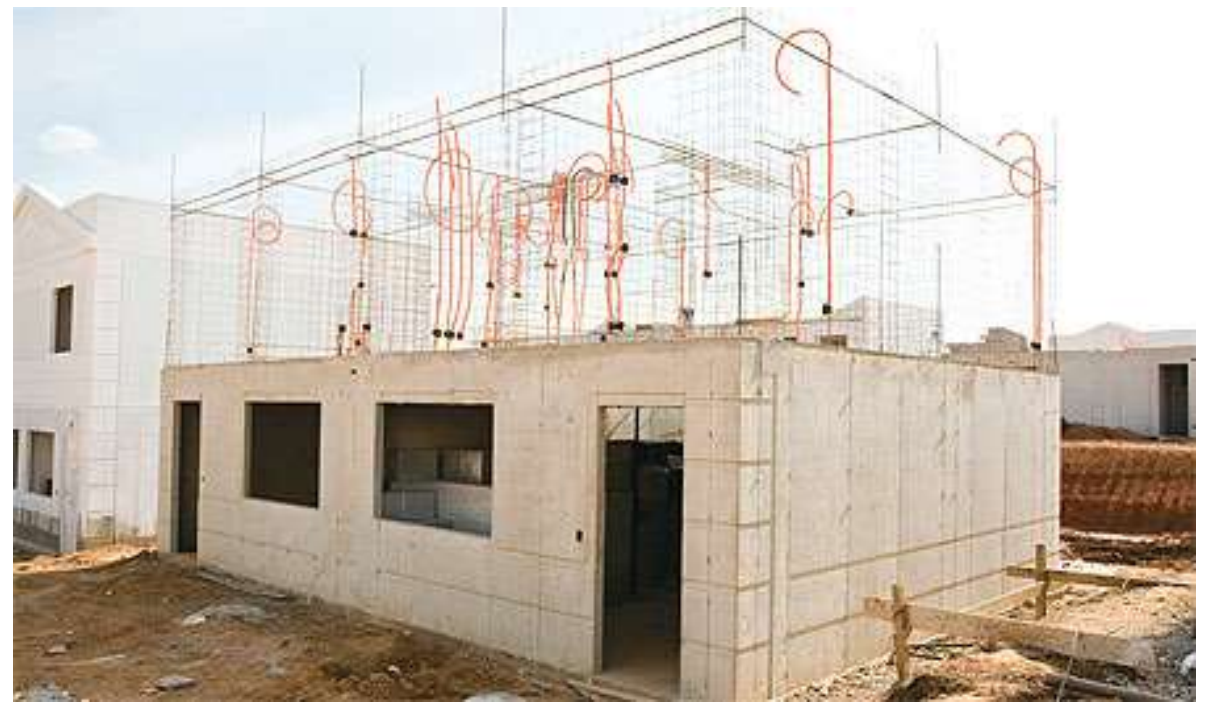

Fonte: Faria (2009).

Por se tratarem de elementos muito esbeltos, com telas soldadas em larguras estreitas, instalações embutidas e recortes nas paredes, deve-se ter cuidado especial na etapa de concretagem das paredes (COMUNIDADE DA CONSTRUÇÃO, 2009/2010).

O concreto utilizado deve apresentar fluidez e coesão elevada para o adequado preenchimento das fôrmas sem que haja segregação dos componentes da mistura. A qualidade do concreto influencia ainda diretamente no tempo de execução da estrutura, pois as resistências iniciais obtidas determinam o tempo necessário para a desforma, limitando a continuação do ciclo de moldagem (SANTOS, 2012).

Atualmente, a NBR 16055:2012 recomenda a utilização de concreto autoadensável para a execução das paredes de concreto moldadas no local, de forma que sejam evitados os possíveis problemas relacionados à concretagem (ABNT, 2012b).

\subsection{Concreto autoadensável}

O CAA foi inicialmente desenvolvido no Japão em 1988 com o objetivo de se obter estruturas de concreto mais duráveis. O contexto que envolveu a criação desse tipo de concreto teve início em 1983, período em que o Japão enfrentou uma diminuição da mão-de-obra qualificada na construção civil com consequente diminuição da qualidade e durabilidade das estruturas de concreto. Assim, de forma a se conseguir construções duráveis independentemente da mão-de-obra envolvida, foi proposto um concreto que se compactasse em todos os cantos 
das fôrmas por ação apenas de seu peso próprio sem a necessidade de vibração (OKAMURA; OUCHI, 2003).

O efeito de autoadensabilidade por parte do concreto deve ser alcançado sempre com o cuidado de produzir uma mistura que apresente simultaneamente habilidade de preenchimento, habilidade passante e resistência à segregação quando do estado fresco (ABNT, 2017a).

A habilidade de preenchimento representa a capacidade do concreto autoadensável fluir dentro da fôrma e preencher todos os espaços, de maneira que obstáculos ou formas complexas não interfiram no fluxo. Os mecanismos que governam essa propriedade são alta fluidez e coesão da mistura (GOMES; BARROS, 2009; ABNT, 2017a).

Segundo a NBR 15823-1:2017, a habilidade de passagem é a capacidade do concreto autoadensável fluir dentro da fôrma, passando entre os embutidos, sem obstrução do fluxo ou segregação (ABNT, 2017a). Gomes e Barros (2009) afirmam que os mecanismos que governam essa propriedade são as características dos agregados e as viscosidades da pasta e da argamassa.

Já a resistência à segregação é definida como a capacidade do concreto de permanecer com sua composição homogênea durante as etapas de transporte, lançamento e acabamento (ABNT, 2017a). Conforme Gomes e Barros (2009), a viscosidade e a coesão da mistura comandam essa resistência.

A produção do CAA, em termos de materiais, é mais cara em relação à do concreto convencional e é difícil mantê-lo na consistência desejada durante um longo período de tempo. No entanto, o tempo de construção é mais curto, é possível a concretagem de elementos com altas taxas de armadura, diminuição da mão-de-obra na operação de moldagem, o produto final apresenta bom acabamento superficial e ainda se percebe redução do ruído proveniente de vibradores e fôrmas vibratórias utilizados em concretos convencionais (KOSMATKA; KERKHOFF; PANARESE, 2002; EL DEBS, 2017).

Apesar disso, Mehta e Monteiro (2014) afirmam que concreteiras ainda relutam em utilizar CAA em função do alto custo de produção e de requisitos adicionais para controle de qualidade que são necessários ao se usar aditivos na composição da mistura. EFNARC (2002), por outro lado, justifica a eficiência econômica do CAA a partir das vantagens propiciadas com sua utilização. Além das já apresentadas, citam-se o lançamento facilitado, durabilidade melhorada, maior liberdade de projeto, seções de concreto mais esbeltas e ambiente de trabalho mais seguro. 


\subsubsection{Comportamento no estado fresco}

Em termos reológicos, o concreto pode ser entendido como uma concentração de partículas sólidas em suspensão (agregados) em um líquido viscoso (pasta de cimento) (CASTRO, 2007). Para definir o comportamento reológico de um fluido, utiliza-se um diagrama que representa a tensão de cisalhamento aplicada em função do gradiente de velocidade de deformação (ZERBINO et al., 2006).

Segundo Castro (2007), o concreto convencional no estado fresco se comporta como um fluido binghamiano, ou seja, é um fluido com comportamento de um sólido elástico rígido até que seja excedida uma tensão mínima (tensão de escoamento). Após esse limite, a relação entre tensão de cisalhamento e taxa de cisalhamento torna-se linear. Em se tratando de concreto de alta resistência (CAR), Zerbino et al. (2006) afirmam que o material apresenta maior viscosidade plástica que um concreto convencional, principalmente em função da menor relação água/cimento, e também apresenta menor limite de escoamento. Os mesmos autores afirmam que um CAA, por outro lado, possui tensão de escoamento praticamente nula e viscosidade suficiente para garantir o transporte, o preenchimento e o adensamento do concreto sem ocorrer segregação. A Figura 2.5 apresenta uma comparação esquemática entre as curvas de fluxo características de um concreto autoadensável, um concreto convencional e um concreto de alta resistência.

Figura 2.5 - Curvas de fluxo características de um concreto autoadensável (CAA), um concreto convencional (CC) e um concreto de alta resistência (CAR).

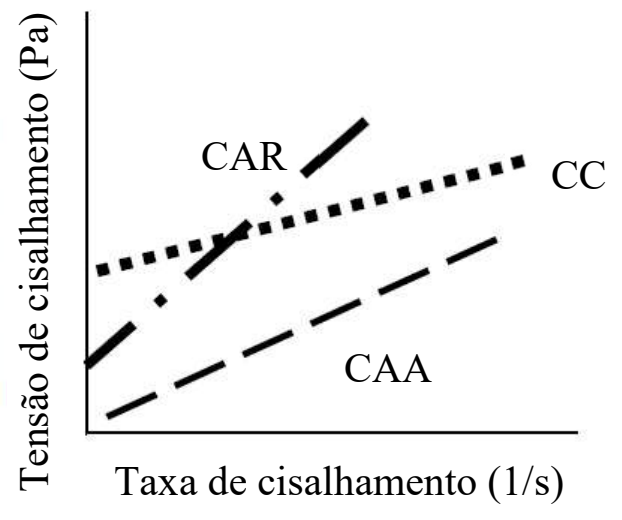

Fonte: Adaptado de Zerbino et al. (2006).

Em concretos autoadensáveis, a fluidez, a habilidade passante e a resistência à segregação são fundamentais. Porém, em geral, as duas primeiras características são opostas à última. Dessa forma, para que se consiga um CAA, é necessária uma combinação adequada 
entre a tensão de escoamento e a viscosidade plástica de forma que seja possível alcançar uma maior trabalhabilidade sem risco de segregação (ZERBINO et al., 2006).

\subsubsection{Materiais constituintes}

Em termos de composição, o CAA é um concreto que apresenta os mesmos materiais de um concreto convencional, com algumas mudanças nas características de alguns componentes, acrescido de aditivos e adições (GOMES; BARROS, 2009). Mehta e Monteiro (2014) esclarecem que além de agregado miúdo, agregado graúdo e cimento Portland, os ingredientes necessários para a fabricação de CAA incluem ainda aditivos superplastificantes e/ou aditivos modificadores de viscosidade, associados com a incorporação de adições minerais de partículas finas.

Gomes e Barros (2009) afirmam que em razão da grande quantidade de aditivos e adições presentes no mercado e ainda pelas várias combinações que podem ser utilizadas na obtenção das misturas de CAA, a etapa de seleção dos materiais para o CAA é a mais trabalhosa.

$\mathrm{Na}$ sequência estão apresentados os componentes de um CAA, com breve descrição fornecida por Gomes e Barros (2009).

- Cimento: podem ser utilizados todos os tipos de cimento Portland, de acordo com as especificações de normas técnicas locais;

- Agregados miúdo e graúdo: devem ser respeitadas as mesmas exigências normativas impostas ao concreto convencional;

- Aditivos superplastificantes: são responsáveis por aumentar a fluidez do concreto, sendo definidos como agentes redutores de água;

- Aditivos modificadores de viscosidade: aumentam a coesão da mistura, melhorando a estabilidade e a mobilidade do concreto, além de reduzir a sedimentação;

- Adições minerais: são materiais finamente moídos, incorporados ao concreto com a finalidade de obter características específicas;

- Água: utilizada basicamente com quatro diferentes funções, sendo uma para hidratação do cimento, uma para absorção e adsorção dos agregados e materiais finos, uma para preencher a porosidade do esqueleto granular e uma última para garantir a fluidez do concreto. 
A quantidade de cimento na produção do CAA varia em torno de 200 a $450 \mathrm{~kg} / \mathrm{m}^{3}$, a depender do uso conjunto com adições. O volume de agregado miúdo varia normalmente entre $40 \%$ e $50 \%$ do volume de argamassa, com proporções aproximadas de 710 a $900 \mathrm{~kg} / \mathrm{m}^{3}$. Já o volume de agregado graúdo varia de maneira geral entre $28 \%$ e $35 \%$ do volume de concreto, com proporções aproximadas de $750 \mathrm{~kg} / \mathrm{m}^{3}$ a $920 \mathrm{~kg} / \mathrm{m}^{3}$ (GOMES; BARROS, 2009).

Segundo NBR 15823-1:2017, os aditivos devem ser adicionados em quantidade não maior que 5\% da massa de material cimentício contida no concreto (ABNT, 2017a). As adições devem atender aos requisitos de normas específicas:

- Sílica ativa: NBR 13956-1:2012 - Sílica ativa para uso com cimento Portland em concreto, argamassa e pasta - Parte 1: Requisitos (ABNT, 2012a);

- Metacaulim: NBR 15894-1:2010 - Metacaulim para uso com cimento Portland em concreto, argamassa e pasta - Parte 1: Requisitos (ABNT, 2010b);

- Outros materiais pozolânicos: NBR 12653:2014 - Materiais pozolânicos - Requisitos (ABNT, 2014b).

Geralmente, quanto maior a fluidez requerida da mistura de CAA, maior a quantidade de material fino necessário para produzir uma mistura estável (KOSMATKA; KERKHOFF; PANARESE, 2002).

\subsubsection{Métodos de dosagem}

Quando se trata da dosagem do concreto, EFNARC (2005) aponta que não existe um método padrão para dosagem de concretos autoadensáveis. Por essa razão, muitas instituições acadêmicas e empresas envolvidas diretamente com a produção de CAA desenvolveram seus próprios métodos de dosagem de mistura.

São muitas as metodologias de dosagem que podem ser consideradas na elaboração dos traços de CAA. Shi et al. (2015) destacam que os métodos de dosagem de CAA podem ser classificados em cinco categorias: métodos de dosagem empíricos; do empacotamento de agregados; de resistência à compressão; e métodos baseados em modelos estatísticos e na reologia da pasta. Alguns dos métodos de dosagem já publicados estão apresentados na sequência.

- Método de Okamura e Ozawa: consiste em método de dosagem empírico no qual se fixam os agregados graúdo e miúdo para, em seguida, obter o efeito de autoadensabilidade 
ao ajustar a dosagem de superplastificante e a relação água/materiais finos (OKAMURA; OZAWA, 1995; GHAZI; AL JADIRI, 2010; SHI et al., 2015).

- Método de Petersson, Billberg e Van (1996): é um método de dosagem com base no empacotamento dos agregados no qual se determina um esqueleto granular e um mínimo volume de pasta que garantam a autoadensabilidade ao concreto (PETERSSON; BILLBERG; VAN, 1996³ apud GOMES; BARROS, 2009; SHI et al., 2015).

- Método de Su, Hsu e Chai (2001): consiste também em um método baseado no empacotamento de partículas, em que a quantidade de agregados necessários é determinada e a pasta preenche os vazios entre as partículas de agregados para garantir que o concreto obtido tenha fluidez, capacidade de autocompactação e outras propriedades desejadas para o CAA (SU; HSU; CHAI, 2001).

- Método de Saak, Jennings e Shah (2001): o método, baseado na reologia da pasta, sugere que a segregação do agregado é comandada pela tensão de escoamento, viscosidade e densidade da pasta de cimento. O conceito de uma zona reológica de autofluidez para o concreto é introduzido de forma que se evita a segregação dos agregados mantendo alta trabalhabilidade para o concreto (SAAK; JENNINGS; SHAH, 2001).

- Método EFNARC (2002): nesse método a composição da mistura deve satisfazer todos os critérios de desempenho para o concreto tanto no estado fresco (habilidade passante, habilidade de preenchimento e resistência à segregação) quanto no estado endurecido (EFNARC, 2002).

- Método de Gomes, Gettu e Agulló: o procedimento em questão pressupõe que o CAA pode ser obtido otimizando separadamente a composição da pasta e do esqueleto granular, e depois o conteúdo de pasta do concreto para obter a composição final (GOMES; GETTU; AGULLÓ, 2003; GOMES; BARROS, 2009).

- Método de Alencar e Helene: considera que a otimização dos materiais é obtida com um aumento gradual do teor de argamassa e da quantidade de aditivo, associada a uma maior substituição de materiais com maior área superficial (ALENCAR, 2008).

${ }^{3}$ PETERSSON, O.; BILLBERG, P.; VAN, B. K. A model for self-compacting concrete. In: International Rilem Conference on Production Methods and Workability of Concrete. 1996. p. 483-492. 


\subsection{Ar incorporado}

Mehta e Monteiro (2014) apresentam que a pasta de cimento hidratada contém diferentes tipos de vazios que exercem importante influência nas propriedades do concreto. Dentre eles citam-se os vazios capilares, os vazios de ar aprisionado e ainda os vazios de ar incorporado propositalmente.

Os vazios capilares representam o espaço não preenchido pelos componentes sólidos da pasta de cimento hidratada e apresentam formato bastante irregular. Em pastas de cimento bem hidratadas e com baixa relação água/cimento $(\mathrm{a} / \mathrm{c})$, os vazios capilares podem variar de 10 a $50 \mathrm{~nm}$, enquanto que em pastas de elevada relação a/c, os vazios capilares podem ser tão grandes quanto 3 a $5 \mu \mathrm{m}$. Os vazios capilares maiores que $50 \mathrm{~nm}$ são chamados de macroporos com grande influência na determinação das características de resistência e permeabilidade do material. Já os vazios menores que $50 \mathrm{~nm}$, conhecidos como microporos, desempenham um papel importante na fluência e na retração por secagem (KOSMATKA; KERKHOFF; PANARESE, 2002; MEHTA; MONTEIRO, 2014).

Os vazios de ar aprisionado ocorrem em todos os concretos como resultado da mistura, manuseio e concretagem e são em grande parte uma função das características dos agregados. Os vazios de ar aprisionado usualmente apresentam tamanho de $1000 \mu \mathrm{m}(1 \mathrm{~mm})$ ou maior, podendo ser tão grandes quanto 3 mm (KOSMATKA; KERKHOFF; PANARESE, 2002; MEHTA; MONTEIRO, 2014).

Outro tipo de vazio pode ser obtido com a utilização de aditivo incorporador de ar. Kosmatka, Kerkhoff e Panarese (2002) destacam que o desenvolvimento do aditivo incorporador de ar ocorreu em meados da década de 1930 e representou um dos maiores avanços na tecnologia do concreto. Mehta e Monteiro (2014), porém, ressaltam que a utilização desses aditivos não estava muito bem estabelecida antes da década de 1950, situação que mudou com o avanço da tecnologia.

Esses aditivos apresentam estrutura química típica que consiste em cadeia hidrocarbônica apolar com um grupo polar aniônico em sua extremidade, o que faz com que vazios de ar sejam incorporados e estabilizados quando da sua adição ao concreto (MEHTA; MONTEIRO, 2014). Kosmatka, Kerkhoff e Panarese (2002) afirmam ainda que esses aditivos aumentam a incorporação de bolhas de vários tamanhos ao reduzir a tensão superficial da água de amassamento.

Quando da adição de incorporador de ar na mistura de concreto, Mehta e Monteiro (2014) afirmam que, na interface ar-água, os grupos polares são orientados para a fase de água 
baixando a tensão superficial, promovendo a formação de bolhas e neutralizando a tendência de aglutinação de bolhas dispersas. $\mathrm{Na}$ interface sólido-água, os grupos polares ficam ligados ao sólido com os grupos apolares orientados para a água, tornando a superfície do cimento hidrofóbica, de maneira que o ar possa deslocar a água e permanecer ligado às partículas sólidas no formato de bolhas. A Figura 2.6 ilustra esse mecanismo de ação.

Figura 2.6 - Mecanismo de ação do aditivo incorporador de ar.

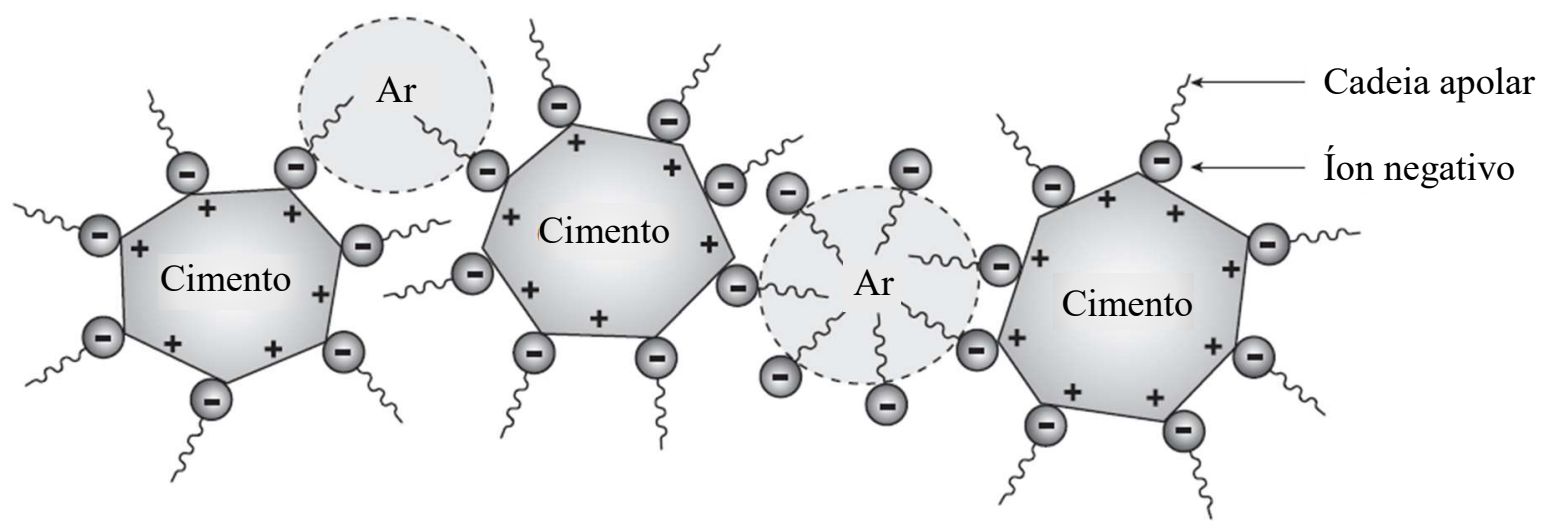

Fonte: Adaptado de Mehta e Monteiro (2014).

As bolhas de ar incorporadas intencionalmente ao concreto são de tamanho extremamente pequeno, entre 10 a $1000 \mu \mathrm{m}$ de diâmetro, sendo que a maioria delas em concreto convencional tem entre 10 e $100 \mu \mathrm{m}$ de diâmetro (KOSMATKA; KERKHOFF; PANARESE, 2002).

A Figura 2.7 apresenta uma comparação entre as dimensões médias de cada tipo de vazio presente em uma pasta de cimento hidratada.

Figura 2.7 - Escala dimensional de sólidos e poros em uma pasta de cimento hidratada.

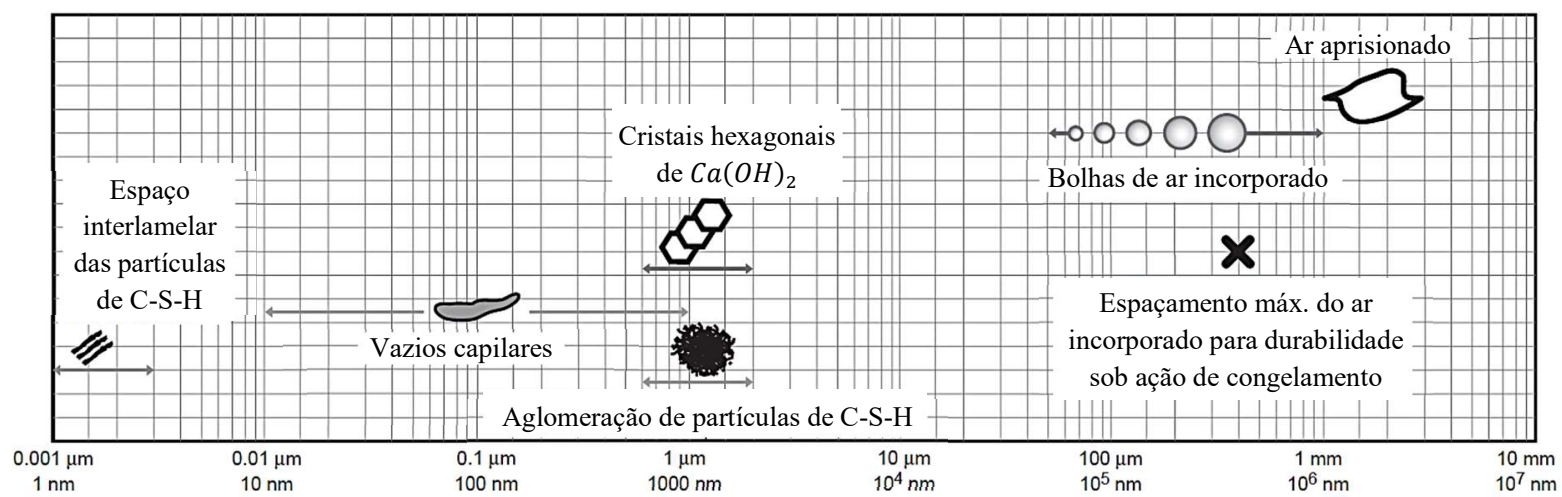

Fonte: Adaptado de Mehta e Monteiro (2014). 
A incorporação e estabilização de bolhas de ar representam um sistema extremamente complexo. Todo componente em misturas de concreto, incluindo cimento Portland, agregados, água e aditivos afetam o sistema de vazios em graus variados (DU; FOLLIARD, 2005).

Os aditivos incorporadores de ar são muito eficientes quando utilizados com o objetivo de aumentar a resistência do concreto frente aos efeitos do congelamento. Isso acontece porque o ar incorporado cria fronteiras de fuga na matriz da pasta de cimento, reduzindo a pressão hidráulica causada pelo aumento de volume que acompanha o congelamento da água capilar (MEHTA; MONTEIRO, 2014).

Não é o ar total, mas o espaço vazio da ordem de 0,1 a $0,2 \mathrm{~mm}$ do concreto endurecido que é necessário para proteção de concreto contra danos causados pelo congelamento. Ao adicionar uma pequena quantidade de aditivo incorporador ar na pasta de cimento é possível incorporar bolhas de 0,05 a $1 \mathrm{~mm}$. No entanto, para determinados volumes de ar, o comportamento do concreto endurecido vai depender não só do tamanho das bolhas, mas também do número e do espaçamento entre elas (MEHTA; MONTEIRO, 2014).

Du e Folliard (2005) afirmam que as bolhas de ar em concreto fresco são inerentemente instáveis. A interface entre o ar disperso e a matriz da pasta contém energia superficial livre e a tendência termodinâmica é reduzir a área superficial coincidente. Dessa forma, as bolhas de ar têm uma vida útil. Se a preparação do concreto é muito demorada, podese esperar a falta de bolhas de ar pequenas no concreto endurecido, interferindo diretamente, por exemplo, no grau de proteção contra a ação do congelamento.

Quando o concreto é altamente fluido, as bolhas de ar podem se mover mais livremente, elevando o índice de ruptura de bolhas. Uma mistura de CAA com maior viscosidade pode evitar que as bolhas se rompam criando um "efeito de almofada" para que os vazios do ar permaneçam não sendo afetados pela mistura e outros distúrbios (BARFIELD; GHAFOORI, 2012).

O teor de ar a ser incorporado depende do uso do concreto produzido. O ACI 318 (2008), por exemplo, define diferentes teores de ar em função do tamanho máximo do agregado utilizado e da categoria de exposição do exterior do concreto aos ciclos de congelamento e degelo (Tabela 2.2). 
Tabela 2.2 - Teor de ar total para concreto exposto a ciclos de congelamento e degelo.

\begin{tabular}{ccc}
\hline \multirow{2}{*}{$\begin{array}{c}\text { Tamanho máximo do } \\
\text { agregado }(\mathbf{m m})\end{array}$} & \multicolumn{2}{c}{ Teor de ar (\%) } \\
\cline { 2 - 3 } & Classe de exposição F1 & Classes de exposição F2 e F3 \\
\hline 9,5 & 6 & 7,5 \\
\hline 12,5 & 5,5 & 7 \\
\hline 19 & 5 & 6 \\
\hline 25 & 4,5 & 5,5 \\
\hline 37,5 & 4,5 & 5 \\
\hline 50 & 4 & 4,5 \\
\hline 75 & 3,5 & \\
\hline
\end{tabular}

Onde:

F1 representa a classe na qual o concreto está exposto a ciclos de congelamento e degelo e ainda ocasionalmente exposto à umidade;

F2 indica que o concreto está exposto a ciclos de congelamento e degelo e continuamente exposto à umidade;

F3 é a classe na qual o concreto está exposto a ciclos de congelamento e degelo, continuamente exposto à umidade e ainda exposto a químicos utilizados no degelo.

Fonte: Adaptado de ACI 318 (2008).

Voltando à realidade brasileira, a Comunidade da Construção (2007/2008) apresenta que concretos com teor de ar de até $9 \%$ são definidos como de alto teor de ar incorporado. Afirma ainda que concretos com essa composição eram usualmente utilizados em residências de até 2 pavimentos quando considerados com resistência à compressão mínima de $6 \mathrm{MPa}$.

Em termos de porosidade da matriz de pasta de cimento, a relação água/cimento aparece, na maioria das vezes, como o fator determinante. Contudo, quando os vazios de ar são incorporados no sistema, seja como resultado de compactação inadequada ou pelo uso de aditivo incorporador de ar, eles também têm o efeito de aumentar a porosidade e diminuir a resistência do sistema. De maneira geral, para uma dada relação água/cimento, um concreto com ar incorporado apresentará resistência à compressão menor do que um concreto sem essa incorporação (MEHTA; MONTEIRO, 2014). Esse efeito está representado na Figura 2.8a.

Mehta e Monteiro (2014) apresentam que a extensão da perda de resistência como resultado do ar incorporado depende não apenas da relação água/cimento, mas também da quantidade de cimento. Como pode ser observado na Figura 2.8b, para uma relação a/c fixa, concretos com alto consumo de cimento tendem a sofrer perdas de resistência mais elevadas quando da incorporação de ar do que concretos com baixo consumo de cimento. Em casos mais extremos, com consumo de cimento muito baixo, o concreto chega a apresentar ganho de resistência com a incorporação de ar em função do aumento de trabalhabilidade proporcionado. 
Figura 2.8 - Influência da relação a/c, ar incorporado e quantidade de cimento na resistência do concreto.

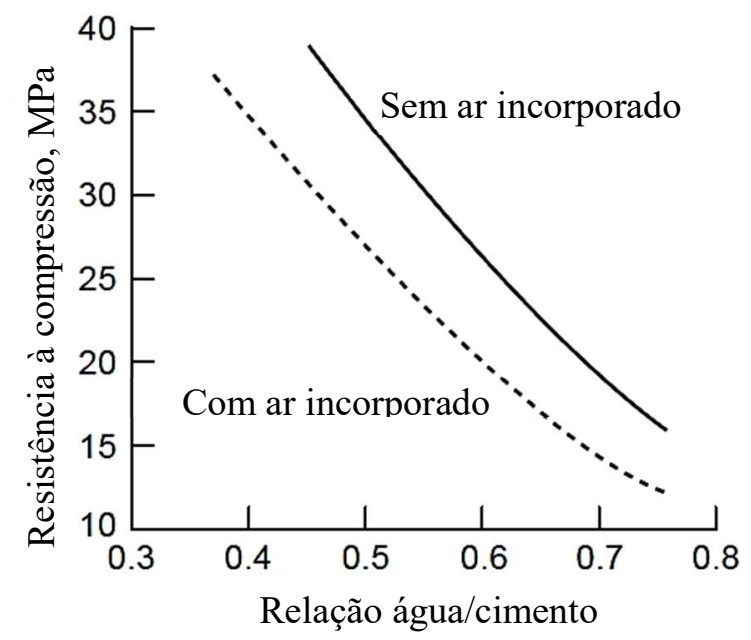

(a)

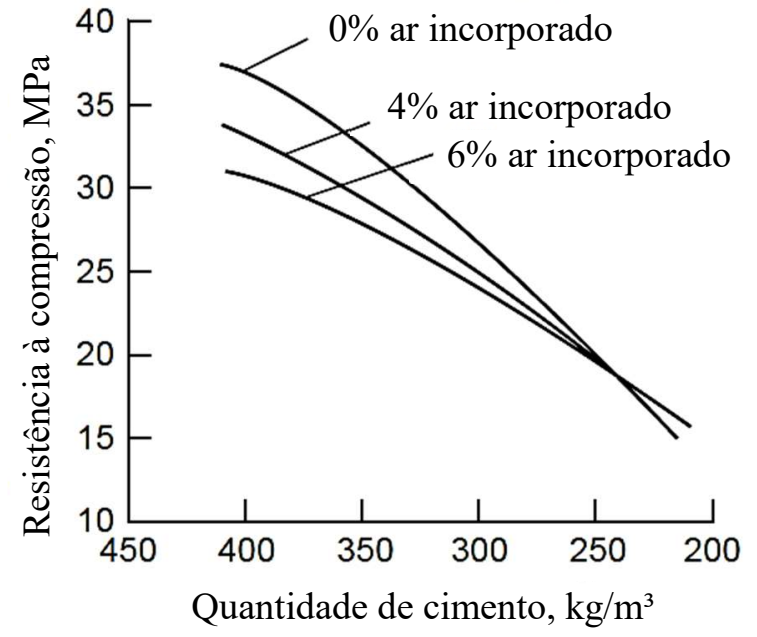

(b)

Fonte: Adaptado de Mehta e Monteiro (2014).

São vários os efeitos observados no concreto com o aumento do teor de ar incorporado. Kosmatka, Kerkhoff e Panarese (2002) apresentam alguns desses efeitos observados em diversas propriedades do concreto no estado fresco e também no estado endurecido (Tabela 2.3).

Em se tratando do uso conjunto de aditivos incorporador de ar e superplastificante, Sovannsathya et al. (2017) afirmam que quando esses aditivos são adicionados ao mesmo tempo à mistura, a interação de ambos pode interferir na eficácia um do outro.

Attachaiyawuth et al. (2016) apresentam um estudo no qual o foco da incorporação de ar em CAA é produzir um concreto para utilização em estruturas comuns que requerem resistências da ordem de $30 \mathrm{MPa}$. No artigo em questão foi retratado o desenvolvimento de um método de mistura denominado water-dividing mixing method, no qual inicialmente o cimento é misturado com os agregados por 30 segundos. Na sequência, metade da água é adicionada em conjunto com o superplastificante e os materiais são misturados por mais 60 segundos. Por fim, o restante da água e o aditivo incorporador de ar são adicionados, e mistura-se tudo por mais 60 segundos. Os autores afirmam que com esse método é possível aumentar a fluidez da pasta ao se reduzir a fricção da mesma. 
Tabela 2.3 - Efeitos da incorporação de ar nas propriedades do concreto.

\begin{tabular}{|c|c|}
\hline Propriedades & Efeitos \\
\hline Abrasão & $\begin{array}{c}\text { Pequeno efeito; aumento na resistência à compressão causa } \\
\text { aumento na resistência à abrasão }\end{array}$ \\
\hline Absorção de água & Pequeno efeito \\
\hline Acabamento & Dificultado devido ao aumento da coesão (viscosidade) \\
\hline Aderência ao aço & Reduz \\
\hline Calor de hidratação & Sem efeito significante \\
\hline Calor específico & Sem efeito \\
\hline Condutividade térmica & $\begin{array}{l}\text { Reduz de } 1 \% \text { a } 3 \% \text { a cada aumento de } 1 \% \text { no teor de ar } \\
\text { incorporado }\end{array}$ \\
\hline $\begin{array}{l}\text { Demanda de água para } \\
\text { um concreto fresco de } \\
\text { abatimento equivalente }\end{array}$ & $\begin{array}{c}\text { Reduz aproximadamente } 3 \text { a } 6 \mathrm{~kg} / \mathrm{m}^{3} \text { a cada aumento de } 1 \% \text { no } \\
\text { teor de ar incorporado }\end{array}$ \\
\hline Densidade & Reduz com aumento no teor de ar incorporado \\
\hline Delaminação & Reduz significativamente \\
\hline $\begin{array}{l}\text { Descamação por ciclos de } \\
\text { congelamento e degelo }\end{array}$ & Reduz significativamente \\
\hline Difusividade térmica & $\begin{array}{l}\text { Reduz aproximadamente } 1,6 \% \text { a cada aumento de } 1 \% \text { no teor de } \\
\text { ar incorporado }\end{array}$ \\
\hline Abatimento (slump) & $\begin{array}{l}\text { Aumenta aproximadamente } 25 \mathrm{~mm} \text { a cada aumento de } 0,5 \% \text { a } \\
\qquad 1 \% \text { no teor de ar incorporado }\end{array}$ \\
\hline Estanqueidade & $\begin{array}{c}\text { Aumenta levemente; redução na relação a/c aumenta a } \\
\text { estanqueidade }\end{array}$ \\
\hline Exsudação & Reduz significativamente \\
\hline Fadiga & Pequeno efeito \\
\hline Fluência & Pequeno efeito \\
\hline $\begin{array}{l}\text { Módulo de elasticidade } \\
\text { estático }\end{array}$ & $\begin{array}{l}\text { Reduz aproximadamente } 720 \text { a } 1380 \mathrm{MPa} \text { a cada aumento de } \\
\qquad 1 \% \text { no teor de ar incorporado }\end{array}$ \\
\hline Permeabilidade & Pequeno efeito; redução na relação a/c reduz a permeabilidade \\
\hline Reação álcali-sílica & Expansão reduz com aumento do teor de ar incorporado \\
\hline Resistência à compressão & $\begin{array}{l}\text { Reduz aproximadamente } 2 \% \text { a } 6 \% \text { a cada aumento de } 1 \% \text { no } \\
\text { teor de ar incorporado. Misturas mais pobres em cimento podem } \\
\text { aumentar sua resistência à compressão com a incorporação de ar }\end{array}$ \\
\hline Resistência à flexão & $\begin{array}{c}\text { Reduz aproximadamente } 2 \% \text { a } 4 \% \% \text { a cada aumento de } 1 \% \text { no } \\
\text { teor de ar incorporado }\end{array}$ \\
\hline $\begin{array}{l}\text { Resistência ao } \\
\text { congelamento e degelo }\end{array}$ & Significativamente aumentada \\
\hline Resistência ao sulfato & Significativamente aumentada \\
\hline Retração por secagem & Pequeno efeito \\
\hline $\begin{array}{l}\text { Temperatura do concreto } \\
\text { fresco }\end{array}$ & Sem efeito \\
\hline Trabalhabilidade & Aumenta com aumento no teor de ar incorporado \\
\hline Viscosidade & Coesão aumentada; acabamento dificultado \\
\hline
\end{tabular}


Sovannsathya et al. (2017) também destacam que ao se adicionar os aditivos superplastificante e incorporador de ar em etapas separadas, é possível obter maior fluidez para uma mesma relação a/c. No ajuste do procedimento de mistura desse estudo, o aditivo superplastificante foi adicionado antes do incorporador de ar de forma que a argamassa se tornasse menos viscosa, minimizando a presença de bolhas de ar grosseiras (de maior dimensão).

Dessa forma, é importante levar em consideração as etapas de mistura dos materiais componentes do concreto aqui proposto na tentativa de evitar maiores problemas relacionados ao uso conjunto de aditivo superplastificante e aditivo incorporador de ar. 


\section{METODOLOGIA}

O presente trabalho desenvolveu seis diferentes traços de concreto autoadensável. Inicialmente, foram propostos dois traços de referência sem incorporação de ar (pretendendo-se obter classes de resistência C25 e C40) enquanto que os outros quatro foram uma variação dos dois originais, visando a incorporação de ar em teores de 9\% e 15\%. Portanto, inicialmente, foi necessária a definição do método de dosagem considerado para a determinação dos mesmos.

\subsection{Método de dosagem}

Dentre as metodologias de dosagem apresentadas, optou-se por utilizar neste trabalho aquela proposta por Gomes, Gettu e Agulló (2002; 2003) pelo fato de consistir em procedimento simples e apresentar bons resultados, como pode ser observado em Santos (2012). O método consiste basicamente na separação das fases do concreto - pasta de cimento e esqueleto granular dos agregados - com o objetivo de se fazer uma otimização individual para cada uma delas. Depois, a composição do concreto é definida a partir da determinação do teor ideal de pasta de cimento, em relação ao volume de concreto, determinando-se as propriedades de autoadensabilidade do concreto no estado fresco. A Figura 3.1 apresenta um fluxograma que tem por objetivo facilitar a interpretação conjunta de todas as etapas do método em questão.

\subsubsection{Seleção dos materiais}

O primeiro passo da metodologia de dosagem consiste na escolha dos materiais utilizados para a produção das misturas de concreto autoadensável. Os materiais escolhidos para compor os traços determinados nesta pesquisa estão apresentados na sequência.

- Cimento Portland composto com escória, com resistência à compressão mínima aos 28 dias de idade igual a $32 \mathrm{MPa}$ - CPII E 32;

- Areia natural de origem quartzosa com granulometria média e fina;

- Agregado graúdo com dimensão máxima característica de 9,5 mm, pelo fato de as paredes de concreto moldadas no local normalmente apresentarem pequena espessura; 
Figura 3.1 - Metodologia de dosagem empregada no estudo.

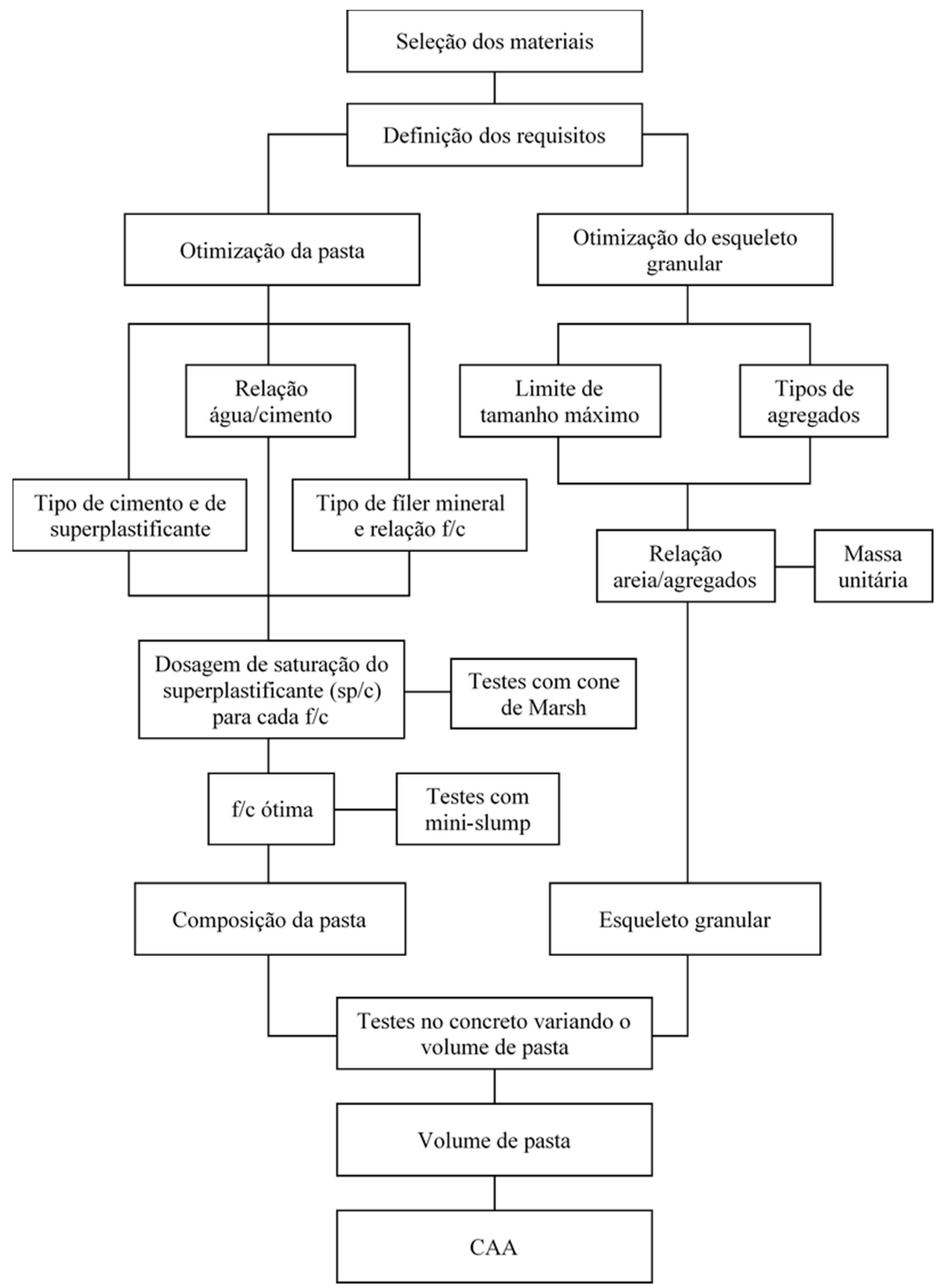

Fonte: Adaptado de Gomes e Barros (2009). 
- Sílica ativa derivada do processo de produção do silício metálico ou ferro silício;

- Fíler calcário de malha 325;

- Aditivo superplastificante à base de policarboxilatos para concreto com alto poder de redução de água ${ }^{4}$ - ADVA CAST 525;

- Aditivo incorporador de ar - DARAFILL EXP 300;

- Água proveniente da rede de abastecimento local.

Em termos de caracterização dos materiais selecionados, foram seguidos os seguintes procedimentos:

Cimento e sílica ativa:

- Ensaio de massa específica: NBR 16605:2017 - Cimento Portland e outros materiais em pó - Determinação da massa específica (ABNT, 2017g);

Agregados:

- Ensaio de absorção de água (agregado miúdo): NBR NM 30:2000 Agregado miúdo - Determinação da absorção de água (ABNT, 2000);

- Ensaio de massa específica (agregado miúdo): NBR NM 52:2009 Agregado miúdo - Determinação de massa específica e massa específica aparente (ABNT, 2009a);

- Ensaio de massa específica e absorção de água (agregado graúdo): $N B R N M$ 53:2009 - Agregado graúdo - determinação de massa específica, massa específica aparente e absorção de água (ABNT, 2009b);

- Composição granulométrica: NBR NM 248:2003 - Agregados Determinação da composição granulométrica (ABNT, 2003).

\subsubsection{Definição da composição da pasta}

Antes de apresentar as etapas evolvidas para definição da composição da pasta, vale destacar que, segundo fluxograma apresentado na Figura 3.1, a etapa seguinte à seleção dos materiais deveria ser a de definição dos requisitos para o concreto. Porém, como essa definição é feita com base nas propriedades de autoadensabilidade necessárias para que o concreto possa

\footnotetext{
${ }^{4}$ GCPAT. ADVA. Aditivo superplastificante (SP II) para concreto. Disponível em <https://gcpat.com.br/ptbr/solutions/products/adva-high-range-water-reducers/adva $>$ acesso em: 18 de março de 2019.
} 
ser utilizado em paredes de concreto moldadas no local, os requisitos para os concretos produzidos serão apresentados mais à frente, de acordo com os diferentes métodos de ensaio utilizados para caracterização dos CAAs quando do estado fresco.

Sendo assim, Gomes e Barros (2009) indicam que o próximo passo consiste na definição da composição da pasta. Isso deve ser feito a partir da quantidade de cimento $(C) \mathrm{e}$ da relação entre a massa dos demais componentes da pasta e a massa de cimento, ou seja, água $(a / c)$, superplastificante $(s p / c)$, sílica ativa $(s f / c)$ e fíler calcário $(f / c)$. As densidades são representadas pela letra $\rho$ acompanhada do índice referente a cada material. $\mathrm{O}$ volume da pasta $\left(V_{p}\right)$ é obtido a partir das seguintes relações:

$$
\begin{gathered}
V_{p}=\frac{C}{\rho_{c}}+\frac{P_{a}}{\rho_{a}}+\frac{P_{s f}}{\rho_{s f}}+\frac{P_{f}}{\rho_{f}}+\frac{P_{s p l}}{\rho_{s p}}-\frac{P_{a s p}}{\rho_{a}} \\
P_{s p l}=\frac{100 \cdot P_{s p}}{T_{s p}} \\
P_{a s p}=P_{s p} \cdot\left[\left(\frac{100}{T_{s p}}\right)-1\right] \\
P_{a c}=P_{a}-P_{a s p}
\end{gathered}
$$

Onde:

$P_{a}$ é a massa de água;

$P_{f}$ é a massa de fíler;

$P_{s p}$ é a massa de superplastificante sólido;

$P_{s p l}$ é a massa de superplastificante líquido;

$P_{a s p}$ é a massa de água contida no superplastificante;

$P_{a c}$ é a massa de água real adicionada corrigida ao se subtrair a água contida no superplastificante;

$T_{s p}$ é o teor de sólido do superplastificante.

Segundo Gomes e Barros (2009), inicialmente deve ser definido o volume de pasta em função do volume necessário para realização dos ensaios. Deve também ser fixada uma relação a/c em função das propriedades esperadas para o concreto. No caso deste trabalho, a resistência à compressão é o parâmetro a ser considerado para o CAA no estado endurecido, sendo necessária a escolha da relação a/c para as resistências aqui propostas (C25 e C40). 
Ghazi e Al Jadiri (2010) apresentam um método de dosagem no qual a mistura de CAA é desenvolvida com base em resistências à compressão específicas, o que permite determinar as máximas relações a/c para diferentes classes de resistência (Tabela 3.1).

Tabela 3.1 - Relações água/cimento para diferentes resistências à compressão de CAA.

\begin{tabular}{cccccccccccccc}
\hline$f_{c}(\mathrm{MPa})$ & 15 & 20 & 25 & 30 & 35 & 40 & 45 & 50 & 55 & 60 & 65 & 70 & 75 \\
$a / c$ & 0,8 & 0,7 & 0,62 & 0,55 & 0,48 & 0,43 & 0,38 & 0,36 & 0,34 & 0,33 & 0,31 & 0,29 & 0,27 \\
\hline \multicolumn{10}{c}{ Fonte: Ghazi e Al Jadiri (2010). }
\end{tabular}

A definição da relação a/c fica restrita ainda aos limites impostos pela $N B R$ 12655:2015 - Concreto de cimento Portland - Preparo, controle, recebimento e aceitação Procedimento, em função da classe de agressividade ambiental na qual a obra está inserida (ABNT, 2015b). As Tabelas 3.2 e 3.3 expõem o que está apresentado na norma em questão.

Tabela 3.2 - Classes de agressividade ambiental.

\begin{tabular}{|c|c|c|c|}
\hline $\begin{array}{c}\text { Classe de } \\
\text { agressividade } \\
\text { ambiental }\end{array}$ & Agressividade & $\begin{array}{l}\text { Classificação geral do } \\
\text { tipo de ambiente para } \\
\text { efeito de projeto }\end{array}$ & $\begin{array}{c}\text { Risco de } \\
\text { deterioração da } \\
\text { estrutura }\end{array}$ \\
\hline \multirow{2}{*}{$\mathrm{I}$} & \multirow{2}{*}{ Fraca } & Rural & \multirow{2}{*}{ Insignificante } \\
\hline & & Submersa & \\
\hline II & Moderada & Urbana & Pequeno \\
\hline \multirow{2}{*}{ III } & \multirow{2}{*}{ Forte } & Marinha & \multirow{2}{*}{ Grande } \\
\hline & & Industrial & \\
\hline \multirow{2}{*}{ IV } & \multirow{2}{*}{ Muito forte } & Industrial & \multirow{2}{*}{ Elevado } \\
\hline & & Respingos de Maré & \\
\hline
\end{tabular}

Fonte: NBR 12655:2015 (ABNT, 2015b).

Tabela 3.3 - Correspondência entre a classe de agressividade e a qualidade do concreto.

\begin{tabular}{cccccc}
\hline \multirow{2}{*}{ Concreto } & Tipo & \multicolumn{4}{c}{ Classe de agressividade } \\
\cline { 2 - 6 } & I & II & III & IV \\
\hline $\begin{array}{c}\text { Relação água/cimento } \\
\text { em massa }\end{array}$ & Concreto armado & $\leq 0,65$ & $\leq 0,60$ & $\leq 0,55$ & $\leq 0,45$ \\
\cline { 2 - 6 } & Concreto protendido & $\leq 0,60$ & $\leq 0,55$ & $\leq 0,50$ & $\leq 0,45$ \\
\hline Classe de concreto & Concreto armado & $\geq \mathrm{C} 20$ & $\geq \mathrm{C} 25$ & $\geq \mathrm{C} 30$ & $\geq \mathrm{C} 40$ \\
\cline { 2 - 6 } & Concreto protendido & $\geq \mathrm{C} 25$ & $\geq \mathrm{C} 30$ & $\geq \mathrm{C} 35$ & $\geq \mathrm{C} 40$ \\
\hline $\begin{array}{c}\text { Consumo de cimento } \\
\begin{array}{c}\text { Portland por metro } \\
\text { cúbico de concreto } \\
\left(\mathrm{kg} / \mathrm{m}^{3}\right)\end{array}\end{array}$ & $\begin{array}{c}\text { Concreto armado e } \\
\text { concreto protendido }\end{array}$ & $\geq 260$ & $\geq 280$ & $\geq 320$ & $\geq 360$ \\
\hline
\end{tabular}


Considerando um contexto geral no qual as construções em paredes de concreto se encontram em ambiente urbano, a classe de agressividade adequada é a classe II, moderada, com pequeno risco de deterioração da estrutura. Dessa forma, conforme Tabela 3.3, tem-se que a relação a/c adotada para os traços propostos deve respeitar o limite máximo de 0,60 e que o consumo de cimento deve ser de no mínimo $280 \mathrm{~kg} / \mathrm{m}^{3}$ de concreto.

Escolhida a relação a/c, determinam-se a dosagem do superplastificante por meio de ensaio realizado com o cone de Marsh e a quantidade de fíler com um ensaio conhecido como miniabatimento proposto por KANTRO (1980). Dessa forma, a dosagem do cimento se torna dependente da definição dos parâmetros apresentados. Por fim, os autores indicam que quando da utilização de pozolana, no caso a sílica ativa, sua quantidade pode variar de $5 \%$ a $15 \%$ da massa de cimento, sendo usualmente adotado o valor de 10\% (GOMES; BARROS, 2009).

Gomes (2002) indica, para a dosagem do superplastificante, a utilização do cone de Marsh com as dimensões apresentadas na Norma Europeia EN 445 (1996), de acordo com a Figura 3.2. No Brasil, o cone de Marsh é um equipamento normatizado pela NBR 7681-2:2013 - Calda de cimento para injeção - Parte 2: Determinação do índice de fluidez e da vida útil Método de ensaio (ABNT, 2013). Entretanto, essa norma define que a abertura inferior do funil deve ser $10 \mathrm{~mm}$ (Figura 3.3), valor diferente dos $8 \mathrm{~mm}$ adotados por Gomes (2002). O presente trabalho utilizou o funil definido pela NBR 7681-2:2013.

Figura 3.2 - Dimensões do cone de Marsh segundo EN 445 (1996).

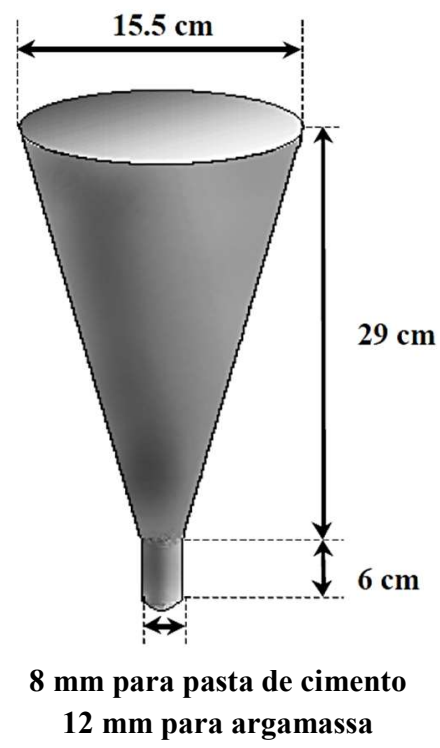

Fonte: Adaptado de Gomes (2002). 
Figura 3.3 - Cone de Marsh normatizado no Brasil, com dimensões internas apresentadas em milímetros.

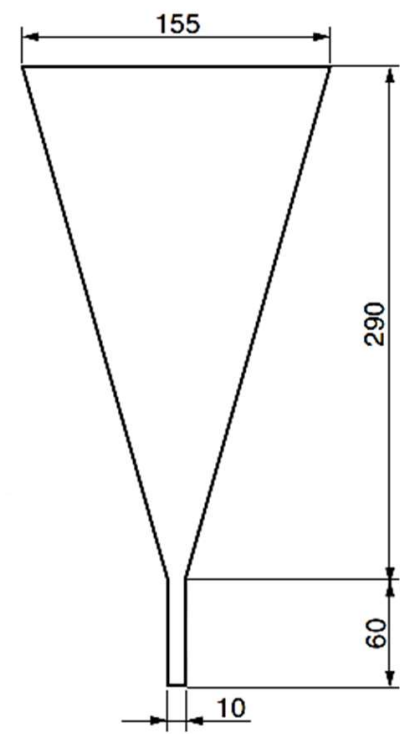

Fonte: NBR 7681-2:2013 (ABNT, 2013).

O procedimento para determinação da dosagem do superplastificante consiste em adicionar um litro da pasta de cimento no cone de Marsh e medir qual o tempo $(\mathrm{T})$ necessário para que $500 \mathrm{ml}$ da pasta fluam pela saída inferior do cone (Figura 3.4). O tempo (T) é um parâmetro inverso à fluidez da pasta e ao se variar a relação entre as massas de superplastificante e cimento $(\mathrm{sp} / \mathrm{c})$ é possível determinar uma curva de $\log (\mathrm{T})$ x $(\mathrm{sp} / \mathrm{c})$ (GOMES; BARROS, 2009).

Figura 3.4 - Ensaio com cone de Marsh em andamento.

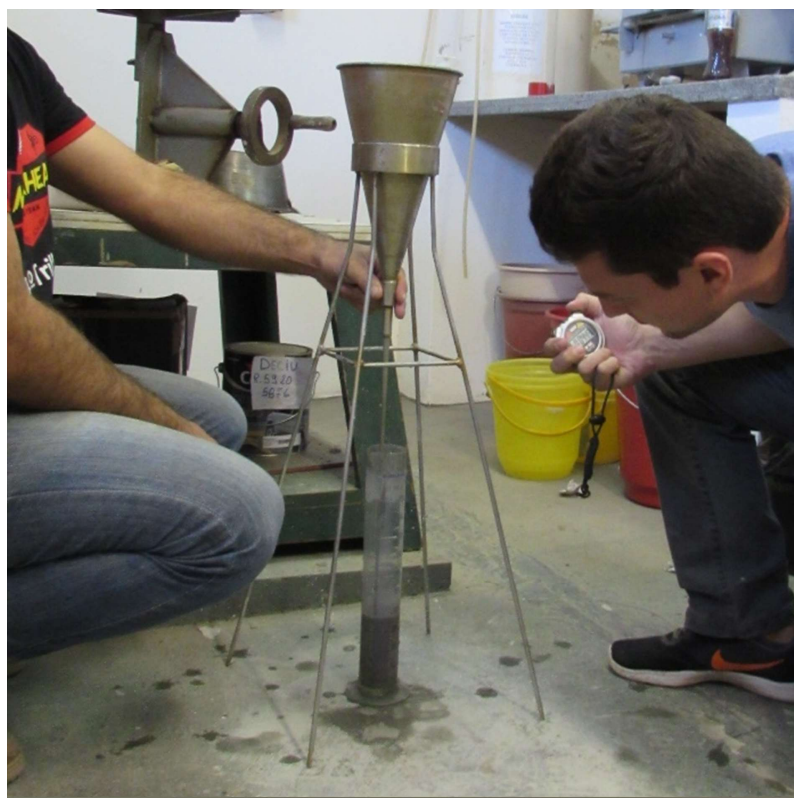

Fonte: Arquivo pessoal. 
A quantidade de superplastificante a ser adotada na dosagem é aquela representada pelo seu ponto de saturação. Gomes (2002) indica que esse ponto é representado na curva de $\log (\mathrm{T}) \times(\mathrm{sp} / \mathrm{c})$ como sendo aquele que apresenta um ângulo $\alpha$, formado com os dois pontos adjacentes na curva traçada, com valor entre $130^{\circ}$ e $150^{\circ}$, conforme ilustrado na Figura 3.5.

Figura 3.5 - Determinação do ponto de saturação do superplastificante.

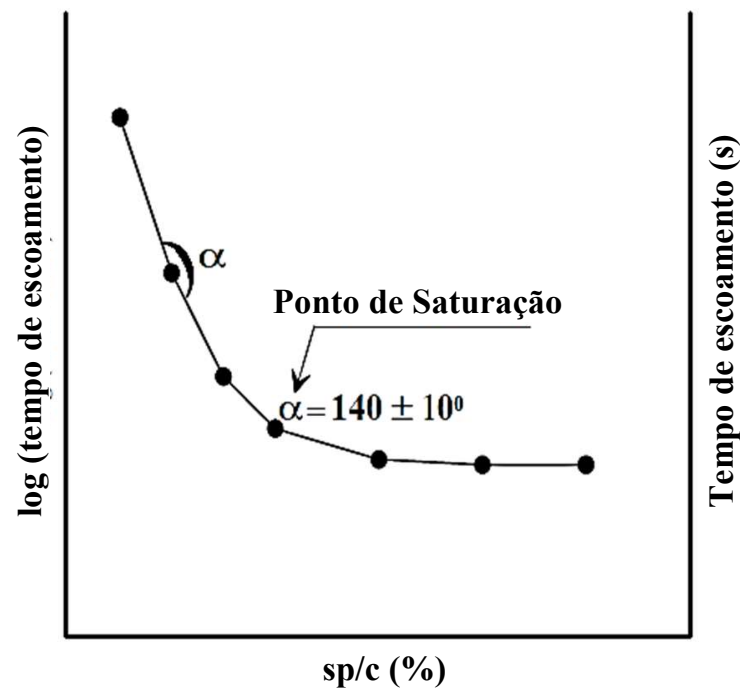

Fonte: Adaptado de Gomes (2002).

Neste trabalho, porém, foi considerado o método AFREM proposto por De Larrard et al. (1997), que considera a mesma curva do logaritmo do tempo de escoamento em função do teor de superplastificante. A diferença em relação ao proposto por Gomes (2002) é que a escolha do ponto de saturação é feita de acordo com a posição que uma reta com inclinação 2:5 tangencia a curva obtida (Figura 3.6).

Gomes e Barros (2009) destacam que o tempo de fluxo da pasta pelo cone de Marsh varia de acordo com a relação de f/c adotada, de forma que a dosagem do ponto de saturação do superplastificante se torna dependente dessa relação. Dessa forma, é importante determinar o ponto de saturação para diferentes relações de f/c.

O próximo passo para a dosagem é verificar o comportamento da pasta por meio do ensaio de miniabatimento a fim de que seja determinada a dosagem de fíler que atende aos requisitos necessários a uma pasta para CAA. O teste de miniabatimento, ou mini-slump, apresenta como vantagem o fato de ser rápido e permitir a análise de quantidade pequena de amostra, viabilizando a realização de diversos ensaios em algumas horas por uma única pessoa (KANTRO, 1980; GOMES; BARROS, 2009). A Figura 3.7 apresenta o minitronco de cone utilizado para realização do ensaio. 
Figura 3.6 - Ponto de saturação do superplastificante de acordo com o método AFREM, proposto por De Larrard et al. (1997).

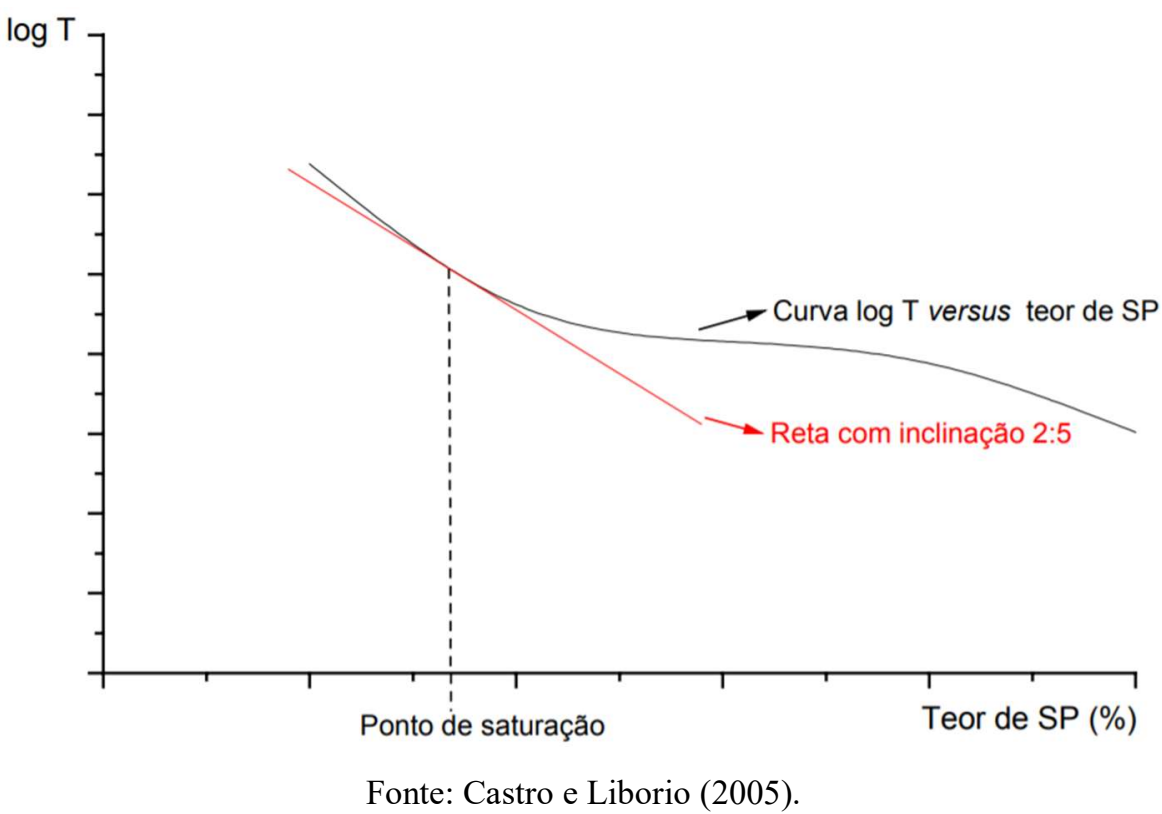

Figura 3.7 - Minitronco de cone para o ensaio de miniabatimento.

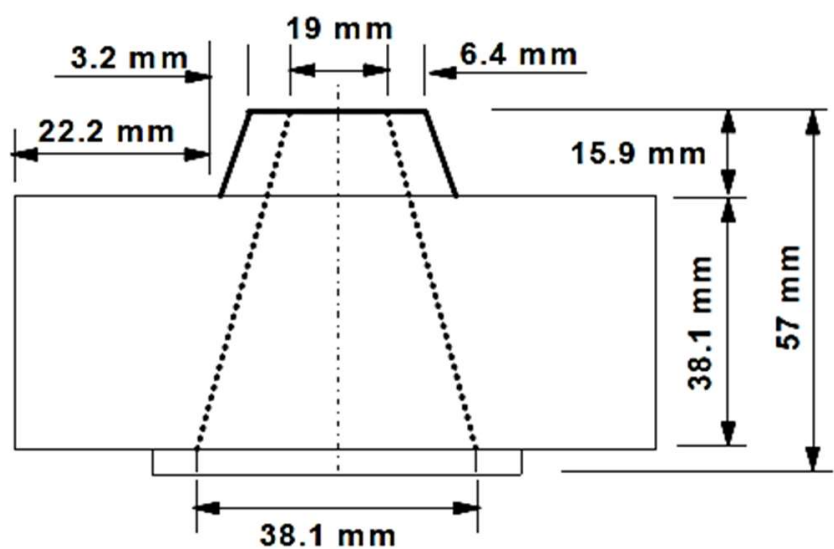

Fonte: Gomes (2002).

A preparação do ensaio começa com o posicionamento do cone sobre uma base plana e sem inclinação. Na sequência, o cone e a base sobre a qual aquele está apoiado devem ser umedecidos para que o cone seja preenchido com a amostra da pasta analisada. Uma espátula deve ser usada para o arrasamento da amostra de forma que fique nivelada com o topo do cone. Os flanges do cone servem para capturar o excesso de pasta retirado com a espátula. Em seguida, o cone deve ser levantado rapidamente em sentido vertical e o espalhamento da amostra deve ser medido (KANTRO, 1980; GOMES, 2002). 
Fixada a dosagem do ponto de saturação do superplastificante, obtida com o ensaio de Marsh, é possível realizar os ensaios de miniabatimento com diferentes relações f/c, sendo que esta será considerada adequada quando a pasta apresentar um diâmetro de extensão final de $(180 \pm 10) \mathrm{mm}$ e observado um tempo de $2 \mathrm{~s}$ a $4 \mathrm{~s}$ para ultrapassar um diâmetro de $115 \mathrm{~mm}$ (GOMES; GETTU; AGULLÓ, 2003). A Figura 3.8 mostra o esquema de ensaio.

Figura 3.8 - Esquema do ensaio de miniabatimento.

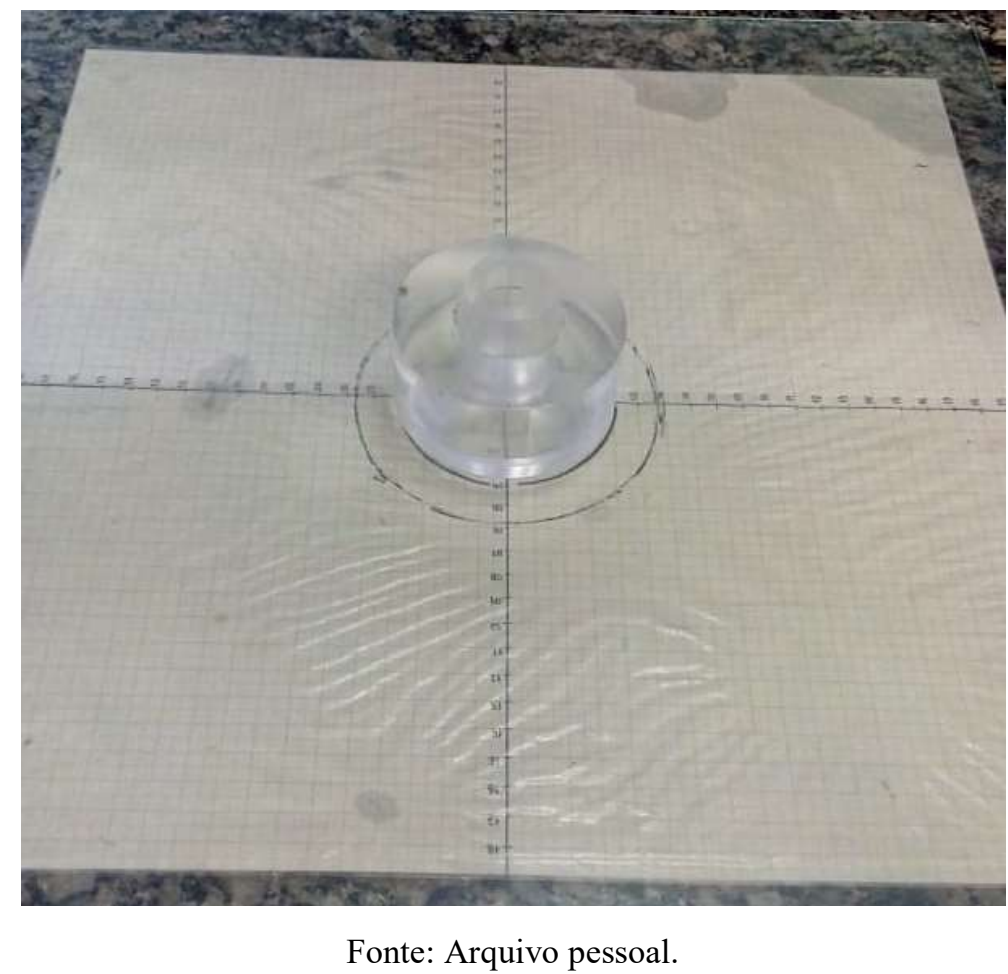

A análise conjunta dos resultados obtidos com o cone de Marsh e com o ensaio de miniabatimento permite determinar as relações de sp/c e f/c que atendem a um concreto com alta fluidez, sem segregação e com coesão moderada (GOMES; BARROS, 2009).

\subsubsection{Definição do esqueleto granular}

Em relação ao esqueleto granular, a combinação ótima de agregados é obtida ao se considerar a mistura de agregados graúdos e miúdos com maior massa específica e, consequentemente, o menor índice de vazios (GOMES; BARROS, 2009).

O procedimento de obtenção do esqueleto granular consiste simplesmente em colocar uma mistura de agregados graúdos e miúdos sem compactação em um recipiente de volume conhecido para serem pesados de maneira a se determinar sua massa unitária. Ao longo do ensaio, deve-se se variar a proporção entre os agregados, de forma que seja definida a massa 
unitária das diferentes combinações de agregados consideradas. Gomes e Barros (2009) recomendam que se faça no mínimo duas medidas da massa unitária para cada mistura e que seja considerada a média dos resultados. Além desses valores, deve ser determinado o teor de vazios referente a cada mistura por meio das Equações 3.5, 3.6 e 3.7.

$$
\begin{gathered}
\rho_{d m}=\frac{\rho_{s} \cdot s / a+\rho_{b} \cdot b / a}{100} \\
\omega_{u}=\frac{\omega_{t}}{V_{t}} \\
v=\frac{\rho_{d m}-\omega_{u}}{\rho_{d m}} \cdot 100
\end{gathered}
$$

Onde:

$\rho_{d m}$ é a densidade da mistura seca;

$\rho_{s}$ é a densidade seca da areia;

$s / a$ é a relação areia/agregados da mistura [\%];

$\rho_{b}$ é a densidade seca da brita;

$b / a$ é a relação brita/agregados da mistura;

$\omega_{u}$ é o peso total da mistura;

$V_{t}$ é o volume total da mistura;

$v$ é o percentual de vazios [\%].

Os resultados obtidos para cada mistura ensaiada são expressos em um gráfico de forma que se obtenha a mistura com maior massa unitária e menor teor de vazios e, assim, definindo o esqueleto granular. Um gráfico retirado de Gomes (2002) está apresentado na Figura 3.9 e exemplifica genericamente como os resultados devem ser representados. 
Figura 3.9 - Determinação do esqueleto granular da mistura.

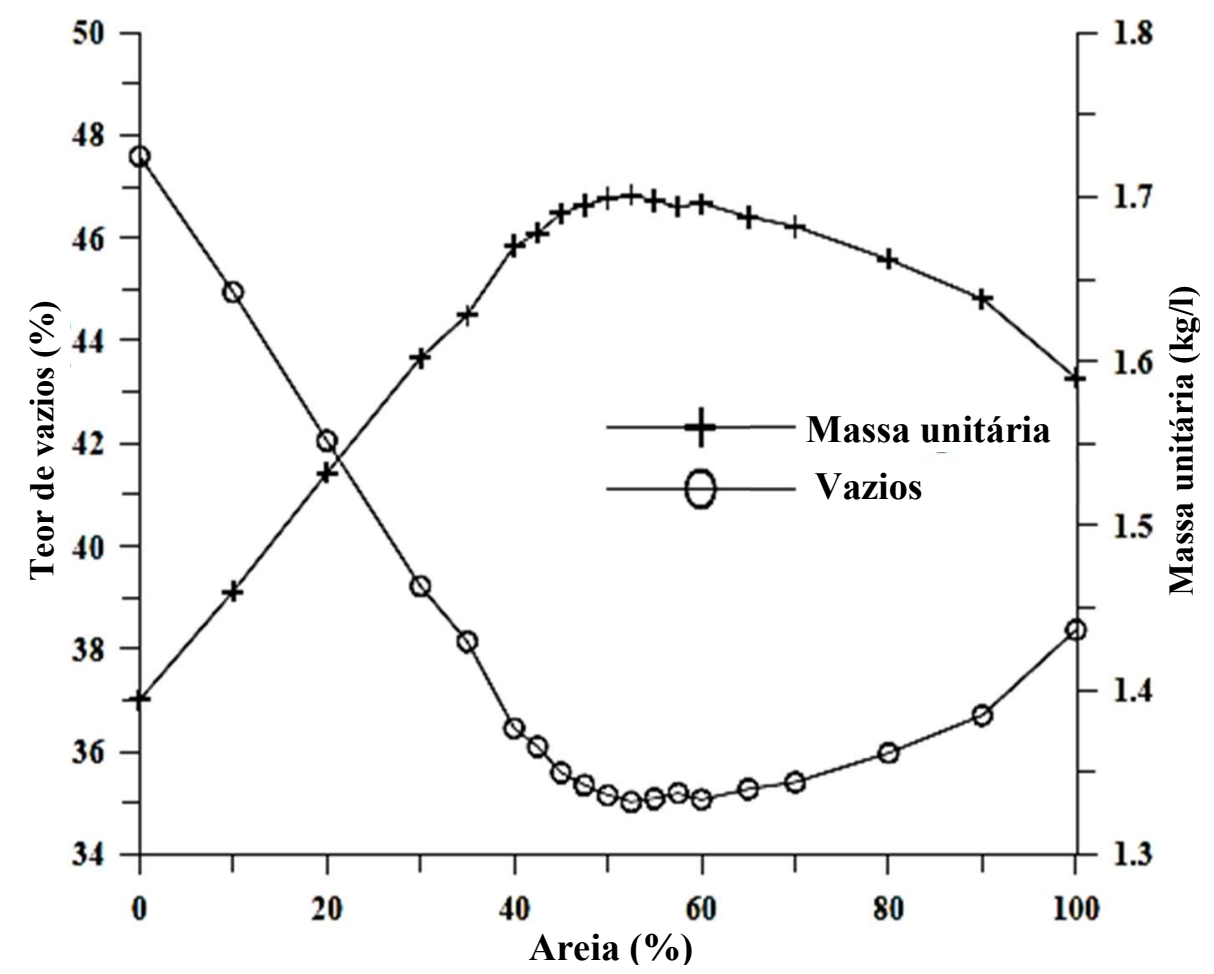

Fonte: Adaptado de Gomes (2002).

\subsubsection{Determinação da composição do CAA}

Inicialmente deve ser determinado o consumo de cimento, isto é, a massa de cimento para um metro cúbico de concreto com base nos parâmetros definidos anteriormente. Gomes e Barros (2009) apresentam a seguinte equação para encontrar o consumo de cimento (C), que nada mais é do que uma representação da Equação 3.4 com a massa (C) em evidência.

$$
C=\frac{V_{p}}{\frac{1}{\rho_{c}}+\frac{a / c}{\rho_{a}}+\frac{f / c}{\rho_{f}}+\frac{s f / c}{\rho_{s f}}+\frac{(s p / c) \cdot\left(100 / T_{s p}\right)}{\rho_{s p}}-\frac{(s p / c) \cdot\left[\left(100 / T_{s p}\right)-1\right]}{\rho_{a}}}
$$

Definidos todos os parâmetros, resta apenas encontrar o conteúdo de agregados por volume de pasta. Isso foi feito variando-se o volume de pasta no concreto de forma a obter uma composição de concreto que atendesse as propriedades de autoadensabilidade pré-estabelecidas necessárias para sua classificação como CAA (GOMES; BARROS, 2009). Em estudo apresentado por Gomes (2002), o volume de pasta adequado para produção de concreto autoadensável com uso de fíler foi de $38 \%$ e, no caso do uso conjunto de sílica e fíler, poderia 
ser utilizado um volume de pasta de $38 \%$ ou $40 \%$. Dessa forma, a composição do concreto só é definida após a realização dos ensaios de caracterização do concreto no estado fresco.

\subsubsection{Procedimento de mistura}

Neste trabalho, os traços estudados foram misturados em betoneiras de eixo vertical com capacidade adequada ao volume considerado. O procedimento consistiu em:

- Molhar a betoneira e deixar a água escorrer antes da adição dos materiais;

- Adicionar os agregados graúdos e miúdos em sua totalidade com cerca de $50 \%$ da água total e misturar durante 1 minuto;

- Adicionar os materiais finos e o restante da água, e misturar por mais 5 minutos;

- Adicionar o aditivo superplastificante e misturar por mais 5 minutos.

Para os traços que utilizavam aditivo incorporador de ar, foi seguido o mesmo procedimento de mistura dos traços de referência, sendo o incorporador adicionado após o fim da mistura com o aditivo superplastificante, conforme orientação do fabricante e indicação de Attachaiyawuth et al. (2016). O passo seguinte ao procedimento anterior foi:

- Adicionar o aditivo incorporador de ar e fazer medições da massa específica e, consequentemente, do teor de ar ao longo do tempo de mistura para definir o momento de parada. Isso foi feito pois a incorporação de ar se mostrou muito difícil de controlar, sendo necessário um critério de parada mais rigoroso do que simplesmente um tempo pré-estabelecido.

Definido o procedimento de mistura, os concretos foram produzidos e caracterizados conforme Figura 3.10. Posteriormente, os traços foram modificados com aditivo incorporador de ar e avaliados de acordo com Figura 3.11. 
Figura 3.10 - Caracterização cos concretos autoadensáveis.

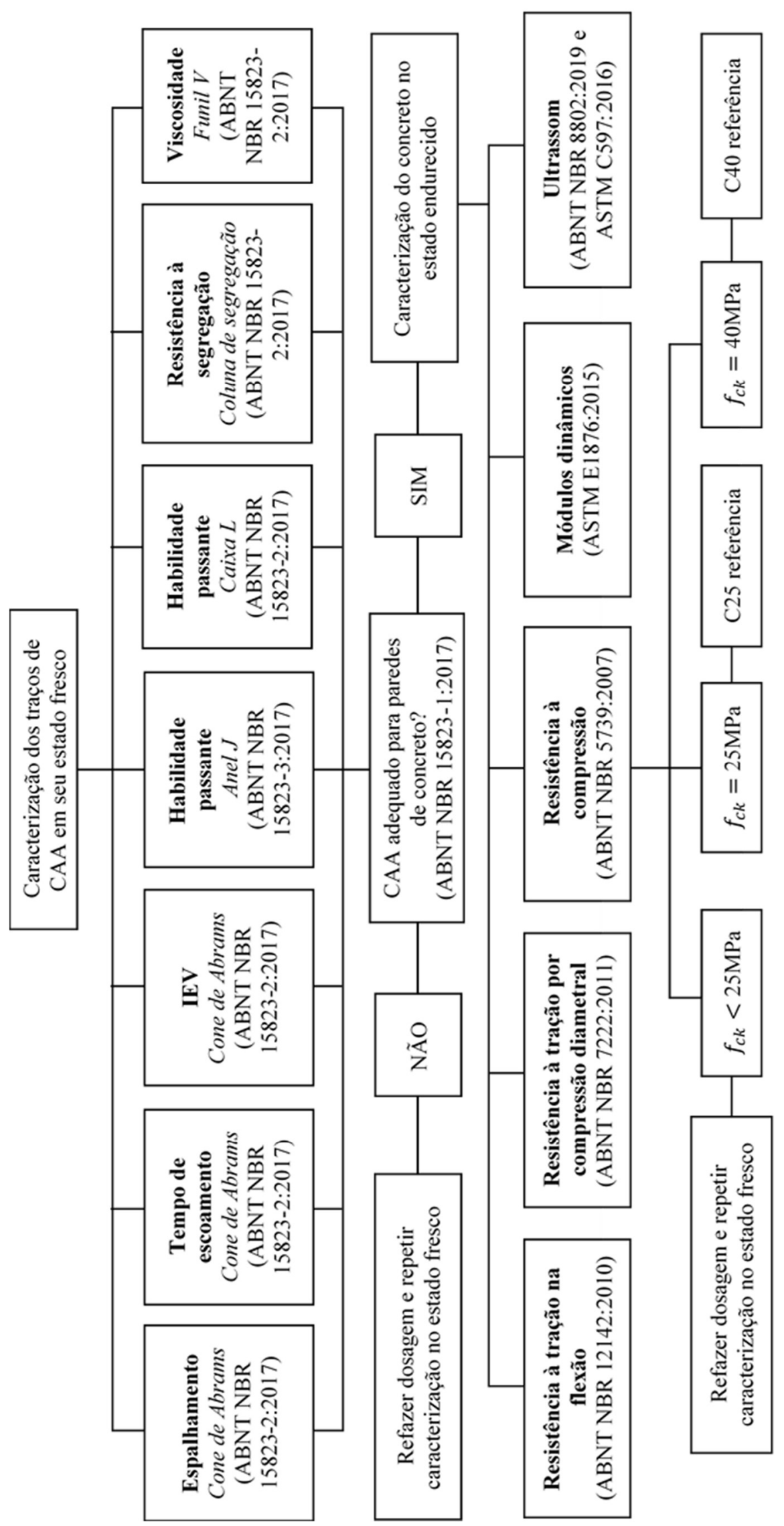

Fonte: Elaborada pelo autor. 
Figura 3.11 - Modificação dos traços de referência para análises posteriores.

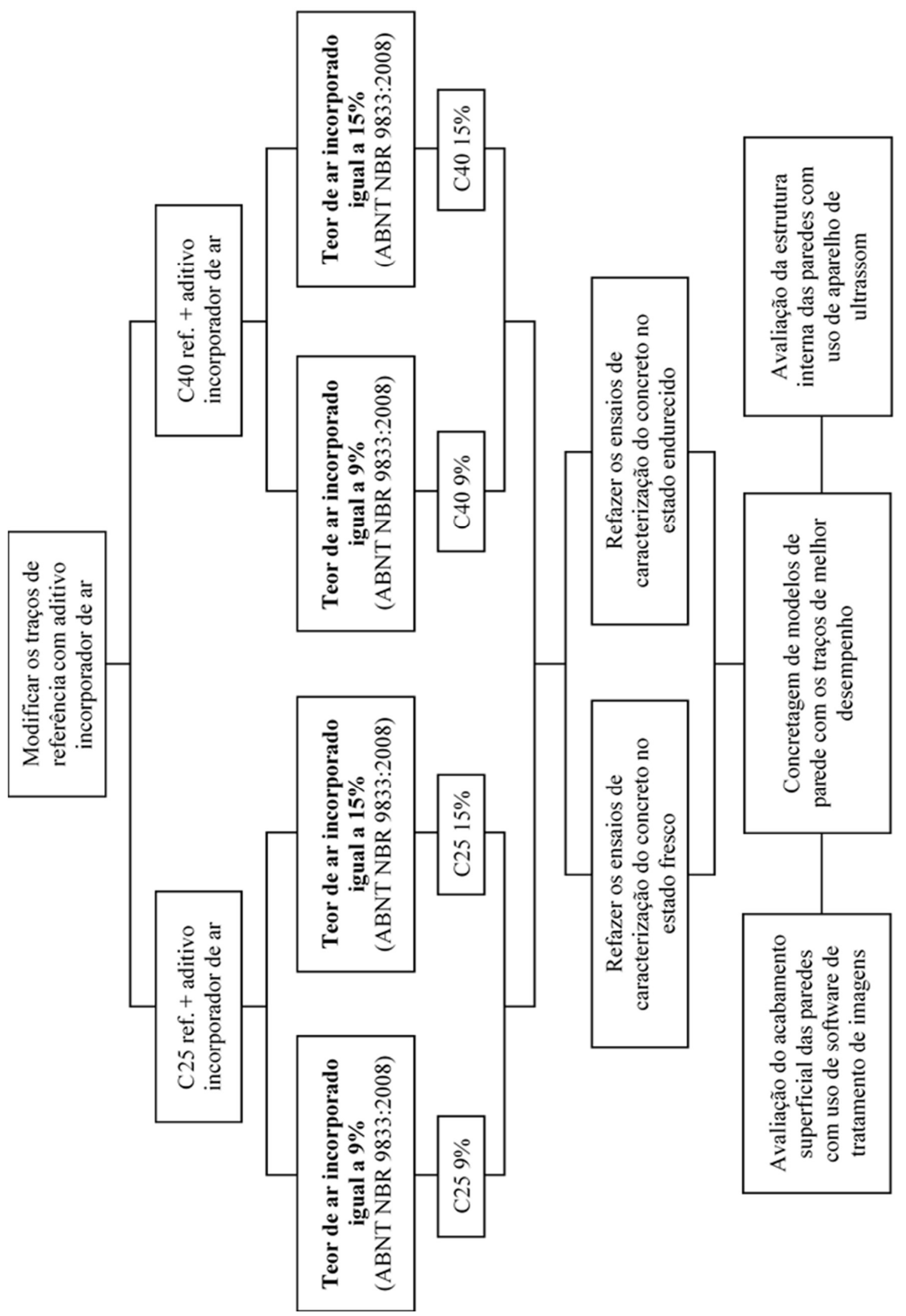

Fonte: Elaborada pelo autor. 


\subsection{Medição das propriedades do concreto fresco}

\subsubsection{Propriedades de autoadensabilidade do concreto}

Devem ser determinadas as diferentes propriedades de autoadensabilidade no estado fresco que permitem fazer a classificação do concreto como sendo um CAA, a fim de que sejam alcançadas as características de interesse para o material a ser utilizado na execução de paredes de concreto moldadas no local. Essas propriedades e seus respectivos métodos de ensaio estão apresentados nas seis diferentes partes da NBR 15823:2017 e mostrados na sequência.

- Determinação do espalhamento (slump-flow) — Método do cone de Abrams.

No Brasil, este ensaio é regulamentado pela NBR 15823-2:2017 - Concreto autoadensável - Parte 2: Determinação do espalhamento, do tempo de escoamento e do índice de estabilidade visual - Método do cone de Abrams (ABNT, 2017b). No ensaio, um molde tronco-cônico (cone de Abrams) é posicionado sobre uma placa-base metálica e em seguida preenchido com concreto. O molde é então retirado e o concreto se espalha de maneira praticamente uniforme pela placa-base, permitindo avaliar a fluidez do mesmo. O slump-flow fica definido pela média aritmética em milímetros $(\mathrm{mm})$ de duas medidas do diâmetro referente ao material espalhado sobre a placa metálica. A Figura 3.12 representa esquematicamente o ensaio em questão, enquanto que a Figura 3.13 exemplifica a medição.

Figura 3.12 - Método do Cone de Abrams.

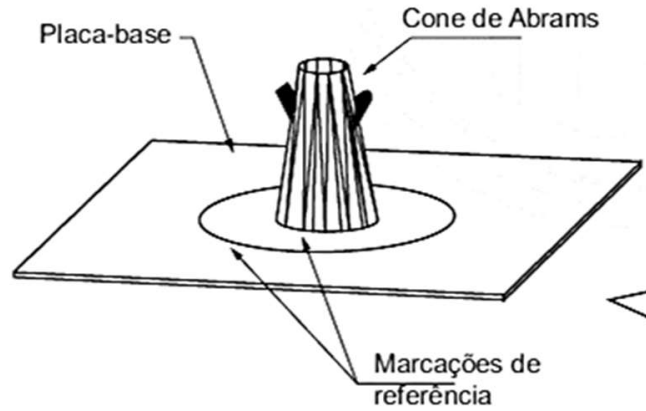

a) Perspectiva

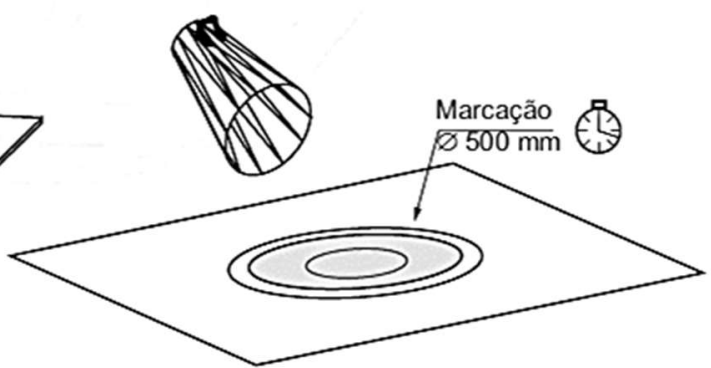

b) Execução do ensaio

Fonte: NBR 15823-2:2017 (ABNT, 2017b). 
Figura 3.13 - Determinação do espalhamento.

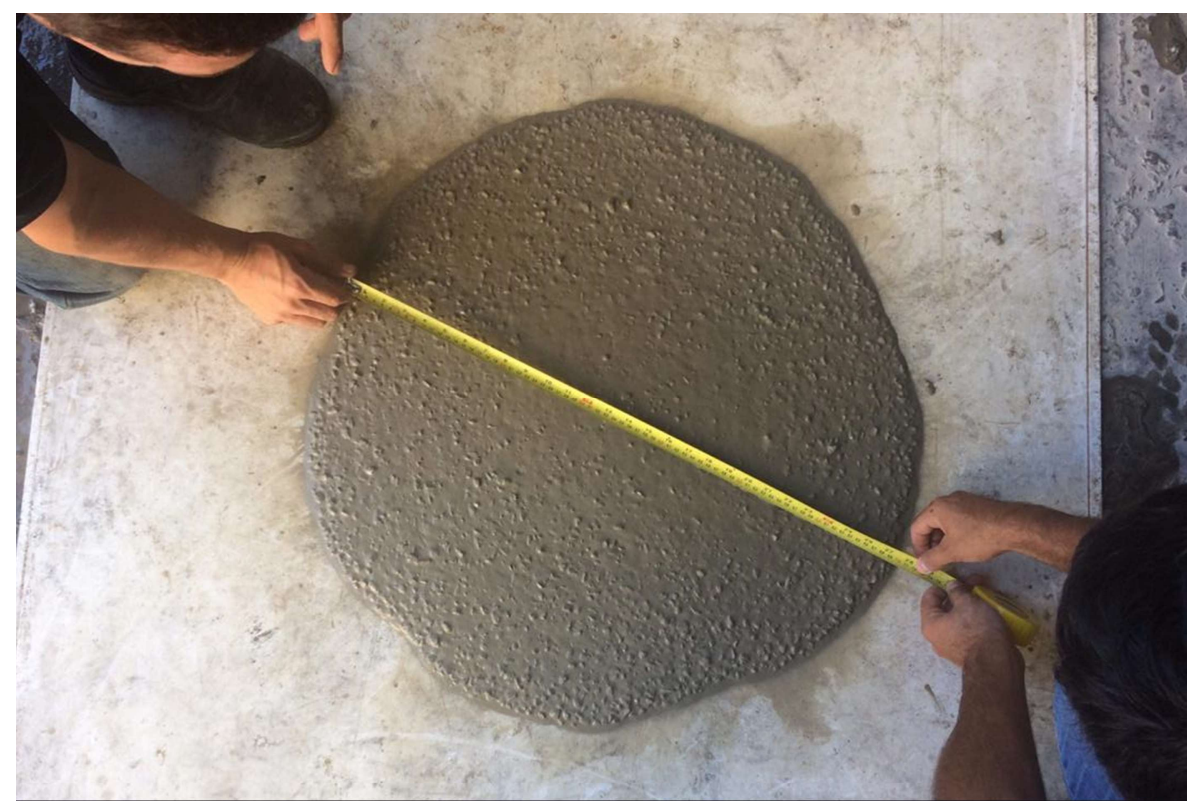

Fonte: Arquivo pessoal.

Com base nos valores obtidos, a NBR 15823-1:2017 (ABNT, 2017a) define a classe de espalhamento do CAA analisado de acordo com a Tabela 3.4.

Tabela 3.4 - Classes de espalhamento (slump-flow).

\begin{tabular}{cc}
\hline Classe & Espalhamento (mm) \\
\hline$S F 1$ & 550 a 650 \\
$S F 2$ & 660 a 750 \\
$S F 3$ & 760 a 850 \\
\hline Fonte: NBR 15823-1:2017 (ABNT, 2017a).
\end{tabular}

A NBR 15823-1:2017, em seu Anexo A, recomenda que para "estruturas com alta densidade de armadura e/ou de forma arquitetônica complexa, com o uso de concreto com agregado graúdo de pequenas dimensões" deve ser utilizado CAA que se enquadre na classe de espalhamento $S F 3$ (ABNT, 2017a). Considera-se que as paredes de concreto fazem parte dessa definição. Portanto, o presente trabalho deve propor traços de CAA que respeitem a faixa de espalhamento de 760 a $850 \mathrm{~mm}$.

Apesar da escolha da classe SF 3 a partir de interpretação normativa, pode ser observado em Costa e Lima (2018) que em uma obra executada na cidade de São Paulo, dentre as características do CAA usado no sistema de paredes de concreto, está especificado um espalhamento de $(700 \pm 50) \mathrm{mm}$ e indicada classe de espalhamento SF 2. Em um outro 
exemplo, Monge e Wendler (2018) apresentam um modelo de especificação do concreto para paredes indicando espalhamento de $(600 \pm 50) \mathrm{mm}$, referente à classe SF 1. Dessa maneira, entende-se que é possível a utilização de CAAs pertencentes a quaisquer das 3 classes de espalhamento, quando do seu uso em paredes de concreto moldadas no local.

- Determinação do tempo de escoamento - Método do cone de Abrams.

O ensaio que define o tempo de escoamento é o mesmo apresentado para o slumpflow, com utilização do cone de Abrams e placa-base metálica. "O resultado do ensaio $\left(t_{500}\right)$ é o intervalo de tempo, em segundos, entre o início e o final do escoamento do concreto, a partir do diâmetro do molde $(200 \mathrm{~mm})$ até a marca circular de diâmetro $500 \mathrm{~mm}$ da placa-base" (ABNT, 2017b).

A classe de viscosidade plástica aparente do CAA é determinada a partir dos valores de $t_{500}$, de acordo com a Tabela 3.5 retirada da NBR 15823-1:2017 (ABNT, 2017a).

Tabela 3.5 - Classes de viscosidade plástica aparente $t_{500}$ (sob fluxo livre).

\begin{tabular}{cc}
\hline Classe & $\boldsymbol{t}_{\mathbf{5 0 0}}(\mathbf{s})$ \\
\hline$V S 1$ & $\leq 2$ \\
$V S 2$ & $>2$ \\
\hline Fonte: NBR 15823-1:2017 (ABNT, 2017a).
\end{tabular}

O Anexo A da NBR 15823-1:2017 indica que "para elementos estruturais com alta densidade de armadura e embutidos" deve ser utilizado concreto de classe VS 1 (ABNT, 2017a). Assim, o CAA proposto nesse trabalho para uso em paredes de concreto deve apresentar tempo de escoamento $t_{500}$ de, no máximo, dois segundos.

- Determinação do índice de estabilidade visual — Método do cone de Abrams.

Esse parâmetro também é definido por meio do espalhamento do concreto pelo cone de Abrams. O resultado do ensaio de índice de estabilidade visual (IEV) deve ser determinado visualmente a partir de análise do concreto logo após o fim do espalhamento (ABNT, 2017b). A Tabela 3.6 apresenta os valores de IEV junto aos critérios que permitem fazer a avaliação qualitativa do CAA, com esquematização proposta na Figura 3.14 e exemplo de situação real na Figura 3.15 
Tabela 3.6 - Classes de índice de estabilidade visual (IEV).

\begin{tabular}{cc}
\hline Classe & IEV \\
\hline$I E V 0$ (Altamente estável) & Sem evidência de segregação ou exsudação \\
$I E V$ 1 (Estável) & Sem evidência de segregação e leve exsudação \\
$I E V$ 2 (Instável) & $\begin{array}{c}\text { Presença de pequena auréola de argamassa }(\leq 10 \mathrm{~mm}) \text { e/ou } \\
\text { empilhamento de agregados no centro do concreto }\end{array}$ \\
IEV 3 (Altamente instável) & $\begin{array}{c}\text { Segregação claramente evidenciada pela concentração de } \\
\text { agregados no centro do concreto ou pela dispersão de } \\
\text { argamassa nas extremidades (auréola de argamassa }>10 \mathrm{~mm})\end{array}$ \\
\hline & Fonte: NBR 15823-2:2017 (ABNT, 2017b).
\end{tabular}

Figura 3.14 - Classes do índice de estabilidade visual (IEV).

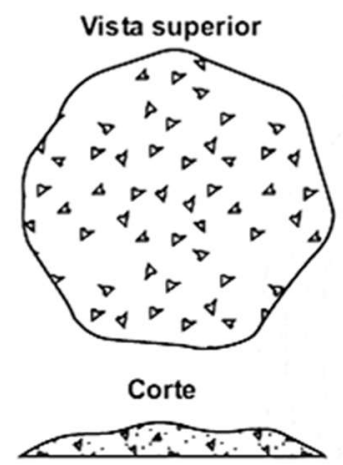

a) IEV 0

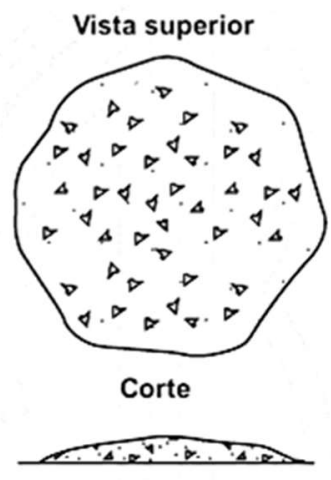

b) IEV 1

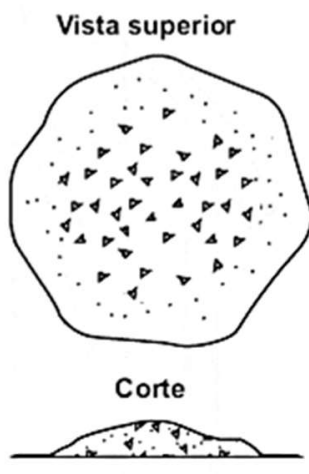

c) IEV 2

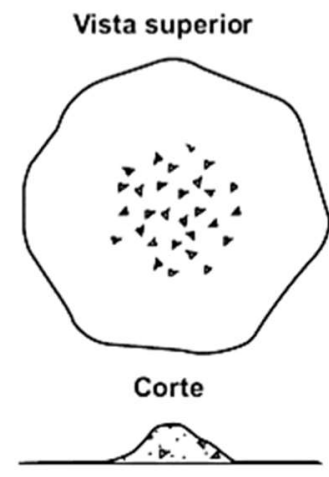

d) IEV 3

Fonte: NBR 15823-2:2017 (ABNT, 2017b).

Figura 3.15 - Análise do índice de estabilidade visual (IEV).
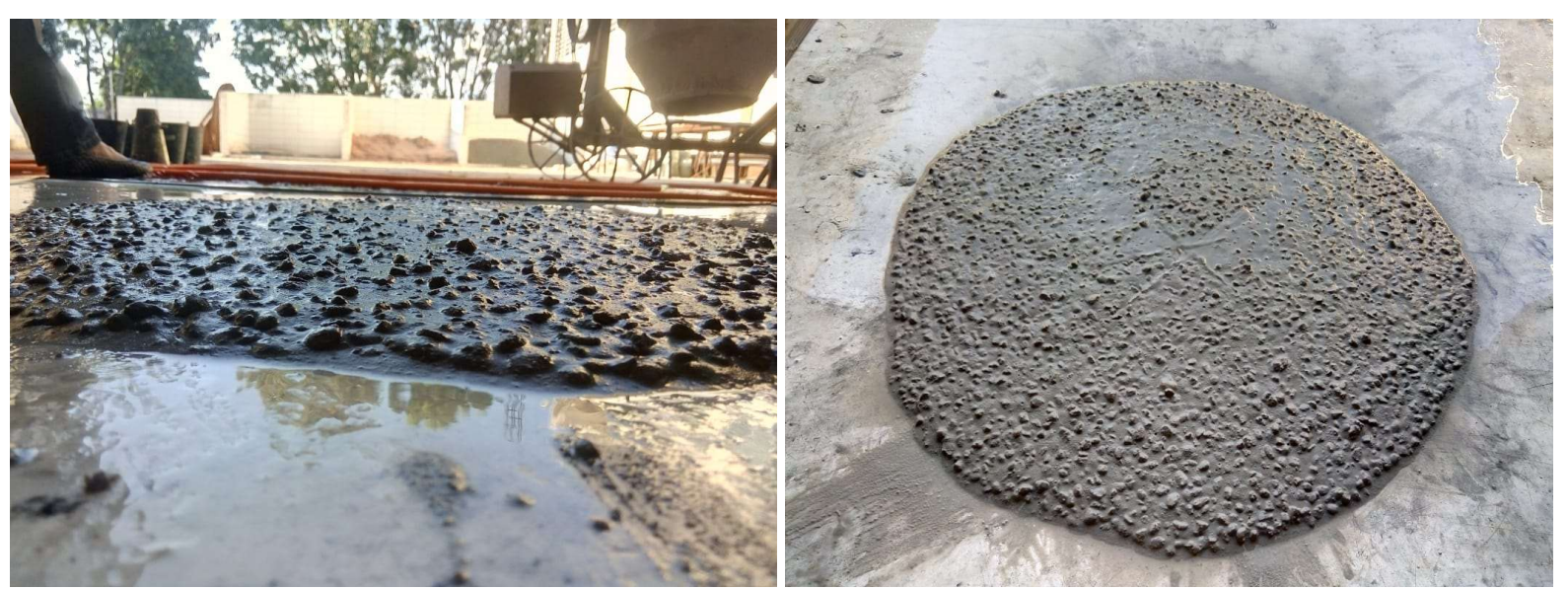

Fonte: Arquivo pessoal. 
- Determinação da habilidade passante - Método do anel J.

O ensaio que define esse parâmetro consiste em uma adaptação do Método do cone de Abrams, onde um anel metálico, constituído verticalmente por barras de aço, é posicionado sobre a placa-base e ao redor do molde (Figuras 3.16 e 3.17). De acordo com a NBR 15823-3Concreto autoadensável - Parte 3: Determinação da habilidade passante - Método do anel J, o cone deve ser posicionado com sua abertura menor para baixo, ao contrário do que acontece na determinação dos três parâmetros anteriores (ABNT, 2017c).

Figura 3.16 - Anel $J$.
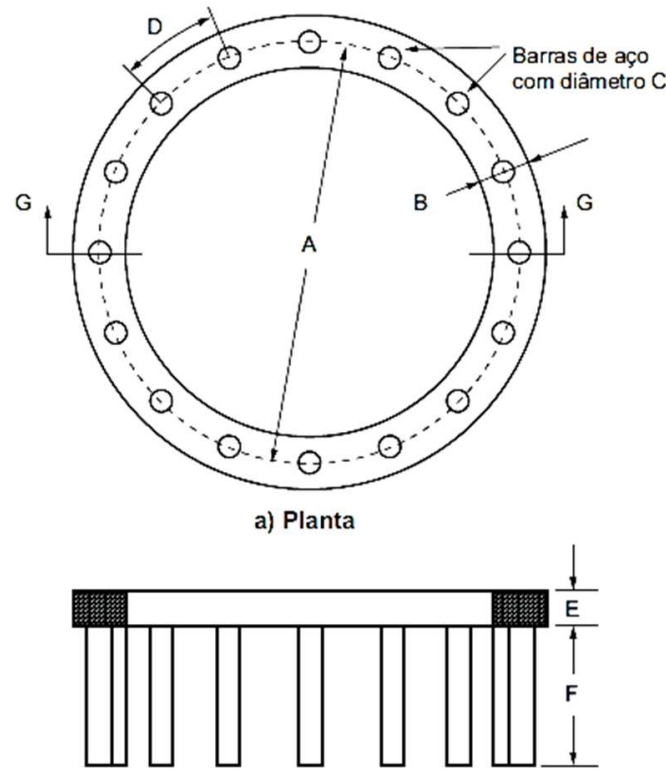

a) Planta

b) Corte G-G

\begin{tabular}{|c|c|}
\hline \multicolumn{2}{|c|}{$\begin{array}{c}\text { Dimensões } \\
\mathrm{mm}\end{array}$} \\
\hline $\mathrm{A}$ & $300 \pm 3,3$ \\
\hline $\mathrm{B}$ & $38 \pm 1,5$ \\
\hline $\mathrm{C}$ & $16 \pm 3,3$ \\
\hline $\mathrm{D}$ & $59 \pm 1,5$ \\
\hline $\mathrm{E}$ & $25 \pm 1,5$ \\
\hline F & $120 \pm 1,5$ \\
\hline
\end{tabular}

Fonte: NBR 15823-3:2017 (ABNT, 2017c).

Figura 3.17 - Exemplo do ensaio de Anel $J$ em andamento.

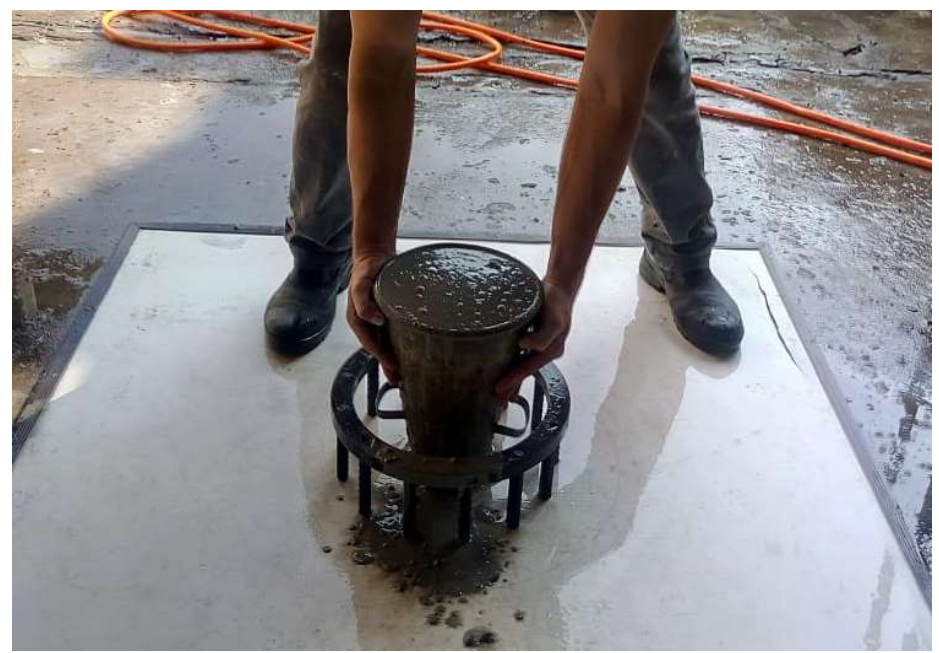

Fonte: Arquivo pessoal. 
Assim como o nome permite presumir, este ensaio mede a habilidade passante do concreto, ou seja, a capacidade deste de fluir livremente por entre as barras de aço sob efeito apenas de seu peso próprio.

A classe de habilidade passante é determinada a partir da diferença entre o diâmetro médio de espalhamento obtido com e sem a utilização do anel $J$, expressa em milímetros $(\mathrm{mm})$, conforme apresentado na Tabela 3.7.

Tabela 3.7 - Classes de habilidade passante pelo anel $J$ (sob fluxo livre).

\begin{tabular}{cc}
\hline Classe & Anel $\boldsymbol{J}(\mathbf{m m})$ \\
\hline$P J 1$ & 0 a 25 com 16 barras de aço \\
$P J 2$ & 25 a 50 com 16 barras de aço \\
\hline Fonte: NBR $15823-1: 2017$ (ABNT, 2017a).
\end{tabular}

A NBR 15823-1:2017 (ABNT, 2017a), em seu Anexo A, indica que "para a maioria das aplicações correntes e/ou elementos estruturais com espaçamentos de armadura de $60 \mathrm{~mm}$ a $80 \mathrm{~mm}$ ", casos nos quais se enquadram as paredes de concreto, deve ser utilizado CAA de classe $P J 1$.

- Determinação da habilidade passante - Método da caixa $L$.

Assim como apresentado no ensaio anterior, o Método da caixa L é uma medida da habilidade passante do CAA, com a diferença de ser uma análise sob fluxo confinado. Para esse ensaio, é utilizado dispositivo conhecido como caixa $L$ (Figuras 3.18 a 3.20), de acordo com as especificações da NBR 15823-4:2017 - Concreto autoadensável - Parte 4: Determinação da habilidade passante - Métodos da caixa L e da caixa U (ABNT, 2017d).

O ensaio consiste em encher a câmara vertical com concreto mantendo a comporta fechada. Após $(60 \pm 10)$ segundos do preenchimento da câmara, a comporta deve ser aberta de maneira rápida e uniforme para permitir o escoamento do concreto sobre a câmara horizontal (ABNT, 2017d). A habilidade passante (HP) é representada pela razão entre as alturas da superfície do concreto nas extremidades da câmara horizontal $\left(H_{2} / H_{1}\right)$, assim como representado na Figura 3.19. 
Figura 3.18 - Caixa $L$ - Perspectiva.

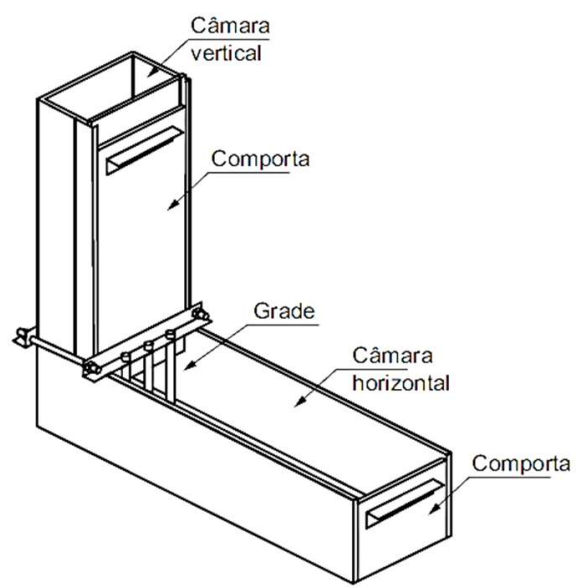

Fonte: NBR 15823-4:2017 (ABNT, 2017d).

Figura 3.19 - Indicação das alturas $H_{1}$ e $H_{2}$.

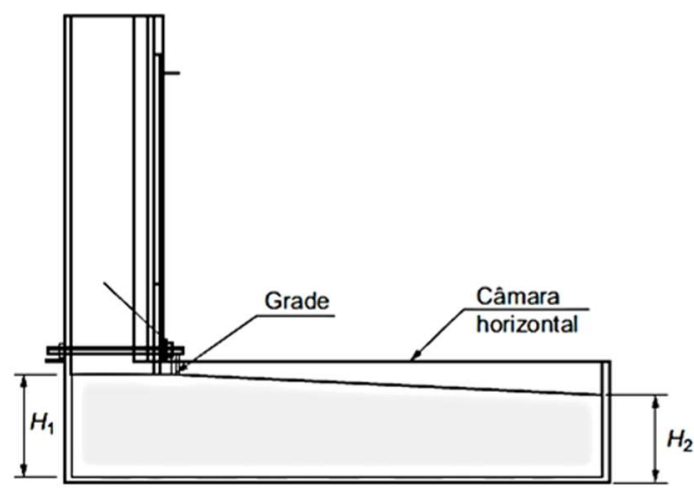

Fonte: NBR 15823-4:2017 (ABNT, 2017d).

Figura 3.20 - Exemplo do ensaio de Caixa $L$ em andamento antes da abertura da comporta.

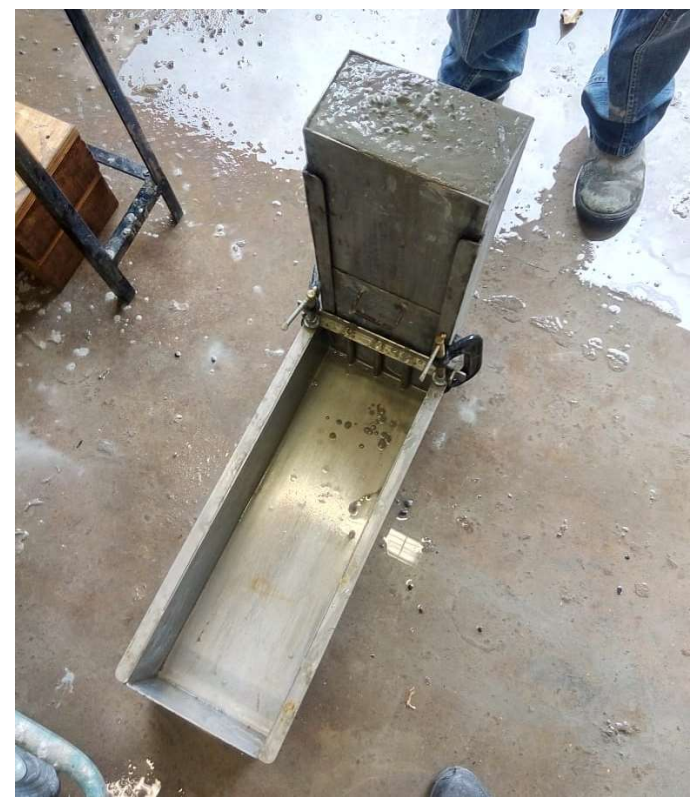

Fonte: Arquivo pessoal. 
A classe de habilidade passante, definida pela NBR15823-1:2017, é dependente da razão entre $H_{2}$ e $H_{1}$ e ainda da quantidade de barras presentes na grade utilizada (ABNT, 2017a). A Tabela 3.8 determina a classes de habilidade passante pela caixa L.

Tabela 3.8 - Classes de habilidade passante pela caixa $L$ (sob fluxo confinado).

\begin{tabular}{lc}
\hline Classe & Caixa $\boldsymbol{L}\left(\boldsymbol{H}_{\mathbf{2}} / \boldsymbol{H}_{\mathbf{1}}\right)$ \\
\hline$P L 1$ & $\geq 0,80$, com duas barras de aço \\
$P L 2$ & $\geq 0,80$, com três barras de aço \\
\hline Fonte: NBR & $15823-1: 2017$ (ABNT, 2017a).
\end{tabular}

O Anexo A da NBR 15823-1:2017 propõe que para situações de uso, assim como as apresentadas no caso do anel $J$, ou seja, "para a maioria das aplicações correntes e/ou elementos estruturais com espaçamentos de armadura de $60 \mathrm{~mm}$ a $80 \mathrm{~mm}$ " deve ser utilizado concreto de classe $P L 2$ (ABNT, 2017a). Isso significa que para o presente trabalho devem ser propostos traços que se adequem a essa classe.

- Determinação da viscosidade - Método do funil $V$.

Este ensaio é regulamentado pela NBR 15823-5:2017 - Concreto autoadensável Parte 5: Determinação da viscosidade - Método do funil V(ABNT, 2017e). Ele é utilizado na determinação da viscosidade do CAA, o que é feito a partir da medida do tempo de escoamento do concreto através de um dispositivo conhecido como funil $V$, apresentado nas Figura $3.21 \mathrm{e}$ 3.22 .

Figura 3.21 - Funil $V$. Dimensões em centímetros.

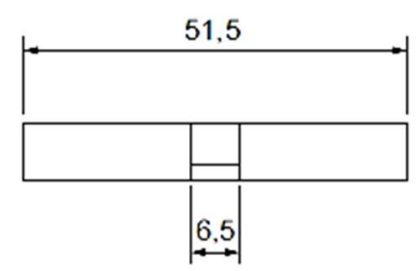

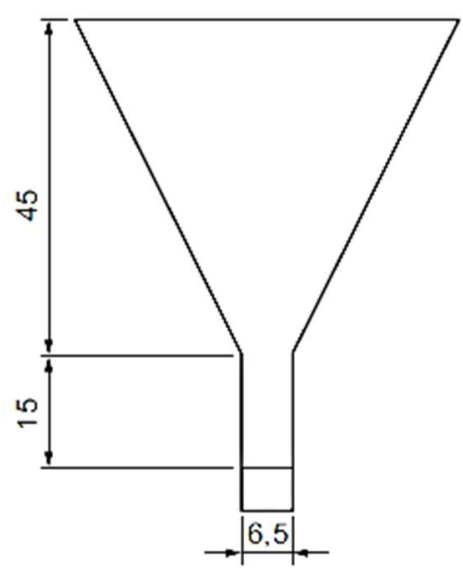

b) Vista frontal

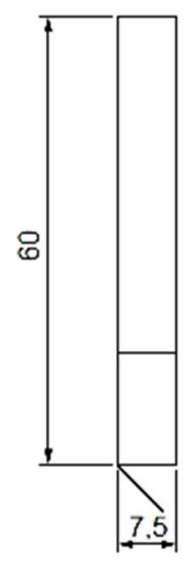

c) Vista lateral

a) Vista em planta

Fonte: NBR 15823-5:2017 (ABNT, 2017e). 
O ensaio consiste em preencher completamente o funil $V$ com concreto, mantendo fechada a comporta existente na parte inferior. A comporta deve ser aberta $(10 \pm 2)$ segundos após o funil ser preenchido com o material. Um cronômetro deve ser acionado juntamente com a abertura da comporta para medir o tempo necessário para o escoamento completo do concreto pelo funil, tempo esse denominado de $T_{10_{\text {seg }}}$ (ABNT, 2017e).

Figura 3.22 - Preparação do ensaio com funil $V$.

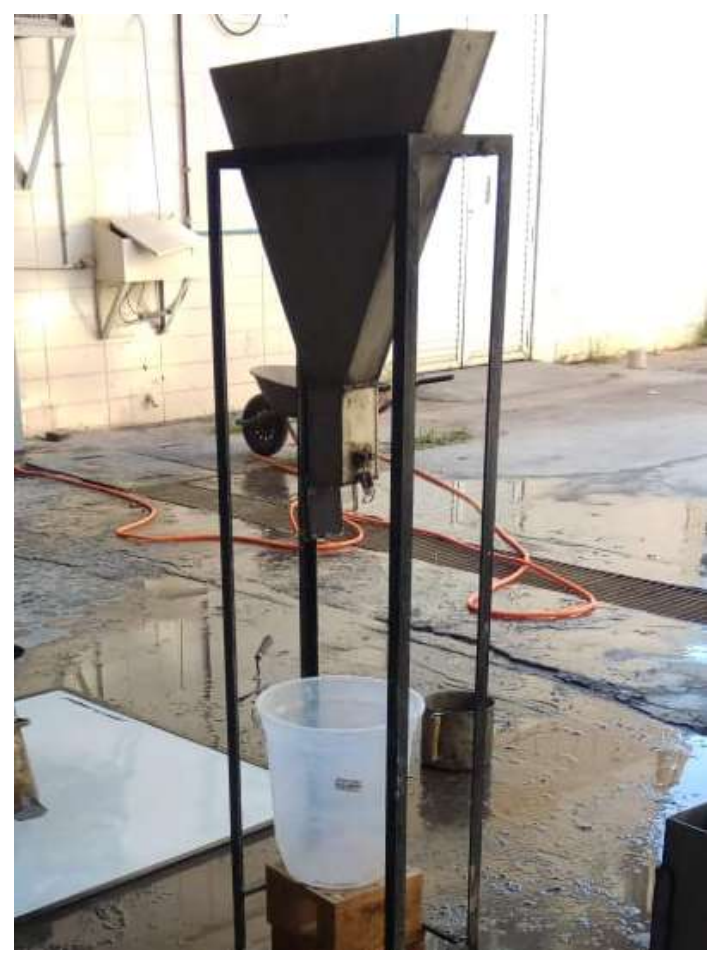

Fonte: Arquivo pessoal.

Para o ensaio ser considerado válido, o fluxo de concreto deve ser contínuo, sendo que no caso de algum tipo de obstrução o ensaio deve ser repetido. Caso alguma obstrução venha a acontecer também no segundo ensaio, o concreto não apresenta a viscosidade e a habilidade passante necessárias para ser considerado autoadensável (ABNT, 2017e).

A NBR 15823-1:2017 define a classe de viscosidade plástica aparente do concreto em função do tempo necessário para o escoamento total pelo funil $V$ de acordo com a Tabela 3.9.

Tabela 3.9 - Classes de viscosidade plástica aparente pelo funil $V$ (sob fluxo confinado).

\begin{tabular}{cc}
\hline Classe & Funil $\boldsymbol{V}(\mathbf{s})$ \\
\hline$V F 1$ & $<9$ \\
$V F 2$ & 9 a 25 \\
\hline onte: NBR 15823-1:2017 (ABNT, 2017a)
\end{tabular}


Assim como no caso do tempo de escoamento $t_{500}$, o Anexo A da NBR 158231:2017 indica que em aplicações "para elementos estruturais com alta densidade de armadura e embutidos" deve ser utilizado concreto de classe VF 1 (ABNT, 2017a). Dessa forma, os traços propostos neste trabalho devem respeitar um tempo $T_{10_{\text {seg }}}$ menor que nove segundos.

- Determinação da resistência à segregação — Método da coluna de segregação.

O último ensaio obrigatório para classificação de um concreto como CAA é o da determinação da resistência à segregação por meio do método da coluna de segregação, seguindo as especificações da NBR 15823-6:2017 - Concreto autoadensável - Parte 6: Determinação da resistência à segregação - Métodos da coluna de segregação e da peneira (ABNT, 2017f). A coluna de segregação está representada nas Figuras 3.23 e 3.24.

Neste ensaio, o concreto deve ser colocado dentro da coluna de segregação até o topo de maneira uniforme e sem interrupção. Cerca de 20 minutos após a moldagem, as porções de concreto referentes às camadas de topo e de base devem ser retiradas da coluna com auxílio de chapa metálica para que sejam lavadas individualmente sobre peneira com abertura de malha $4,75 \mathrm{~mm}$. Esse procedimento é realizado com o intuito de se retirar completamente a argamassa, limpando os agregados graúdos. Na sequência, os agregados devem ser submetidos a secagem superficial para posterior pesagem (ABNT, 2017f).

A resistência à segregação é determinada em função das massas obtidas para os agregados graúdos do topo e da base da coluna. $\mathrm{O}$ valor encontrado para a relação entre as massas dos agregados, em porcentagem, é o parâmetro considerado pela NBR 15823-1:2017 na determinação da classe de resistência à segregação de acordo com a Tabela 3.10 (ABNT, 2017a).

Tabela 3.10 - Classes de resistência à segregação pela coluna de segregação.

\begin{tabular}{cc}
\hline Classe & Coluna de segregação (\%) \\
\hline$S R 1$ & $\leq 20$ \\
$S R 2$ & $\leq 15$ \\
\hline Fonte: NBR $15823-1: 2017$ (ABNT,2017a).
\end{tabular}

Fonte: NBR 15823-1:2017 (ABNT,2017a). 
Figura 3.23 - Coluna de segregação. Dimensões em milímetros.

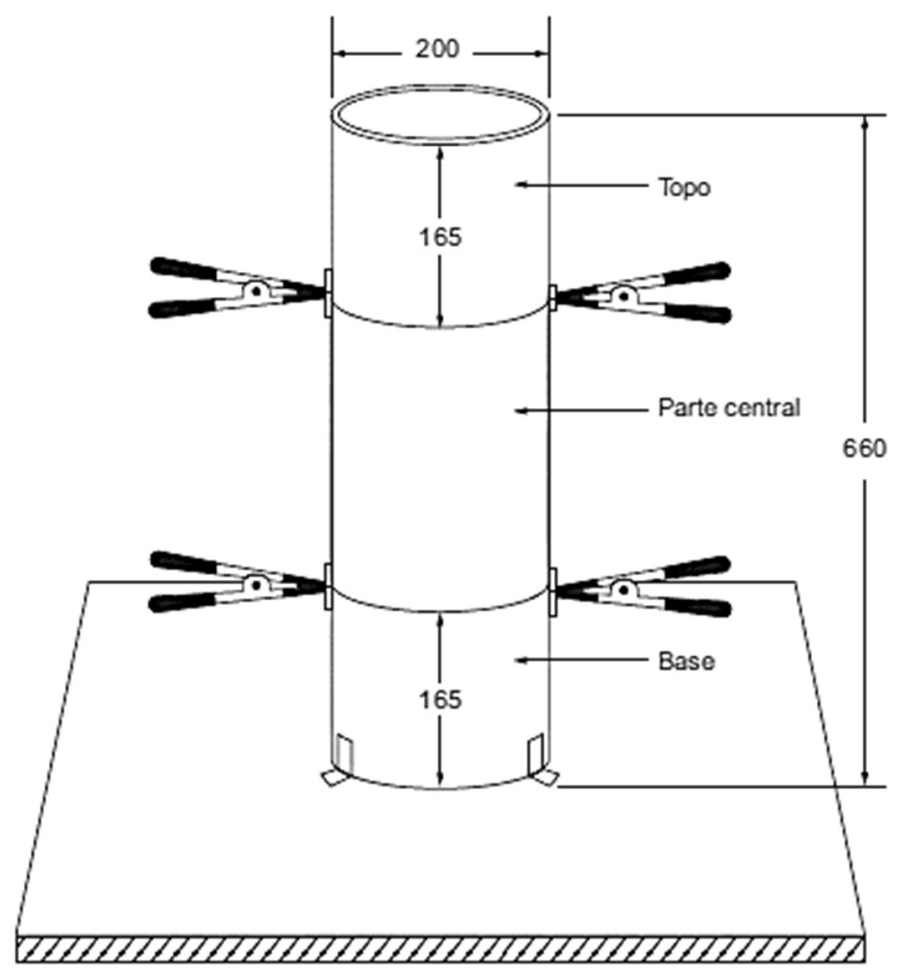

Fonte: NBR 15823-6:2017 (ABNT, 2017f).

Figura 3.24 - Ensaio de coluna de segregação em andamento.

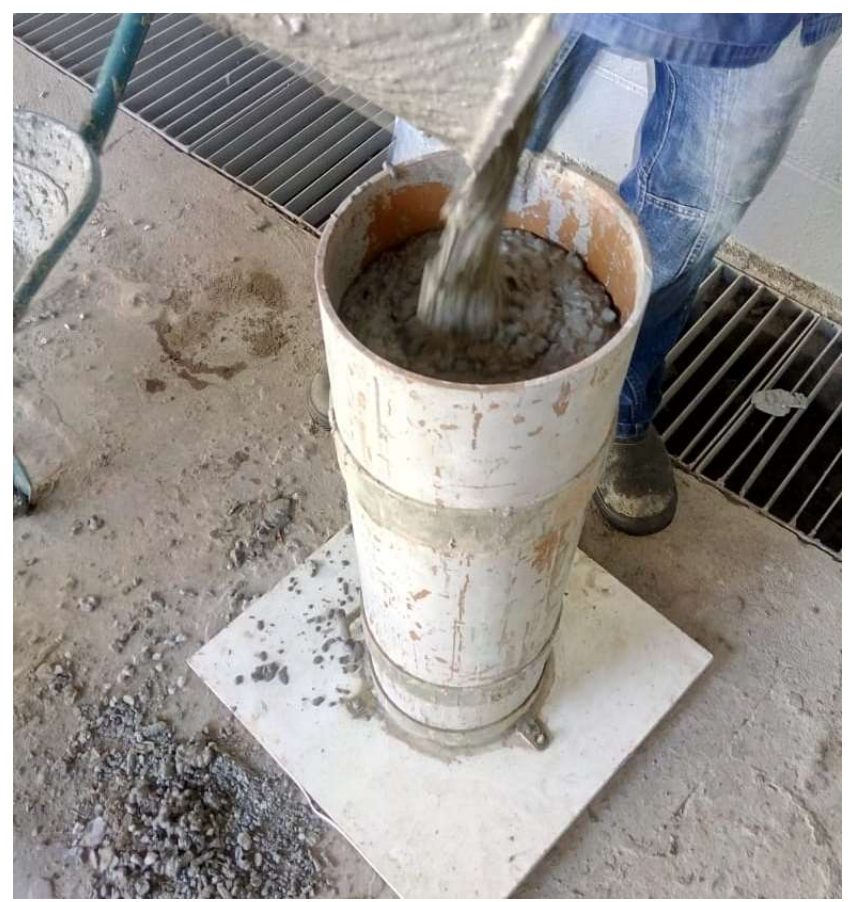

Fonte: Arquivo Pessoal. 
O Anexo A da NBR 15823-1:2017 recomenda que para "pilares, paredes e elementos estruturais complexos" seja utilizado concreto de SR 2 (ABNT, 2017a). Portanto, o presente trabalho deve apresentar traços que apresentem resistência à segregação do concreto inferior a $15 \%$.

Vale aqui a observação de que, assim como no caso da classe de espalhamento, Costa e Lima (2018) apresentam uma obra que indica classe de resistência à segregação $S R 1$ para o concreto autoadensável utilizado, diferente do que foi definido neste trabalho.

\subsubsection{Determinação do teor de ar incorporado ao concreto}

O teor de ar incorporado é determinado de acordo com a NBR 9833:2008 Concreto fresco - Determinação da massa específica, do rendimento e do teor de ar pelo método gravimétrico (ABNT, 2008b). O método indicado por essa norma está apresentado na sequência.

Inicialmente deve ser calculada a massa específica aparente $\left(\rho_{a p}\right)$ do concreto, definida pela razão entre massa e volume com aproximação de $1 \mathrm{~kg} / \mathrm{m}^{3}$. Na sequência, deve ser definido o rendimento desse concreto, dado pela razão entre a soma das massas $(\mathrm{kg})$ dos materiais utilizados na betonada e a massa específica aparente do concreto $\left(\mathrm{kg} / \mathrm{m}^{3}\right)$. Em seguida, deve ser calculado o volume total dos componentes da betonada, definido pela soma das razões entre as massas $(\mathrm{kg})$ de cada material e suas respectivas massas específicas $\left(\mathrm{kg} / \mathrm{m}^{3}\right)$. Os valores de rendimento e volume total dos componentes da betonada são utilizados na determinação do índice de ar $\left(I_{a}\right)$ simplesmente ao se fazer a razão dos dois. Por fim, o teor de ar $(A)$, com aproximação de $0,1 \%$, é definido pela Equação 9.

$$
A=\left(1-\frac{1}{I_{a}}\right) \cdot 100
$$

A NBR 16055:2012 não especifica um valor limite para a porcentagem de ar incorporado ao concreto, o que acaba gerando incertezas em relação aos valores que devem ser considerados para dosagem do concreto empregado na execução de paredes moldadas no local. Segundo Comunidade da Construção (2007/2008), é considerado o valor de 9\% para o teor de ar em concretos descritos como sendo de alto teor de ar incorporado. Para este trabalho, serão considerados dois teores diferentes para o ar incorporado, sendo um deles esse valor de $9 \%$ e o outro teor referente a uma extrapolação desse limite, fixado em 15\%. 


\subsection{Medição das propriedades do concreto endurecido}

\subsubsection{Ensaio de compressão de corpos de prova cilíndricos}

Esse é um dos ensaios mais simples de ser executado e apresenta resultado que pode ser considerado, na maioria das vezes, o mais importante: a resistência à compressão do concreto. No Brasil, esse ensaio é regulamentado pela NBR 5739:2007-Concreto - Ensaio de compressão de corpos-de-prova cilíndricos (ABNT, 2007).

Em termos de resistência à compressão, a NBR 16055:2012 não cita diretamente qual o valor mínimo a ser considerado para as paredes de concreto, mas faz algumas referências que permitem defini-lo (ABNT, 2012b). Indica-se que em termos de durabilidade das estruturas, devem ser respeitadas as exigências da NBR 6118:2014 - Projeto de estruturas de concreto - Procedimento (ABNT, 2014a), com valores iguais aos apresentados nas Tabelas 5 e 6 da referida norma, que relacionam a classe de agressividade ambiental com a classe de resistência mínima a ser considerada para o concreto.

Como indicado anteriormente, considera-se que as construções em paredes de concreto moldadas no local se encontram em ambiente urbano, o que significa que a classe do concreto utilizado deve ser no mínimo C25. Entretanto, a NBR 16055:2012 faz uma ressalva de que no caso do uso de armaduras centradas com cobrimentos maiores que o especificado pela NBR 6118:2014, pode-se utilizar as prescrições de uma classe de agressividade ambiental imediatamente acima (mais branda), desde que se verifique o estado-limite de abertura de fissuras em uma eventual face tracionada (ABNT, 2012b). Dessa forma, é possível considerar que a resistência mínima característica à compressão para paredes de concreto armado é de $20 \mathrm{MPa}$ aos 28 dias de idade (C20). Em relação ao limite superior de resistência, a NBR 16055:2012 estabelece que a resistência característica à compressão não pode ser considerada superior a $40 \mathrm{MPa}$ (ABNT, 2012b). Assim, no presente trabalho foram adotadas duas classes de resistência para os concretos produzidos: C25, isto é, resistência à compressão de $25 \mathrm{MPa}$ aos 28 dias de idade, de acordo com o requisito de durabilidade do concreto em função da classe de agressividade ambiental; e C40, isto é, resistência característica à compressão de $40 \mathrm{MPa}$ aos 28 dias de idade, atendendo ao valor máximo de resistência especificado na normalização brasileira de paredes de concreto.

Outro valor de interesse para o projeto de paredes de concreto é a resistência à compressão para desforma que, assim como descrito pela NBR 16055:2012, deve ser 
compatível com o ciclo de concretagem (ABNT, 2012b). Porém, não são definidas nem a idade, nem a resistência à compressão mínima, ficando essa escolha a cargo do projetista.

Ainda assim, esses valores são disponibilizados na literatura e podem auxiliar na definição de um valor a ser considerado para essa resistência no presente trabalho. Em Comunidade da Construção (2007/2008), a desforma acontece 14 horas após a concretagem ou conforme o ciclo considerado; segundo Comunidade da Construção (2009/2010) a desforma também deve ocorrer após 14 horas da concretagem, devendo ser respeitada uma resistência à compressão mínima de 3,5 MPa nessa idade; a diretriz SINAT 004 (2011) consiste na avaliação técnica de uma obra na qual foi considerada a desforma após 14 horas, com resistência à compressão mínima de 3,0 MPa; em Sacht e Rossignolo (2008) é considerado que a resistência à compressão entre 8 e 12 horas deve ser maior que 1,0 MPa para permitir a desforma sem danificar os painéis utilizados; já em Silva (2011), a resistência mínima do concreto na desforma, após 15 horas, é considerada como 1,8 MPa; Costa e Lima (2018) apresentam resistência de desforma maior ou igual a $3 \mathrm{MPa}$ após 12 horas em uma obra executada na cidade de São Paulo.

Em visita técnica realizada na cidade de São Carlos/SP durante o desenvolvimento desse trabalho, observou-se projeto com resistência de desforma mínima de $3 \mathrm{MPa}$, porém sem definição do tempo para a desforma. Nessa visita ficou evidenciado que o tempo para desforma é dependente do ciclo da construção, ou seja, as fôrmas são retiradas no momento em que for possível a continuidade de outras etapas. No caso da obra em questão, a cada dois dias é concretado um pavimento inteiro. Dessa forma, metade de um pavimento é concretada em um dia, enquanto a outra metade é concretada no dia seguinte. Quando os trabalhos de armação com telas e de instalações hidráulicas e elétricas são finalizados em uma metade, as fôrmas são posicionadas e é realizada concretagem ao final do dia. No dia seguinte, as fôrmas são retiradas para dar prosseguimento às instalações necessárias. Portanto, o tempo de desforma adotado nessa obra foi de 14 horas, tempo necessário para que sejam realizados os procedimentos que antecedem o remanejamento das fôrmas utilizadas.

A partir do exposto, considerou-se, neste trabalho, considerar um tempo de desforma igual a 12 horas e resistência à compressão, para essa idade, maior ou igual a $3 \mathrm{MPa}$.

Para a execução do ensaio de determinação da resistência à compressão, as características dos corpos de prova utilizados no ensaio, bem como o procedimento de cura adotado devem ser definidos de acordo com a NBR 5738:2015 - Concreto-Procedimento para moldagem e cura de corpos de prova (ABNT, 2015a). No presente trabalho foram realizados ensaios em corpos de prova cilíndricos com dimensões de $100 \mathrm{~mm}$ de diâmetro e $200 \mathrm{~mm}$ de 
altura. Com relação à cura, os corpos de prova foram mantidos em câmara úmida até as respectivas idades de ensaio.

Os corpos de prova foram ensaiados nas primeiras idades com 12, 15, 18, $21 \mathrm{e}$ 24 horas, e aos 7 e 28 dias. Foram consideradas 3 amostras para cada idade de cada traço proposto, com exceção de 28 dias, idade na qual foram ensaiados 5 corpos de prova. Dessa forma, considerando-se as idades de ruptura e ainda os seis traços produzidos, foram utilizados 138 corpos de prova cilíndricos para os ensaios de compressão.

\subsubsection{Determinação da resistência à tração por compressão diametral de corpos de prova cilíndricos}

A NBR 16055:2012 não apresenta limite mínimo para a resistência à tração do concreto utilizado na construção de paredes de concreto moldadas no local. Ainda assim, o presente projeto consiste no desenvolvimento de traços de concreto para aplicação específica, sendo importante o conhecimento do comportamento do material de uma maneira mais completa. Portanto, a determinação da resistência à tração se encontra no escopo deste trabalho.

No Brasil, a norma que regulamenta o ensaio de tração por compressão diametral é a NBR 7222:2011 - Concreto e argamassa - Determinação da resistência à tração por compressão diametral de corpos de prova cilíndricos (ABNT, 2011). Os corpos de prova cilíndricos devem ser posicionados horizontalmente em uma máquina de ensaio que aplicará força diametralmente.

A resistência à tração por compressão diametral deve ser calculada, segundo a NBR 7222:2011, em função da força máxima obtida no ensaio e das dimensões do corpo de prova ensaiado (ABNT, 2011).

Em relação às dimensões dos corpos de prova, foram utilizados corpos de prova cilíndricos, com $100 \mathrm{~mm}$ de diâmetro e $200 \mathrm{~mm}$ de altura. Foram realizados ensaios de tração por compressão diametral aos 28 dias de idade em cada um dos seis traços produzidos, sendo ensaiados 3 corpos de prova por traço, resultando em um total de 18 corpos de prova.

\subsubsection{Determinação da resistência à tração na flexão de corpos de prova prismáticos}

Outro método para se determinar a resistência à tração do concreto é por meio de ensaio de flexão em corpos de prova prismáticos, regulamentado pela NBR 12142:2010 Concreto - Determinação da resistência à tração na flexão de corpos de prova prismáticos 
(ABNT, 2010a). O ensaio consiste basicamente no princípio de uma viga simplesmente apoiada com aplicação de forças concentradas nos terços do vão.

Ainda segundo a NBR 12142:2010, deve-se aplicar força de maneira contínua, de forma que seja mantido um intervalo de tensão sobre o corpo de prova entre $0,9 \mathrm{MPa} / \mathrm{min}$ a 1,2 $\mathrm{MPa} / \min$ (ABNT, 2010a). A resistência à tração é calculada a partir das dimensões do prisma ensaiado e também da força máxima registrada no ensaio.

Na presente pesquisa foram utilizados corpos de prova prismáticos, com dimensões vertical e horizontal iguais a $150 \mathrm{~mm}$ e comprimento de $500 \mathrm{~mm}$. Foi considerado ainda o ensaio de tração na flexão realizado em 3 corpos de prova prismáticos com idade de 28 dias para cada um dos seis traços produzidos, totalizando 18 corpos de prova ensaiados.

\subsubsection{Determinação do módulo de elasticidade dinâmico}

A NBR 16055:2012 não trata o módulo de elasticidade como obrigatório, e sim como um requisito complementar que poderia ser solicitado pelo projetista (ABNT, 2012b). Ainda assim, como comentado para os ensaios de tração, é importante conhecer de maneira mais ampla o comportamento do material, dado que este trabalho possui aplicação prática.

No presente estudo foi determinado o módulo de elasticidade dinâmico em corpos de prova prismáticos, com dimensões de $150 \mathrm{~mm}$ x $150 \mathrm{~mm}$ x $500 \mathrm{~mm}$. Conforme apresentado em Otani e Pereira (2017), esse ensaio foi baseado na Técnica de Excitação por Impulso presente na ASTM E 1876 (ASTM, 2015). Com essa técnica, é possível a caracterização dos módulos elásticos a partir do modo de vibração aplicado. Sendo assim, além do módulo de elasticidade, o ensaio foi utilizado também na determinação do módulo de cisalhamento e do coeficiente de Poisson.

O modulo de elasticidade dinâmico é determinado a partir da frequência de ressonância nos modos de vibração flexional ou longitudinal. O módulo de cisalhamento dinâmico é encontrado utilizando vibrações ressonantes torcionais. Os módulos dinâmicos de elasticidade e de cisalhamento são usados para definir o coeficiente de Poisson (ASTM, 2015). 
Para a realização do ensaio, foi utilizado o sistema Sonelastic ${ }^{5}$, que consiste em um pulsador para excitar a amostra sem gerar ruído, um captador acústico para detectar a resposta acústica do prisma analisado, e o software Sonelastic que processa a resposta acústica e calcula os módulos elásticos e o amortecimento de acordo com a norma ASTM E 1876 (ASTM, 2015).

Nesse ensaio, o prisma a ser analisado é posicionado sobre molas com o objetivo de não restringir a vibração. Na sequência, o pulsador é utilizado para vibrar o prisma, com obtenção da resposta por meio do captador acústico. Os posicionamentos do captador e da excitação por meio do pulsador definem quais os módulos elásticos serão captados pelo software. As Figuras 3.25 a 3.27 apresentam as diferentes posições consideradas neste trabalho, enquanto a Figura 3.28 exemplifica o esquema de posicionamento para vibração flexional.

Figura 3.25 - Posicionamentos do pulsador e do captador para obtenção do módulo de elasticidade a partir de vibração flexional.

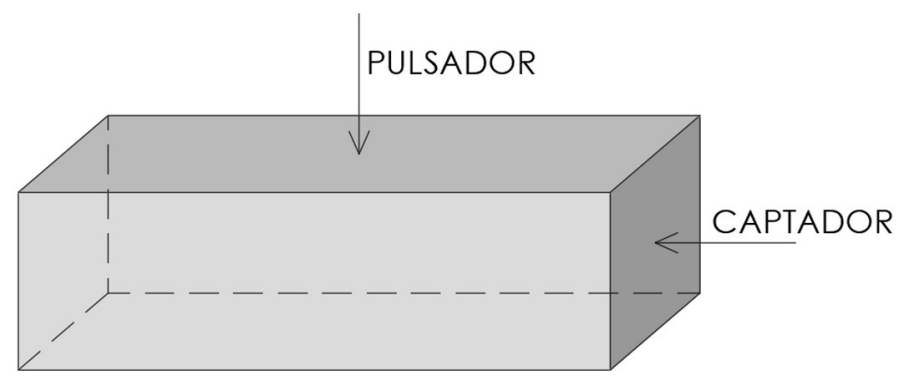

Fonte: Elaborado pelo autor.

Figura 3.26 - Posicionamentos do pulsador e do captador para obtenção do módulo de elasticidade a partir de vibração longitudinal.

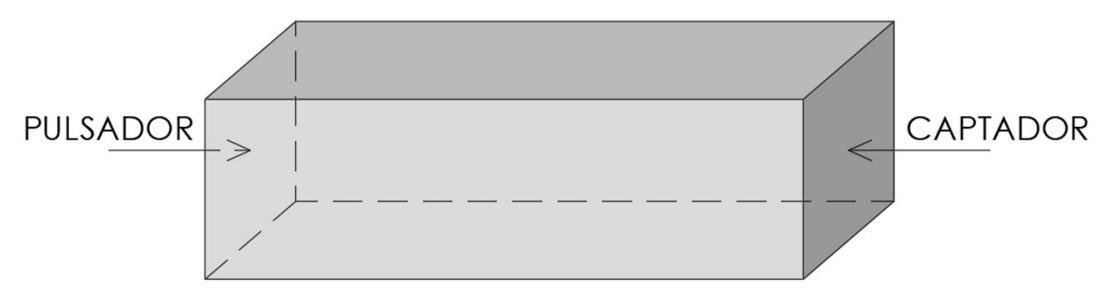

Fonte: Elaborado pelo autor.

\footnotetext{
5 SONELASTIC. Caracterização do módulo de elasticidade de concretos, materiais cimentícios e rochas. Disponível em <https:/www.sonelastic.com/pt/aplicacoes/concretos-cimenticios $>$ acesso em: 08 de março de 2019.
} 
Figura 3.27 - Posicionamentos do pulsador e do captador para obtenção do módulo de elasticidade, módulo de cisalhamento e coeficiente de Poisson a partir de vibração torcional.

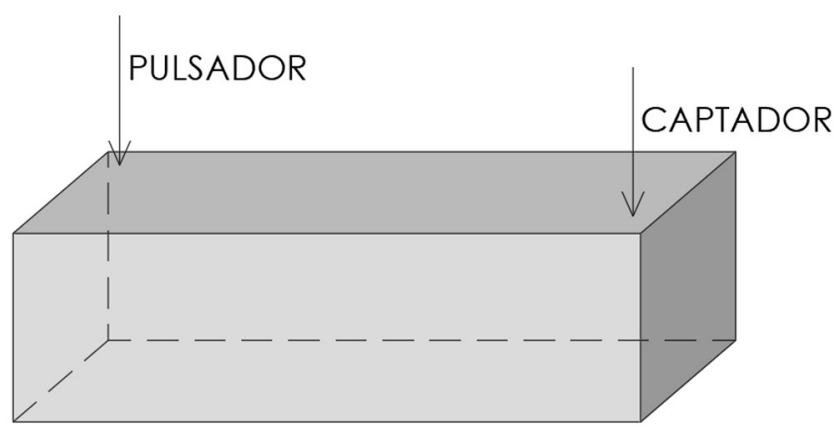

Fonte: Elaborado pelo autor.

Figura 3.28 - Exemplo do método de obtenção do módulo de elasticidade a partir de vibração flexional.

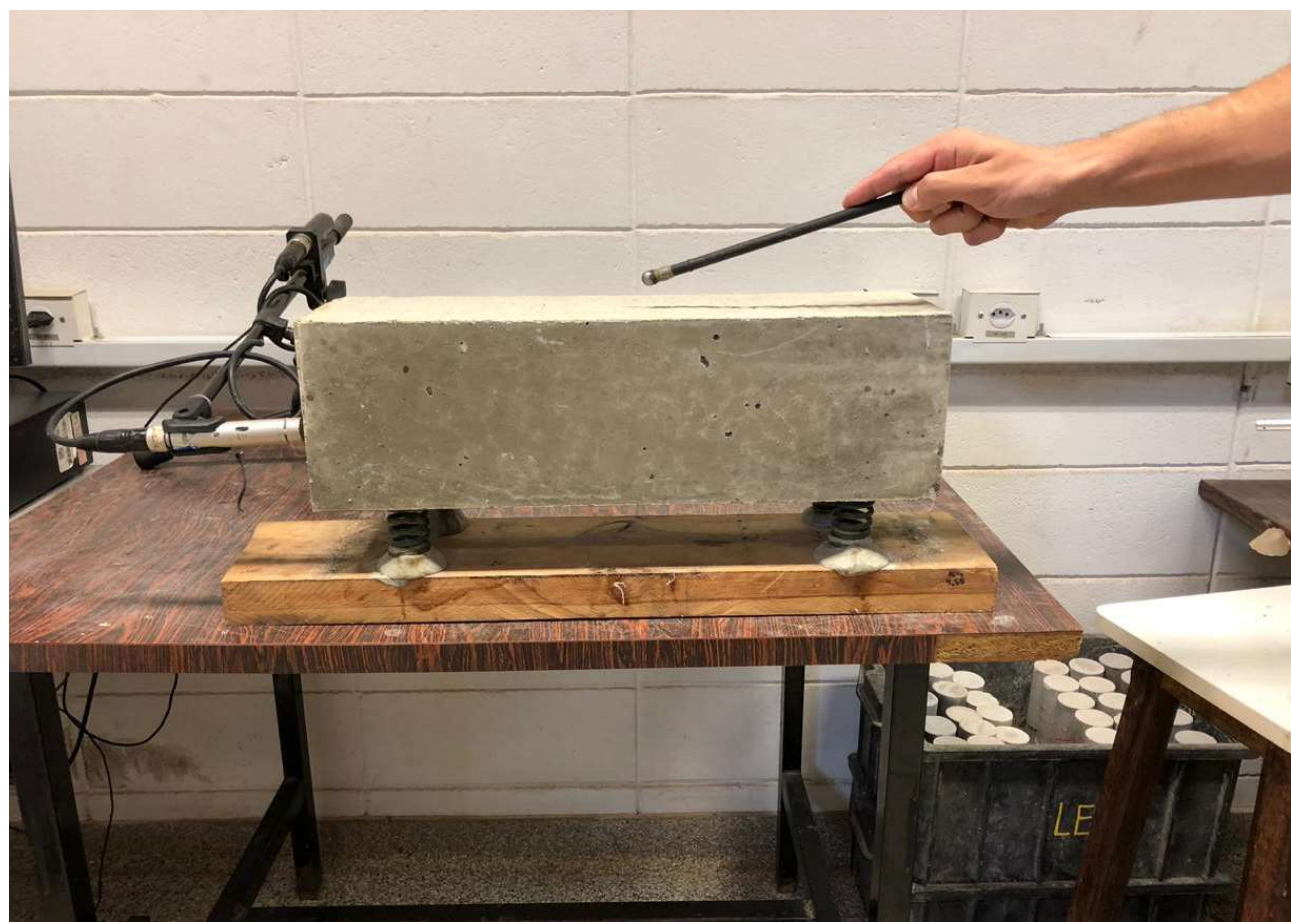

Fonte: Arquivo pessoal.

Os ensaios nos prismas foram realizados nas mesmas datas que os ensaios de resistência à compressão, isto é, nas idades de 12,15, 18, 21 e 24 horas, e 7 e 28 dias, sendo considerados 3 prismas para todas as idades. Com isso, foi possível a comparação da evolução da resistência à compressão com os módulos elásticos obtidos com o Sonelastic. 


\subsubsection{Ensaio de ultrassom em prismas}

Outro ensaio realizado nos prismas foi o de ultrassom. Segundo NBR 8802:2019 Concreto endurecido - Determinação da velocidade de propagação de onda ultrassônica, esse é um ensaio não-destrutivo que tem o objetivo de determinar a velocidade de propagação de ondas, obtidas por pulsos ultrassônicos, em concreto (ABNT, 2019). De acordo com ASTM C 597 (ASTM, 2016), o ensaio permite determinar a uniformidade e a qualidade relativa do concreto com base na velocidade de propagação do som por seu interior.

O equipamento utilizado deve possuir um circuito gerador-receptor de pulso, um par de transdutores (sendo um transmissor e um receptor), um circuito para medição do tempo e cabos conectores (ABNT, 2019). O esquema do equipamento está apresentado na Figura 3.29.

Figura 3.29 - Esquema do equipamento para medição de pulso.

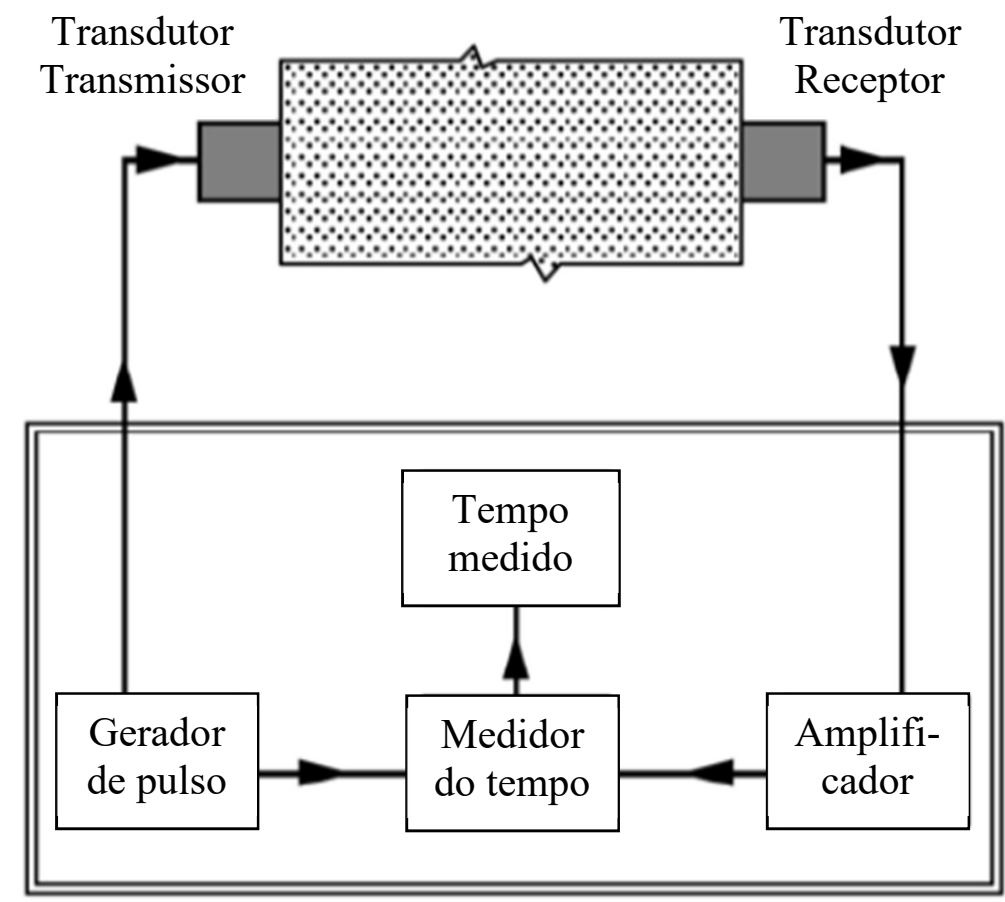

Fonte: Adaptado de ASTM C597 (2016).

Nessa pesquisa, foi utilizado um equipamento certificado para ensaio ultrassônico denominado Pundit Lab da empresa Proceq ${ }^{6}$. Foram considerados transdutores de $54 \mathrm{kHz}$ que eram posicionados longitudinal e transversalmente opostos, centrados nas faces analisadas

\footnotetext{
6 PUNDIT $\quad$ LAB. $\quad$ Certificado de $\quad$ Origem. Disponível em $<$ https://www.proceq.com/uploads/tx_proceqproductcms/import_data/files/Pundit\%20Lab_Certificates_Multiling ual_high.pdf > acesso em: 08 de março de 2019.
} 
(Figura 3.30). Assim, as medições eram realizadas com distâncias de $500 \mathrm{~mm}$ e $150 \mathrm{~mm}$, sendo possível uma comparação da velocidade do pulso nas duas direções.

Figura 3.30 - Exemplo do método de obtenção de velocidades para pulso ultrassônico na direção longitudinal de prisma de concreto.

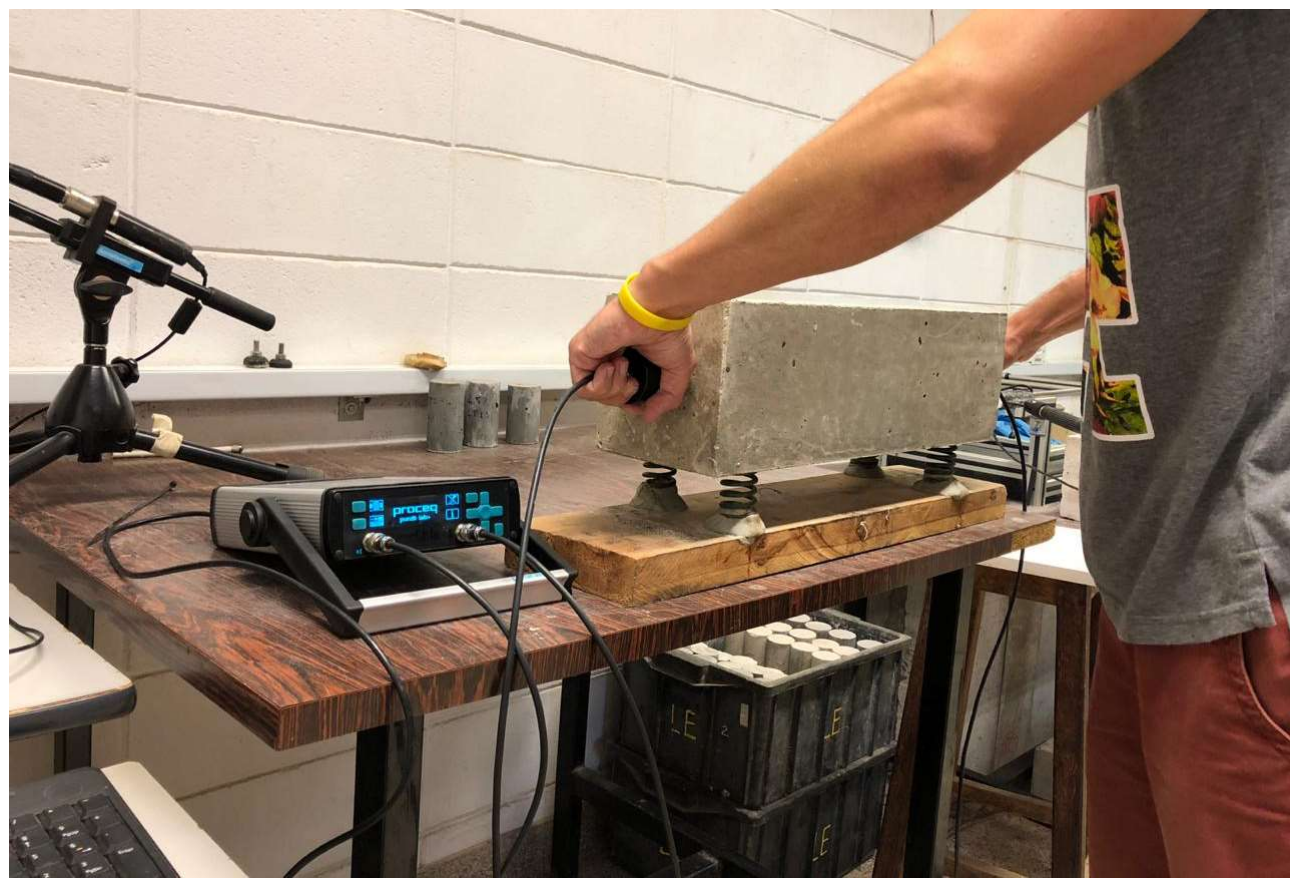

Fonte: Arquivo pessoal.

Porém, a análise da velocidade do pulso ultrassônico em concreto de maneira isolada pode não definir um valor, por si só, representativo, sendo necessária sua comparação com outras propriedades. Isso acontece porque, como mostrado em Garnier, Chaix e Corneloup (2009), a velocidade é uma função do módulo de compressibilidade, do módulo de cisalhamento e da densidade do material, propriedades afetadas, por exemplo, pela porosidade e quantidade de fissuras no concreto.

Segundo Saint-Pierre et al. (2016), o fato de diferentes misturas de concreto apresentarem diferentes densidades (a depender, por exemplo, da quantidade de ar incorporado ou da densidade do agregado utilizado) explica porque a velocidade do pulso ultrassônico pode variar entre as estruturas, ainda que o concreto não exiba sinais de danos. De maneira geral, Feldman (1977) afirma que velocidades de onda mais alta são um indicativo de boa qualidade do concreto.

A NBR 8022:2019 define os principais fatores que influenciam nos resultados do ensaio (ABNT, 2019), a saber: 
- Distância entre as superfícies de contato dos transdutores;

- Presença de armadura, principalmente na direção de propagação da onda;

- Densidade do concreto, que depende do traço e das condições de concretagem;

- Tipo, densidade e outras características dos agregados;

- Tipo de cimento e grau de hidratação;

- Direção de ensaio da peça;

- Tipo de adensamento do concreto;

- Idade do concreto;

- Umidade do concreto;

- Temperatura do concreto;

- Forma e tamanho da peça a ser ensaiada.

Apesar da grande variedade de fatores que interferem na velocidade observada, Leslie e Cheeseman $(1947)^{7}$ apud Feldman (1977) apresentam uma relação geral entre a qualidade do concreto e a velocidade do pulso ultrassônico (Tabela 3.11).

Tabela 3.11 - Condição geral do concreto em função da velocidade de pulso ultrassônico.

\begin{tabular}{ccc}
\hline Condição geral & \multicolumn{2}{c}{ Velocidade do pulso ultrassônico } \\
\cline { 2 - 3 } do concreto & ft/s & m/s \\
\hline Excelente & $>15000$ & $>4572$ \\
Boa & 12000 a 15000 & 3658 a 4752 \\
Questionável & 10000 a 12000 & 3048 a 3658 \\
Ruim & 7000 a 10000 & 2134 a 3048 \\
Muito ruim & $<7000$ & $<2134$ \\
\hline Nota: & \\
ft/s $=$ pés/segundo
\end{tabular}

Feldman (1977) destaca que, devido a interferências na velocidade causadas pela presença de aço no concreto, é desejado e aconselhado que os caminhos de medição escolhidos evitem a influência de barras de armação.

Em relação aos valores apresentados na Tabela 3.11, Saint-Pierre et al. (2016) fazem uma ressalva de que o método é questionável para estruturas com grande massa de

${ }^{7}$ LESLIE, J. R.; CHEESEMAN, W. J. An ultrasonic method for studying deterioration and cracking in concrete structures, ACI Mater. v. 46. 1949. p. 17-36. 
concreto, como por exemplo barragens. Como esse não é o caso do presente trabalho, considera-se que os intervalos de velocidade apresentados servirão de auxílio na determinação da qualidade do concreto.

Naik, Malhotra e Popovics (2004) também apresentam uma escala de comparação entre velocidades do pulso ultrassônico em concreto. A Tabela 3.12 apresenta as correlações, que consideram concreto não armado. Os valores indicados apresentam apenas 3 variações da qualidade do concreto, mas ajudam a reforçar os valores apresentados na Tabela 3.11.

Tabela 3.12 - Qualidade do concreto em função da velocidade de pulso ultrassônico.

Condição geral do concreto Velocidade do pulso ultrassônico (m/s)

\begin{tabular}{cc}
\hline Muito boa & 5000 \\
Média & 4000 \\
Muito ruim & 3000 \\
\hline Fonte: Adaptado de Naik, Malhotra e Popovics (2004).
\end{tabular}

No presente trabalho, os corpos de prova prismáticos, com dimensões de $150 \mathrm{~mm}$ x $150 \mathrm{~mm}$ x $500 \mathrm{~mm}$, foram ensaiados com aparelho de ultrassom logo na sequência do ensaio de determinação dos módulos de elasticidade dinâmicos. Portanto, os ensaios foram realizados nas idades de $12,15,18,21$ e 24 horas, e 7 e 28 dias, sendo considerados 3 prismas para todas as idades. Considerando essas idades de ensaio, foi possível fazer uma comparação ao longo do tempo dos valores da velocidade do pulso ultrassônico pelo concreto com os valores de resistência à compressão e módulos dinâmicos.

\subsubsection{Análises estatísticas}

Foram feitas análises estatísticas para parâmetros de interesse obtidos a partir dos ensaios em concreto endurecido. Foi utilizado Critério de Chauvenet para verificar a necessidade de descarte de algum resultado obtido com os ensaios de resistência à compressão, e resistências à tração por compressão diametral e na flexão realizados aos 28 dias de idade. Foi realizado ainda teste $\mathrm{t}$ de Student para identificar se existe diferença significativa entre os valores de resistências à compressão, tração na compressão diametral e tração na flexão, módulo de elasticidade dinâmico e velocidade do pulso ultrassônico para concretos de diferentes traços analisados aos 28 dias. Os resultados estão apresentados nos Anexos B até D. 


\subsection{Moldagem de paredes de concreto}

Outra etapa deste trabalho consiste na moldagem de modelos de paredes de concreto para posterior avaliação do acabamento superficial por imagens e análise da estrutura interna com equipamento de ultrassom. Para isso, pensou-se, inicialmente, em moldar modelos em escala reduzida, pois paredes com grandes dimensões poderiam se tornar inviáveis em termos logísticos para concretagem em laboratório. Mas essa hipótese foi descartada ao avaliar que uma redução nas proporções da parede afetaria o comportamento do concreto em comparação com escala real.

Com os modelos em escala reduzida descartados, decidiu-se por realizar as concretagens utilizando fôrmas comerciais, de maneira que fosse possível garantir a estabilidade do conjunto, reduzindo as possibilidades de acidentes durante a concretagem. Sendo assim, as dimensões das paredes passaram a ser dependentes das dimensões dos painéis disponíveis no mercado.

Ao consultar catálogos de algumas empresas, os painéis com $1,50 \mathrm{~m}$ por $0,75 \mathrm{~m}$ se mostraram interessantes, pois seria possível a concretagem de paredes com 1,50 $\mathrm{m}$ de altura por 1,50 m de largura, dimensões que permitiriam a concretagem em laboratório. Optou-se por espessura de $10 \mathrm{~cm}$, por ser essa a espessura mínima definida na NBR 16055:2012 para paredes com altura de até $3 \mathrm{~m}$ (ABNT, 2012b). Considerou-se que essas dimensões seriam representativas de uma parede real, principalmente pela manutenção de uma espessura usual.

Definidas as dimensões, foram contatadas algumas empresas da região que pudessem fornecer os painéis para moldagem, sendo os painéis e outros equipamentos necessários para a montagem das fôrmas disponibilizados pela empresa ULMA. Os painéis utilizados são do modelo $\mathrm{COMAIN}^{8}$ e consistem em placas com estrutura metálica e tampo em chapa de madeira. Cada módulo de $1,50 \mathrm{~m}$ por $0,75 \mathrm{~m}$ pesa cerca de $35 \mathrm{~kg}$, o que permite o manuseio e montagem por apenas uma pessoa. Na sequência são apresentadas imagens de vista lateral e frontal presentes no projeto personalizado fornecido pela empresa ULMA em comparação com os painéis montados no laboratório de estruturas da EESC-USP (Figuras 3.31 a 3.34).

\footnotetext{
${ }^{8}$ ULMA. Forma para Concreto COMAIN Disponível em $<$ https://www.ulmaconstruction.com.br/pt-br/formas-eescoramentos/formas-paredes-pilares/forma-concreto-comain> acesso em: 08 de março de 2019.
} 
Figura 3.31 - Vista lateral do posicionamento das fôrmas em projeto.

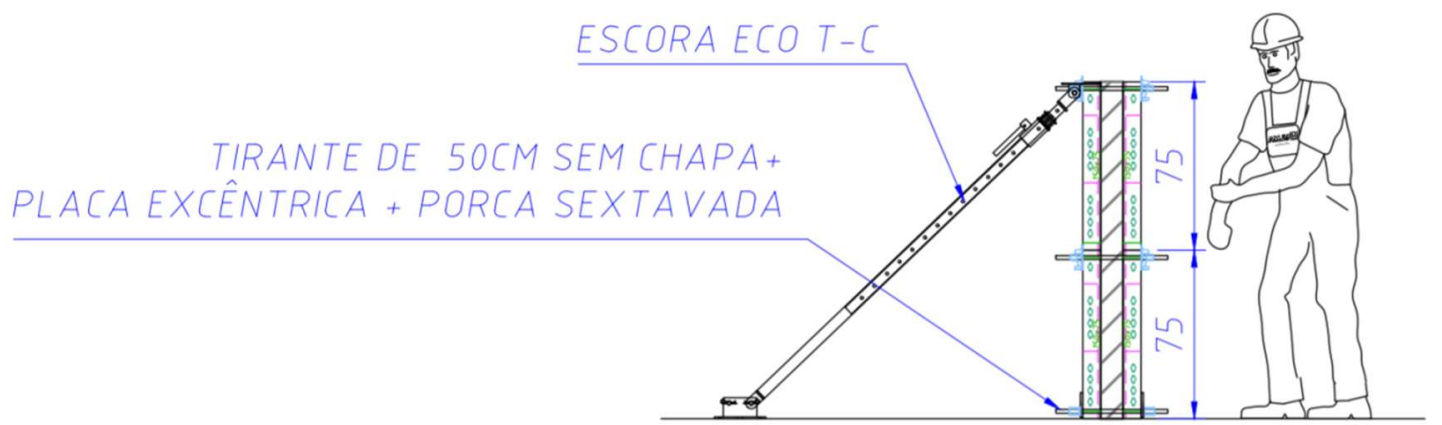

Fonte: Projeto de montagem das fôrmas fornecido pela empresa ULMA.

Figura 3.32 - Vista lateral do posicionamento das fôrmas em laboratório.

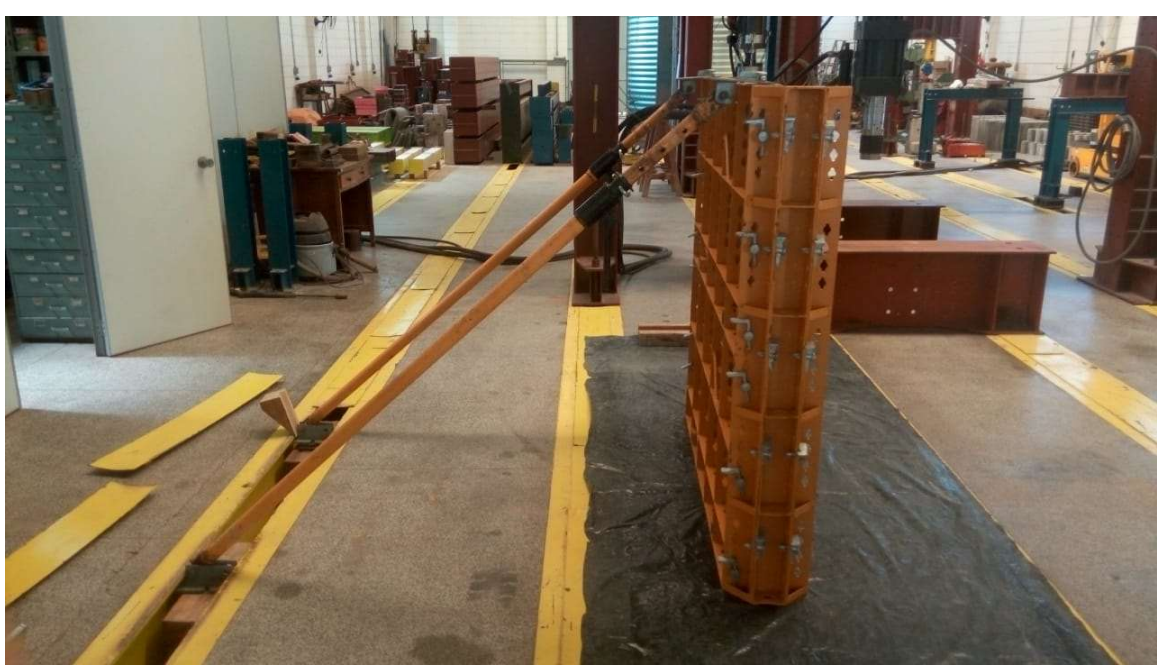

Fonte: Arquivo pessoal.

Figura 3.33 - Vista frontal do posicionamento das fôrmas em projeto.

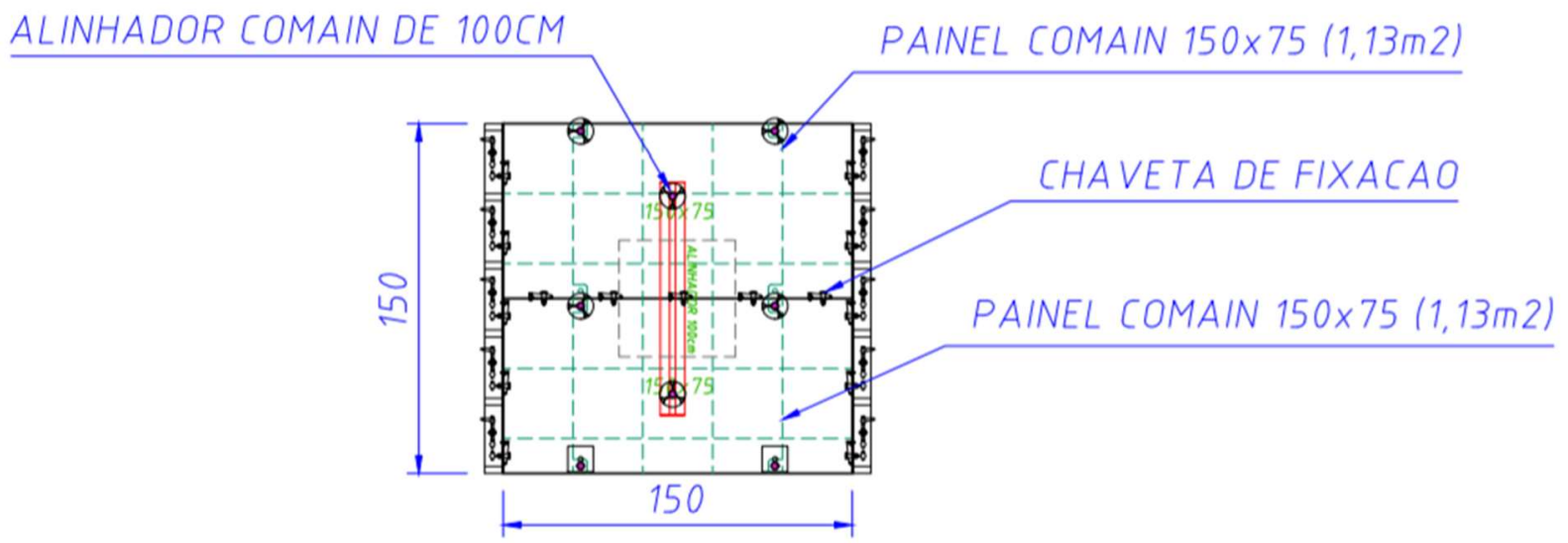

Fonte: Projeto de montagem das fôrmas fornecido pela empresa ULMA. 
Figura 3.34 - Vista frontal do posicionamento das fôrmas em laboratório.

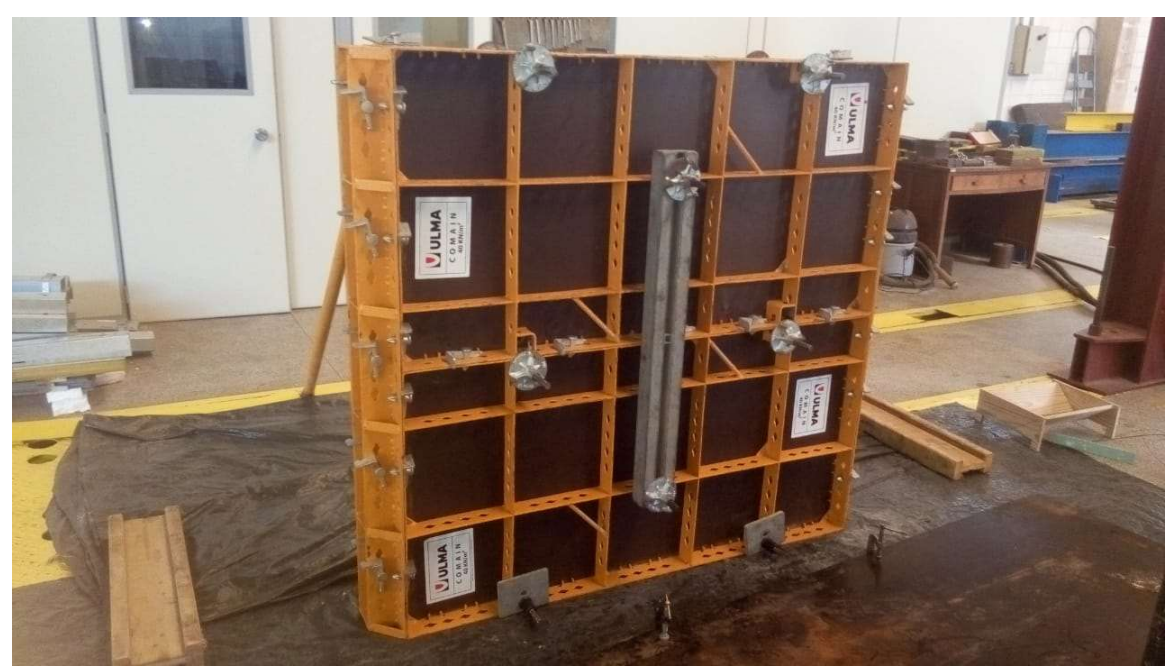

Fonte: Arquivo pessoal.

Outro ponto importante para justificar a confecção dessas paredes é avaliar os possíveis problemas relacionados ao preenchimento dos concretos autoadensáveis definidos nessa pesquisa. Optou-se, então, por considerar uma janela no centro da parede com dimensões de $0,50 \mathrm{~m}$ por $0,50 \mathrm{~m}$. Dessa forma, foi introduzido um obstáculo para a concretagem que geraria cantos vivos, representando um desafio para o preenchimento. O molde da janela foi feito em madeira e fixado na posição correta entre as fôrmas por meio de arames metálicos. $\mathrm{O}$ esquema da parede a ser concretada está apresentado na Figura 3.35.

Figura 3.35 - Esquema da parede a ser concretada.

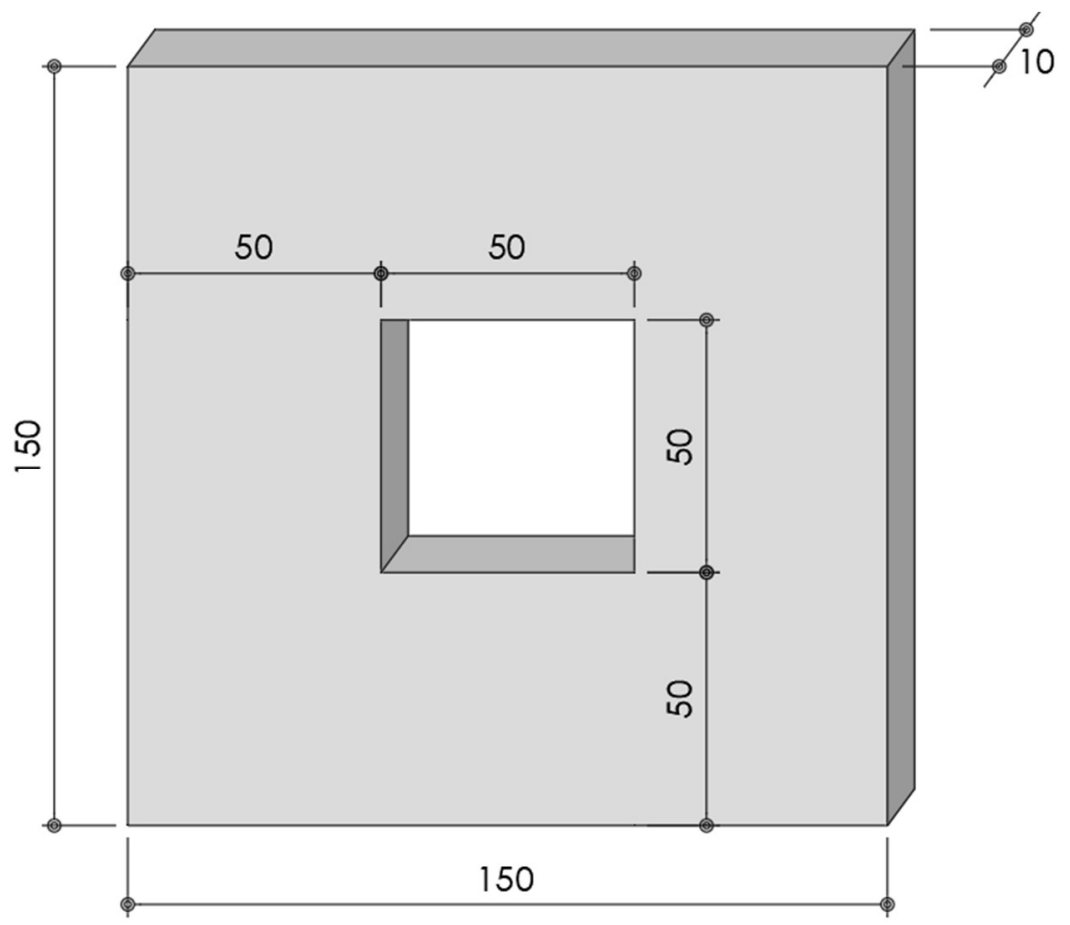

Fonte: Elaborado pelo autor. 
Decidiu-se, também, que não seriam utilizados elementos que simulassem as instalações hidráulicas e elétricas, como conduítes e tubulações. Isso foi adotado porque essas instalações acarretariam um grau de dificuldade elevado para um modelo de parede isolado e executado em laboratório, além de considerar-se que a janela seria um obstáculo de maior desafio para o adensamento e o preenchimento por parte do concreto.

Também não foi considerado nenhum tipo de armação com tela, pois os fios horizontais da tela poderiam afetar os resultados da análise com equipamento de ultrassom que será apresentado mais à frente. Isso porque, de acordo com ASTM C 597 (ASTM, 2016), a velocidade de propagação do som no aço é de até duas vezes a de propagação no concreto, sendo assim, é recomendada a não medição da propagação do som em direção paralela ao posicionamento do aço.

\subsection{Avaliação do acabamento superficial para os traços definidos}

A partir dos painéis de parede concretados, foram realizadas análises do acabamento superficial do concreto. A análise foi viabilizada por meio do uso de software de análise e tratamento de imagem Image $^{9}$ e seguiu como base um dos métodos de análise propostos por Benito et al. (2015). A escolha desse software para a análise do acabamento superficial no presente trabalho foi feita por se tratar de um programa de processamento de imagem de código aberto, permitindo sua utilização de forma gratuita.

O método consiste em importar as imagens da superfície do concreto para o programa ImageJ e na sequência ajustá-las para 8 bits, nas cores preta e branca, destacando as imperfeições da superfície. A imagem deve então ser corrigida com balanço de cores de maneira a definir as regiões de falhas na cor preta e as regiões íntegras com a cor branca (BENITO et al., 2015). Vale destacar que esse procedimento é um pouco subjetivo, sendo necessária a comparação com a imagem original para que a imagem processada represente as falhas superficiais e não manchas ou diferenças de tonalidade ao longo da superfície do concreto. A Figura 3.36 exemplifica as variações observadas com a utilização dos filtros.

Benito et al. (2015) destacam que o processamento e análise digital de imagens está intimamente ligado à qualidade da imagem usada. No trabalho apresentado pelos autores, foi utilizada uma câmera digital Canon de 10 Megapixels, posicionada perpendicularmente à

\footnotetext{
${ }^{9}$ IMAGEJ. An open platform for scientific image analysis. Disponível em $<$ https://imagej.net/Welcome $>$ acesso em: 07 de março de 2019.
} 
amostra e a 2 metros de distância desta. As fotografias foram tiradas sob luz ambiente indireta para que não houvesse interferências nas sombras dentro dos poros.

No presente trabalho, as fotografias foram tiradas com câmera digital Canon XS510 HS de 12.1 Megapixels. Foi posicionada luminária a cerca de 4 metros de distância das paredes pois a luz ambiente do interior do galpão do laboratório não era suficiente para iluminar adequadamente o ambiente. Os resultados foram processados seguindo o procedimento de correção de imagem apresentado anteriormente.

Figura 3.36 - Exemplos de diferenças no ajuste do balanço de cores que afetam os resultados.
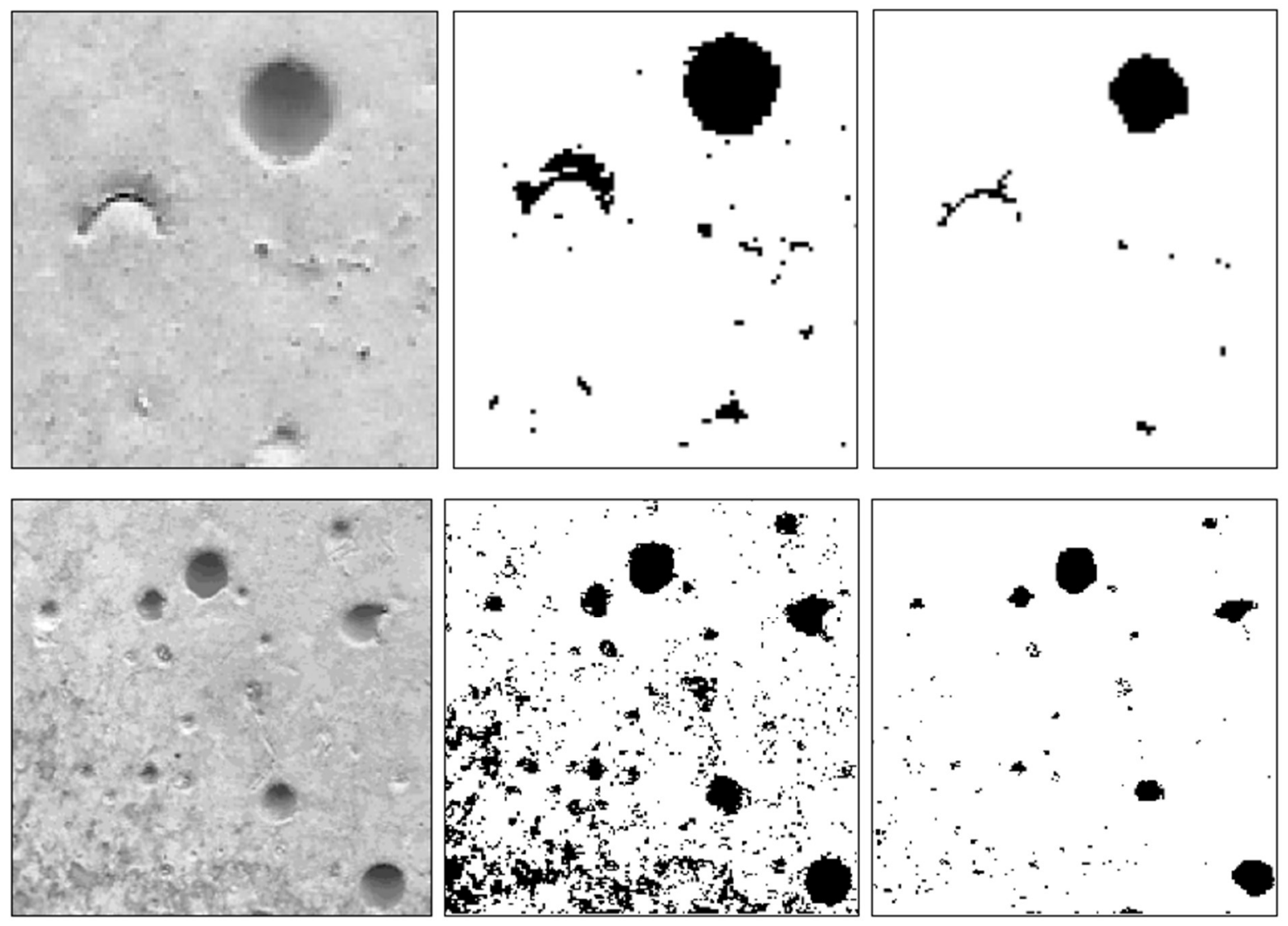

Fonte: Benito et al. (2015).

Uma peculiaridade do tratamento das imagens consistiu na correção de alguns vazios. Isso aconteceu porque, com o uso da luminária, a região interna de alguns defeitos superficiais ficou iluminada, de forma que a correção de cores excluía parte das falhas observadas. Utilizou-se, então, uma ferramenta do software que permite a exclusão de determinadas áreas por meio de seleção manual. Assim, os defeitos aparentes em cores claras foram marcados manualmente. 
Para a análise das paredes, foram consideradas regiões com $0,45 \mathrm{~m} \times 0,45 \mathrm{~m}$ nos oito quadrantes de cada parede, sendo 4 em cada face principal. Cada um desses quadrantes foi fotografado com uma trena posicionada ao lado, de maneira que fosse possível separar as regiões sem maiores dificuldades no software de processamento. Essa seleção é feita ao correlacionar uma distância conhecida na imagem com o número de pixels que ela possui, procedimento realizado com ferramenta no mesmo software.

Neste trabalho, o acabamento superficial foi relacionado apenas com a porcentagem de falhas superficiais (representadas pela cor preta) em relação à área total da amostra analisada. O software ImageJ possui uma função que indica essa porcentagem. Dessa forma, quanto maior for a região total em preto na imagem, pior será o acabamento superficial. Porém, o valor da área com defeitos em si não é suficiente para se estabelecer uma base de comparação com outros métodos de avaliação.

Assim, se propõe aqui uma correlação da falha superficial com outro método utilizado para avaliação do acabamento superficial de concretos: o relatório apresentado pela International Council for Research and Innovation in Building and Construction (CIB W29, 1973) que, como afirmam Almeida e Carretero (2016), é uma das primeiras classificações utilizadas para esta finalidade. Nesse relatório, são apresentadas sete diferentes classes de acabamento por meio de imagens e, a partir delas, a superfície de determinado concreto pode receber uma nota que vai de 1 até 7 , sendo 1 referente ao melhor acabamento, e 7, ao pior.

Apesar de ser um relatório antigo, ele ainda é utilizado como critério de avaliação nos dias atuais. Exemplo recente disso se deu por parte do Instituto Brasileiro do Concreto (IBRACON) que utilizou o relatório como critério de classificação pelo nível de incidência de bolhas superficiais em corpos de prova apresentados no concurso "QUEM SABE, FAZ AO VIVO" realizado durante o $60^{\circ}$ Congresso Brasileiro do Concreto ${ }^{10}$, em setembro de 2018.

Na sequência (Figura 3.37) estão apresentadas as 7 imagens definidas no CIB W29 (1973), seguidas das imagens processadas com o software ImageJ seguindo o procedimento de tratamento de imagens apresentado anteriormente.

\footnotetext{
${ }^{10}$ IBRACON. Regulamento do $2^{\circ}$ Concurso. Concreto: QUEM SABE, FAZ AO VIVO. 2018. Disponível em $<$ http://www.ibracon.org.br/eventos/60cbc/Regulamento_QuemSabeVivo2018.pdf > acesso em: 08 de março de 2019.
} 
Figura 3.37 - Acima, imagens dos acabamentos superficiais de concretos e respectivas notas conforme apresentado no CIB W29 1973, e abaixo imagens processadas com ImageJ.
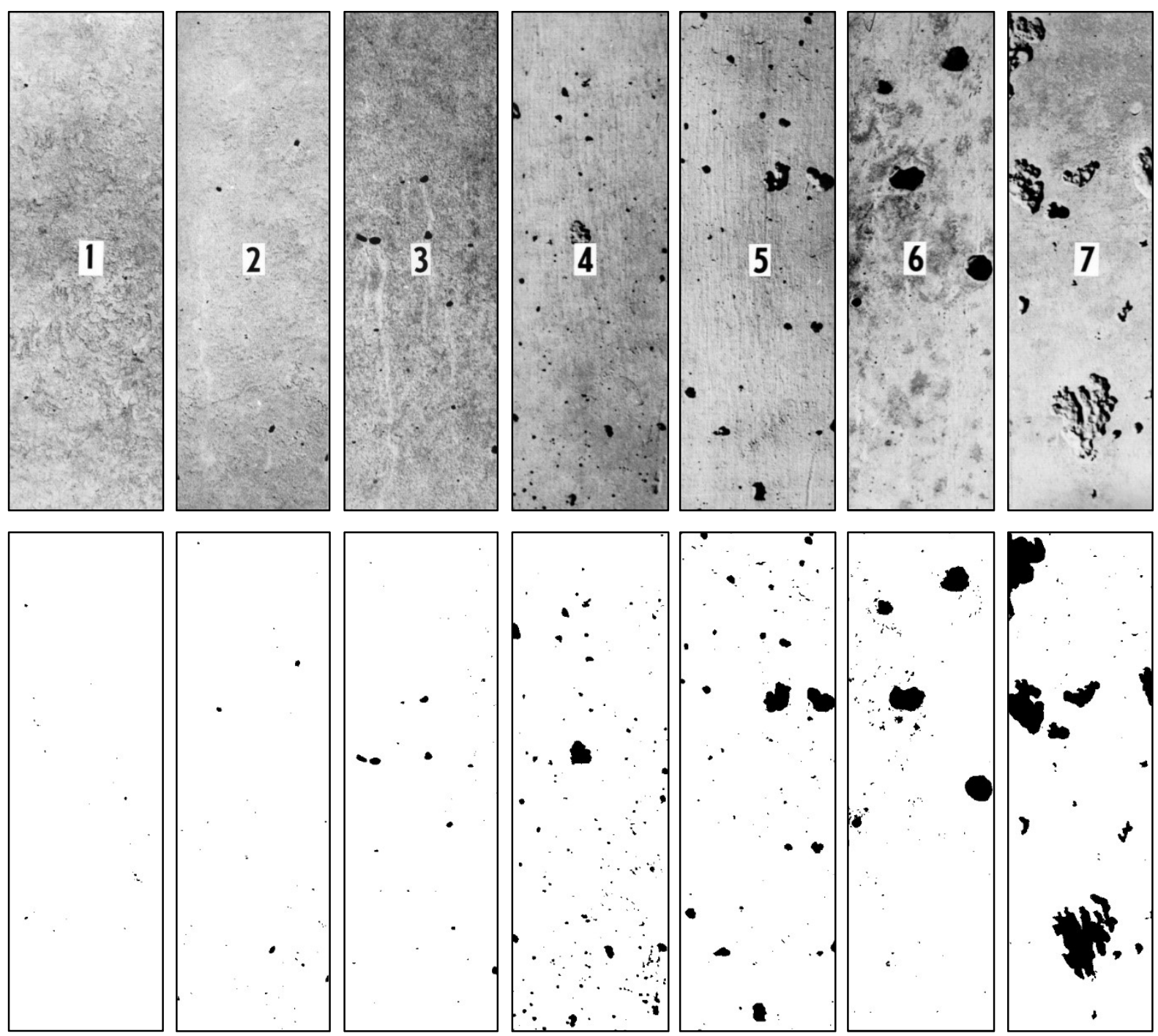

Fonte: Adaptado de CIB W29 (1973).

Com as imagens processadas, foi possível determinar qual a porcentagem de falha superficial referente a cada nota proposta no CIB W29 (1973), conforme apresentado na Tabela 3.13 .

Tabela 3.13 - Correlação entre nota de acabamento e região de falha superficial.

\begin{tabular}{cccccccc}
\hline Nota CIB W29 (1973) & 1 & 2 & 3 & 4 & 5 & 6 & 7 \\
\hline Região de falha superficial (\%) & 0,058 & 0,199 & 0,450 & 2,410 & 2,975 & 3,457 & 9,895 \\
\hline
\end{tabular}

A partir dessas correlações, montou-se um gráfico com interpolações lineares entre as notas, de maneira que, a partir da porcentagem de falha superficial obtida com o software ImageJ, é possível determinar a nota de acabamento com as equações definidas (Figura 3.38). 
Figura 3.38 - Correlação entre nota de acabamento e região de falha superficial.

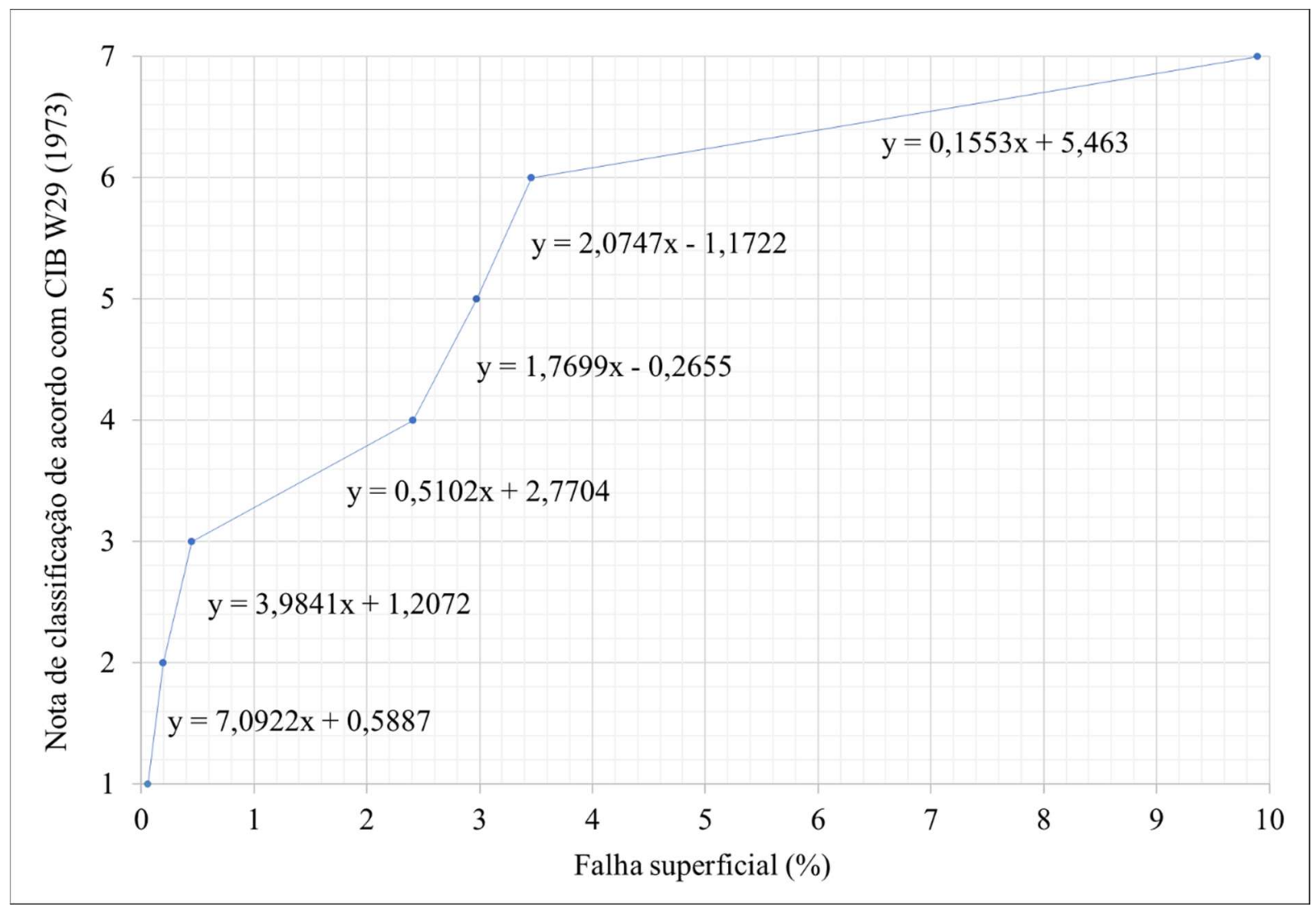

Deve-se ressaltar aqui que a escala utilizada como base apresenta valores inferior e superior de 1 e 7 , respectivamente. Portanto, o valor de y deve ser considerado dentro desse intervalo.

Feita a correlação entre as notas do CIB W29 (1973) e as imagens processadas pelo software ImageJ, pode-se então definir notas para o acabamento superficial das paredes concretadas.

\subsection{Avaliação da estrutura interna das paredes com ultrassom}

A última etapa deste trabalho consiste na análise da estrutura interna dos painéis de paredes concretadas. Foram separadas duas seções de cada parede: uma superior $(25 \mathrm{~cm}$ abaixo do topo) e uma inferior ( $25 \mathrm{~cm}$ acima da base).

A consideração dessas duas seções permite fazer uma análise comparativa da estrutura interna da parede em regiões que sofrem efeitos diferentes de adensamento. No caso da região inferior, a janela posicionada no centro da parede se apresenta como um obstáculo a 
ser contornado, criando cantos vivos que dificultam o adequado preenchimento. Por outro lado, a região superior não possui obstáculos para o lançamento do concreto.

O método de avaliação usa o equipamento de ultrassom Pundit Lab apresentado anteriormente no item 3.3.4 do presente trabalho. Para o ensaio, as seções inferior e superior de cada parede foram divididas horizontalmente em trechos de $5 \mathrm{~cm}$. O perímetro total da parede é de $320 \mathrm{~cm}$, resultando em 64 divisões. Cada um desses trechos foi identificado como um quadrado de $5 \mathrm{~cm}$ x $5 \mathrm{~cm}$, no qual seria posicionado o receptor/transmissor do aparelho de ultrassom. O esquema das seções ensaiadas é apresentado na Figura 3.39.

Figura 3.39 - Definição da malha para medição nos modelos de parede concretados.

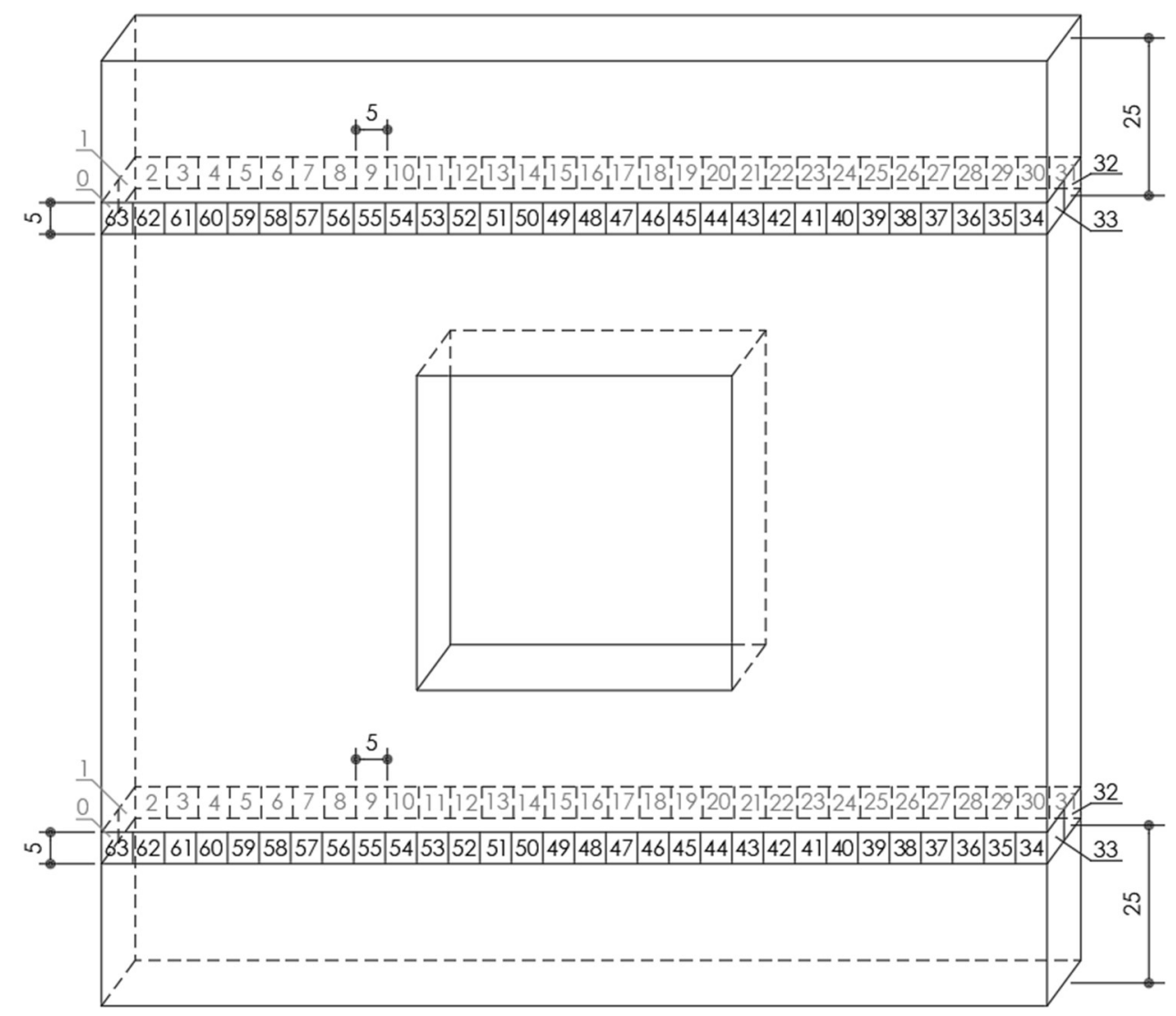

Fonte: Elaborado pelo autor.

Ao se fazer um corte na seção de ensaio, pode-se interpretar as regiões demarcadas como uma malha de 60 quadrados. A utilização do aparelho de ultrassom consiste em posicionar o receptor e o transmissor em todas as combinações possíveis sem haver repetição de medida, o que totaliza 1144 posições de medida. As Figuras 3.40 a 3.42 apresentam essas combinações. 
Figura 3.40 - 124 combinações de medida, com o transmissor posicionado nos pontos 0 e 1 e o receptor entre os pontos 2 e 63.

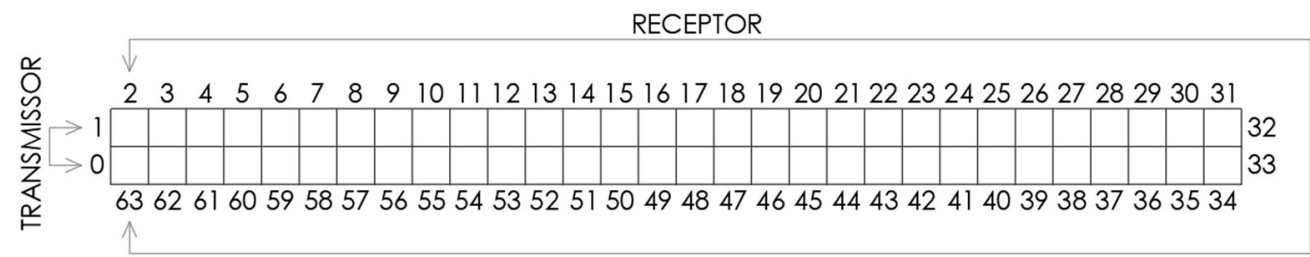

Fonte: Elaborado pelo autor.

Figura 3.41 - 960 combinações de medida, com o transmissor posicionado entre os pontos 2 e 31 e o receptor entre os pontos 32 e 63.

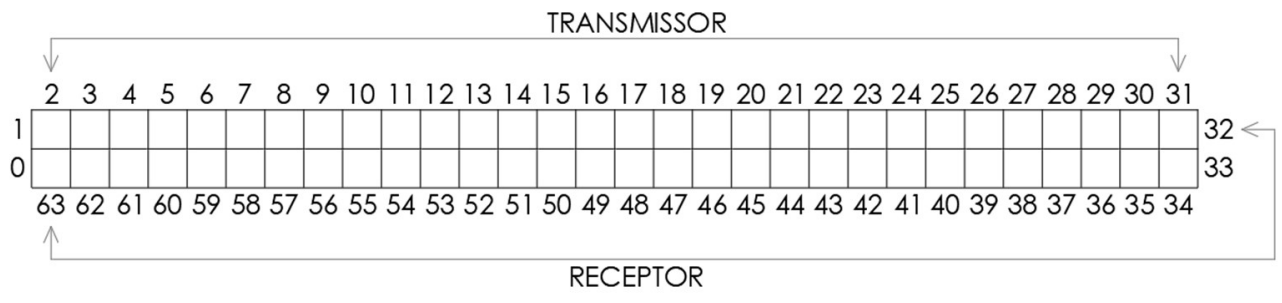

Fonte: Elaborado pelo autor.

Figura 3.42 - 60 combinações de medida, com o transmissor posicionado nos pontos 32 e 33 e o receptor entre os pontos 34 e 63.

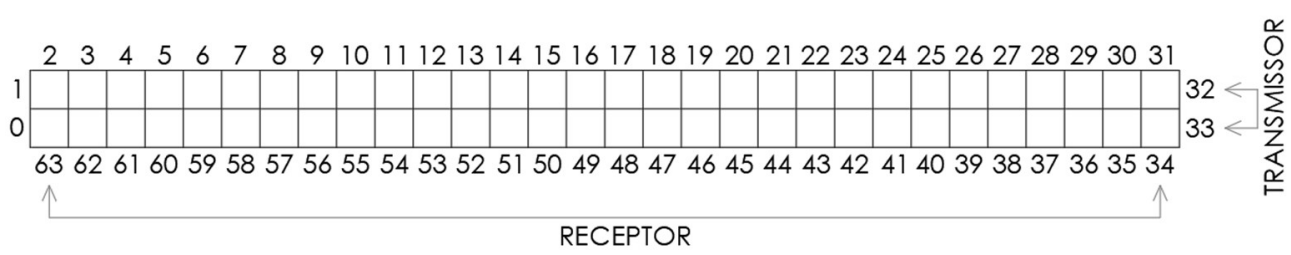

Fonte: Elaborado pelo autor.

Para cada posição são feitas 5 medições do tempo de transmissão do pulso ultrassônico pelo concreto. A malha apresentada nas Figuras 3.40 a 3.42 deve ser reproduzida no software de análise, considerando a numeração dos elementos conforme a ordem de posicionamento marcada nas paredes. Foi utilizado o software TUSom, desenvolvido no Departamento de Engenharia de Estruturas da EESC/USP, pelo Prof. Dr. Vladimir Guilherme Haach. As medições com dados de tempo e posições do transmissor e do receptor são então inseridas no software.

Com a malha previamente definida, o software determina as distâncias entre transmissor e receptor para cada uma das 1144 combinações possíveis e, com associação desses 
valores aos tempos de transmissão das ondas, determina qual a velocidade do pulso ultrassônico em cada um dos 1144 caminhos em linha reta gerados.

Essas linhas interceptam diferentes elementos da malha criada. Por exemplo, quando o transmissor está posicionado no ponto 1 e o receptor no ponto 32 , a linha reta considerada como a de transmissão das ondas sonoras intercepta 30 elementos diferentes. A velocidade em cada um dos 60 elementos da malha gerada não necessariamente será igual. $\mathrm{O}$ software, ao analisar todas as diferentes combinações, consegue apresentar de forma gráfica as diferentes velocidades observadas na seção.

Quanto maior for a variação de velocidades ao longo de toda a malha, menor será a homogeneidade da seção analisada e, consequentemente, maior será a quantidade de defeitos na estrutura interna da parede. Isso acontece porque, como pode ser visto em Saint-Pierre et al. (2016), uma maior porosidade e maior densidade de fissuras resultam na redução da velocidade do pulso ultrassônico. Dessa forma, ao se comparar as velocidades nas malhas inferior e superior de uma mesma parede, pode-se observar os efeitos práticos das diferenças no preenchimento do concreto das duas seções. 


\section{RESULTADOS E DISCUSSÃO}

Os resultados obtidos de acordo com a metodologia proposta estão apresentados em tópicos para facilitar a interpretação.

\subsection{Dosagem do concreto autoadensável}

Os materiais constituintes dos traços de concreto escolhidos para o desenvolvimento deste trabalho estão apresentados no item 3.1.1. Suas propriedades e características estão indicadas no Apêndice A.

Deve-se então ser feita a otimização da pasta. Dessa forma, é necessário, inicialmente, escolher a relação água/cimento a ser utilizada em cada traço. Com base em Ghazi e Al Jadiri (2010), definiu-se que para os concretos de classe C25 seria utilizada relação a/c de 0,55 , enquanto que para os de classe C40 seria de 0,45 .

Outra definição importante é que, para os concretos de classe C40, optou-se pela utilização de sílica em adição ao cimento. Seguindo o indicado por Gomes e Barros (2009), foi considerada relação sílica/cimento de 0,10. Essa escolha foi feita para aumentar as chances de os traços modificados com aditivo incorporador de ar apresentarem resistência suficiente para sua classificação como concreto estrutural.

Para o ensaio, foram consideradas pastas com seis diferentes proporções de fíler em relação ao cimento: $0 \%, 10 \%, 20 \%, 30 \%, 40 \%$ e $50 \%$. Optou-se por limitar a quantidade de f/c em 0,50 para que a mistura não ficasse muito pobre. Essas proporções foram adotadas para as duas classes de resistência propostas.

Em relação ao aditivo superplastificante, os valores considerados de $\mathrm{sp} / \mathrm{c}$ para o ensaio foram de $0,2 \%, 0,4 \%, 0,6 \%, 0,8 \%$ e $1,0 \%$ no caso da classe $\mathrm{C} 25$, e $0,4 \%, 0,6 \%, 0,8 \%$, $1,0 \%$ e $1,2 \%$ para classe $\mathrm{C} 40$. O intervalo recomendado pelo fabricante para a relação $\mathrm{sp} / \mathrm{c}$, considerando o aditivo utilizado, é de $0,4 \%$ até $1,0 \%{ }^{11}$. Optou-se por testar também uma dosagem menor no caso da classe C25 por ser uma mistura com maior quantidade de água.

Definidos esses parâmetros, foi iniciado o processo de otimização da pasta seguindo a metodologia proposta. Os ensaios com o cone de Marsh foram realizados no Laboratório de Materiais e Componentes da Construção Civil da Universidade Federal de São Carlos. Cada amostra utilizada apresentava massa total de $2000 \mathrm{~g}$.

\footnotetext{
${ }^{11}$ GCPAT. ADVA. Aditivo superplastificante (SP II) para concreto. Disponível em <https://gcpat.com.br/pt-
} br/solutions/products/adva-high-range-water-reducers/adva > acesso em: 18 de março de 2019. 
Figura 4.1 - Ponto de saturação do superplastificante para classe C25.
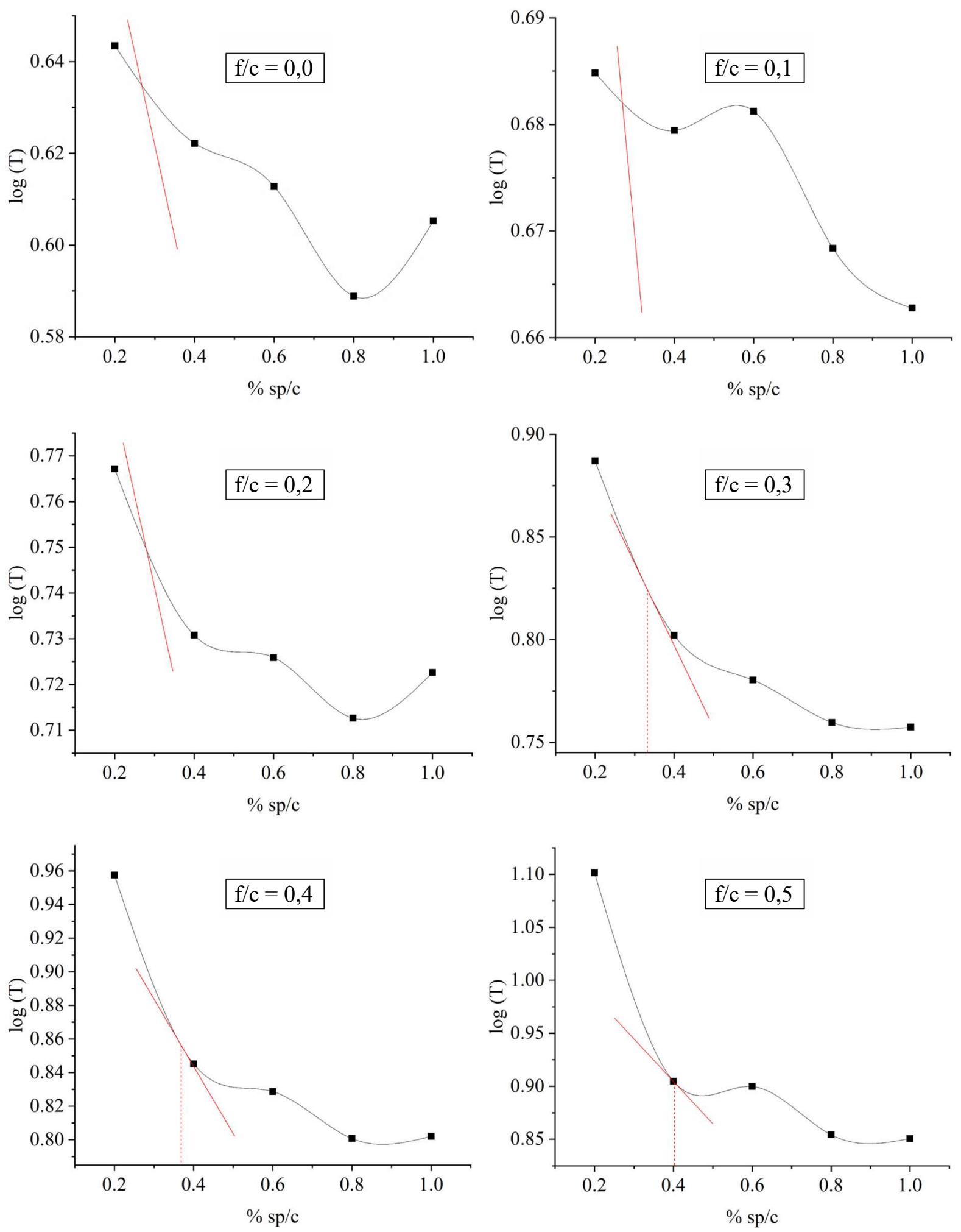

Fonte: Elaborada pelo autor.

Nas Figuras 4.1 e 4.2 estão apresentados os gráficos que correlacionam o teor de superplastificante com o logaritmo do tempo de escoamento para as diferentes proporções de 
fíler/cimento consideradas nas duas classes de concreto propostas, a fim de determinar o teor ótimo de aditivo superplastificante para cada composição utilizando o método AFREM.

Figura 4.2 - Ponto de saturação do superplastificante para classe C40.
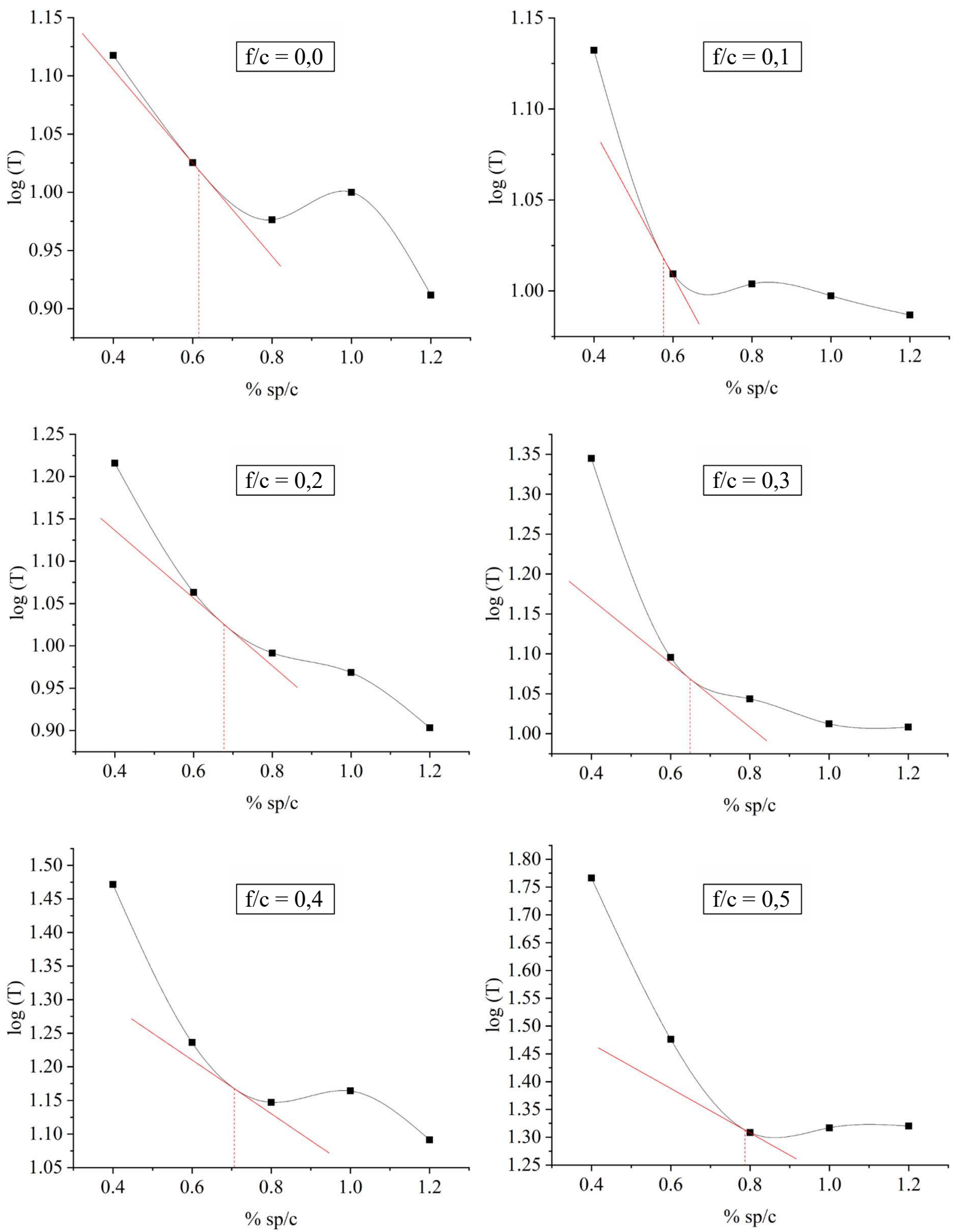

Fonte: Elaborada pelo autor. 
O tempo de escoamento de cada pasta de classe $\mathrm{C} 25$ com $0 \%, 10 \%$ e $20 \%$ de $\mathrm{f} / \mathrm{c}$ era muito curto e difícil de se medir com precisão. Dessa maneira, os resultados obtidos ficaram imprecisos, não sendo possível obter o teor ótimo de superplastificante a partir do método AFREM, proposto por DE LARRARD et al. (1997). Como solução, adotou-se um valor de sp/c igual a $0,20 \%$ para os referidos teores de fíler. Nas outras pastas, não houve problemas na determinação. Sendo assim, os teores ótimos de superplastificante para cada pasta foram definidos conforme Tabela 4.1.

Tabela 4.1 - Teor ótimo de superplastificante.

\begin{tabular}{ccccccccccccc}
\hline Relação & \multicolumn{1}{c}{ Classe C25 } & \multicolumn{1}{c}{ Classe C40 } \\
\hline $\mathrm{f} / \mathrm{c}$ & 0,00 & 0,10 & 0,20 & 0,30 & 0,40 & 0,50 & 0,00 & 0,10 & 0,20 & 0,30 & 0,40 & 0,50 \\
$\mathrm{sp} / \mathrm{c}(\%)$ & 0,20 & 0,20 & 0,20 & 0,33 & 0,37 & 0,40 & 0,62 & 0,58 & 0,68 & 0,65 & 0,71 & 0,79 \\
\hline
\end{tabular}

Fonte: Elaborada pelo autor.

Após a definição dos teores ótimos do aditivo, foi realizado ensaio de miniabatimento. Esse ensaio também foi realizado nas instalações do Laboratório de Materiais e Componentes da Construção Civil da UFSCar. Para esse ensaio, foram utilizadas amostras de pasta com $1500 \mathrm{~g}$. Os resultados estão apresentados nas Tabelas 4.2 e 4.3.

Tabela 4.2 - Concreto classe C25 - Resultados para ensaio de miniabatimento.

\begin{tabular}{|c|c|c|c|c|c|c|c|c|c|c|}
\hline \multicolumn{4}{|c|}{ Relações } & \multicolumn{5}{|c|}{ Massa (g) } & \multirow{2}{*}{$\begin{array}{l}\text { Tempo (s) } \\
{[115 \text { mm] }}\end{array}$} & \multirow{2}{*}{$\begin{array}{l}\text { Espalhamento } \\
\text { médio (mm) }\end{array}$} \\
\hline $\mathbf{a} / \mathbf{c}$ & $\mathbf{f} / \mathbf{c}$ & $\mathbf{s p} / \mathbf{c}$ & $\mathbf{s} / \mathbf{c}$ & c & $\mathbf{a}$ & f & sp & s & & \\
\hline 0,55 & 0 & 0,0020 & 0,0 & 966,5 & 531,6 & 0,0 & 1,93 & 0,0 & 0,22 & 217,5 \\
\hline 0,55 & 0,1 & 0,0020 & 0,0 & 908,0 & 499,4 & 90,8 & 1,82 & 0,0 & 0,18 & 206,0 \\
\hline 0,55 & 0,2 & 0,0020 & 0,0 & 856,2 & 470,9 & 171,2 & 1,71 & 0,0 & 0,18 & 196,0 \\
\hline 0,55 & 0,3 & 0,0033 & 0,0 & 809,4 & 445,2 & 242,8 & 2,67 & 0,0 & 0,19 & 195,5 \\
\hline 0,55 & 0,4 & 0,0037 & 0,0 & 767,8 & 422,3 & 307,1 & 2,84 & 0,0 & 0,19 & 193,0 \\
\hline 0,55 & 0,5 & 0,0040 & 0,0 & 730,3 & 401,7 & 365,1 & 2,92 & 0,0 & 0,19 & 189,0 \\
\hline
\end{tabular}


Tabela 4.3 - Concreto classe C40 - Resultados para ensaio de miniabatimento.

\begin{tabular}{|c|c|c|c|c|c|c|c|c|c|c|}
\hline \multicolumn{4}{|c|}{ Relações } & \multicolumn{5}{|c|}{ Massa (g) } & \multirow{2}{*}{$\begin{array}{l}\text { Tempo (s) } \\
{[115 \mathrm{~mm}]}\end{array}$} & \multirow{2}{*}{$\begin{array}{l}\text { Espalhamento } \\
\text { médio }(\mathbf{m m})\end{array}$} \\
\hline $\mathbf{a} / \mathbf{c}$ & $\mathbf{f} / \mathbf{c}$ & $\mathrm{sp} / \mathrm{c}$ & $\mathbf{s} / \mathbf{c}$ & c & $\mathbf{a}$ & f & sp & $\mathbf{s}$ & & \\
\hline 0,45 & 0 & 0,0062 & 0,1 & 963,9 & 433,7 & 0,0 & 5,98 & 96,4 & 0,59 & 193,0 \\
\hline 0,45 & 0,1 & 0,0058 & 0,1 & 905,9 & 407,7 & 90,6 & 5,25 & 90,6 & 0,78 & 196,0 \\
\hline 0,45 & 0,2 & 0,0068 & 0,1 & 853,8 & 384,2 & 170,8 & 5,81 & 85,4 & 0,72 & 197,0 \\
\hline 0,45 & 0,3 & 0,0065 & 0,1 & 808,0 & 363,6 & 242,4 & 5,25 & 80,8 & 0,85 & 183,5 \\
\hline 0,45 & 0,4 & 0,0071 & 0,1 & 766,4 & 344,9 & 306,6 & 5,44 & 76,6 & 1,13 & 197,5 \\
\hline 0,45 & 0,5 & 0,0079 & 0,1 & 728,9 & 328,0 & 364,4 & 5,76 & 72,9 & 1,53 & 182,5 \\
\hline
\end{tabular}

Fonte: Elaborada pelo autor.

Segundo Gomes, Gettu e Agulló (2003), a relação f/c adequada é obtida quando a pasta alcançar a marca de $115 \mathrm{~mm}$ de diâmetro em um intervalo de tempo de $2 \mathrm{~s}$ a $4 \mathrm{~s}$ e quando o diâmetro final for de $(180 \pm 10) \mathrm{mm}$. Como pode ser observado, os tempos obtidos para a marca de 115 mm são muito baixos (podendo inclusive apresentar falhas de medição nas pastas mais fluidas), não chegando a atingir $2 \mathrm{~s}$ em nenhuma das pastas analisadas. Assim, a escolha das pastas foi feita considerando apenas o espalhamento médio.

Considerando os limites apresentados, foram escolhidas as pastas com relação f/c igual a 0,5 , tanto para a classe $\mathrm{C} 25$, quanto para a classe $\mathrm{C} 40$. Consequentemente, os valores da relação sp/c definidos para as classes C25 e C40 foram de 0,40\% e 0,79\%, respectivamente.

Vale ressaltar que, de acordo com o critério considerado, a pasta com relação f/c de 0,3 para a classe C40 também seria adequada. Porém, foi escolhida a relação f/c de 0,5 pelo fato de o tempo obtido se aproximar mais do limite inferior de $2 \mathrm{~s}$ apresentado anteriormente.

A etapa seguinte do processo de dosagem consistiu na definição do esqueleto granular dos agregados. Nesta pesquisa, são utilizados dois tipos de areia com granulometrias diferentes (média e fina) e apenas um tipo de agregado graúdo (pedra britada com diâmetro máximo característico de 9,5 mm). Assim, a determinação do esqueleto granular deve ser feita em duas etapas: primeiro entre as areias e, na sequência, entre a brita e as areias com as proporções já definidas.

No caso dos agregados miúdos, Leite (2018) fez os estudos para as areias utilizadas no presente trabalho. Portanto, a proporção ideal entre areia média e areia fina adotada foi a mesma do referido trabalho, em que a relação ótima encontrada fixou uma proporção de $40 \%$ de areia fina e $60 \%$ de areia média. 
A partir da proporção entre areias definida, foi feito o estudo de composição com a brita. Na Figura 4.3 está apresentado o gráfico para a determinação do esqueleto granular dos agregados. Vale destacar que a porcentagem de areia apresentada corresponde à proporção citada entre areia fina e areia média.

Figura 4.3 - Definição do esqueleto granular para os agregados utilizados.

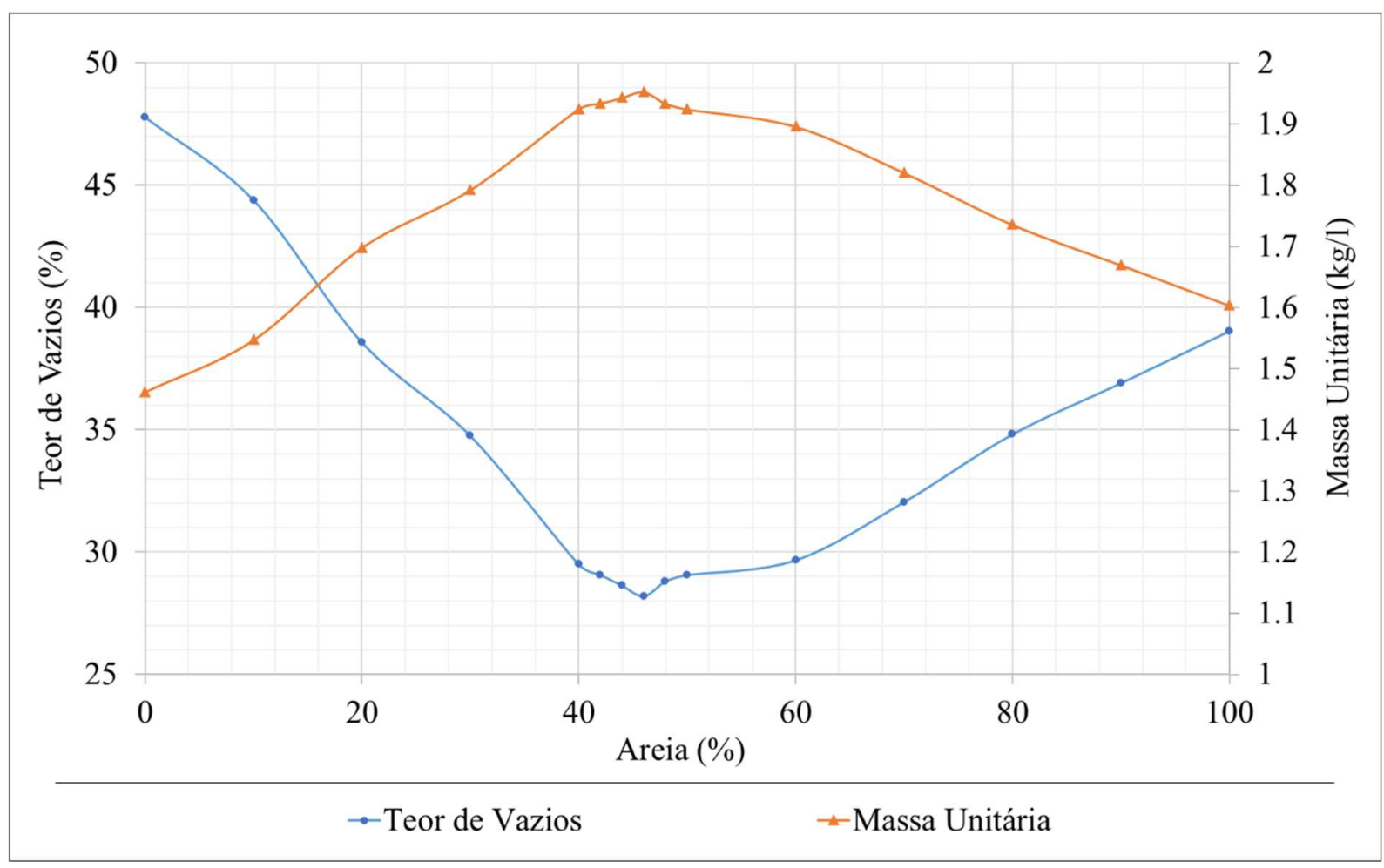

Fonte: Elaborada pelo autor.

O gráfico obtido define $46 \%$ de agregado miúdo (AM) e 54\% de agregado graúdo (AG), sendo AM composto por areias média e fina $(60 \%$ e $40 \%$, respectivamente) e AG composto unicamente pela pedra britada.

Após as otimizações da pasta e do esqueleto granular, foram feitos testes para o concreto no estado fresco variando a quantidade de pasta, de forma a se definir o volume de pasta ideal para a mistura de concreto. A realização dos testes considerou 4 diferentes volumes de pasta, baseados em valores apresentados por Gomes (2002): 36\%, 38\%, 40\% e 42\%. Os resultados de caracterização em estado fresco obtidos para as duas classes de concreto estão apresentados nas Tabelas 4.4 e 4.5 . 
Tabela 4.4 - Concreto classe C25 - Definição do volume de pasta para o CAA.

\begin{tabular}{|c|c|c|c|c|c|c|}
\hline \multirow{2}{*}{\multicolumn{2}{|c|}{ Parâmetros }} & \multirow{2}{*}{$\begin{array}{c}\text { Limites } \\
\text { Considerados }\end{array}$} & \multicolumn{4}{|c|}{ Volume de Pasta (\%) } \\
\hline & & & 36 & 38 & 40 & 42 \\
\hline \multirow{3}{*}{$\begin{array}{l}\text { Slump } \\
\text { flow }\end{array}$} & Medida $1(\mathrm{~mm})$ & - & 430 & 650 & 780 & 800 \\
\hline & Medida $2(\mathrm{~mm})$ & - & 420 & 600 & 770 & 810 \\
\hline & Média (mm) & 760 a $850 \mathrm{~mm}$ & 425 & 625 & 775 & 805 \\
\hline $\mathbf{T}_{500}(\mathrm{~s})$ & & $\leq 2 \mathrm{~s}$ & - & 1,78 & 1,63 & 0,88 \\
\hline IEV & & Estável & Estável & Estável & Estável & Instável \\
\hline \multirow{4}{*}{ Anel J } & Medida $1(\mathrm{~mm})$ & - & 370 & 570 & 670 & 790 \\
\hline & Medida $2(\mathrm{~mm})$ & - & 360 & 580 & 680 & 780 \\
\hline & Média (mm) & - & 365 & 575 & 675 & 785 \\
\hline & Slump flow - Anel J & 0 a $25 \mathrm{~mm}$ & 60 & 50 & 100 & 20 \\
\hline \multirow{3}{*}{ Caixa $\mathbf{L}$} & $\mathrm{H} 1$ & - & 16 & 10 & 10 & 9 \\
\hline & $\mathrm{H} 2$ & - & 0 & 7.0 & 8,5 & 8,5 \\
\hline & $\mathrm{H} 2$ / H1 & $\geq 0,80$ & 0 & 0,70 & 0,85 & 0,94 \\
\hline Funil V (s) & & $<9 \mathrm{~s}$ & 5,56 & 3,63 & 3,01 & 2,42 \\
\hline \multirow{3}{*}{$\begin{array}{l}\text { Coluna de } \\
\text { Segregação }\end{array}$} & Massa topo $(\mathrm{kg})$ & - & 4,5 & 4,75 & 4,15 & 4,2 \\
\hline & Massa base (kg) & - & 4,6 & 4,8 & 4,25 & 4,7 \\
\hline & $\begin{array}{c}\text { Massa topo / Massa } \\
\text { base }(\%)\end{array}$ & $\leq 15 \%$ & 2,17 & 1,04 & 2,35 & 10,64 \\
\hline
\end{tabular}

Fonte: Elaborada pelo autor.

Tabela 4.5 - Concreto classe C40 - Definição do volume de pasta para o CAA.

\begin{tabular}{|c|c|c|c|c|c|c|}
\hline \multirow{2}{*}{\multicolumn{2}{|c|}{ Parâmetros }} & \multirow{2}{*}{$\begin{array}{c}\text { Limites } \\
\text { Considerados }\end{array}$} & \multicolumn{4}{|c|}{ Volume de Pasta (\%) } \\
\hline & & & 36 & 38 & 40 & 42 \\
\hline \multirow{3}{*}{$\begin{array}{l}\text { Slump } \\
\text { flow }\end{array}$} & Medida $1(\mathrm{~mm})$ & - & 720 & 760 & 840 & 830 \\
\hline & Medida $2(\mathrm{~mm})$ & - & 750 & 760 & 810 & 860 \\
\hline & Média (mm) & 760 a $850 \mathrm{~mm}$ & 735 & 760 & 825 & 845 \\
\hline $\mathbf{T}_{500}(\mathrm{~s})$ & & $\leq 2 \mathrm{~s}$ & 1,85 & 1,37 & 1,2 & 1,09 \\
\hline IEV & & Estável & Estável & Estável & Instável & Instável \\
\hline \multirow{4}{*}{ Anel J } & Medida $1(\mathrm{~mm})$ & - & 610 & 760 & 830 & 830 \\
\hline & Medida $2(\mathrm{~mm})$ & - & 680 & 750 & 810 & 840 \\
\hline & Média (mm) & - & 645 & 755 & 820 & 835 \\
\hline & Slump flow - Anel J & 0 a $25 \mathrm{~mm}$ & 90 & 5 & 5 & 10 \\
\hline \multirow{3}{*}{ Caixa L } & $\mathrm{H} 1$ & - & 9,5 & 9 & 8,5 & 8,5 \\
\hline & $\mathrm{H} 2$ & - & 7,5 & 8,5 & 8,5 & 8,5 \\
\hline & $\mathrm{H} 2$ / H1 & $\geq 0,80$ & 0,79 & 0,94 & 1 & 1 \\
\hline Funil V (s) & & $<9 \mathrm{~s}$ & 6,3 & 6 & 4,4 & 3,45 \\
\hline \multirow{3}{*}{$\begin{array}{l}\text { Coluna de } \\
\text { Segregação }\end{array}$} & Massa topo (kg) & - & 4,8 & 4,35 & 3,95 & 3,85 \\
\hline & Massa base (kg) & - & 5,05 & 4,8 & 4,6 & 4,5 \\
\hline & $\begin{array}{c}\text { Massa topo / Massa } \\
\text { base }(\%)\end{array}$ & $\leq 15 \%$ & 4,95 & 9,38 & 14,13 & 14,44 \\
\hline
\end{tabular}

Fonte: Elaborada pelo autor. 
As Figuras 4.4 e 4.5 mostram um compilado de fotos do espalhamento para os volumes de pasta testados em cada classe de resistência.

Figura 4.4 - Concreto classe C25 - Compilado dos espalhamentos obtidos para os diferentes volumes de pasta considerados: $36 \%$ (a), $38 \%$ (b), $40 \%$ (c) e $42 \%$ (d).

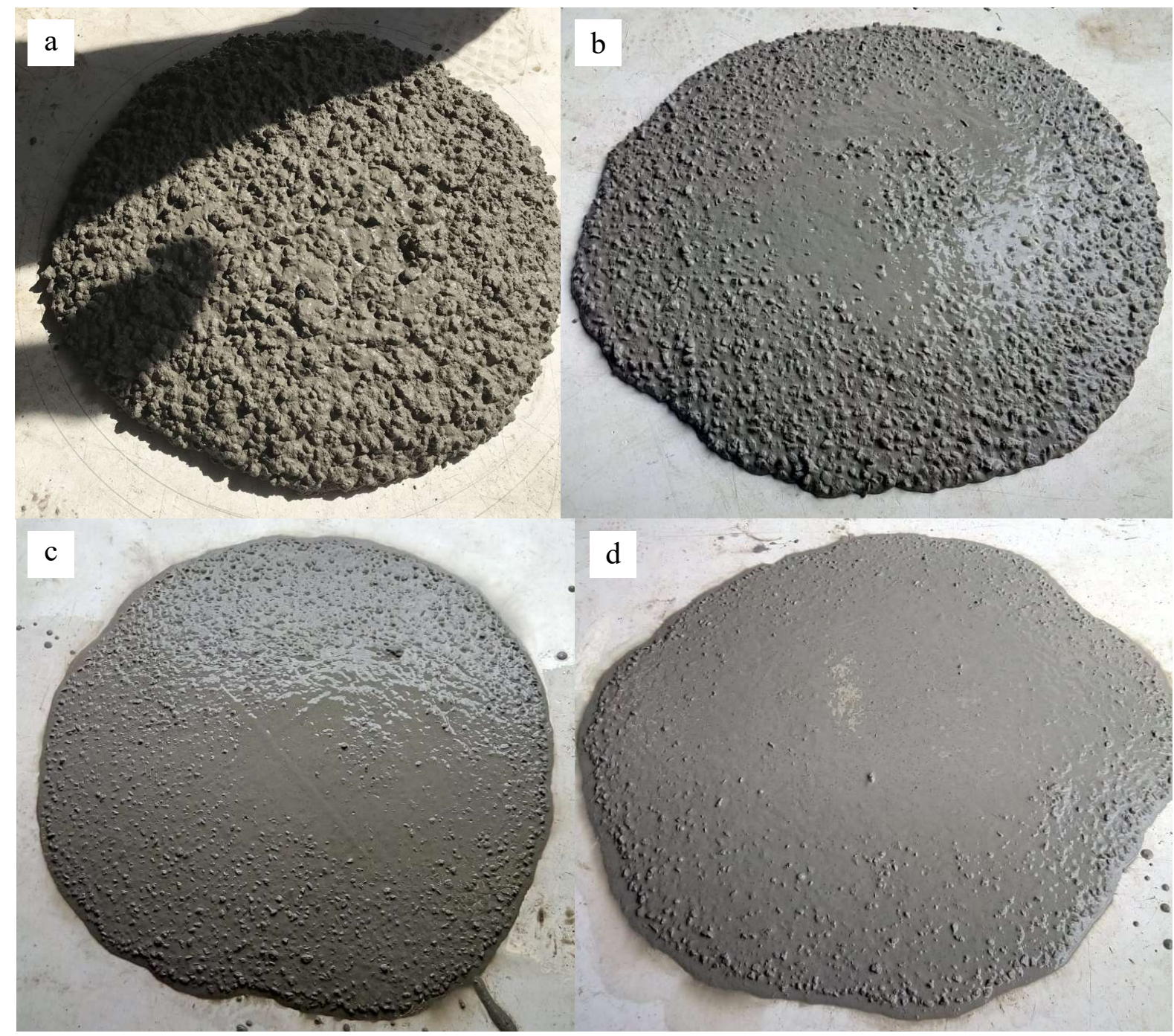

Fonte: Elaborada pelo autor.

Ao se comparar os resultados obtidos com os limites considerados, foi escolhido o volume de pasta de $40 \%$ para a classe C25, enquanto que para a classe C40 foi escolhido um volume de 38\%. Todos os limites impostos são respeitados para esses dois volumes de pasta, com exceção do anel J para a pasta de 40\% na classe C25. Nesse caso, o ensaio foi feito de maneira um pouco tardia em relação ao espalhamento, resultando em diferença acima do limite. 
Figura 4.5 - Concreto classe C40 - Compilado dos espalhamentos obtidos para os diferentes volumes de pasta considerados: $36 \%$ (a), $38 \%$ (b), $40 \%$ (c) e $42 \%$ (d).

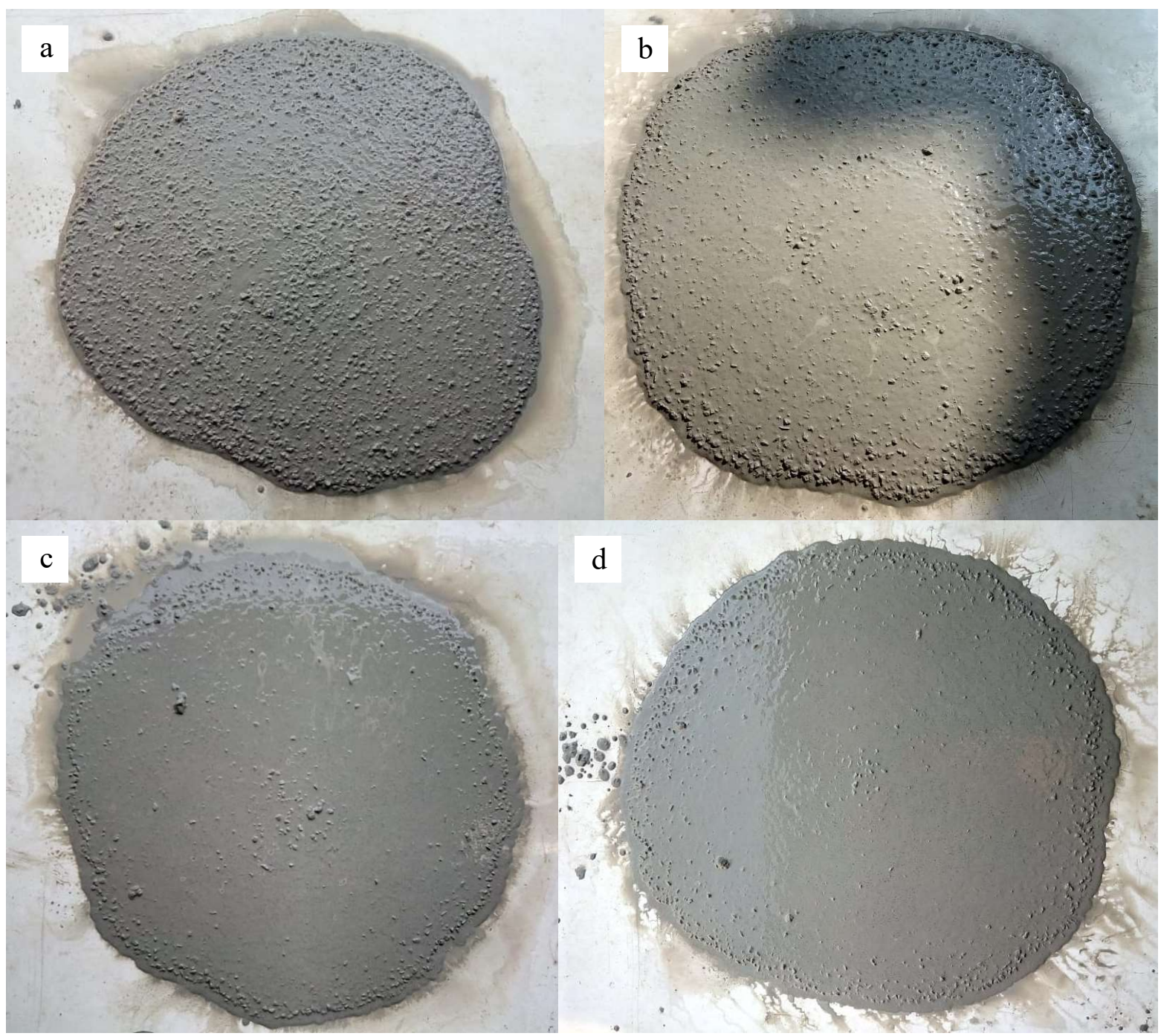

Fonte: Elaborada pelo autor.

A Tabela 4.6 apresenta os traços de referência definidos para cada classe de resistência a partir dos ensaios realizados.

É importante destacar que o consumo de água para produção foi corrigido em função da absorção por parte dos agregados, conforme estabelecido na metodologia de dosagem empregada no estudo. Dessa forma a quantidade de água adicionada à mistura foi um pouco maior do que a definida no traço considerando a relação água/cimento. O consumo de água para produção foi de $228 \mathrm{~kg} / \mathrm{m}^{3}$ e $187 \mathrm{~kg} / \mathrm{m}^{3}$ para as classes $\mathrm{C} 25$ e C40, respectivamente. 
Tabela 4.6 - Consumo de materiais para os traços definidos.

\begin{tabular}{ccc}
\hline \multicolumn{3}{c}{ Consumo de Materiais $\left(\mathbf{k g} / \mathbf{m}^{\mathbf{3}}\right)$} \\
\hline \multirow{2}{*}{ Materiais } & $\mathrm{C} 25$ & $\mathrm{Classe}$ \\
\cline { 2 - 3 } & 380 & 377 \\
\hline Cimento & 0 & 38 \\
\hline Sílica ativa & 190 & 188 \\
\hline Fíler calcário & 209 & 170 \\
\hline Água & 1,519 & 2,976 \\
Superplastificante & 307 & 318 \\
\hline Areia fina & 461 & 476 \\
\hline Areia média & 902 & 932 \\
\hline Brita & Fonte: Elaborada pelo autor.
\end{tabular}

\subsection{Caracterização dos concretos de referência}

A sequência do trabalho se deu com a verificação das propriedades em estado endurecido para os traços definidos e ainda com uma reavaliação das propriedades em estado fresco quando da produção dos concretos para moldagem dos corpos de prova. Para efeitos de identificação, os traços aqui propostos paras as classes C25 e C40 serão denominados de "C25 referência" e "C40 referência".

O volume necessário para a concretagem de todos os corpos de prova e ainda para avaliação das propriedades em estado fresco exigia 120 litros de concreto, de maneira a compensar as possíveis perdas durante todo o processo. Para esse volume, foram consideradas 3 betonadas, com 40 litros de cada vez. Todos os parâmetros de autoadensabilidade, com exceção do anel J, eram obtidos na primeira betonada, enquanto que na segunda era novamente medido o espalhamento e na terceira feito o ensaio de anel $\mathrm{J}$.

\subsubsection{Propriedades do concreto em estado fresco para traços de referência}

As propriedades do concreto em estado fresco para os traços C25 e C40 de referência estão apresentadas nas Tabelas 4.7 e 4.8. Assim como nos ensaios de definição do volume de pasta, a caraterização em estado fresco para os traços de referência escolhidos mostra que os limites considerados são respeitados, sendo necessário apenas ressaltar que a primeira betonada do C40 de referência apresentou espalhamento menor pois a betoneira falhou durante a mistura, ficando parada por cerca de 10 minutos. 
Tabela 4.7 - C25 referência - Caracterização do concreto autoadensável em estado fresco.

\begin{tabular}{|c|c|c|c|c|c|}
\hline \multicolumn{2}{|c|}{ Parâmetros } & $\begin{array}{c}\text { Limites } \\
\text { Considerados }\end{array}$ & $\begin{array}{l}\text { Primeira } \\
\text { Betonada }\end{array}$ & $\begin{array}{c}\text { Segunda } \\
\text { Betonada }\end{array}$ & $\begin{array}{c}\text { Terceira } \\
\text { Betonada }\end{array}$ \\
\hline \multirow{3}{*}{$\begin{array}{l}\text { Slump } \\
\text { flow }\end{array}$} & Medida $1(\mathrm{~mm})$ & - & 760 & 770 & - \\
\hline & Medida $2(\mathrm{~mm})$ & - & 740 & 760 & - \\
\hline & Média (mm) & 760 a $850 \mathrm{~mm}$ & 750 & 765 & - \\
\hline \multicolumn{2}{|l|}{$\mathbf{T}_{500}(\mathrm{~s})$} & $\leq 2 \mathrm{~s}$ & 1,36 & - & - \\
\hline \multicolumn{2}{|l|}{ IEV } & Estável & Estável & Estável & Estável \\
\hline \multirow{4}{*}{ Anel J } & Medida $1(\mathrm{~mm})$ & - & - & - & 740 \\
\hline & Medida $2(\mathrm{~mm})$ & - & - & - & 730 \\
\hline & Média (mm) & - & - & - & 735 \\
\hline & Slump flow - Anel J & 0 a $25 \mathrm{~mm}$ & - & - & - \\
\hline \multirow{3}{*}{ Caixa $L$} & $\mathrm{H} 1$ & - & 9,5 & - & - \\
\hline & $\mathrm{H} 2$ & - & 8,5 & - & - \\
\hline & $\mathrm{H} 2 / \mathrm{H} 1$ & $\geq 0,80$ & 0,89 & - & - \\
\hline \multicolumn{2}{|l|}{ Funil V (s) } & $<9 \mathrm{~s}$ & 2,90 & - & - \\
\hline \multirow{3}{*}{$\begin{array}{l}\text { Coluna de } \\
\text { Segregação }\end{array}$} & Massa topo (kg) & - & 4,5 & - & - \\
\hline & Massa base (kg) & - & 4,55 & - & - \\
\hline & $\begin{array}{c}\text { Massa topo / Massa } \\
\text { base }(\%)\end{array}$ & $\leq 15 \%$ & 1,1 & - & - \\
\hline
\end{tabular}

Tabela 4.8 - C40 referência - Caracterização do concreto autoadensável em estado fresco.

\begin{tabular}{|c|c|c|c|c|c|}
\hline \multicolumn{2}{|c|}{ Parâmetros } & $\begin{array}{c}\text { Limites } \\
\text { Considerados }\end{array}$ & $\begin{array}{l}\text { Primeira } \\
\text { Betonada }\end{array}$ & $\begin{array}{c}\text { Segunda } \\
\text { Betonada }\end{array}$ & $\begin{array}{r}\text { Terceira } \\
\text { Betonada }\end{array}$ \\
\hline \multirow{3}{*}{$\begin{array}{l}\text { Slump } \\
\text { flow }\end{array}$} & Medida $1(\mathrm{~mm})$ & - & 670 & 760 & - \\
\hline & Medida $2(\mathrm{~mm})$ & - & 650 & 780 & - \\
\hline & Média (mm) & 760 a $850 \mathrm{~mm}$ & 660 & 770 & - \\
\hline $\mathbf{T}_{500}(\mathbf{s})$ & & $\leq 2 \mathrm{~s}$ & 1,66 & - & - \\
\hline IEV & & Estável & Estável & Estável & Estável \\
\hline \multirow{4}{*}{ Anel J } & Medida $1(\mathrm{~mm})$ & - & - & - & 750 \\
\hline & Medida $2(\mathrm{~mm})$ & - & - & - & 740 \\
\hline & Média (mm) & - & - & - & 745 \\
\hline & Slump flow - Anel J & 0 a $25 \mathrm{~mm}$ & - & - & - \\
\hline \multirow{3}{*}{ Caixa $L$} & $\mathrm{H} 1$ & - & 10 & - & - \\
\hline & $\mathrm{H} 2$ & - & 8,0 & - & - \\
\hline & $\mathrm{H} 2$ / H1 & $\geq 0,80$ & 0,80 & - & - \\
\hline Funil V (s) & & $<9 \mathrm{~s}$ & 5,41 & - & - \\
\hline \multirow{3}{*}{$\begin{array}{l}\text { Coluna de } \\
\text { Segregação }\end{array}$} & Massa topo $(\mathrm{kg})$ & - & 4,80 & - & - \\
\hline & Massa base (kg) & - & 4,90 & - & - \\
\hline & $\begin{array}{c}\text { Massa topo / Massa } \\
\text { base }(\%)\end{array}$ & $\leq 15 \%$ & 2,0 & - & - \\
\hline
\end{tabular}

Fonte: Elaborada pelo autor. 


\subsubsection{Propriedades do concreto em estado endurecido para traços de referência}

Em termos de ensaios para o estado endurecido, os resultados e análises das propriedades para os concretos C25 e C40 de referência estão apresentados na sequência.

- Concreto $\mathrm{C} 25$ de referência:

Tabela 4.9 - C25 referência - Resultados de resistência à compressão.

\begin{tabular}{cccccccc}
\hline \multicolumn{7}{c}{ Resistência à Compressão (MPa) } \\
\hline \multirow{2}{*}{ CP } & 12 horas & 15 horas & 18 horas & 21 horas & 24 horas & 7 dias & 28 dias \\
\cline { 2 - 8 } & 1,50 & 2,53 & 3,87 & 6,39 & 7,24 & 21,76 & 41,34 \\
\hline 1 & 1,56 & 2,71 & 4,13 & 6,17 & 7,76 & 25,88 & 43,64 \\
2 & 1,70 & 2,71 & 3,94 & 6,40 & 7,64 & 27,38 & 43,56 \\
3 & - & - & - & - & - & - & 44,56 \\
4 & - & - & - & - & - & - & $-*$ \\
5 & 1,59 & 2,65 & 3,98 & 6,32 & 7,55 & 25,01 & 43,28 \\
Média & 0,10 & 0,10 & 0,13 & 0,13 & 0,27 & 2,91 & 1,37 \\
Desvio Padrão & 6,37 & 3,89 & 3,37 & 2,06 & 3,59 & 11,60 & 3,20 \\
\hline CV (\%) & & & & & & &
\end{tabular}

Nota:

* O equipamento utilizado para a compressão dos corpos de prova falhou durante o ensaio do quinto corpo de prova aos 28 dias.

Fonte: Elaborada pelo autor.

A Figura 4.6 apresenta a evolução da resistência à compressão, sendo que as idades estão representadas em horas. Portanto, 7 dias é referente a 168 horas e 28 dias, 672 horas.

Figura 4.6 - C25 referência - Evolução da resistência à compressão (valores médios) com o tempo.

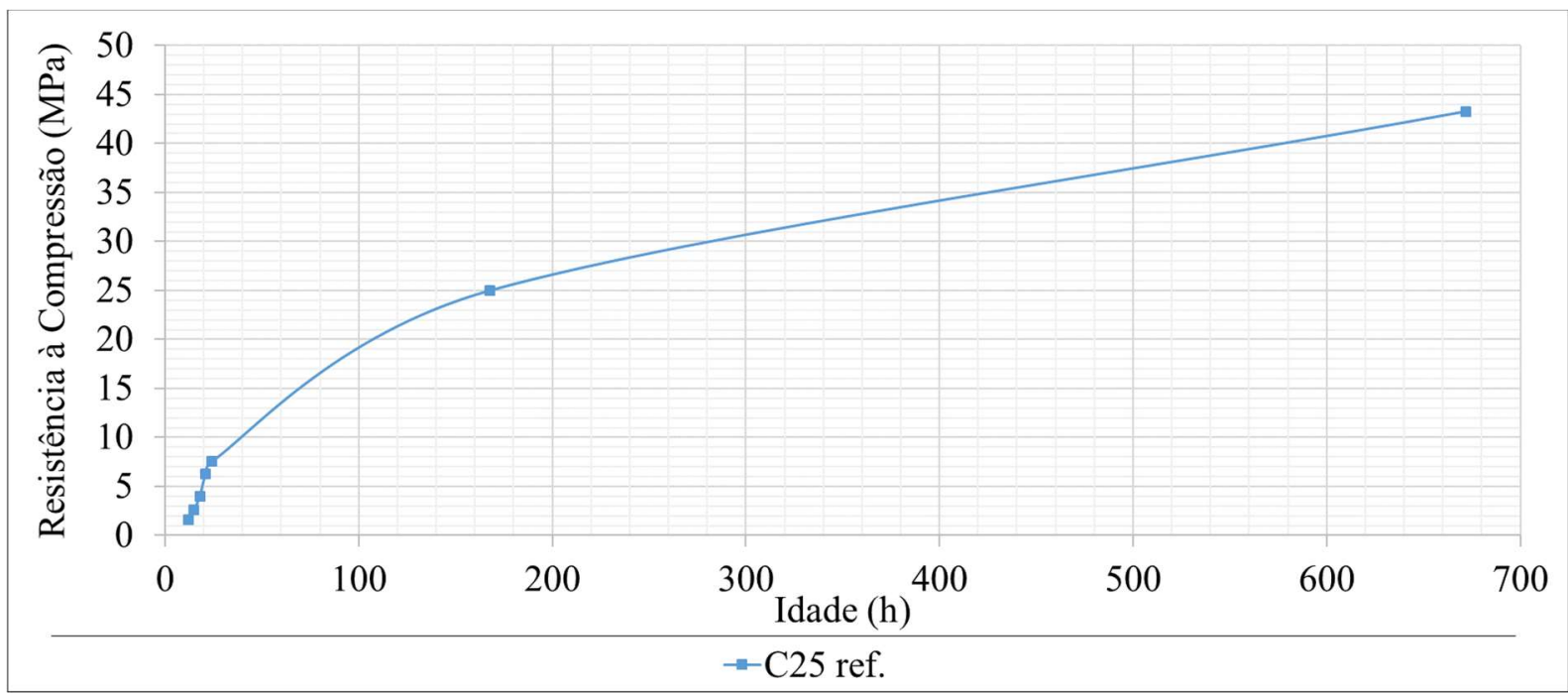

Fonte: Elaborada pelo autor. 
Segundo NBR 12655:2015, a resistência de dosagem deve atender às condições de variabilidade decorrentes da construção (ABNT, 2015b). Dessa forma, o valor da resistência média determinada em laboratório deve ser corrigido com um desvio padrão dependente da condição de preparo do concreto (Equação 4.1).

$$
f_{c k j}=f_{c m j}-1,65 . s_{d}
$$

Onde:

$f_{c m j}$ é a resistência média do concreto à compressão, prevista para a idade de $\mathrm{j}$ dias, expressa em megapascals (MPa);

$f_{c k j}$ é a resistência característica do concreto à compressão, aos j dias, expressa em megapascals (MPa);

$s_{d}$ é o desvio-padrão da dosagem, expresso em megapascals (MPa).

Para concretos nos quais o cimento e os agregados são medidos em massa e a água é medida em massa ou volume por meio de dispositivo dosador com correção em função da umidade dos agregados, o desvio padrão a ser considerado é de 4,0 MPa (ABNT, 2015b). Considera-se que essa situação é observada em paredes de concreto, pelo fato de se utilizar concreto usinado na sua execução.

Tem-se, então, aos 28 dias de idade, uma resistência característica calculada de 36,7 MPa para o concreto produzido. O valor ultrapassou o objetivo de $25 \mathrm{MPa}$ em cerca de 47\%. De acordo com Ghazi e Al Jadiri (2010), para a relação água/cimento utilizada $(0,55)$ era de se esperar um concreto com classe de resistência de $30 \mathrm{MPa}$. Ainda assim, esse traço foi considerado para o prosseguimento do trabalho pela expectativa de obtenção de resistências mínimas para consideração como concreto estrutural após a incorporação de ar.

Outra análise que pode ser feita é relacionada ao ganho de resistência em função do tempo para o concreto analisado. Segundo Battagin (2001), as resistências à compressão observadas para cimento CP II E 32 são de $23 \%$ com 1 dia e $74 \%$ aos 7 dias, quando em comparação com a resistência obtida aos 28 dias. Para o concreto C25 de referência, os valores obtidos para essas relações foram de $17,4 \%$ e $57,8 \%$, com 1 e 7 dias, respectivamente. Isso indica um ganho de resistência entre 7 e 28 dias que não era esperado.

Em relação às primeiras idades, os valores de interesse estão relacionados com 12 e 15 horas, pois são os valores mais próximos do que é normalmente observado para desforma das paredes em obra. Para 12 horas tem-se resistência à compressão média de 1,59 $\mathrm{MPa}$, enquanto que para 15 horas a resistência é de 2,65 MPa. O objetivo proposto inicialmente era 
de uma resistência à compressão mínima de 3,0 $\mathrm{MPa}$ com 12 horas, mas esse valor só foi ultrapassado com 18 horas (3,98 MPa). De qualquer forma, observa-se na literatura indicação de que a resistência à compressão com 12 horas pode ser considerada com valor mínimo de 1,0 MPa para permitir a desforma (SACHT, ROSSIGNOLO, 2008).

Tabela 4.10 - C25 referência - Resultados de resistência à tração por compressão diametral e na flexão aos 28 dias.

\begin{tabular}{ccc}
\hline \multicolumn{3}{c}{ Resistência à Tração aos 28 dias (MPa) } \\
\hline CP & Compressão Diametral & Flexão \\
\hline 1 & 3,99 & 5,25 \\
2 & 3,73 & 4,94 \\
3 & 3,74 & 5,14 \\
Média & 3,82 & 5,11 \\
Desvio Padrão & 0,15 & 0,16 \\
CV (\%) & 3,90 & 3,10 \\
\hline
\end{tabular}

Fonte: Elaborada pelo autor.

Pode-se observar certa variação entre as resistências à tração do concreto obtidas pelos dois métodos. A NBR 6118:2014 indica que a resistência à tração obtida com o ensaio de flexão $\left(f_{c t, f}\right)$ é maior do que a resistência observada para o ensaio por compressão diametral $\left(f_{c t, s p}\right)$, se relacionando com a resistência obtida à tração por ensaio direto $\left(f_{c t}\right)$ da seguinte maneira: $f_{c t}=0,9 \cdot f_{c t, s p}$ e $f_{c t}=0,7 \cdot f_{c t, f}(\mathrm{ABNT}, 2014 \mathrm{a})$.

Dessa forma, entende-se que o valor de $f_{c t, s p}$ deve ser da ordem de $78 \%$ de $f_{c t, f}$. A resistência média à tração por compressão diametral $\left(f_{c t m, s p}\right)$ obtida é de $3,82 \mathrm{MPa}$, o representa cerca de $75 \%$ da resistência média a tração por flexão $\left(f_{c t m, f}\right)$ com valor de $5,11 \mathrm{MPa}$. Essa porcentagem é muito próxima dos $78 \%$ esperados.

Price (1951) ${ }^{12}$ apud Mehta e Monteiro (2014), apresenta as seguintes correlações entre resistências à tração e à compressão (Tabela 4.11). 
Tabela 4.11 - Relação entre resistência à compressão e resistência à tração em concretos.

\begin{tabular}{cc}
\hline Resistência à compressão $(\mathrm{MPa})$ & Resistência à tração $(\mathrm{MPa})$ \\
\hline 7 & 1 \\
14 & 1 \\
21 & 2 \\
28 & 2 \\
34 & 3 \\
41 & 3 \\
48 & 4 \\
55 & 4 \\
62 & 4 \\
\hline
\end{tabular}

Fonte: Adaptado de Price (1951) apud Mehta e Monteiro (2014).

Considerando-se resistência à compressão média de 43,3 $\mathrm{MPa}$ aos 28 dias, a resistência à tração deve ser próxima de 3,3 $\mathrm{MPa}$ (considerando interpolação linear) de acordo com o apresentado na Tabela 4.11. Seguindo as relações propostas pela NBR 6118:2014, a resistência à tração média $\left(f_{c t, m}\right)$ é de $3,44 \mathrm{MPa}$ com base no valor de $f_{c t m, s p}$ e de $3,58 \mathrm{MPa}$ com base em $f_{c t m, f}$ (ABNT, 2014a). Observa-se como os valores experimentais estão próximos dos valores teóricos.

Tabela 4.12 - C25 referência - Resultados dos ensaios dinâmicos.

\begin{tabular}{ccccccccc}
\hline \multirow{2}{*}{ Parâmetros } & \multicolumn{7}{c}{ Idade } \\
\cline { 3 - 8 } & 12 horas & 15 horas & 18 horas & 21 horas & 24 horas & 7 dias & 28 dias \\
\hline \multirow{2}{*}{$\boldsymbol{E}_{\boldsymbol{F}}$} & Média & 13,35 & 15,36 & 17,12 & 18,49 & 19,44 & 34,11 & 38,75 \\
$(\mathbf{G P a})$ & Desvio Padrão & 1,34 & 0,95 & 0,67 & 0,67 & 0,60 & 0,23 & 0,38 \\
& CV (\%) & 10,05 & 6,19 & 3,91 & 3,65 & 3,09 & 0,7 & 1,0 \\
$\boldsymbol{E}_{\boldsymbol{L}}$ & Média & 12,97 & 15,11 & 16,54 & 17,97 & 18,92 & 32,71 & 37,18 \\
$(\mathbf{G P a})$ & Desvio Padrão & 1,40 & 1,00 & 0,69 & 0,74 & 0,65 & 0,26 & 0,44 \\
& CV (\%) & 10,78 & 6,62 & 4,19 & 4,10 & 3,45 & 0,8 & 1,2 \\
$\mathbf{G}$ & Média & - & - & 6,93 & 7,55 & 7,97 & 13,83 & 15,80 \\
$(\mathbf{G P a})$ & Desvio Padrão & - & - & 0,41 & 0,37 & 0,34 & 0,02 & 0,07 \\
& CV (\%) & - & - & 5,88 & 4,86 & 4,25 & 0,1 & 0,5 \\
& Média & - & - & 0,24 & 0,24 & 0,23 & 0,24 & 0,23 \\
$\boldsymbol{v}$ & Desvio Padrão & - & - & 0,01 & 0,01 & 0,02 & 0,01 & 0,01 \\
& CV (\%) & - & - & 4,88 & 2,44 & 6,55 & 2,4 & 4,9 \\
\hline
\end{tabular}

Fonte: Elaborada pelo autor.

Antes de analisar os resultados obtidos, vale ressaltar que o módulo de elasticidade flexional $\left(E_{F}\right)$ apresentado é referente à média dos valores obtidos nos três modos de vibração (flexional, longitudinal e torcional), enquanto que o módulo longitudinal $\left(E_{L}\right)$ é a média 
referente aos valores indicados no módulo de vibração longitudinal. As análises serão feitas considerando o módulo de elasticidade longitudinal, conforme Otani e Pereira (2017).

De acordo com Mehta e Monteiro (2014), o módulo de elasticidade dinâmico é dado aproximadamente pelo módulo de deformação tangente inicial e geralmente apresenta valores 20, 30 e 40\% superiores ao módulo de elasticidade estático para concretos de alta, média e baixa resistências à compressão, respectivamente. Ainda segundo os autores, concretos de baixa resistência são aqueles com resistência à compressão menor que $20 \mathrm{MPa}$, enquanto que os de média resistência se enquadram no intervalo de 20 a $40 \mathrm{MPa}$, e os de alta resistência acima de $40 \mathrm{MPa}$. Considerando-se a resistência característica à compressão de $25 \mathrm{MPa}$, inicialmente estabelecida a partir da escolha da classe de concreto (C25), o concreto produzido pode ser classificado como de média resistência.

Dessa maneira, pode-se considerar que o módulo de elasticidade dinâmico para o concreto desenvolvido é da ordem de $30 \%$ superior ao módulo de elasticidade estático. Seguindo o valor proposto, o módulo de elasticidade estático médio aos 28 dias seria da ordem de $26,0 \mathrm{GPa}$.

Conforme Otani e Pereira (2017) uma das principais equações para a previsão do módulo de elasticidade estático cordal $\left(E_{c}\right)$ em função do módulo dinâmico $\left(E_{d}\right)$ é dada por Popovics (1975):

$$
E_{c}=k \cdot E_{d}^{1,4} \cdot \rho^{-1}
$$

Onde $\rho$ é a densidade dada $\mathrm{em} \mathrm{kg} / \mathrm{m}^{3}$ e $k$ é uma constante de valor 0,107 quando o módulo é dado em Pa.

No concreto C25 de referência, os prismas ensaiados com 28 dias apresentavam densidade média de $2450 \mathrm{~kg} / \mathrm{m}^{3}$ (considerando dimensões de $15 \mathrm{~cm}$ x $15 \mathrm{~cm}$ x $50 \mathrm{~cm}$ ). Tem-se, assim, pela equação apresentada, que o módulo de elasticidade estático é de 27,5 GPa, próximo ao indicado por Mehta e Monteiro (2014).

Segundo a NBR 6118:2014, o módulo de elasticidade estático $\left(E_{c i}\right)$, considerando o módulo de deformação tangente inicial, pode ser determinado pelas seguintes equações (ABNT, 2014a):

$$
\begin{gathered}
E_{c i}=\alpha_{E} \cdot 5600 \cdot \sqrt{f_{c k}}, \text { para } f_{c k} \text { de } 20 \mathrm{MPa} \text { a } 50 \mathrm{MPa} \\
\text { e } \\
E_{c i}=21,5 \cdot 10^{3} \cdot \alpha_{E} \cdot\left(\frac{f_{c k}}{10}+1,25\right)^{1 / 3} \text {, para } f_{c k} \text { de } 55 \mathrm{MPa} \text { a } 90 \mathrm{MPa} \text {, sendo } E_{c i} \text { e } f_{c k} \\
\text { dados em MPa. }
\end{gathered}
$$


$\mathrm{O}$ valor de $\alpha_{E}$ deve ser considerado igual a 1,2 para agregado basáltico (ABNT, 2014a). Dessa maneira, para o $f_{c k}$ calculado de $36,7 \mathrm{MPa}$, tem-se $E_{c i}$ igual a 40,7 GPa. Vale a ressalva de que, caso fosse considerado o valor de $f_{c k}$ previsto inicialmente (25 $\mathrm{MPa}$ ), o $E_{c i}$ calculado seria de 33,6 GPa. Ainda assim, para efeitos de análises comparativas, o presente trabalho considerou o valor de $f_{c k}$ obtido experimentalmente nas relações que fazem uso da resistência característica à compressão. Dessa forma, o valor encontrado $(40,7 \mathrm{GPa})$ é bem diferente dos obtidos com as correlações anteriores e parecido com o valor do módulo dinâmico obtido em ensaios. Esse valor elevado pode ser explicado pelo fato de a referida norma não contemplar os concretos autoadensáveis, que contém um volume menor de agregado graúdo em sua composição que os concretos convencionais, fazendo com que a fórmula proposta para obtenção do módulo de elasticidade estático talvez não seja aplicável no concreto em análise. Ainda assim, esse método de determinação continuará a ser apresentado nos próximos traços para efeitos comparativos.

Entende-se que a maneira mais adequada de se estabelecer uma correlação direta entre os módulos de elasticidade estático e dinâmico depende da realização dos dois ensaios para o mesmo concreto.

Em relação ao módulo de cisalhamento (G), a NBR 6118:2014 apresenta que, para elementos sujeitos a tensões solicitantes de compressão menores que $50 \%$ da resistência à compressão, seu valor pode ser estimado como $E_{c s} / 2,4$, sendo $E_{c s}$ uma parcela de $E_{c i}$ dependente do valor de $f_{c k}(\mathrm{ABNT}, 2014 \mathrm{a})$.

$$
\begin{gathered}
E_{c s}=\alpha_{i} \cdot E_{c i} \\
\mathrm{e} \\
\alpha_{i}=0,8+0,2 \cdot \frac{f_{c k}}{80} \leq 1,0
\end{gathered}
$$

Assim, de acordo com $f_{c k}$ de $36,7 \mathrm{MPa}$ e módulo de elasticidade definido conforme NBR 6118:2014, tem-se que o módulo de cisalhamento pode ser estimado com valor de 15,1 GPa (ABNT, 2014a). Observa-se que o valor médio obtido para o módulo de cisalhamento dinâmico $(15,8 \mathrm{GPa})$ é muito próximo da estimativa feita para o módulo estático. Isso pode novamente ser explicado pelo fato de a NBR 6118:2014 não contemplar concretos autoadensáveis, de maneira que o valor de $E_{c i}$ considerado (e, consequentemente, o valor do módulo de cisalhamento dinâmico) pode não ser o mais correto. De qualquer maneira, o método apresentado será utilizado nas outras análises com fins comparativos. 
Em termos do coeficiente de Poisson, Mehta e Monteiro (2014) indicam que seu valor geralmente varia entre 0,15 e 0,20. A NBR 6118:2014 afirma que seu valor pode ser tomado como igual a 0,20 para tensões solicitantes de compressão menores que $50 \%$ da resistência à compressão (ABNT, 2014a).

Otani e Pereira (2017) afirmam que o coeficiente de Poisson $(v)$ definido pelo sistema Sonelastic considera a correlação entre os módulos de elasticidade e de cisalhamento, seguindo a Técnica de Excitação por Impulso apresentada na ASTM E 1876 (ASTM, 2015):

$$
v=\frac{E}{2 \cdot G}-1
$$

É importante ressaltar que, assim como informado pelo software Sonelastic no cálculo do coeficiente de Poisson, o material é considerado como sendo homogêneo e isotrópico, o que pode causar variações nas medições realizadas. Como pode ser visto na Tabela 4.12, os valores obtidos para os coeficientes de Poisson em todas as idades são mais altos que os valores indicados na literatura.

Tabela 4.13 - C25 referência - Resultados do ensaio de ultrassom.

\begin{tabular}{|c|c|c|c|c|c|c|c|c|}
\hline \multicolumn{9}{|c|}{ Velocidade do Pulso Ultrassônico (m/s) } \\
\hline \multirow{2}{*}{\multicolumn{2}{|c|}{ Direção }} & \multicolumn{7}{|c|}{ Idade } \\
\hline & & 12 horas & 15 horas & 18 horas & 21 horas & 24 horas & 7 dias & 28 dias \\
\hline \multirow{3}{*}{ Transversal } & Média & 3165,2 & 3332,0 & 3446,6 & 3511,5 & 3575,4 & 4285,1 & 4512,8 \\
\hline & $\begin{array}{l}\text { Desvio } \\
\text { Padrão }\end{array}$ & 138,8 & 95,4 & 83,1 & 61,3 & 92,0 & 71,1 & 49,2 \\
\hline & CV $(\%)$ & 4,39 & 2,86 & 2,41 & 1,75 & 2,57 & 1,7 & 1,1 \\
\hline \multirow{3}{*}{ Longitudinal } & Média & 3015,1 & 3142,4 & 3229,3 & 3321,7 & 3381,7 & 4257,6 & 4441,7 \\
\hline & $\begin{array}{l}\text { Desvio } \\
\text { Padrão }\end{array}$ & 81,3 & 84,3 & 35,2 & 25,3 & 28,9 & 27,8 & 31,1 \\
\hline & $\mathrm{CV}(\%)$ & 2,70 & 2,68 & 1,09 & 0,76 & 0,86 & 0,6 & 0,7 \\
\hline \multicolumn{2}{|l|}{ Média Geral } & 3090,1 & 3237,2 & 3338,0 & 3416,6 & 3478,5 & 4271,4 & 4477,3 \\
\hline \multicolumn{2}{|c|}{ Desvio Padrão Total } & 135,8 & 130,8 & 126,5 & 106,4 & 118,8 & 55,3 & 54,3 \\
\hline \multicolumn{2}{|l|}{ CV Total (\%) } & 4,40 & 4,04 & 3,79 & 3,11 & 3,41 & 1,3 & 1,2 \\
\hline
\end{tabular}

Assim como apresentado na Tabela 3.11, o valor da velocidade média do pulso ultrassônico no concreto aos 28 dias permite classificar o concreto proposto como sendo de boa qualidade, praticamente no limite de ser definido com excelente qualidade.

Outro fator que pode ser observado é a tendência de os valores de velocidades transversais serem maiores que os de velocidades longitudinais em todas as idades. Entende-se que esse fato seja explicado devido ao maior volume de amostra considerado na análise da 
direção longitudinal, de forma que a ocorrência de falhas nessa direção tende a ser maior. Assim, as velocidades observadas tendem a ser menores nas medições de maior comprimento.

Outras correlações de interesse entre velocidade e parâmetros físicos definidos serão abordadas mais à frente por meio da análise de gráficos comparativos.

- Concreto C40 de referência:

A apresentação dos resultados e análises comparativas com valores apresentados na literatura seguem o exposto para o concreto C25 de referência. Dessa forma, os valores de interesse serão mostrados aqui de maneira mais objetiva.

Tabela 4.14 - C40 referência - Resultados de resistência à compressão.

\begin{tabular}{cccccccc}
\hline \multicolumn{7}{c}{ Resistência à Compressão (MPa) } \\
\hline \multirow{2}{*}{ CP } & 1,60 & 3,46 & 6,43 & 9,18 & 11,86 & 40,92 & 62,61 \\
\cline { 2 - 8 } & 12 horas & 15 horas & 18 horas & 21 horas & 24 horas & 7 dias & 28 dias \\
\hline 1 & 1,70 & 3,68 & 6,38 & 8,97 & 11,74 & 43,79 & 60,75 \\
2 & 1,58 & 3,33 & 5,96 & 8,84 & 11,82 & 43,69 & 66,08 \\
3 & - & - & - & - & - & - & 62,42 \\
4 & - & - & - & - & - & - & 60,49 \\
5 & 1,62 & 3,49 & 6,26 & 9,00 & 11,81 & 42,80 & 62,47 \\
Média & 0,07 & 0,18 & 0,26 & 0,18 & 0,06 & 1,63 & 2,23 \\
Desvio Padrão & 4,03 & 5,05 & 4,16 & 1,95 & 0,52 & 3,80 & 3,60 \\
\hline CV (\%) & & & &
\end{tabular}

Fonte: Elaborada pelo autor.

Figura 4.7 - C40 referência - Evolução da resistência à compressão (valores médios) com o tempo.

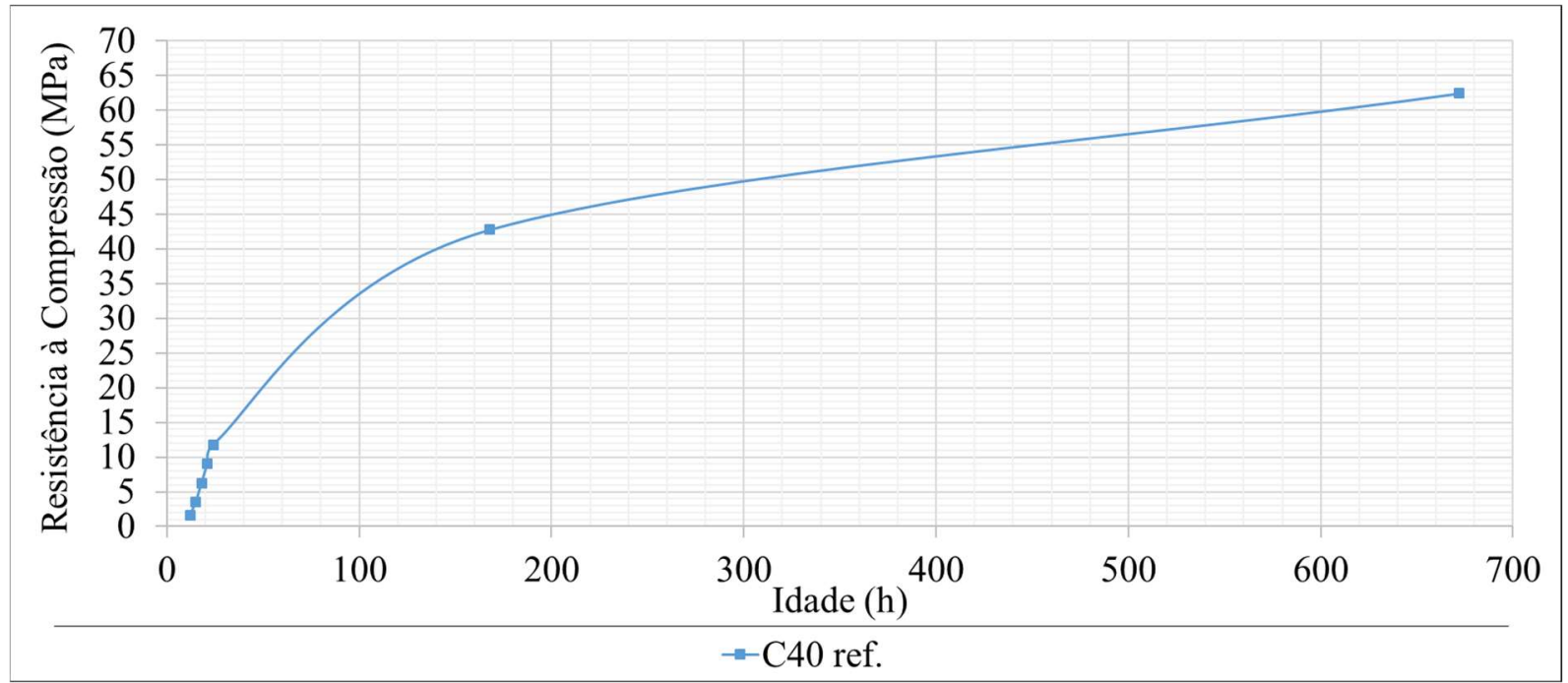

Fonte: Elaborada pelo autor. 
A partir da resistência à compressão média obtida aos 28 dias, determina-se o $f_{c k}$ para o concreto em questão como sendo de 55,9 MPa (ABNT, 2015b). O valor obtido ficou $40 \%$ acima do objetivo inicial. Esperava-se, de acordo com Ghazi e Al Jadiri (2010), que essa resistência ficasse próxima de $40 \mathrm{MPa}$ para relação água/cimento igual a 0,45 . Porém, assim como no caso do traço C25 de referência, o concreto aqui definido foi utilizado na continuação do trabalho devido à expectativa de se obter concretos de uso estrutural com a incorporação de ar em altos teores.

Em relação à evolução ao longo das idades, observa-se, em relação aos resultados de resistência à compressão aos 28 dias, valores de 18,9\% e 68,5\% para 1 e 7 dias, respectivamente. Os resultados são inferiores, mas próximos, à previsão de $23 \%$ e $74 \%$ para as respectivas idades presente em Battagin (2001).

As resistências médias nas idades de 12 e 15 horas apresentam valores de 1,62 e 3,49 MPa, respectivamente. Portanto, com 15 horas, o concreto proposto respeita a resistência mínima pretendida de 3,0 $\mathrm{MPa}$.

Tabela 4.15 - C40 referência - Resultados de resistência à tração por compressão diametral e na flexão aos 28 dias.

\begin{tabular}{ccc}
\hline \multicolumn{3}{c}{ Resistência à Tração aos 28 dias (MPa) } \\
\hline CP & Compressão Diametral & Flexão \\
\hline 1 & 4,70 & 8,70 \\
2 & 4,76 & 6,98 \\
3 & 4,64 & 8,01 \\
Média & 4,70 & 7,90 \\
Desvio Padrão & 0,06 & 0,86 \\
CV (\%) & 1,30 & 10,90 \\
\hline \multicolumn{3}{c}{}
\end{tabular}

Para as resistências à tração, tem-se que $f_{c t m, s p}$ é da ordem de $60 \%$ do valor de $f_{c t m, f}$. Dessa forma, essa relação ficou abaixo dos 78\% indicados pela NBR 6118:2014 (ABNT, 2014a).

Em relação às comparações possíveis com a resistência à compressão, era de se esperar, segundo Tabela 4.11, uma resistência à tração da ordem 4,0 MPa. Segundo a NBR 6118:2014, a resistência à tração média $\left(f_{c t, m}\right)$ é de 4,23 MPa com base no valor de $f_{c t m, s p} \mathrm{e}$ de 5,53 MPa com base em $f_{c t m, f}(\mathrm{ABNT}, 2014 \mathrm{a})$. 
Tabela 4.16 - C40 referência - Resultados dos ensaios dinâmicos.

\begin{tabular}{ccccccccc}
\hline \multirow{2}{*}{ Parâmetros } & \multicolumn{7}{c}{ Idade } \\
\cline { 3 - 8 } & 12 horas & 15 horas & 18 horas & 21 horas & 24 horas & 7 dias & 28 dias \\
\hline \multirow{2}{*}{$\boldsymbol{E}_{\boldsymbol{F}}$} & Média & 21,65 & 24,02 & 26,00 & 27,63 & 28,47 & 44,06 & 47,92 \\
$(\mathbf{G P a})$ & Desvio Padrão & 1,58 & 1,17 & 0,84 & 0,70 & 0,46 & 0,96 & 0,56 \\
& CV (\%) & 7,30 & 4,86 & 3,23 & 2,53 & 1,63 & 2,2 & 1,2 \\
$\boldsymbol{E}_{\boldsymbol{L}}$ & Média & 20,48 & 22,89 & 24,79 & 26,45 & 27,53 & 41,28 & 44,92 \\
$\mathbf{( G P a )}$ & Desvio Padrão & 1,43 & 1,27 & 1,28 & 0,67 & 0,89 & 0,29 & 0,03 \\
& CV (\%) & 6,99 & 5,53 & 5,15 & 2,52 & 3,23 & 0,7 & 0,1 \\
$\mathbf{G}$ & Média & 8,47 & 9,63 & 10,37 & 11,13 & 11,55 & 17,61 & 19,31 \\
$(\mathbf{G P a})$ & Desvio Padrão & 0,75 & 0,57 & 0,48 & 0,35 & 0,30 & 0,10 & 0,07 \\
& CV (\%) & 8,80 & 5,87 & 4,65 & 3,11 & 2,57 & 0,6 & 0,3 \\
& Média & 0,280 & 0,257 & 0,25 & 0,24 & 0,23 & 0,24 & 0,24 \\
$\boldsymbol{v}$ & Desvio Padrão & 0,05 & 0,03 & 0,03 & 0,02 & 0,02 & 0,02 & 0,02 \\
& CV (\%) & 16,37 & 9,80 & 13,03 & 8,55 & 7,53 & 6,4 & 6,4 \\
\hline
\end{tabular}

Fonte: Elaborada pelo autor.

Considerando-se $f_{c k}$ de 55,9 $\mathrm{MPa}$, o concreto em questão pode ser considerado como de alta resistência. Assim, o módulo de elasticidade médio obtido deve ser da ordem de 20\% superior ao módulo de elasticidade estático (MEHTA; MONTEIRO, 2014). Portanto, o valor de 44,9 GPa obtido para o módulo dinâmico representaria um valor estático equivalente da ordem de 35,9 GPa.

A densidade média obtida para os prismas do C40 de referência aos 28 dias foi de $2550 \mathrm{~kg} / \mathrm{m}^{3}$. Dessa forma, o módulo de elasticidade estático pode ser estimado em $34,4 \mathrm{GPa}$ (Equação 4.2), valor próximo ao obtido no parágrafo anterior.

Segundo a NBR 6118:2014, o módulo de elasticidade inicial estático $\left(E_{c i}\right)$, determinado em função do $f_{c k}$ é de 49,0 GPa (ABNT, 2014a). Novamente se observa que o valor encontrado é superior aos indicados anteriormente e próximo ao módulo dinâmico obtido nos ensaios.

O módulo de cisalhamento, definido de acordo com a NBR 6118:2014, é igual a 19,2 GPa (ABNT, 2014a). Esse valor é muito próximo ao módulo de cisalhamento dinâmico definido nos ensaios (19,3 GPa).

O coeficiente de Poisson apresenta valores médios superiores ao valor de 0,20 definido anteriormente. Essa diferença pode ser novamente justificada pelo fato de o concreto não ser um material homogêneo nem isotrópico. 
Tabela 4.17 - C40 referência - Resultados do ensaio de ultrassom.

\begin{tabular}{|c|c|c|c|c|c|c|c|c|}
\hline \multicolumn{9}{|c|}{ Velocidade do Pulso Ultrassônico (m/s) } \\
\hline \multirow{2}{*}{\multicolumn{2}{|c|}{ Direção }} & \multicolumn{7}{|c|}{ Idade } \\
\hline & & 12 horas & 15 horas & 18 horas & 21 horas & 24 horas & 7 dias & 28 dias \\
\hline \multirow{3}{*}{ Transversal } & Média & 3672,5 & 3784,1 & 3885,3 & 3984,2 & 4010,6 & 4585,9 & 4731,0 \\
\hline & $\begin{array}{l}\text { Desvio } \\
\text { Padrão }\end{array}$ & 88,4 & 78,5 & 73,5 & 51,6 & 54,3 & 36,4 & 40,2 \\
\hline & CV $(\%)$ & 2,41 & 2,07 & 1,89 & 1,30 & 1,35 & 0,8 & 0,8 \\
\hline \multirow{3}{*}{ Longitudinal } & Média & 3500,5 & 3638,8 & 3749,9 & 3868,8 & 3910,2 & 4538,0 & 4692,4 \\
\hline & $\begin{array}{l}\text { Desvio } \\
\text { Padrão }\end{array}$ & 60,7 & 48,2 & 32,2 & 21,8 & 21,4 & 18,4 & 15,3 \\
\hline & $\mathrm{CV}(\%)$ & 1,73 & 1,33 & 0,86 & 0,56 & 0,55 & 0,4 & 0,3 \\
\hline \multicolumn{2}{|l|}{ Média Geral } & 3586,5 & 3711,5 & 3817,6 & 3926,5 & 3960,4 & 4562,0 & 4711,7 \\
\hline \multicolumn{2}{|c|}{ Desvio Padrão Total } & 114,7 & 97,7 & 88,5 & 70,2 & 65,1 & 37,4 & 35,9 \\
\hline \multicolumn{2}{|l|}{ CV Total (\%) } & 3,20 & 2,63 & 2,32 & 1,79 & 1,64 & 0,8 & 0,8 \\
\hline
\end{tabular}

De acordo com a Tabela 3.11, o valor da velocidade média observado aos 28 dias permite classificar o concreto proposto como sendo de excelente qualidade, já que a velocidade observada é superior a $4572 \mathrm{~m} / \mathrm{s}$.

É possível identificar também a tendência de a velocidade transversal ser maior que a velocidade longitudinal para todas as idades.

Com todas as análises apresentadas até aqui, verificou-se que os dois traços respeitavam o limitante de resistência à compressão aos 28 dias definido previamente. Dessa forma, o próximo passo foi a modificação dos traços com incorporação de ar.

\subsection{Caracterização dos concretos com ar incorporado}

O procedimento de incorporação de ar aos traços de referência demandou alguns testes para interpretar qual seria a resposta dos concretos em estado fresco. Inicialmente foram feitos teste em misturador planetário de baixa capacidade, utilizando amostras de $2000 \mathrm{~g}$. Isso foi feito para definir o tempo de mistura e a quantidade de aditivo incorporador de ar necessários para alcançar os teores de ar desejados (9\% e 15\%), sem perder muito material no processo.

O procedimento de mistura foi o mesmo apresentado para os traços de referência nos ensaios anteriores. Após o tempo de mistura do superplastificante, foi adicionado o aditivo incorporador de ar e a mistura seguiu por mais 3 minutos. Após esse tempo o concreto era pesado para definição do teor de ar conforme NBR 9833:2008 (ABNT, 2008b). A ideia inicial 
era utilizar o aditivo com variação de $0,1 \%$ até $0,6 \%$ em relação à massa de cimento, conforme informações do fabricante ${ }^{13}$. Mas devido à pouca variação dos resultados, foi considerado um valor extrapolado de $1,0 \%$ para confirmar a estabilização. Os resultados estão apresentados na Tabela 4.18.

Tabela 4.18 - Teores de ar incorporado aos traços de referência (produzido em misturador planetário).

\begin{tabular}{lccccccccccc}
\hline Aditivo/Cimento (\%) & 0,0 & 0,1 & 0,2 & 0,3 & 0,4 & 0,5 & 0,6 & 0,7 & 0,8 & 0,9 & 1,0 \\
Teor de ar (\%) [C25] & 0,7 & 2,7 & 4,8 & 5,8 & 6,5 & 6,3 & 6,4 & - & - & - & 6,3 \\
Teor de ar (\%) [C40] & 0,6 & 9,5 & 13,4 & 13,5 & 13,3 & - & - & - & - & - & 13,5 \\
\hline \multicolumn{1}{c}{ Fonte: Elaborada pelo autor. }
\end{tabular}

Após a realização dos testes com pequeno volume, optou-se pela realização de teste em betoneira com volume maior. Isso porque com o ensaio em misturador planetário não foi possível a obtenção de alto teor de ar, isto é, $15 \%$. Nesse ensaio, o volume misturado foi de 30 litros, sendo o concreto produzido em uma betoneira de eixo vertical. As quantidades de aditivo/cimento adotadas foram de $0,2 \%$ e $0,1 \%$ para os traços $\mathrm{C} 25$ e C40, respectivamente. Os resultados da mistura estão apresentados na Tabela 4.19.

Tabela 4.19 - Teores de ar incorporado aos traços de referência com mistura em betoneira.

\begin{tabular}{cccccc}
\hline Tempo (min) & 0 & 3 & 5 & 10 & 12 \\
Teor de $\operatorname{ar}(\%)[\mathbf{C 2 5}]$ & 0,6 & 5,7 & 8,2 & 13,3 & 15,9 \\
\hline Teor de $\operatorname{ar}(\%)[\mathbf{C 4 0}]$ & 0,5 & 7,8 & 10,4 & 14,4 & 15,0 \\
\hline
\end{tabular}

Fonte: Elaborada pelo autor.

As medidas com tempo de 0 minutos são referentes a pesagens realizadas antes da colocação do aditivo incorporador de ar. Tem-se, então, um valor de ar decorrente do aprisionamento de bolhas de ar durante a mistura.

Ao se comparar os teores de ar obtidos após 3 minutos de mistura na betoneira (Tabela 4.19) com os valores equivalentes na Tabela 4.18, observa-se que a mudança de escala interferiu na quantidade de ar incorporado. No caso do traço C25, o teor de ar obtido foi maior para a betoneira $(5,7 \%)$ em relação ao misturador planetário $(4,8 \%)$. Já para o traço C40, a situação se inverteu, com incorporação menor na betoneira $(7,8 \%)$ quando comparado ao misturador planetário $(9,5 \%)$. Com isso, pode-se extrair que o volume de mistura afeta a capacidade de incorporação de ar por parte do concreto.

13 GCPAT. DARAFILL. Aditivo incorporador de ar. Disponível em <https://gcpat.com.br/ptbr/solutions/products/darafill-0> acesso em: 17 de março de 2019. 
Um fator que se mostrou constante nos dois métodos de mistura foi a tendência do traço C25 incorporar menos ar que o traço C40, levando-se em conta as variáveis de tempo e quantidade de aditivo. Isso permite entender que as quantidades de água e de aditivo superplastificante consideradas interferem na incorporação de ar, uma vez que o consumo de cimento é praticamente igual para as duas misturas.

Assim, fica evidente a dificuldade de se trabalhar com o aditivo incorporador de ar visando teores específicos de ar para cada traço envolvido. A solução encontrada para permitir o desenvolvimento do trabalho foi utilizar uma balança próxima da betoneira de maneira a permitir medições constantes de massa à medida que o material fosse misturado, a fim de controlar o teor de ar incorporado às misturas.

Optou-se por 4 betonadas de 30 litros por traço para produzir o volume exigido pelos ensaios. Decidiu-se também pela limitação de uma variação de $2 \%$ (em valor de teor de ar) a ser respeitado entre as quatro betonadas de um mesmo traço devido às difículdades relacionadas ao trabalho com o aditivo incorporador de ar.

Para efeitos de interpretação dos resultados, os traços obtidos a partir daqui serão denominados com base nos traços de referência, de acordo com os teores de ar definidos inicialmente. Dessa forma, o traço C25 de referência deu origem aos traços "C25 9\%" e "C25 15\%", enquanto que o traço C40 de referência resultou nos traços "C40 9\%" e "C40 15\%". É importante ressaltar que as porcentagens utilizadas na nomenclatura remetem aos objetivos originais e não necessariamente aos teores de ar obtidos após ensaios.

\subsubsection{Propriedades do concreto em estado fresco para traços com ar incorporado}

Na sequência são apresentados os resultados de caracterização em estado fresco para os quatro traços modificados a partir dos traços de referência. Estão apresentados também os teores de ar médios obtidos a cada betonada por meio de duas medições de massa. Vale destacar que a betoneira era desligada durante as pesagens para que não houvesse incorporação de ar durante o tempo necessário para obtenção das massas.

\section{- Concreto C25 9\%:}

Nesse concreto, foi utilizada massa de aditivo incorporador de ar correspondente a um teor igual a $0,2 \%$ da massa de cimento, com tempo de mistura efetivo de aproximadamente 7 minutos após colocação do aditivo, totalizando mistura de 21 minutos. 
Tabela 4.20 - C25 9\% - Caracterização do concreto autoadensável em estado fresco.

\begin{tabular}{|c|c|c|c|c|c|c|}
\hline \multicolumn{2}{|c|}{ Parâmetros } & $\begin{array}{c}\text { Limites } \\
\text { Considerados }\end{array}$ & $\begin{array}{l}\text { Primeira } \\
\text { Betonada }\end{array}$ & $\begin{array}{c}\text { Segunda } \\
\text { Betonada }\end{array}$ & $\begin{array}{r}\text { Terceira } \\
\text { Betonada }\end{array}$ & $\begin{array}{c}\text { Quarta } \\
\text { Betonada }\end{array}$ \\
\hline \multirow{3}{*}{$\begin{array}{l}\text { Slump } \\
\text { flow }\end{array}$} & Medida $1(\mathrm{~mm})$ & - & 670 & - & 690 & 740 \\
\hline & Medida $2(\mathrm{~mm})$ & - & 660 & - & 700 & 750 \\
\hline & Média (mm) & 760 a $850 \mathrm{~mm}$ & 665 & - & 695 & 745 \\
\hline \multicolumn{2}{|l|}{$T_{500}(s)$} & $\leq 2 \mathrm{~s}$ & 0,97 & - & - & - \\
\hline \multicolumn{2}{|l|}{ IEV } & Estável & Estável & Estável & Estável & Estável \\
\hline \multirow{4}{*}{ Anel J } & Medida $1(\mathrm{~mm})$ & - & - & 650 & - & - \\
\hline & Medida $2(\mathrm{~mm})$ & - & - & 640 & - & - \\
\hline & Média (mm) & - & - & 645 & - & - \\
\hline & Slump flow - Anel J & 0 a $25 \mathrm{~mm}$ & - & - & - & - \\
\hline \multirow{3}{*}{ Caixa $L$} & $\mathrm{H} 1$ & - & 9 & - & - & - \\
\hline & $\mathrm{H} 2$ & - & 6,5 & - & - & - \\
\hline & $\mathrm{H} 2$ / H1 & $\geq 0,80$ & 0,72 & - & - & - \\
\hline \multicolumn{2}{|l|}{ Funil V (s) } & $<9 \mathrm{~s}$ & 2,81 & - & - & - \\
\hline \multirow{3}{*}{$\begin{array}{l}\text { Coluna de } \\
\text { Segregação }\end{array}$} & Massa topo (kg) & - & 4,25 & - & - & - \\
\hline & Massa base (kg) & - & 4,50 & - & - & - \\
\hline & $\begin{array}{c}\text { Massa topo / Massa } \\
\text { base }(\%)\end{array}$ & $\leq 15 \%$ & 5,6 & - & - & - \\
\hline \multirow{8}{*}{$\begin{array}{l}\text { Teor de Ar } \\
(\%)\end{array}$} & Medida 1 & - & 6,5 & 5,6 & 5,6 & 4,1 \\
\hline & Medida 2 & - & 6,0 & 5,5 & 5,6 & 4,8 \\
\hline & Média & - & 6,2 & 5,5 & 5,6 & 4,4 \\
\hline & Desvio Padrão & - & 0,34 & 0,06 & 0,00 & 0,49 \\
\hline & $\mathrm{CV}(\%)$ & - & 5,54 & 1,05 & 0,03 & 11,07 \\
\hline & Média Geral & - & \multicolumn{4}{|c|}{5,4} \\
\hline & Desvio Padrão Total & - & \multicolumn{4}{|c|}{0,74} \\
\hline & CV Total (\%) & - & \multicolumn{4}{|c|}{13,51} \\
\hline
\end{tabular}

Fonte: Elaborada pelo autor.

A partir dos resultados obtidos (Tabela 4.20), observa-se uma redução no valor de espalhamento em comparação ao C25 referência. Esse dado apresenta diferenças em relação ao que é esperado segundo Kosmatka, Kerkhoff e Panarese (2002). Conforme Tabela 2.3, o abatimento do concreto deveria aumentar com o aumento no teor de ar. Entende-se, portanto, que o mesmo efeito deveria ser observado para o espalhamento. Essa diferença pode ser explicada pelo maior tempo de mistura necessário após a adição do incorporador de ar, fazendo com que o superplastificante perdesse eficiência. Essa perda de fluidez é observada também no ensaio com caixa L, dado que o resultado obtido está aquém do limite inferior. Cabe ressaltar que o teor de aditivo superplastificante foi mantido o mesmo do concreto de referência quando 
da produção dos traços modificados com aditivo incorporador de ar, a fim de verificar o efeito desse aditivo sobre o comportamento dos concretos autoadensáveis.

Os resultados indicam também que o teor de ar incorporado apresentou certa variação ao longo das quatro betonadas. Ainda assim, a diferença entre a média mais alta e a mais baixa é inferior a 2\% (em valor de teor de ar), limite definido anteriormente para aceitação ou não dos concretos modificados.

Outra observação importante é referente ao teor médio de ar incorporado que ficou bem abaixo do objetivo (9\%). Os tempos de mistura e quantidade de aditivo adotados foram considerados com base em testes feitos em betoneira, conforme Tabela 4.19. Porém, observouse redução do teor de ar em relação ao esperado. Para não comprometer o desenvolvimento do trabalho, esse teor de ar médio abaixo da expectativa de $9 \%$ foi considerado válido. Essa escolha se justifica ainda pela possibilidade de alcançar resistências maiores com a menor incorporação de ar. Vale destacar que, para esse teor de ar incorporado, o consumo de cimento passou a ser de $348 \mathrm{~kg} / \mathrm{m}^{3}$ no traço proposto, conforme NBR 9833:2008 (ABNT, 2008b).

\section{- Concreto C25 15\%:}

Nesse concreto, foi utilizada massa de aditivo incorporador de ar correspondente a um teor igual a $0,2 \%$ da massa de cimento, com tempo de mistura efetivo de aproximadamente 10 minutos após colocação do aditivo, totalizando mistura de 24 minutos.

Conforme Tabela 4.21, novamente é observada uma redução do espalhamento em relação ao C25 referência, justificada com o maior tempo de mistura, uma vez que o teor de aditivo foi mantido o mesmo da mistura de referência. O ensaio de Caixa L também mostra que o resultado ficou prejudicado com a perda de fluidez.

O teor de ar médio obtido também foi inferior aos $15 \%$ incialmente estabelecidos. Porém, assim como no caso do $\mathrm{C} 259 \%$, os resultados foram considerados válidos pela expectativa de menor perda de resistência em comparação a um possível traço com $15 \%$ de ar incorporado. Com esse teor de ar, o consumo de cimento para o C25 15\% ficou igual a $325 \mathrm{~kg} / \mathrm{m}^{3}$ (ABNT, 2008b). 
Tabela 4.21 - C25 15\% - Caracterização do concreto autoadensável em estado fresco.

\begin{tabular}{|c|c|c|c|c|c|c|}
\hline \multicolumn{2}{|c|}{ Parâmetros } & $\begin{array}{c}\text { Limites } \\
\text { Considerados }\end{array}$ & $\begin{array}{l}\text { Primeira } \\
\text { Betonada }\end{array}$ & $\begin{array}{l}\text { Segunda } \\
\text { Betonada }\end{array}$ & $\begin{array}{l}\text { Terceira } \\
\text { Betonada }\end{array}$ & $\begin{array}{c}\text { Quarta } \\
\text { Betonada }\end{array}$ \\
\hline \multirow{3}{*}{$\begin{array}{l}\text { Slump } \\
\text { flow }\end{array}$} & Medida $1(\mathrm{~mm})$ & - & 710 & - & 690 & 680 \\
\hline & Medida $2(\mathrm{~mm})$ & - & 740 & - & 680 & 670 \\
\hline & Média (mm) & 760 a $850 \mathrm{~mm}$ & 725 & - & 685 & 675 \\
\hline \multicolumn{2}{|l|}{$T_{500}(s)$} & $\leq 2 \mathrm{~s}$ & 0,76 & - & - & - \\
\hline \multicolumn{2}{|l|}{ IEV } & Estável & Estável & Estável & Estável & Estável \\
\hline \multirow{4}{*}{ Anel J } & Medida $1(\mathrm{~mm})$ & - & - & 670 & - & - \\
\hline & Medida $2(\mathrm{~mm})$ & - & - & 660 & - & - \\
\hline & Média (mm) & - & - & 665 & - & - \\
\hline & Slump flow - Anel J & 0 a $25 \mathrm{~mm}$ & - & - & - & - \\
\hline \multirow{3}{*}{ Caixa $\mathbf{L}$} & H1 & - & 9 & - & - & - \\
\hline & $\mathrm{H} 2$ & - & 7 & - & - & - \\
\hline & $\mathrm{H} 2$ / H1 & $\geq 0,80$ & 0,78 & - & - & - \\
\hline \multicolumn{2}{|l|}{ Funil V (s) } & $<9 \mathrm{~s}$ & 3,13 & - & - & - \\
\hline \multirow{3}{*}{$\begin{array}{l}\text { Coluna de } \\
\text { Segregação }\end{array}$} & Massa topo $(\mathrm{kg})$ & - & 4,15 & - & - & - \\
\hline & Massa base $(\mathrm{kg})$ & - & 4,50 & - & - & - \\
\hline & $\begin{array}{c}\text { Massa topo / Massa } \\
\text { base }(\%)\end{array}$ & $\leq 15 \%$ & 7,8 & - & - & - \\
\hline \multirow{8}{*}{$\begin{array}{l}\text { Teor de Ar } \\
(\%)\end{array}$} & Medida 1 & - & 12,0 & 12,1 & 11,4 & 11,1 \\
\hline & Medida 2 & - & 12,3 & 11,7 & 11,5 & 11,1 \\
\hline & Média & - & 12,1 & 11,9 & 11,5 & 11,1 \\
\hline & Desvio Padrão & - & 0,28 & 0,25 & 0,13 & 0,02 \\
\hline & $\mathrm{CV}(\%)$ & - & 2,26 & 2,12 & 1,12 & 0,22 \\
\hline & Média Geral & - & \multicolumn{4}{|c|}{11,7} \\
\hline & Desvio Padrão Total & - & \multicolumn{4}{|c|}{0,45} \\
\hline & CV Total $(\%)$ & - & \multicolumn{4}{|c|}{3,84} \\
\hline
\end{tabular}

Fonte: Elaborada pelo autor.

- Concreto C40 9\%:

Nesse concreto, foi utilizada massa de aditivo incorporador de ar correspondente a um teor igual a $0,1 \%$ da massa de cimento, com tempo de mistura efetivo de aproximadamente 6 minutos após colocação do aditivo, totalizando mistura de 20 minutos. 
Tabela 4.22 - C40 9\% - Caracterização do concreto autoadensável em estado fresco.

\begin{tabular}{|c|c|c|c|c|c|c|}
\hline \multicolumn{2}{|r|}{ Parâmetros } & $\begin{array}{c}\text { Limites } \\
\text { Considerados }\end{array}$ & $\begin{array}{l}\text { Primeira } \\
\text { Betonada }\end{array}$ & $\begin{array}{l}\text { Segunda } \\
\text { Betonada }\end{array}$ & $\begin{array}{l}\text { Terceira } \\
\text { Betonada }\end{array}$ & $\begin{array}{c}\text { Quarta } \\
\text { Betonada }\end{array}$ \\
\hline \multirow{3}{*}{$\begin{array}{l}\text { Slump } \\
\text { flow }\end{array}$} & Medida $1(\mathrm{~mm})$ & - & 570 & - & 690 & 680 \\
\hline & Medida $2(\mathrm{~mm})$ & - & 550 & - & 700 & 700 \\
\hline & Média (mm) & 760 a $850 \mathrm{~mm}$ & 560 & - & 695 & 690 \\
\hline \multicolumn{2}{|l|}{$T_{500}(s)$} & $\leq 2 \mathrm{~s}$ & 1,24 & - & - & - \\
\hline \multicolumn{2}{|l|}{ IEV } & Estável & Estável & Estável & Estável & Estável \\
\hline \multirow{4}{*}{ Anel J } & Medida $1(\mathrm{~mm})$ & - & - & 540 & - & - \\
\hline & Medida $2(\mathrm{~mm})$ & - & - & 530 & - & - \\
\hline & Média (mm) & - & - & 535 & - & - \\
\hline & Slump flow - Anel J & 0 a $25 \mathrm{~mm}$ & - & - & - & - \\
\hline \multirow{3}{*}{ Caixa $L$} & H1 & - & 11 & - & - & - \\
\hline & $\mathrm{H} 2$ & - & 9,5 & - & - & - \\
\hline & $\mathrm{H} 2$ / H1 & $\geq 0,80$ & 0,86 & - & - & - \\
\hline \multicolumn{2}{|l|}{ Funil V (s) } & $<9 \mathrm{~s}$ & 5,86 & - & - & - \\
\hline \multirow{3}{*}{$\begin{array}{l}\text { Coluna de } \\
\text { Segregação }\end{array}$} & Massa topo $(\mathrm{kg})$ & - & 4,35 & - & - & - \\
\hline & Massa base $(\mathrm{kg})$ & - & 4,85 & - & - & - \\
\hline & $\begin{array}{c}\text { Massa topo / Massa } \\
\text { base (\%) }\end{array}$ & $\leq 15 \%$ & 10,3 & - & - & - \\
\hline \multirow{8}{*}{$\begin{array}{l}\text { Teor de Ar } \\
(\%)\end{array}$} & Medida 1 & - & 9,3 & 9,4 & 9,1 & 9,3 \\
\hline & Medida 2 & - & 8,4 & 9,2 & 8,4 & 9,0 \\
\hline & Média & - & 8,8 & 9,3 & 8,8 & 9,2 \\
\hline & Desvio Padrão & - & 0,65 & 0,15 & 0,54 & 0,23 \\
\hline & CV $(\%)$ & - & 7,42 & 1,61 & 6,11 & 2,47 \\
\hline & Média Geral & - & \multicolumn{4}{|c|}{9,0} \\
\hline & Desvio Padrão Total & - & \multicolumn{4}{|c|}{0,42} \\
\hline & CV Total (\%) & - & \multicolumn{4}{|c|}{4,69} \\
\hline
\end{tabular}

Fonte: Elaborada pelo autor.

É importante destacar que a primeira e a segunda betonada ficaram menos fluidas pois a medição das massas estava sendo feita com balança longe da betoneira, resultando em um maior tempo com a betoneira parada. De maneira geral, o espalhamento observado foi menor do que no C40 referência. Assim como no caso dos outros traços modificados, essa variação pode ser explicada pelo maior tempo total de mistura, uma vez que o teor de aditivo foi mantido o mesmo da mistura de referência.

Em relação aos outros parâmetros, os limites considerados foram respeitados. $\mathrm{O}$ teor de ar, inclusive, apresentou valor médio de $9 \%$, igual ao pretendido por esse trabalho. Para esse teor de ar e para a quantidade dos outros componentes da mistura, a NBR 9833:2008 indica um consumo de cimento igual a $333 \mathrm{~kg} / \mathrm{m}^{3}$ no traço analisado (ABNT, 2008b). 
- Concreto C40 15\%:

Nesse concreto, foi utilizada massa de aditivo incorporador de ar correspondente a um teor igual a $0,2 \%$ da massa de cimento, com tempo de mistura efetivo de aproximadamente 8 minutos após colocação do aditivo, totalizando mistura de 22 minutos.

Da mesma maneira que observado nos outros 3 traços modificados, o C40 15\% (Tabela 4.23) apresentou perda de espalhamento em relação ao traço de referência. O ensaio da caixa L, novamente refletiu esse resultado, apresentando valor ligeiramente inferior ao limite mínimo.

Tabela 4.23 - C40 15\% - Caracterização do concreto autoadensável em estado fresco.

\begin{tabular}{|c|c|c|c|c|c|c|}
\hline \multicolumn{2}{|c|}{ Parâmetros } & $\begin{array}{c}\text { Limites } \\
\text { Considerados }\end{array}$ & $\begin{array}{l}\text { Primeira } \\
\text { Betonada }\end{array}$ & $\begin{array}{c}\text { Segunda } \\
\text { Betonada }\end{array}$ & $\begin{array}{c}\text { Terceira } \\
\text { Betonada }\end{array}$ & $\begin{array}{c}\text { Quarta } \\
\text { Betonada }\end{array}$ \\
\hline \multirow{3}{*}{$\begin{array}{l}\text { Slump } \\
\text { flow }\end{array}$} & Medida $1(\mathrm{~mm})$ & - & 580 & 600 & - & 610 \\
\hline & Medida $2(\mathrm{~mm})$ & - & 570 & 600 & - & 610 \\
\hline & Média (mm) & 760 a $850 \mathrm{~mm}$ & 575 & 600 & - & 610 \\
\hline \multicolumn{2}{|l|}{$T_{500}(s)$} & $\leq 2 \mathrm{~s}$ & 1,53 & - & - & - \\
\hline \multicolumn{2}{|l|}{ IEV } & Estável & Estável & Estável & Estável & Estável \\
\hline \multirow{4}{*}{ Anel J } & Medida $1(\mathrm{~mm})$ & - & - & - & 580 & - \\
\hline & Medida $2(\mathrm{~mm})$ & - & - & - & 600 & - \\
\hline & Média (mm) & - & - & - & 590 & - \\
\hline & Slump flow - Anel J & 0 a $25 \mathrm{~mm}$ & - & - & - & - \\
\hline \multirow{3}{*}{ Caixa $L$} & H1 & - & 10,5 & - & - & - \\
\hline & $\mathrm{H} 2$ & - & 8 & - & - & - \\
\hline & $\mathrm{H} 2$ / H1 & $\geq 0,80$ & 0,76 & - & - & - \\
\hline \multicolumn{2}{|l|}{ Funil V (s) } & $<9 \mathrm{~s}$ & 3,41 & - & - & - \\
\hline \multirow{3}{*}{$\begin{array}{l}\text { Coluna de } \\
\text { Segregação }\end{array}$} & Massa topo $(\mathrm{kg})$ & - & 4,20 & - & - & - \\
\hline & Massa base (kg) & - & 4,40 & - & - & - \\
\hline & $\begin{array}{c}\text { Massa topo / Massa } \\
\text { base }(\%)\end{array}$ & $\leq 15 \%$ & 4,5 & - & - & - \\
\hline \multirow{8}{*}{$\begin{array}{l}\text { Teor de Ar } \\
(\%)\end{array}$} & Medida 1 & - & 14,4 & 14,7 & 14,0 & 13,6 \\
\hline & Medida 2 & - & 14,1 & 14,2 & 13,7 & 14,4 \\
\hline & Média & - & 14,2 & 14,4 & 13,9 & 14,0 \\
\hline & Desvio Padrão & - & 0,24 & 0,36 & 0,17 & 0,56 \\
\hline & $\mathrm{CV}(\%)$ & - & 1,67 & 2,52 & 1,25 & 3,97 \\
\hline & Média Geral & - & \multicolumn{4}{|c|}{14,1} \\
\hline & Desvio Padrão Total & - & \multicolumn{4}{|c|}{0,36} \\
\hline & CV Total (\%) & - & \multicolumn{4}{|c|}{2,55} \\
\hline
\end{tabular}


Em relação ao teor de ar incorporado no concreto C40 15\%, o valor médio está dentro da tolerância de $2 \%$ (em valor de teor de ar) quando comparado com o teor alvo de $15 \%$ proposto inicialmente. O consumo de cimento com teor de ar incorporado igual a $14,1 \%$ passou a ser de $314 \mathrm{~kg} / \mathrm{m}^{3}$ (ABNT, 2008b).

Em uma análise geral, os concretos C25 9\%, C25 15\% e C40 15\% apresentaram resultado do ensaio de caixa L um pouco abaixo do esperado. Com exceção do espalhamento, os outros parâmetros analisados respeitam os limites impostos em todos os 4 concretos, sendo que vale chamar atenção para o anel $\mathrm{J}$, que não possui uma comparação direta com o espalhamento na mesma betonada. No caso desse ensaio, considera-se que o limite de $25 \mathrm{~mm}$ é respeitado com ao menos um dos espalhamentos obtidos em outras betonadas.

No caso do espalhamento, nenhum dos traços com ar incorporado atingiu o valor mínimo de $750 \mathrm{~mm}$ que os enquadraria na classe SF3. Isso faz com que, para o uso específico em paredes de concreto, os valores de espalhamento fiquem abaixo do limite inferior proposto nesse trabalho. Ainda assim, todos os concretos produzidos apresentam espalhamento que permite sua classificação como autoadensáveis, ou seja, classe SF1. Como mostrado em Monge e Wendler (2018), essa classe já seria adequada para a construção das paredes.

Como o teor de aditivo superplastificante foi mantido o mesmo do concreto de referência quando da produção dos traços modificados com aditivo incorporador de ar, para adequar as propriedades de autoadensabilidade dos traços modificados aos limites e classificações estabelecidas no presente trabalho, o teor de superplastificante poderia ser ajustado para cada mistura. Esse procedimento foi adotado para a concretagem dos painéis de paredes, isto é, a quantidade de superplastificante foi ajustada para que o espalhamento fosse maior, a fim de facilitar o processo de moldagem. Esse assunto será abordado mais à frente.

Para uma análise comparativa entre os 4 traços modificados, os teores de ar incorporado, o consumo de materiais e as massas específicas em estado fresco estão apresentados nas Tabela 4.24 a 4.26 . 
Tabela 4.24 - Resumo dos teores de ar obtidos para os traços modificados.

\begin{tabular}{ccccc}
\hline Traço & $\mathrm{C} 25$ 9\% & $\mathrm{C} 2515 \%$ & $\mathrm{C} 40$ 9\% & $\mathrm{C} 4015 \%$ \\
Teor Médio de Ar (\%) & 5,4 & 11,7 & 9,0 & 14,1 \\
\hline
\end{tabular}

Fonte: Elaborada pelo autor.

Tabela 4.25 - Consumo de materiais para concretos com ar incorporado.

\begin{tabular}{ccccc}
\hline \multicolumn{5}{c}{ Consumo de Materiais $\left(\mathbf{k g} / \mathbf{m}^{3}\right)$} \\
\hline \multirow{2}{*}{ Materiais } & $\mathrm{C} 259 \%$ & $\mathrm{C} 25 \quad 15 \%$ & $\mathrm{C} 409 \%$ & $\mathrm{C} 4015 \%$ \\
\cline { 2 - 5 } & 348 & 325 & 333 & 314 \\
\hline Cimento & 0 & 0 & 34 & 32 \\
Súlica ativa & 174 & 163 & 166 & 157 \\
Fíler calcário & 191 & 179 & 150 & 142 \\
Água & 1,391 & 1,299 & 2,629 & 2,479 \\
Superplastificante & 0,696 & 0,650 & 0,333 & 0,628 \\
Incorporador de ar & 281 & 263 & 281 & 265 \\
Areia fina & 422 & 394 & 420 & 396 \\
Areia média & 826 & 771 & 823 & 776 \\
Brita & & & &
\end{tabular}

Fonte: Elaborada pelo autor.

Tabela 4.26 - Massa específica dos concretos em estado fresco.

\begin{tabular}{ccccc}
\hline Traço & $\mathrm{C} 25$ 9\% & $\mathrm{C} 25$ 15\% & $\mathrm{C} 40$ 9\% & $\mathrm{C} 4015 \%$ \\
Massa específica $\left(\mathbf{k g} / \mathbf{m}^{3}\right)$ & 2260 & 2110 & 2227 & 2102 \\
\hline
\end{tabular}

Fonte: Elaborada pelo autor.

\subsubsection{Propriedades do concreto em estado endurecido para traços com ar incorporado}

Após caracterização em estado fresco, os concretos produzidos foram ensaiados em estado endurecido de acordo com as idades propostas inicialmente. Na sequência estão apresentados os resultados da caraterização em estado endurecido para os concretos com ar incorporado. Essa apresentação está feita inicialmente por meio de tabelas com os comentários pertinentes, seguidas por gráficos que comparam os parâmetros determinados. 
- Concreto $\mathrm{C} 25$ 9\%:

Tabela 4.27 - C25 9\% - Resultados de resistência à compressão.

\begin{tabular}{cccccccc}
\hline \multicolumn{7}{c}{ Resistência à Compressão (MPa) } \\
\hline \multirow{2}{*}{ CP } & 12 horas & 15 horas & 18 horas & 21 horas & 24 horas & 7 dias & 28 dias \\
\cline { 2 - 8 } & 2,32 & 2,98 & 3,68 & 4,60 & 5,30 & 16,94 & 25,47 \\
\hline 1 & 1,99 & 2,52 & 3,28 & 4,32 & 4,94 & 16,18 & $28,15^{*}$ \\
2 & 1,15 & 1,75 & 3,01 & 3,90 & 5,59 & 17,55 & 25,46 \\
3 & - & - & - & - & - & - & 25,87 \\
4 & - & - & - & - & - & - & 25,08 \\
5 & 1,82 & 2,42 & 3,32 & 4,27 & 5,27 & 16,89 & 25,47 \\
Média & 0,60 & 0,62 & 0,33 & 0,35 & 0,33 & 0,69 & 0,32 \\
Desvio Padrão & 33,12 & 25,71 & 10,05 & 8,29 & 6,16 & 4,00 & 1,30 \\
CV (\%) & & & & & & &
\end{tabular}

Nota:

* Valor de resistência descartado pelo critério de Chauvenet, conforme apresentado em apêndice. Sendo assim, esse valor não foi utilizado para se determinar a média, o desvio padrão e o coeficiente de variação.

Fonte: Elaborada pelo autor.

Figura 4.8 - C25 9\% - Evolução da resistência à compressão (valores médios) com o tempo.

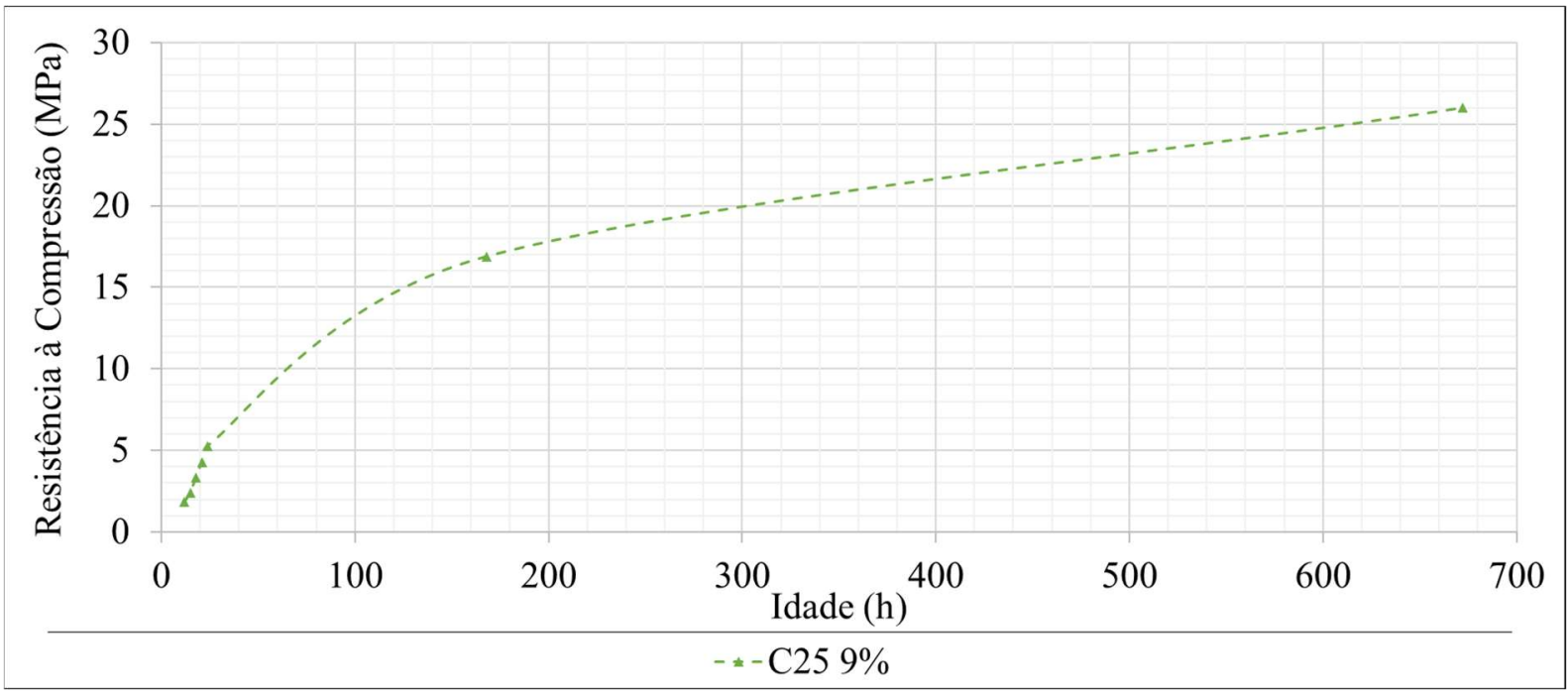

Fonte: Elaborada pelo autor.

A resistência à compressão média observada aos 28 dias define, para desvio padrão de 4,0 MPa, um $f_{c k}$ de valor 18,9 MPa (ABNT, 2015b). Esse valor faz com que o concreto $\mathrm{C} 25$ 9\% não possa ser considerado com função estrutural (ABNT, 2014a).

Observa-se uma queda de cerca de $41 \%$ em relação a resistência à compressão média aos 28 dias do concreto de referência (43,3 MPa). Segundo Kosmatka, Kerkhoff e 
Panarese (2002), a resistência à compressão tende a ser reduzida de $2 \%$ a $6 \%$ a cada aumento de $1 \%$ no teor de ar incorporado. Isso significa que, para um teor de 5,4\% a queda máxima observada deveria ser de aproximadamente $29 \%$, valor bem abaixo do obtido com os ensaios.

Com 1 dia, a resistência à compressão observada foi de 20,7\% da resistência obtida com 28 dias. Aos 7 dias, esse valor subiu para 66,3\%. Mais uma vez, os resultados ficaram abaixo, mas próximos, da previsão de 23\% e 74\% apresentadas em Battagin (2001).

Para as idades iniciais, tem-se que o valor mínimo de $3 \mathrm{MPa}$ é atingido apenas após 18 horas. Ainda assim, o valor de 1,82 MPa obtido com 12 horas já seria suficiente para desforma das paredes de concreto, conforme Sacht e Rossignolo (2008).

Tabela 4.28 - C28 9\% - Resultados de resistência à tração por compressão diametral e na flexão aos 28 dias.

\begin{tabular}{ccc}
\hline \multicolumn{3}{c}{ Resistência à Tração aos 28 dias (MPa) } \\
\hline CP & Compressão Diametral & Flexão \\
\hline 1 & 2,76 & 4,21 \\
2 & 2,41 & 4,40 \\
3 & 3,00 & 4,27 \\
Média & 2,72 & 4,29 \\
Desvio Padrão & 0,30 & 0,10 \\
CV (\%) & 10,80 & 2,30 \\
\hline \multicolumn{3}{c}{}
\end{tabular}

Em termos de resistência à tração, $f_{c t m, s p}$ apresenta valor de cerca de $63 \%$ de $f_{c t m, f}$. Portanto, a relação encontrada ficou abaixo dos 78\% indicados pela NBR 6118:2014 (ABNT, 2014a).

A queda de resistência média à tração na flexão em comparação com o concreto de referência foi de 16\%. Kosmatka, Kerkhoff e Panarese (2002) afirmam que a cada 1\% de aumento no teor de ar incorporado, é observada uma redução de aproximadamente $2 \%$ a $4 \%$ da resistência à flexão. Sendo assim, para um teor de 5,4\% de ar incorporado, a queda observada deveria ser de $10,3 \%$ a $19,8 \%$. Portanto, o valor obtido experimentalmente se enquadra no intervalo proposto.

Conforme Tabela 4.11, tem-se que, para resistência média à compressão de 25,5 $\mathrm{MPa}$, a resistência à tração deve ser da ordem de 2,0 $\mathrm{MPa}$. A resistência à tração média $\left(f_{c t, m}\right)$ é de 2,45 MPa com base no valor de $f_{c t m, s p}$ e de 3,00 MPa com base em $f_{c t m, f}$ (ABNT, 2014a). 
Tabela 4.29 - C25 9\% - Resultados dos ensaios dinâmicos.

\begin{tabular}{ccccccccc}
\hline \multirow{2}{*}{ Parâmetros } & \multicolumn{7}{c}{ Idade } \\
\cline { 2 - 8 } & 12 horas & 15 horas & 18 horas & 21 horas & 24 horas & 7 dias & 28 dias \\
\hline \multirow{2}{*}{$\boldsymbol{E}_{\boldsymbol{F}}$} & Média & 9,32 & 11,16 & 13,19 & 15,10 & 16,15 & 27,76 & 31,57 \\
$(\mathbf{G P a})$ & Desvio Padrão & 2,04 & 1,40 & 0,82 & 0,54 & 0,36 & 0,99 & 0,74 \\
& CV (\%) & 21,93 & 12,51 & 6,18 & 3,58 & 2,24 & 3,6 & 2,3 \\
$\boldsymbol{E}_{\boldsymbol{L}}$ & Média & 9,21 & 10,74 & 12,63 & 14,34 & 15,56 & 26,71 & 30,48 \\
$(\mathbf{G P a})$ & Desvio Padrão & 2,39 & 1,72 & 1,07 & 0,64 & 0,34 & 0,35 & 0,64 \\
& CV (\%) & 25,95 & 15,98 & 8,44 & 4,46 & 2,16 & 1,3 & 2,1 \\
$\mathbf{G}$ & Média & 3,81 & 4,62 & 5,44 & 6,10 & 6,57 & 11,14 & 12,81 \\
$(\mathbf{G P a})$ & Desvio Padrão & 0,91 & 0,72 & 0,49 & 0,31 & 0,19 & 0,19 & 0,20 \\
& CV (\%) & 23,82 & 15,59 & 9,09 & 5,11 & 2,85 & 1,8 & 1,6 \\
& Média & 0,23 & 0,26 & 0,21 & 0,23 & 0,23 & 0,24 & 0,25 \\
$\boldsymbol{v}$ & Desvio Padrão & 0,02 & 0,06 & 0,03 & 0,01 & 0,03 & 0,05 & 0,02 \\
& CV (\%) & 6,55 & 24,74 & 12,60 & 4,95 & 10,79 & 19,0 & 6,0 \\
\hline
\end{tabular}

Fonte: Elaborada pelo autor.

Para o $f_{c k}$ de $18,9 \mathrm{MPa}$ encontrado, o concreto C25 9\% pode ser considerado como de baixa resistência. Dessa forma, o módulo de elasticidade dinâmico é aproximadamente $40 \%$ maior que o módulo de elasticidade estático (MEHTA; MONTEIRO, 2014). Sendo assim, o valor do módulo de elasticidade estático aos 28 dias seria equivalente a 18,3 GPa.

No caso dos prismas ensaiados aos 28 dias para o concreto em questão, a densidade era de $2302 \mathrm{~kg} / \mathrm{m}^{3}$. Assim, segundo Equação 4.2, o módulo de elasticidade estático pode ser estimado em 22,1 GPa.

Com análise feita de acordo com NBR 6118:2014 a partir do valor de $f_{c k}$, o valor de $E_{c i}$ é de 29,2 GPa, mais alto que os valores obtidos pelos outros métodos (ABNT, 2014a).

Kosmatka, Kerkhoff e Panarese (2002) indicam uma queda de $720 \mathrm{MPa}$ a $1380 \mathrm{MPa}$ no valor do módulo de elasticidade estático para cada aumento de 1\% no valor do teor de ar incorporado. Portanto, para um teor de ar igual a 5,4\%, o intervalo de redução seria de 3,89 GPa até 7,45 GPa. Quando comparado ao concreto de referência, o módulo de elasticidade estático determinado a partir do valor de $f_{c k}$ apresentou redução de 11,5 GPa, valor acima do intervalo esperado. Caso a mesma análise seja feita para o módulo dinâmico, a diferença entre módulos passa a ser de 7,06 GPa, valor que se enquadra no intervalo proposto.

Em relação ao módulo de cisalhamento estático, o valor obtido conforme NBR 6118:2014 é de 10,3 GPa, cerca de 20\% menor do que o obtido com ensaios dinâmicos (ABNT, 2014a). 
Assim como nos concretos de referência, os valores para coeficiente de Poisson estão acima do esperado.

Tabela 4.30 - C25 9\% - Resultados do ensaio de ultrassom.

\begin{tabular}{|c|c|c|c|c|c|c|c|c|}
\hline \multicolumn{9}{|c|}{ Velocidade do Pulso Ultrassônico (m/s) } \\
\hline \multirow{2}{*}{\multicolumn{2}{|c|}{ Direção }} & \multicolumn{7}{|c|}{ Idade } \\
\hline & & 12 horas & 15 horas & 18 horas & 21 horas & 24 horas & 7 dias & 28 dias \\
\hline \multirow{3}{*}{ Transversal } & Média & 2810,1 & 3053,8 & 3313,9 & 3453,0 & 3565,3 & 4241,5 & 4430,0 \\
\hline & $\begin{array}{l}\text { Desvio } \\
\text { Padrão }\end{array}$ & 245,7 & 118,2 & 100,6 & 53,0 & 50,1 & 51,2 & 78,5 \\
\hline & $\mathrm{CV}(\%)$ & 8,74 & 3,87 & 3,04 & 1,53 & 1,40 & 1,2 & 1,8 \\
\hline \multirow{3}{*}{ Longitudinal } & Média & 2457,6 & 2693,8 & 2934,1 & 3099,6 & 3201,1 & 3946,2 & 4208,9 \\
\hline & $\begin{array}{l}\text { Desvio } \\
\text { Padrão }\end{array}$ & 303,9 & 145,5 & 79,8 & 57,8 & 43,7 & 25,5 & 60,0 \\
\hline & $\mathrm{CV}(\%)$ & 12,36 & 5,40 & 2,72 & 1,87 & 1,37 & 0,6 & 1,4 \\
\hline \multicolumn{2}{|l|}{ Média Geral } & 2633,9 & 2873,8 & 3124,0 & 3276,3 & 3383,2 & 4093,8 & 4319,4 \\
\hline \multicolumn{2}{|c|}{ Desvio Padrão Total } & 326,6 & 224,1 & 211,6 & 186,5 & 189,5 & 154,2 & 131,3 \\
\hline \multicolumn{2}{|l|}{ CV Total (\%) } & 12,40 & 7,80 & 6,77 & 5,69 & 5,60 & 3,8 & 3,0 \\
\hline
\end{tabular}

Nota:

De acordo com teste $\mathrm{t}$, apresentado em apêndice, os valores de velocidades transversal e longitudinal aos 28 dias (única idade para qual o teste foi realizado) possuem diferença significativa. Isso significa que não seria correta uma análise conjunta dos valores. Porém, para efeitos de interpretação mais ampla, foram definidos média geral, desvio padrão total e coeficiente de variação total para as velocidades nas idades de ensaio contemplando as duas direções.

Fonte: Elaborada pelo autor.

Conforme a Tabela 3.11, o concreto é de boa qualidade, dado que as velocidades médias longitudinal e transversal aos 28 dias estão entre 3658 e $4572 \mathrm{~m} / \mathrm{s}$.

Em relação ao concreto de referência, pode-se observar uma queda pequena de $2 \%$ na velocidade transversal média para o $\mathrm{C} 25$ 9\%, com 5,4\% de teor de ar incorporado. No caso da velocidade longitudinal, tem-se uma redução de aproximadamente 5\%. Novamente, as velocidades transversais são maiores do que as longitudinais em todas as idades. 
- Concreto C25 15\%:

Tabela 4.31 - C25 15\% - Resultados de resistência à compressão.

\begin{tabular}{cccccccc}
\hline \multicolumn{7}{c}{ Resistência à Compressão (MPa) } \\
\hline \multirow{7}{*}{ CP } & \multicolumn{7}{c}{ Idade } \\
\cline { 2 - 8 } & 12 horas & 15 horas & 18 horas & 21 horas & 24 horas & 7 dias & 28 dias \\
\hline 1 & 0,70 & 1,42 & 1,98 & 2,78 & 2,95 & 11,93 & 17,32 \\
2 & 0,77 & 0,97 & 1,56 & 2,11 & 2,55 & 13,26 & 17,69 \\
3 & 0,51 & 0,68 & 1,37 & 1,97 & 2,67 & 11,52 & 16,66 \\
4 & - & - & - & - & - & - & 18,88 \\
5 & - & - & - & - & - & - & 18,86 \\
Média & 0,66 & 1,03 & 1,64 & 2,29 & 2,72 & 12,24 & 17,88 \\
Desvio Padrão & 0,13 & 0,37 & 0,31 & 0,44 & 0,20 & 0,91 & 0,97 \\
CV (\%) & 20,02 & 36,31 & 19,01 & 19,16 & 7,42 & 7,40 & 5,40 \\
\hline \multicolumn{7}{c}{ Fonte: Elaborada pelo autor. }
\end{tabular}

Figura 4.9 - C25 15\% - Evolução da resistência à compressão (valores médios) com o tempo.

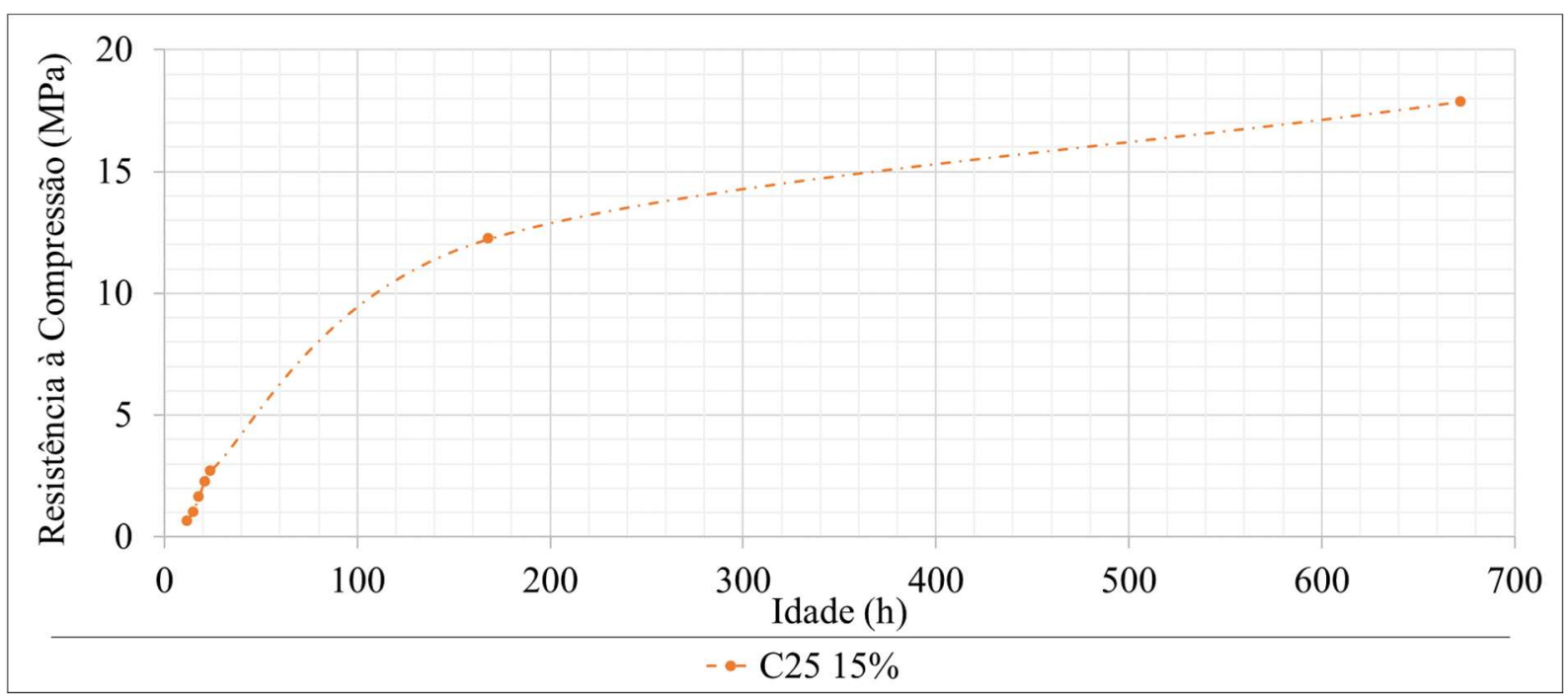

Fonte: Elaborada pelo autor.

A partir dos resultados apresentados pelo concreto C25 9\%, já era esperado que o concreto C25 15\% desenvolvesse baixas resistências. Para desvio padrão de 4,0 MPa, o valor de $f_{c k}$ para o traço em questão é de 11,3 MPa (ABNT, 2015b).

A queda de resistência à compressão média aos 28 dias observada em relação ao concreto de referência é de aproximadamente 59\%. Conforme Tabela 2.3, para um teor de $11,7 \%$ a queda de resistência observada poderia ser de até $51,5 \%$. Portanto, a redução real de resistência à compressão foi maior do que a prevista, apesar de a ordem de grandeza ser parecida. Em comparação com a resistência à compressão média obtida aos 28 dias, observa-se 
valor equivalente a $15,2 \%$ com 1 dia e $68,4 \%$ aos 7 dias. As proporções apresentadas são menores que as de $23 \%$ e $74 \%$ mostradas em Battagin (2001).

Em termos de idades iniciais, os ganhos de resistência são muito baixos, sendo que o valor mínimo proposto ( $3 \mathrm{MPa}$ ) nem chega a ser atingido com 24 horas.

Tabela 4.32 - C25 15\% - Resultados de resistência à tração por compressão diametral e na flexão aos 28 dias.

\begin{tabular}{ccc}
\hline \multicolumn{3}{c}{ Resistência à Tração aos 28 dias (MPa) } \\
\hline CP & Compressão Diametral & Flexão \\
\hline 1 & 1,48 & 3,24 \\
2 & 1,69 & 2,93 \\
3 & 1,72 & 3,52 \\
Média & 1,63 & 3,23 \\
Desvio Padrão & 0,13 & 0,30 \\
CV (\%) & 7,90 & 9,10 \\
\hline
\end{tabular}

Fonte: Elaborada pelo autor.

Para resistências à tração, $f_{c t m, s p}$ representa aproximadamente $50 \%$ de $f_{c t m, f}$, valor inferior aos 78\% definidos pela NBR 6118:2014 (ABNT, 2014a).

A redução no valor da resistência média à tração na flexão quando comparado com o concreto de referência foi de quase $37 \%$. Para um teor de ar incorporado igual a $11,7 \%$, Kosmatka, Kerkhoff e Panarese (2002) indicam uma redução máxima de 38\%. Observa-se como os valores são próximos, o que condiz com a redução teórica esperada.

Conforme Tabela 4.11, a resistência à tração esperada para resistência média à compressão de 17,9 MPa é da ordem de 1,50 MPa. Segundo NBR 6118:2014, a resistência à tração média $\left(f_{c t, m}\right)$ é de $1,47 \mathrm{MPa}$ com base no valor de $f_{c t m, s p}$ e de 2,26 MPa com base em $f_{c t m, f}(\mathrm{ABNT}, 2014 \mathrm{a})$. Tem-se, assim, resultados próximos entre si. 
Tabela 4.33 - C25 15\% - Resultados dos ensaios dinâmicos.

\begin{tabular}{ccccccccc}
\hline \multirow{2}{*}{ Parâmetros } & \multicolumn{7}{c}{ Idade } \\
\cline { 3 - 8 } & 12 horas & 15 horas & 18 horas & 21 horas & 24 horas & 7 dias & 28 dias \\
\hline \multirow{2}{*}{$\boldsymbol{E}_{\boldsymbol{F}}$} & Média & 3,75 & 5,95 & 8,08 & 9,60 & 10,50 & 22,38 & 25,46 \\
$(\mathbf{G P a})$ & Desvio Padrão & 1,19 & 1,39 & 0,61 & 0,50 & 0,45 & 0,65 & 0,75 \\
& CV (\%) & 31,73 & 23,32 & 7,53 & 5,23 & 4,29 & 2,9 & 3,0 \\
$\boldsymbol{E}_{\boldsymbol{L}}$ & Média & 3,72 & 5,83 & 7,90 & 9,42 & 10,30 & 21,47 & 24,57 \\
$\mathbf{( G P a )}$ & Desvio Padrão & 1,31 & 1,56 & 0,69 & 0,66 & 0,55 & 0,57 & 0,60 \\
& CV (\%) & 35,06 & 26,73 & 8,75 & 6,97 & 5,36 & 2,7 & 2,4 \\
$\mathbf{G}$ & Média & 1,55 & 2,43 & 3,36 & 3,93 & 4,33 & 8,93 & 10,25 \\
$(\mathbf{G P a})$ & Desvio Padrão & 0,54 & 0,62 & 0,27 & 0,19 & 0,19 & 0,27 & 0,28 \\
& CV (\%) & 34,77 & 25,53 & 7,95 & 4,87 & 4,49 & 3,0 & 2,7 \\
& Média & 0,20 & 0,23 & 0,21 & 0,24 & 0,22 & 0,26 & 0,23 \\
$\boldsymbol{v}$ & Desvio Padrão & 0,03 & 0,02 & 0,03 & 0,01 & 0,02 & 0,01 & 0,04 \\
& CV (\%) & 15,53 & 7,53 & 11,80 & 4,88 & 9,09 & 3,8 & 17,3 \\
\hline
\end{tabular}

Fonte: Elaborada pelo autor.

Assim como no caso do C25 9\%, o C25 15\% pode ser considerado como de baixa resistência. Portanto, o módulo de elasticidade dinâmico é cerca de $40 \%$ maior que o módulo de elasticidade estático (MEHTA; MONTEIRO, 2014). Isso resulta em um valor de módulo de elasticidade estático aos 28 dias igual a 14,7 GPa.

Os prismas ensaiados aos 28 dias apresentaram densidade média de $2172 \mathrm{~kg} / \mathrm{m}^{3}$, resultando em um módulo de elasticidade estático igual a 17,3 GPa (Equação 4.2).

O valor de $E_{c i}$, com base no valor de $f_{c k}$, é de $22,6 \mathrm{GPa}$, mais alto que os obtidos com os outros dois métodos (ABNT, 2014a).

Conforme visto na Tabela 2.3, a queda do módulo de elasticidade estático a ser observada é de 8,42 GPa até 16,2 GPa, considerando um teor de ar incorporado igual a 11,7\%. Ao se comparar com o concreto de referência, a queda no valor de $E_{c i}$ observada para o traço em questão é de 18,1 GPa, ou seja, além do esperado. Comparando-se os módulos dinâmicos, essa queda seria de 13,1 GPa, dentro do intervalo proposto.

O módulo de cisalhamento estático é de $7,79 \mathrm{GPa}$, cerca de $25 \%$ menor do que o obtido com ensaios dinâmicos (ABNT, 2014a).

Em relação ao coeficiente de Poisson, mais uma vez se observa valores elevados. 
Tabela 4.34 - C25 15\% - Resultados do ensaio de ultrassom.

\begin{tabular}{|c|c|c|c|c|c|c|c|c|}
\hline \multicolumn{9}{|c|}{ Velocidade do Pulso Ultrassônico (m/s) } \\
\hline \multirow{2}{*}{\multicolumn{2}{|c|}{ Direção }} & \multicolumn{7}{|c|}{ Idade } \\
\hline & & $\begin{array}{c}12 \\
\text { horas }\end{array}$ & $\begin{array}{c}15 \\
\text { horas }\end{array}$ & $\begin{array}{c}18 \\
\text { horas }\end{array}$ & $\begin{array}{c}21 \\
\text { horas }\end{array}$ & $\begin{array}{c}24 \\
\text { horas }\end{array}$ & 7 dias & $\begin{array}{c}28 \\
\text { dias }\end{array}$ \\
\hline \multirow{3}{*}{ Transversal } & Média & 1868,7 & 2291,6 & 2794,0 & 2879,4 & 3018,8 & 3975,9 & 4191,2 \\
\hline & $\begin{array}{l}\text { Desvio } \\
\text { Padrão }\end{array}$ & 259,5 & 227,6 & 157,3 & 107,9 & 116,6 & 75,8 & 119,2 \\
\hline & $\mathrm{CV}(\%)$ & 13,89 & 9,93 & 5,63 & 3,75 & 3,86 & 1,9 & 2,8 \\
\hline \multirow{3}{*}{ Longitudinal } & Média & $1506,2^{*}$ & 1987,0 & 2379,4 & 2551,8 & 2670,2 & 3705,0 & 3944,8 \\
\hline & $\begin{array}{l}\text { Desvio } \\
\text { Padrão }\end{array}$ & $144,4^{*}$ & 255,3 & 68,5 & 52,1 & 48,6 & 41,8 & 43,3 \\
\hline & CV $(\%)$ & $9,59 *$ & 12,85 & 2,88 & 2,04 & 1,82 & 1,1 & 1,1 \\
\hline \multicolumn{2}{|l|}{ Média Geral } & 1723,7 & 2139,3 & 2586,7 & 2715,6 & 2844,5 & 3840,5 & 4068,0 \\
\hline \multicolumn{2}{|c|}{ Desvio Padrão Total } & 283,1 & 284,8 & 241,2 & 185,3 & 196,8 & 149,4 & 152,8 \\
\hline \multicolumn{2}{|l|}{ CV Total (\%) } & 16,42 & 13,31 & 9,32 & 6,82 & 6,92 & 3,9 & 3,8 \\
\hline
\end{tabular}

Notas:

De acordo com teste $t$, apresentado em apêndice, os valores de velocidades transversal e longitudinal aos 28 dias (única idade para qual o teste foi realizado) possuem diferença significativa. Isso significa que não seria correta uma análise conjunta dos valores. Porém, para efeitos de interpretação mais ampla, foram definidos média geral, desvio padrão total e coeficiente de variação total para as velocidades nas idades de ensaio contemplando as duas direções.

* Não foram consideradas as velocidades longitudinais em um dos prismas ensaiados. Isso porque percebeu-se tardiamente que esses dados não foram medidos.

Fonte: Elaborada pelo autor.

Segundo a Tabela 3.11 , o concreto C25 15\% pode ser classificado como de boa qualidade. Quando comparado com o concreto de referência, observa-se uma queda de 7\% na velocidade transversal média para o C25 15\%, com 11,7\% de teor de ar incorporado. No caso da velocidade longitudinal, tem-se uma redução de aproximadamente $11 \%$.

Assim como observado para os prismas de todos os concretos analisados até aqui, as velocidades transversais são maiores do que as longitudinais em todas as idades. 
- Concreto $\mathrm{C} 40$ 9\%:

Tabela 4.35 - C40 9\% - Resultados de resistência à compressão.

\begin{tabular}{|c|c|c|c|c|c|c|c|}
\hline \multicolumn{8}{|c|}{ Resistência à Compressão (MPa) } \\
\hline \multirow{2}{*}{$\mathbf{C P}$} & \multicolumn{7}{|c|}{ Idade } \\
\hline & 12 horas & 15 horas & 18 horas & 21 horas & 24 horas & 7 dias & 28 dias \\
\hline 1 & 2,13 & 3,06 & 4,27 & 6,04 & 6,44 & 25,57 & 43,43 \\
\hline 2 & 2,23 & 2,80 & 4,52 & 6,23 & 7,10 & 25,24 & 42,49 \\
\hline 3 & 2,22 & 3,22 & 4,16 & 6,05 & 6,57 & 25,88 & $39,080^{*}$ \\
\hline 4 & - & - & - & - & - & - & 43,60 \\
\hline 5 & - & - & - & - & - & - & 44,31 \\
\hline Média & 2,19 & 3,03 & 4,31 & 6,11 & 6,70 & 25,56 & 43,46 \\
\hline Desvio Padrão & 0,05 & 0,22 & 0,18 & 0,10 & 0,35 & 0,32 & 0,75 \\
\hline CV (\%) & 2,37 & 7,11 & 4,26 & 1,69 & 5,22 & 1,20 & 1,70 \\
\hline
\end{tabular}

Nota:

* Valor de resistência descartado pelo critério de Chauvenet, conforme apresentado em apêndice. Sendo assim, esse valor não foi utilizado para se determinar a média, o desvio padrão e o coeficiente de variação.

Fonte: Elaborada pelo autor.

Figura 4.10 - C40 9\% - Evolução da resistência à compressão (valores médios) com o tempo.

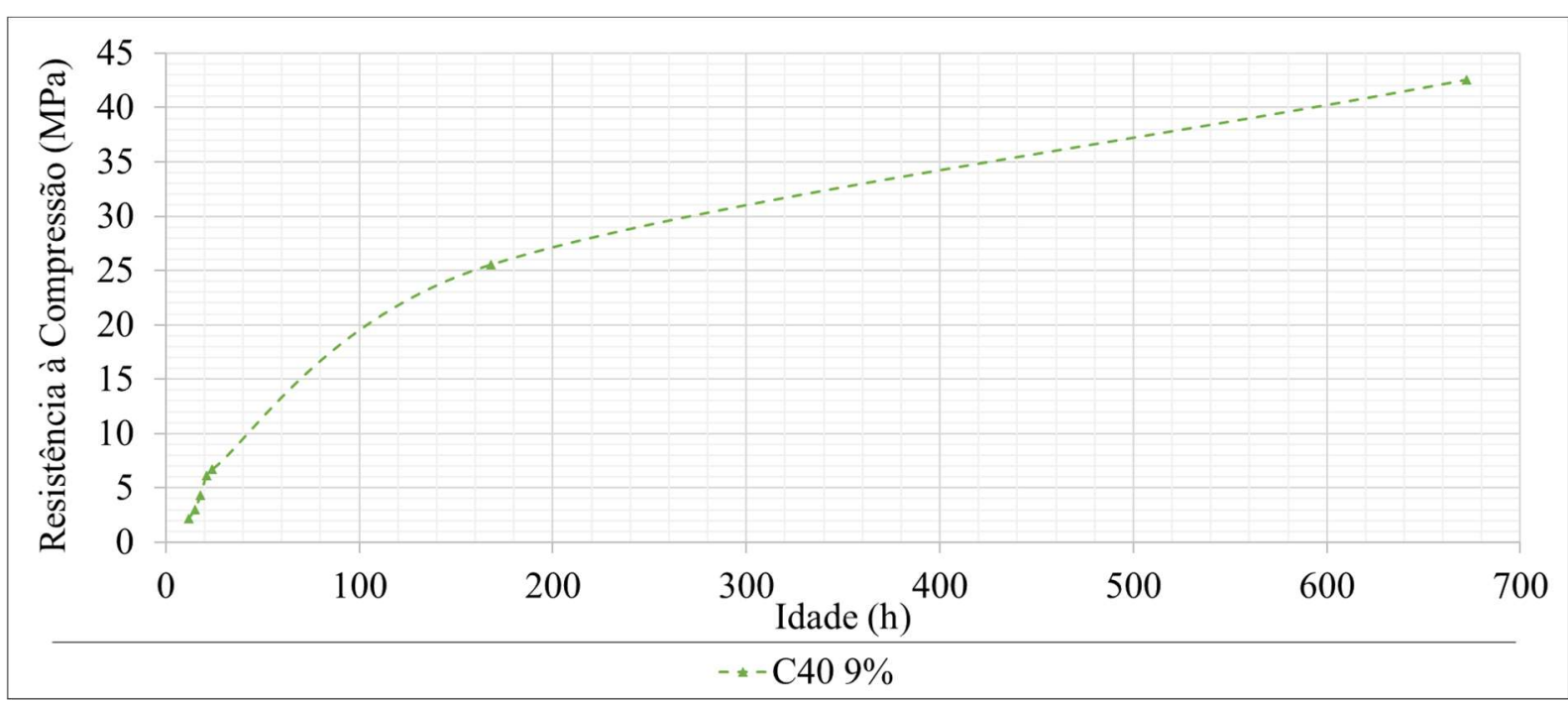

Fonte: Elaborada pelo autor.

Com os resultados obtidos, determina-se o valor de $f_{c k}$ como sendo de $36,9 \mathrm{MPa}$ (ABNT, 2015b). Dessa forma, o concreto C40 9\% apresenta resistência característica mínima para ser considerado como estrutural (ABNT, 2014a). Mais ainda, o valor obtido está próximo ao máximo de $40 \mathrm{MPa}$ determinado pela NBR 16055:2012, tornando-o promissor para utilização em paredes de concreto (ABNT, 2012b). 
A resistência à compressão média obtida aos 28 dias é cerca de $30 \%$ menor do que a observada em relação ao concreto de referência. Para um teor de ar igual a 9\%, esperava-se, conforme Tabela 2.3, que a queda fosse de $16,6 \%$ a 42,7\%. Assim, a redução obtida se encontra no intervalo esperado.

Com 1 dia de idade, a resistência à compressão observada era de 15,4\% da obtida aos 28 dias. No caso de 7 dias, esse valor sobe para 58,8\% em comparação aos mesmos 28 dias. Novamente, os valores de $23 \%$ e $74 \%$ previstos em Battagin (2001) não se adequam muito bem ao concreto em questão.

Para as idades iniciais, o concreto apresentou bons resultados, atingindo o valor de 3,0 MPa com 15 horas.

Tabela 4.36 - C40 9\% - Resultados de resistência à tração por compressão diametral e na flexão aos 28 dias.

\begin{tabular}{ccc}
\hline \multicolumn{3}{c}{ Resistência à Tração aos 28 dias $(\mathrm{MPa})$} \\
\hline $\mathrm{CP}$ & Compressão Diametral & Flexão \\
\hline 1 & 2,83 & 5,19 \\
2 & 3,96 & 5,72 \\
3 & 2,47 & 6,09 \\
Média & 3,09 & 5,66 \\
Desvio Padrão & 0,78 & 0,45 \\
CV (\%) & 25,30 & 8,00 \\
\hline
\end{tabular}

Como observado na Tabela $4.34, f_{c t m, s p}$ equivale a aproximadamente $55 \%$ de $f_{c t m, f}$, valor menor que 78\% (ABNT, 2014a).

A redução observada para a resistência média à tração na flexão em comparação com o concreto C40 de referência é de 28,3\%. Segundo Tabela 2.3, para um teor de ar incorporado igual a $9 \%$, a redução deveria ser de $16,6 \%$ até $30,7 \%$. Portanto, a queda observada respeita a consideração teórica.

A Tabela 4.11 indica que a resistência à tração esperada para resistência média à compressão de 43,5 MPa é da ordem de 3,30 MPa. A resistência à tração média $\left(f_{c t, m}\right)$ é de 2,78 MPa com base no valor de $f_{c t m, s p}$ e de 3,96 MPa com base em $f_{c t m, f}$ (ABNT, 2014a). 
Tabela 4.37 - C40 9\% - Resultados dos ensaios dinâmicos.

\begin{tabular}{ccccccccc}
\hline \multirow{2}{*}{ Parâmetros } & \multicolumn{7}{c}{ Idade } \\
\cline { 2 - 9 } & 12 horas & 15 horas & 18 horas & 21 horas & 24 horas & 7 dias* & 28 dias \\
\hline \multirow{2}{*}{$\boldsymbol{E}_{\boldsymbol{F}}$} & Média & 9,58 & 11,62 & 13,86 & 15,96 & 17,21 & 29,12 & 32,88 \\
$(\mathbf{G P a})$ & Desvio Padrão & 0,15 & 0,20 & 0,34 & 0,37 & 0,41 & 0,11 & 0,57 \\
& CV (\%) & 1,57 & 1,76 & 2,43 & 2,34 & 2,37 & 0,4 & 1,7 \\
$\boldsymbol{E}_{\boldsymbol{L}}$ & Média & 9,38 & 11,44 & 13,50 & 15,71 & 16,68 & 28,59 & 31,80 \\
$(\mathbf{G P a})$ & Desvio Padrão & 0,45 & 0,30 & 0,23 & 0,05 & 0,19 & - & 0,24 \\
& CV (\%) & 4,80 & 2,64 & 1,70 & 0,34 & 1,15 & - & 0,8 \\
$\mathbf{G}$ & Média & 3,89 & 4,87 & 5,67 & 6,45 & 7,01 & 12,15 & 13,46 \\
$(\mathbf{G P a})$ & Desvio Padrão & 0,04 & 0,12 & 0,08 & 0,06 & 0,03 & - & 0,03 \\
& CV (\%) & 1,07 & 2,49 & 1,32 & 0,97 & 0,44 & - & 0,2 \\
& Média & 0,24 & 0,21 & 0,23 & 0,26 & 0,25 & 0,20 & 0,22 \\
$\boldsymbol{V}$ & Desvio Padrão & 0,03 & 0,06 & 0,04 & 0,04 & 0,05 & - & 0,03 \\
& CV (\%) & 10,63 & 26,51 & 17,83 & 13,68 & 18,28 & - & 15,7 \\
\hline
\end{tabular}

Notas:

* Os dados apresentados são referentes a apenas 1 prisma. Isso porque percebeu-se tardiamente que 2 prismas não foram ensaiados na idade correta. $\mathrm{O}$ traço em questão foi concretado em dois dias diferentes por problemas relacionados ao espalhamento obtido em uma das betonadas no primeiro dia. Dessa forma, 2 dos 3 prismas foram ensaiados em datas diferentes dos demais corpos de prova.

$$
\text { Fonte: Elaborada pelo autor. }
$$

O concreto C40 9\% pode ser considerado de média resistência. Dessa forma, o módulo de elasticidade estático aos 28 dias tem valor estimado igual a 22,3 GPa (MEHTA; MONTEIRO, 2014).

Considerando ensaio aos 28 dias, os prismas do C40 9\% apresentaram densidade média de $2240 \mathrm{~kg} / \mathrm{m}^{3}$. Portanto, segundo Equação 4.2, o módulo de elasticidade estático é de 24,1 GPa.

A partir do valor de $f_{c k}$, define-se $E_{c i}$ com valor de 40,8 GPa (ABNT, 2014a). Kerkhoff, Kosmatka e Panarese (2002) indicam que a queda do módulo de elasticidade estático em relação ao obtido para o traço de referência deve respeitar o intervalo de 6,48 até 12,4 GPa, considerando um teor de ar incorporado igual a 9\%. No caso dessa comparação, a queda foi de 8,17 GPa para o valor de $E_{c i}$. Quando essa análise é feita para o módulo dinâmico, a queda passa a ser de $14,6 \mathrm{GPa}$, valor superior ao intervalo proposto.

O módulo de cisalhamento estático determinado conforme NBR 6118:2014 é de 15,2 GPa, cerca de 13\% maior do que o obtido com ensaios dinâmicos (ABNT, 2014a).

Os valores obtidos para o coeficiente de Poisson em todas as idades ficaram acima do valor de 0,20, com exceção da idade de 7 dias, que apresentou valor igual a 0,20. 
Tabela 4.38 - C40 9\% - Resultados do ensaio de ultrassom.

\begin{tabular}{|c|c|c|c|c|c|c|c|c|}
\hline \multicolumn{9}{|c|}{ Velocidade do Pulso Ultrassônico (m/s) } \\
\hline \multirow{2}{*}{\multicolumn{2}{|c|}{ Direção }} & \multicolumn{7}{|c|}{ Idade } \\
\hline & & 12 horas & 15 horas & 18 horas & 21 horas & 24 horas & 7 dias* & 28 dias \\
\hline \multirow{3}{*}{ Transversal } & Média & 3165,7 & 3322,0 & 3556,2 & 3651,6 & 3742,0 & 4312,8 & 4607,7 \\
\hline & $\begin{array}{l}\text { Desvio } \\
\text { Padrão }\end{array}$ & 216,9 & 143,2 & 165,7 & 131,8 & 129,8 & 20,1 & 46,5 \\
\hline & $\mathrm{CV}(\%)$ & 6,85 & 4,31 & 4,66 & 3,61 & 3,47 & 0,5 & 1,0 \\
\hline \multirow{3}{*}{ Longitudinal } & Média & 2848,0 & 3004,4 & 3324,2 & 3360,9 & 3437,0 & 4063,7 & 4346,0 \\
\hline & $\begin{array}{l}\text { Desvio } \\
\text { Padrão }\end{array}$ & 206,1 & 122,5 & 278,1 & 108,7 & 91,8 & 9,9 & 47,3 \\
\hline & $\mathrm{CV}(\%)$ & 7,24 & 4,08 & 8,37 & 3,23 & 2,67 & 0,2 & 1,1 \\
\hline \multicolumn{2}{|l|}{ Média Geral } & 3006,9 & 3163,2 & 3440,2 & 3506,3 & 3589,5 & 4188,3 & 4476,8 \\
\hline \multicolumn{2}{|c|}{ Desvio Padrão Total } & 263,9 & 207,6 & 255,4 & 189,3 & 190,0 & 128,7 & 139,9 \\
\hline \multicolumn{2}{|l|}{ CV Total (\%) } & 8,78 & 6,56 & 7,42 & 5,40 & 5,29 & 3,1 & 3,1 \\
\hline
\end{tabular}

Notas:

De acordo com teste t, apresentado em apêndice, os valores de velocidades transversal e longitudinal aos 28 dias (única idade para qual o teste foi realizado) possuem diferença significativa. Isso significa que não seria correta uma análise conjunta dos valores. Porém, para efeitos de interpretação mais ampla, foram definidos média geral, desvio padrão total e coeficiente de variação total para as velocidades nas idades de ensaio contemplando as duas direções.

* Os dados apresentados são referentes a apenas 1 prisma. Isso porque percebeu-se tardiamente que 2 prismas não foram ensaiados na idade correta. $O$ traço em questão foi concretado em dois dias diferentes por problemas relacionados ao espalhamento obtido em uma das betonadas no primeiro dia. Dessa forma, 2 dos 3 prismas foram ensaiados em datas diferentes dos demais corpos de prova.

Fonte: Elaborada pelo autor.

Assim como indicado na Tabela 3.11, a velocidade média identificada aos 28 dias para a direção transversal caracteriza o concreto como de excelente qualidade. No caso da velocidade média para a direção longitudinal, o concreto fica caracterizado com boa qualidade. Essa diferença se dá pelo fato de os valores médios estarem próximos ao limite de $4572 \mathrm{~m} / \mathrm{s}$ que define uma ou outra classe de qualidade.

Quando comparado ao concreto de referência, o C40 9\% apresenta redução de 2,6\% na velocidade média transversal e redução de $7,4 \%$ no caso da velocidade média longitudinal. Outra vez, as velocidades transversais são maiores do que as longitudinais em todas as idades. 
- Concreto C40 15\%:

Tabela 4.39 - C40 15\% - Resultados de resistência à compressão.

\begin{tabular}{cccccccc}
\hline \multicolumn{7}{c}{ Resistência à Compressão (MPa) } \\
\hline \multirow{7}{*}{ CP } & \multicolumn{7}{c}{ Idade } \\
\cline { 2 - 8 } & 12 horas & 15 horas & 18 horas & 21 horas & 24 horas & 7 dias & 28 dias \\
\hline 1 & 3,31 & 4,88 & 5,92 & 7,09 & 7,89 & 22,20 & 34,19 \\
2 & 3,14 & 3,87 & 5,07 & 6,92 & 7,71 & 24,85 & 36,34 \\
3 & 2,55 & 3,49 & 4,97 & 6,62 & 7,17 & 23,64 & 31,64 \\
4 & - & - & - & - & - & - & 34,42 \\
5 & - & - & - & - & - & - & 32,91 \\
Média & 3,00 & 4,08 & 5,32 & 6,88 & 7,59 & 23,56 & 33,90 \\
Desvio Padrão & 0,40 & 0,72 & 0,52 & 0,24 & 0,37 & 1,33 & 1,76 \\
CV (\%) & 13,34 & 17,67 & 9,80 & 3,45 & 4,92 & 5,60 & 5,20 \\
\hline
\end{tabular}

Fonte: Elaborada pelo autor.

Figura 4.11 - C40 15\% - Evolução da resistência à compressão (valores médios) com o tempo.

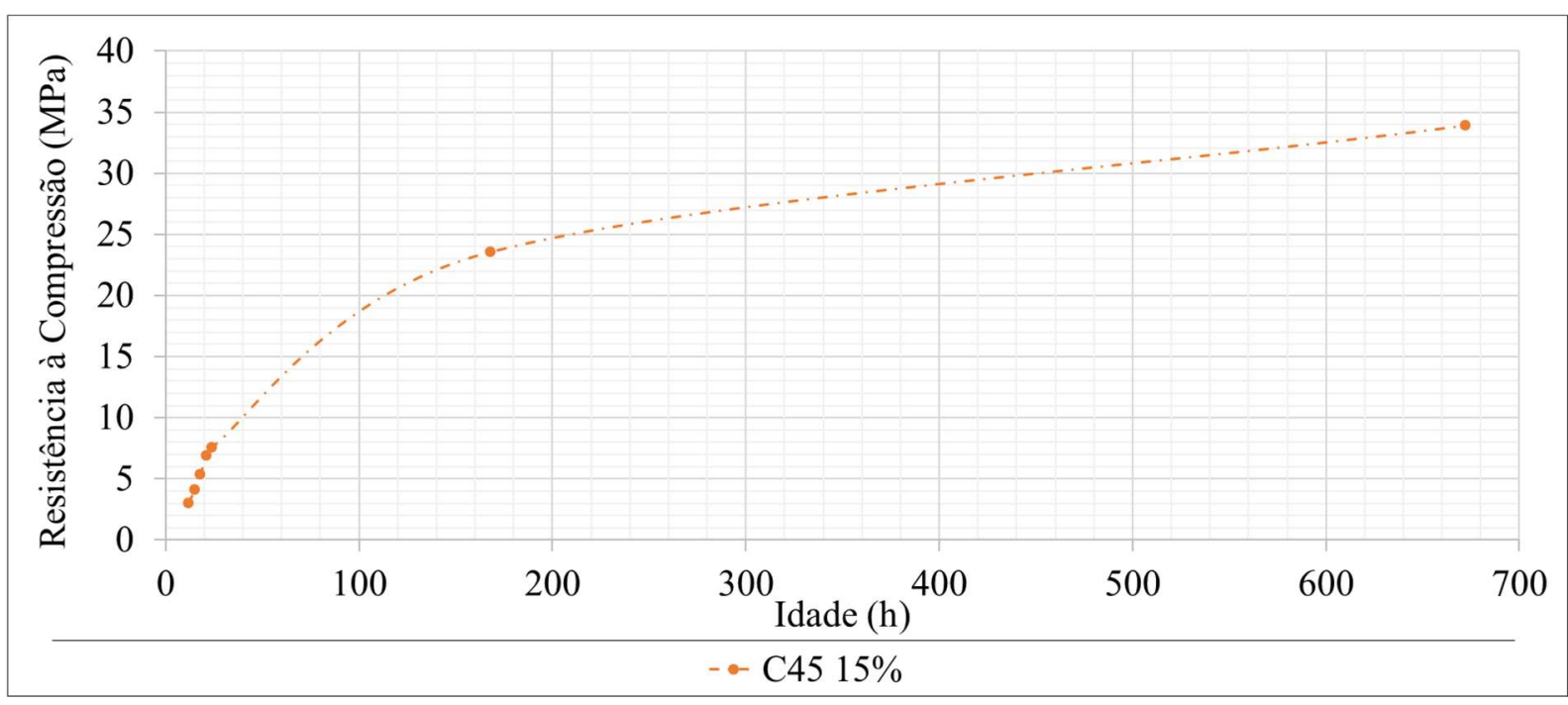

Fonte: Elaborada pelo autor.

Os resultados obtidos permitem a definição do valor de $f_{c k}$ para o C40 15\% como sendo de 27,3 MPa (ABNT, 2015b). Dessa maneira, em termos de resistência à compressão, o traço proposto pode ser considerado como concreto estrutural (ABNT, 2014a). O valor obtido é muito próximo à resistência mínima de $25 \mathrm{MPa}$, fazendo com que esse concreto também seja promissor para a construção de paredes de concreto (ABNT, 2012b).

Observou-se queda de resistência à compressão média aos 28 dias de 45,7\% em relação ao C40 de referência. Segundo Tabela 2.3, para um teor de $14,1 \%$ a queda de resistência 
observada deve respeitar o intervalo de $24,8 \%$ até $58,2 \%$, o que acontece com o concreto analisado.

A resistência à compressão obtida com 1 dia foi 22,4\% daquela observada aos 28 dias. Quando a comparação é feita de 7 para 28 dias, esse valor foi de 69,5\%. Abaixo da expectativa apresentada por Battagin (2001).

As resistências iniciais apresentaram valores elevados, sendo que em 12 horas, o valor mínimo de 3,0 MPa já foi alcançado, resultado que não foi obtido nem para o concreto de referência.

Tabela 4.40 - C40 15\% - Resultados de resistências à tração por compressão diametral e na flexão aos 28 dias.

\begin{tabular}{ccc}
\hline \multicolumn{3}{c}{ Resistência à Tração aos 28 dias (MPa) } \\
\hline CP & Compressão Diametral & Flexão \\
\hline 1 & 2,39 & 5,31 \\
2 & 2,27 & 4,74 \\
3 & 2,25 & 5,05 \\
Média & 2,30 & 5,03 \\
Desvio Padrão & 0,07 & 0,28 \\
CV $(\%)$ & 3,20 & 5,60 \\
\hline
\end{tabular}

Fonte: Elaborada pelo autor.

Com os valores indicados, tem-se que $f_{c t m, s p}$ equivale a aproximadamente $46 \%$ de $f_{c t m, f}$, bem abaixo de 78\% (ABNT, 2014a).

Conforme Tabela 2.3, para um teor de ar incorporado igual a 14,1\%, a redução da resistência média à tração na flexão em comparação com o concreto $\mathrm{C} 40$ de referência deveria ser de $24,8 \%$ até $43,8 \%$. A redução observada é de $36,2 \%$, portanto, a queda observada respeita a consideração teórica.

Segundo Tabela 4.11, a resistência à tração esperada é de aproximadamente 3,0 MPa. A resistência à tração média $\left(f_{c t, m}\right)$ é de 2,07 MPa com base no valor de $f_{c t m, s p}$ e de 3,52 MPa com base em $f_{c t m, f}$ (ABNT, 2014a). 
Tabela 4.41 - C40 15\% - Resultados dos ensaios dinâmicos.

\begin{tabular}{ccccccccc}
\hline \multirow{2}{*}{ Parâmetros } & \multicolumn{7}{c}{ Idade } \\
\cline { 3 - 8 } & 12 horas & 15 horas & 18 horas & 21 horas & 24 horas & 7 dias & 28 dias \\
\hline \multirow{2}{*}{$\boldsymbol{E}_{\boldsymbol{F}}$} & Média & 13,22 & 14,88 & 15,66 & 16,94 & 17,87 & 28,53 & 30,44 \\
$(\mathbf{G P a})$ & Desvio Padrão & 1,08 & 0,98 & 0,77 & 0,78 & 1,06 & 0,99 & 1,24 \\
& CV (\%) & 8,17 & 6,57 & 4,90 & 4,60 & 5,93 & 3,5 & 4,1 \\
$\boldsymbol{E}_{\boldsymbol{L}}$ & Média & 12,72 & 14,37 & 14,93 & 16,33 & 17,05 & 27,80 & 28,93 \\
$(\mathbf{G P a})$ & Desvio Padrão & 1,57 & 0,72 & 0,81 & 0,50 & 0,62 & 1,76 & 1,10 \\
& CV (\%) & 12,31 & 5,04 & 5,45 & 3,03 & 3,66 & 6,3 & 3,8 \\
$\mathbf{G}$ & Média & 5,38 & 6,04 & 6,34 & 6,92 & 7,26 & 11,35 & 12,38 \\
$(\mathbf{G P a})$ & Desvio Padrão & 0,44 & 0,39 & 0,31 & 0,30 & 0,32 & 0,40 & 0,49 \\
& CV (\%) & 8,08 & 6,45 & 4,83 & 4,34 & 4,38 & 3,5 & 4,0 \\
& Média & 0,25 & 0,24 & 0,22 & 0,23 & 0,24 & 0,26 & 0,25 \\
$\boldsymbol{v}$ & Desvio Padrão & 0,03 & 0,03 & 0,03 & 0,03 & 0,03 & 0,01 & 0,01 \\
& CV (\%) & 10,20 & 11,02 & 12,03 & 13,78 & 10,34 & 3,8 & 4,0 \\
\hline
\end{tabular}

Fonte: Elaborada pelo autor.

O concreto C40 15\% pode ser considerado de média resistência (MEHTA; MONTEIRO, 2014). Com essa consideração, o módulo de elasticidade estático aos 28 dias apresenta valor estimado igual a 20,3 GPa.

Os prismas ensaiados aos 28 dias para o concreto C40 15\% resultaram em densidade média de $2175 \mathrm{~kg} / \mathrm{m}^{3}$. Sendo assim, o módulo de elasticidade estático pode ser estimado em 21,8 GPa (Equação 4.2).

A partir do valor de $f_{c k}$, define-se $E_{c i}$ com valor de 35,1 GPa (ABNT, 2014a). Segundo Tabela 2.3, para um teor de ar incorporado de $14,1 \%$, a redução do módulo de elasticidade estático deve estar entre 10,2 GPa e 19,5 GPa em relação ao obtido para o traço de referência. Nessa comparação, a queda foi de 13,9 GPa para os valores de $E_{c i}$, dentro do intervalo esperado. Com a mesma análise sendo realizada para o módulo dinâmico, a queda observada em relação ao concreto de referência é de 17,1 GPa.

O módulo de cisalhamento estático é de 12,7 GPa, valor próximo ao obtido com ensaios dinâmicos (ABNT, 2014a).

Os valores obtidos para o coeficiente de Poisson em todas as idades ficaram acima de 0,20 . 
Tabela 4.42 - C40 15\% - Resultados do ensaio de ultrassom.

\begin{tabular}{|c|c|c|c|c|c|c|c|c|}
\hline \multicolumn{9}{|c|}{ Velocidade do Pulso Ultrassônico (m/s) } \\
\hline \multirow{2}{*}{\multicolumn{2}{|c|}{ Direção }} & \multicolumn{7}{|c|}{ Idade } \\
\hline & & 12 horas & 15 horas & 18 horas & 21 horas & 24 horas & 7 dias & 28 dias \\
\hline \multirow{3}{*}{ Transversal } & Média & 3125,7 & 3306,4 & 3352,8 & 3484,9 & 3556,1 & 4272,1 & 4410,1 \\
\hline & $\begin{array}{l}\text { Desvio } \\
\text { Padrão }\end{array}$ & 79,9 & 63,7 & 48,1 & 40,3 & 27,7 & 51,0 & 51,2 \\
\hline & $\mathrm{CV}(\%)$ & 2,56 & 1,93 & 1,43 & 1,16 & 0,78 & 1,2 & 1,2 \\
\hline \multirow{3}{*}{ Longitudinal } & Média & 2719,1 & 3036,9 & 3116,9 & 3229,6 & 3287,8 & 4015,3 & 4138,7 \\
\hline & $\begin{array}{l}\text { Desvio } \\
\text { Padrão }\end{array}$ & 227,3 & 58,1 & 69,7 & 58,9 & 36,9 & 18,5 & 25,2 \\
\hline & $\mathrm{CV}(\%)$ & 8,36 & 1,91 & 2,24 & 1,82 & 1,12 & 0,5 & 0,6 \\
\hline \multicolumn{2}{|l|}{ Média Geral } & 2922,4 & 3171,7 & 3234,8 & 3357,3 & 3422,0 & 4143,7 & 4274,4 \\
\hline \multicolumn{2}{|c|}{ Desvio Padrão Total } & 265,6 & 148,8 & 132,9 & 138,1 & 139,1 & 135,0 & 142,6 \\
\hline \multicolumn{2}{|l|}{ CV Total (\%) } & 9,09 & 4,69 & 4,11 & 4,11 & 4,06 & 3,3 & 3,3 \\
\hline
\end{tabular}

Notas:

De acordo com teste t, apresentado em apêndice, os valores de velocidades transversal e longitudinal aos 28 dias (única idade para qual o teste foi realizado) possuem diferença significativa. Isso significa que não seria correta uma análise conjunta dos valores. Porém, para efeitos de interpretação mais ampla, foram definidos média geral, desvio padrão total e coeficiente de variação total para as velocidades nas idades de ensaio contemplando as duas direções.

$$
\text { Fonte: Elaborada pelo autor. }
$$

Conforme Tabela 3.11, as velocidades médias identificadas aos 28 dias para as direções transversal e longitudinal caracterizam o concreto como sendo de boa qualidade.

A redução da velocidade transversal observada no C40 15\% em relação ao concreto de referência é de aproximadamente 7\%, enquanto que na direção longitudinal essa queda foi de praticamente 12\%. Novamente, as velocidades transversais são maiores do que as longitudinais em todas as idades.

\subsection{Gráficos comparativos de propriedades dos concretos produzidos}

Neste item estão apresentados gráficos que correlacionam os parâmetros de maior interesse para todos os traços. Vale a observação de que o tempo foi considerado em horas, de maneira a facilitar a apresentação dos resultados das primeiras idades. Dessa forma, a idade de 7 dias é representada por 168 horas, e a idade de 28 dias, por 672 horas. 
- Resistência à compressão:

Figura 4.12 - Concretos da classe C25 - Evolução da resistência à compressão.

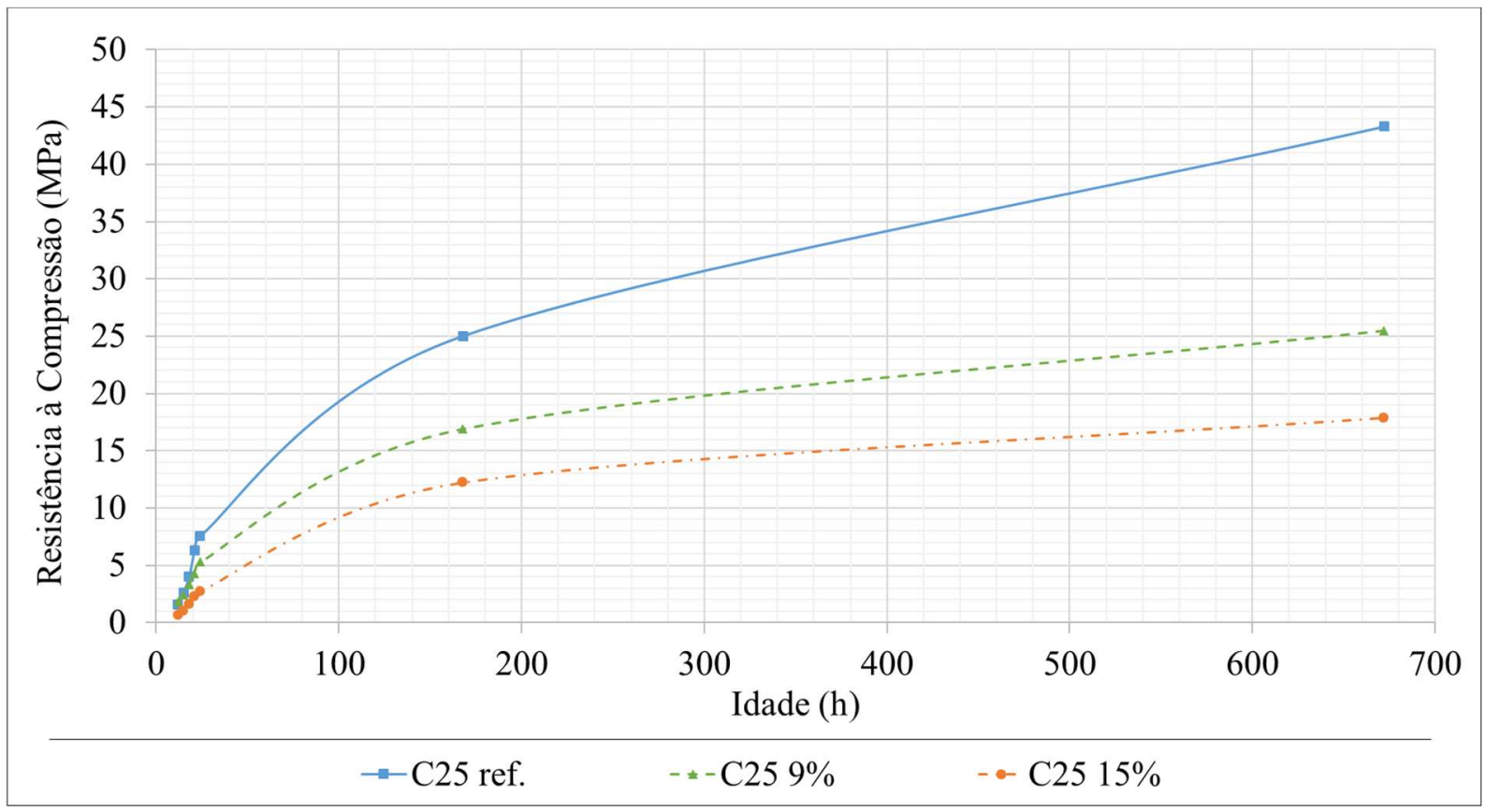

Fonte: Elaborada pelo autor.

Figura 4.13 - Concretos da classe C40 - Evolução da resistência à compressão.

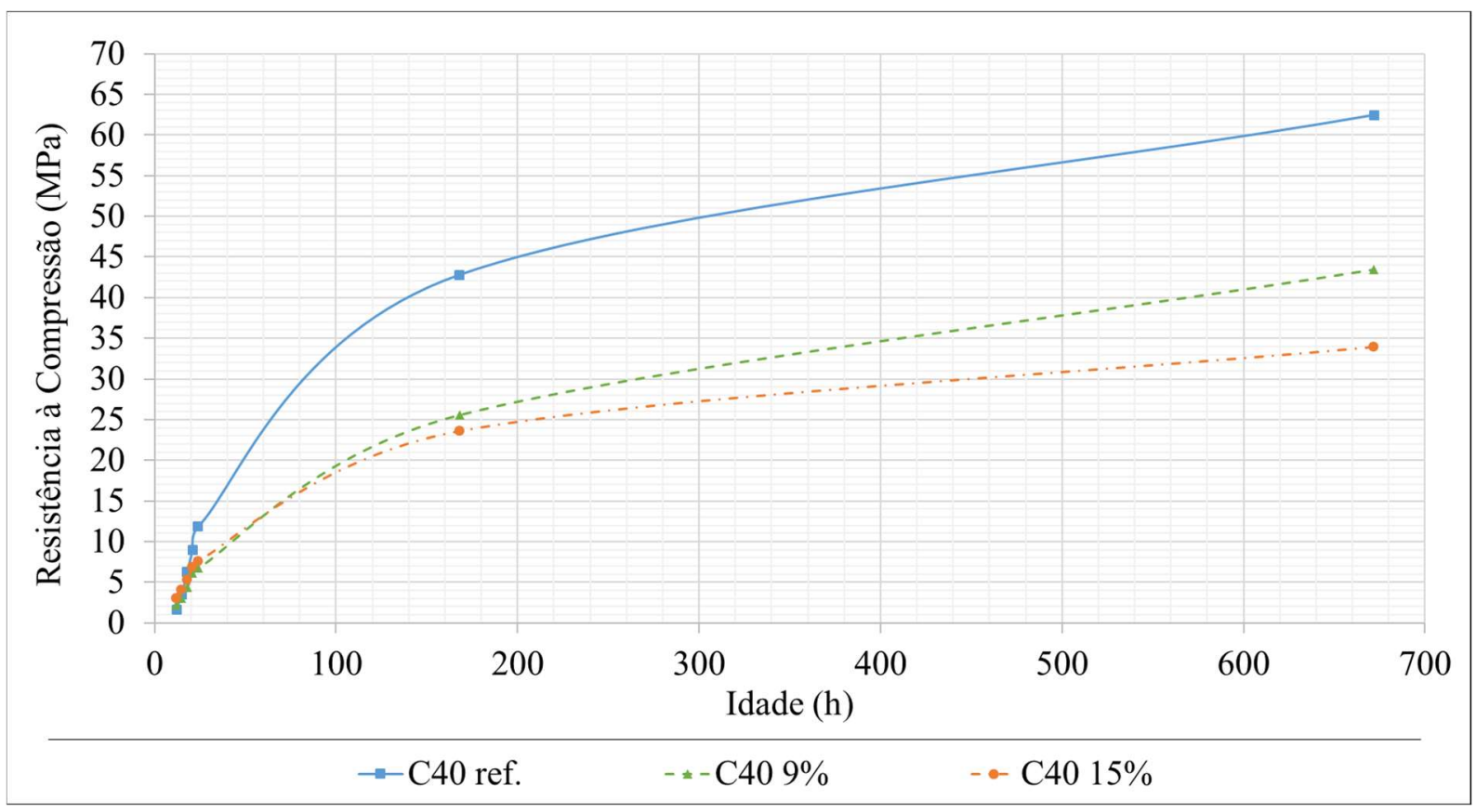

Fonte: Elaborada pelo autor.

Com os resultados plotados em gráficos, percebe-se claramente as quedas de resistências decorrentes da incorporação de ar, conforme apresentado nas análises anteriores. 
Chama a atenção, ainda, o fato de as resistências à compressão para as primeiras idades nos traços de classe C40 estarem muito próximas, indicando a pequena variação de resultados observada.

- Módulo de elasticidade dinâmico:

A partir das Figuras 4.14 e 4.15, percebe-se que a inclinação das curvas varia muito pouco entre os concretos de mesma classe de resistência. É possível observar também a tendência de estabilização dos resultados. No caso das primeiras idades, os resultados mostram quase que uma sobreposição das curvas para os concretos com ar incorporado (classe C40), sendo que somente após os 7 dias o concreto C40 9\% se distancia um pouco do C40 15\%. Isso indica que o aumento de $9 \%$ para $14,1 \%$ no teor de ar incorporado foi proporcionalmente menos significativo para o módulo de elasticidade do que a adição dos $9 \%$ em relação ao concreto C40 de referência. No caso da classe $\mathrm{C} 25$, a diferença entre as curvas se apresenta de maneira mais proporcional em relação aos teores de 5,4\% e 11,7\% quando comparadas ao concreto referência.

Figura 4.14 - Concretos da classe C25 - Evolução do módulo de elasticidade dinâmico.

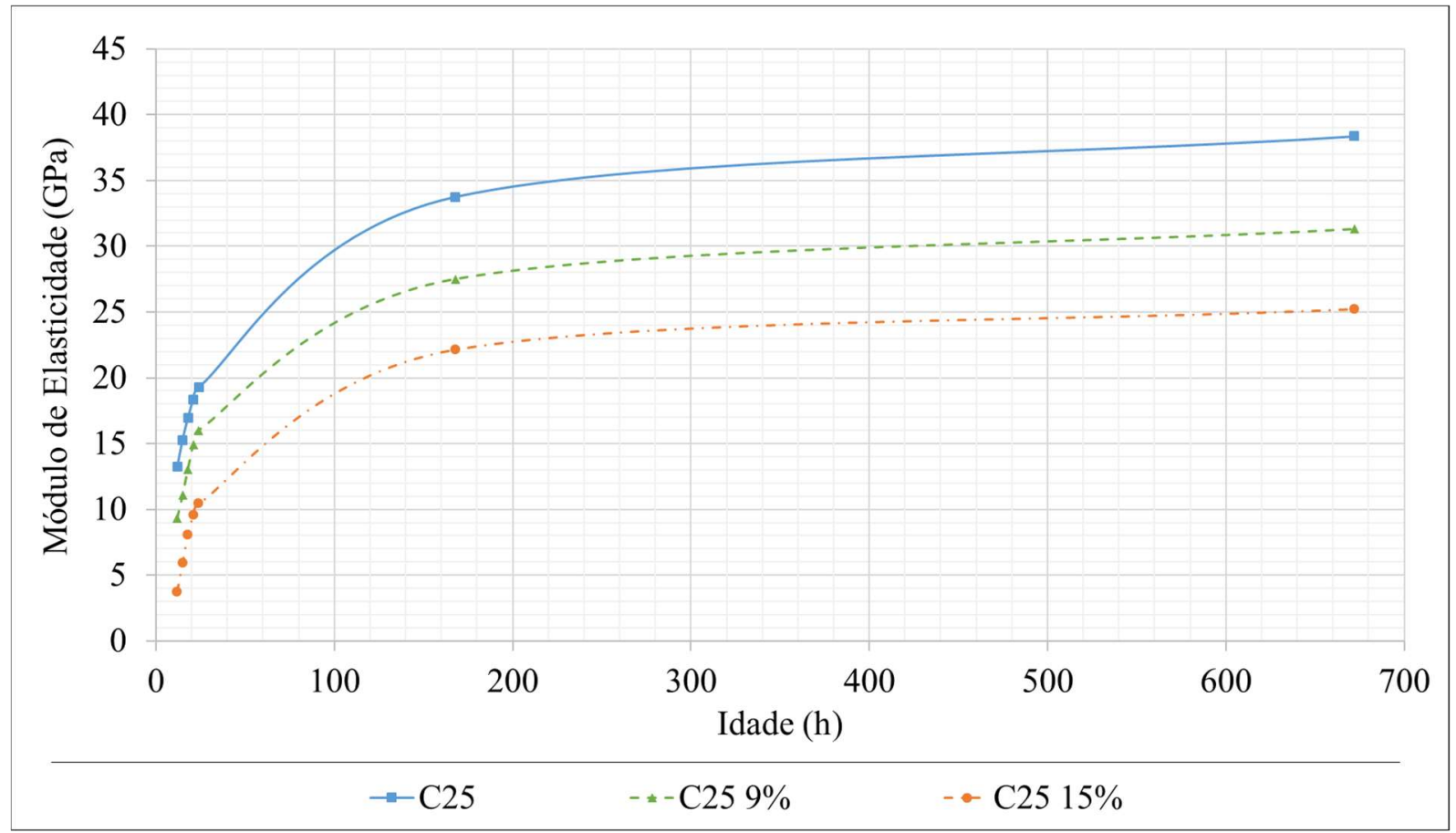

Fonte: Elaborada pelo autor. 
Figura 4.15 - Concretos da classe C40 - Evolução do módulo de elasticidade dinâmico.

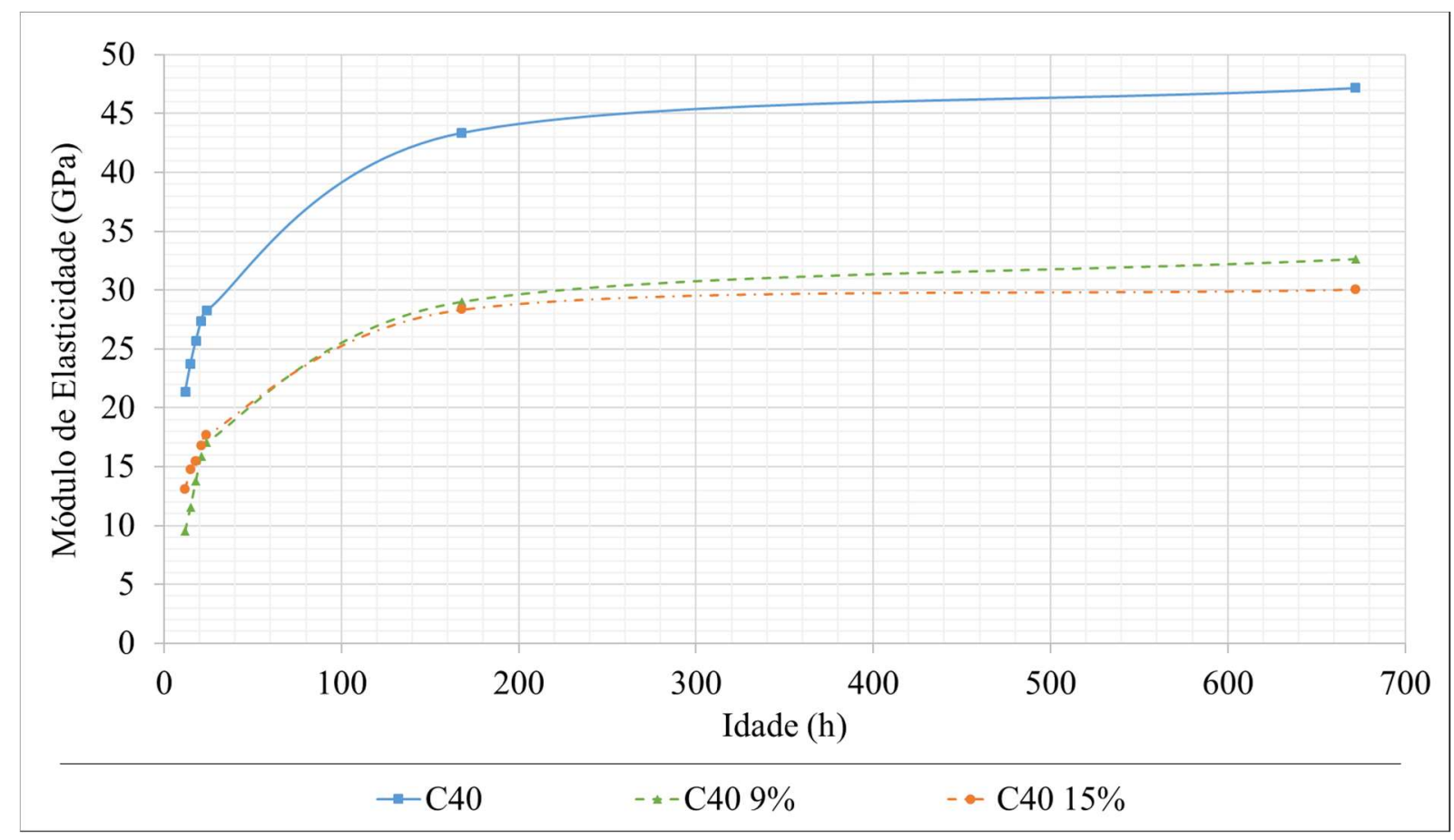

Fonte: Elaborada pelo autor.

- Comparação de vários parâmetros para os concretos produzidos:

Neste item, para cada concreto produzido e estudado neste trabalho, são apresentados gráficos (Figuras 4.16 a 4.21) correlacionando as diferentes propriedades do material no estado endurecido, isto é, os módulos de elasticidade e de cisalhamento dinâmicos, a resistência à compressão e a velocidade do pulso ultrassônico em todas as idades de ensaio. Os valores apresentados são referentes às médias obtidas em ensaios, com a ressalva para a velocidade do pulso ultrassônico no caso dos concretos com ar incorporado que, segundo teste t, apresenta diferença significativa entre as duas direções de análise. Ainda assim, para permitir uma comparação num contexto geral, foram consideradas as médias das velocidades nas duas direções. Soma-se a isso, o fato de que as curvas de velocidade referentes a cada direção por concreto seriam praticamente sobrepostas com a escala utilizada nos gráficos. 
Figura 4.16 - C25 referência - Comparação de parâmetros físicos ao longo do tempo.

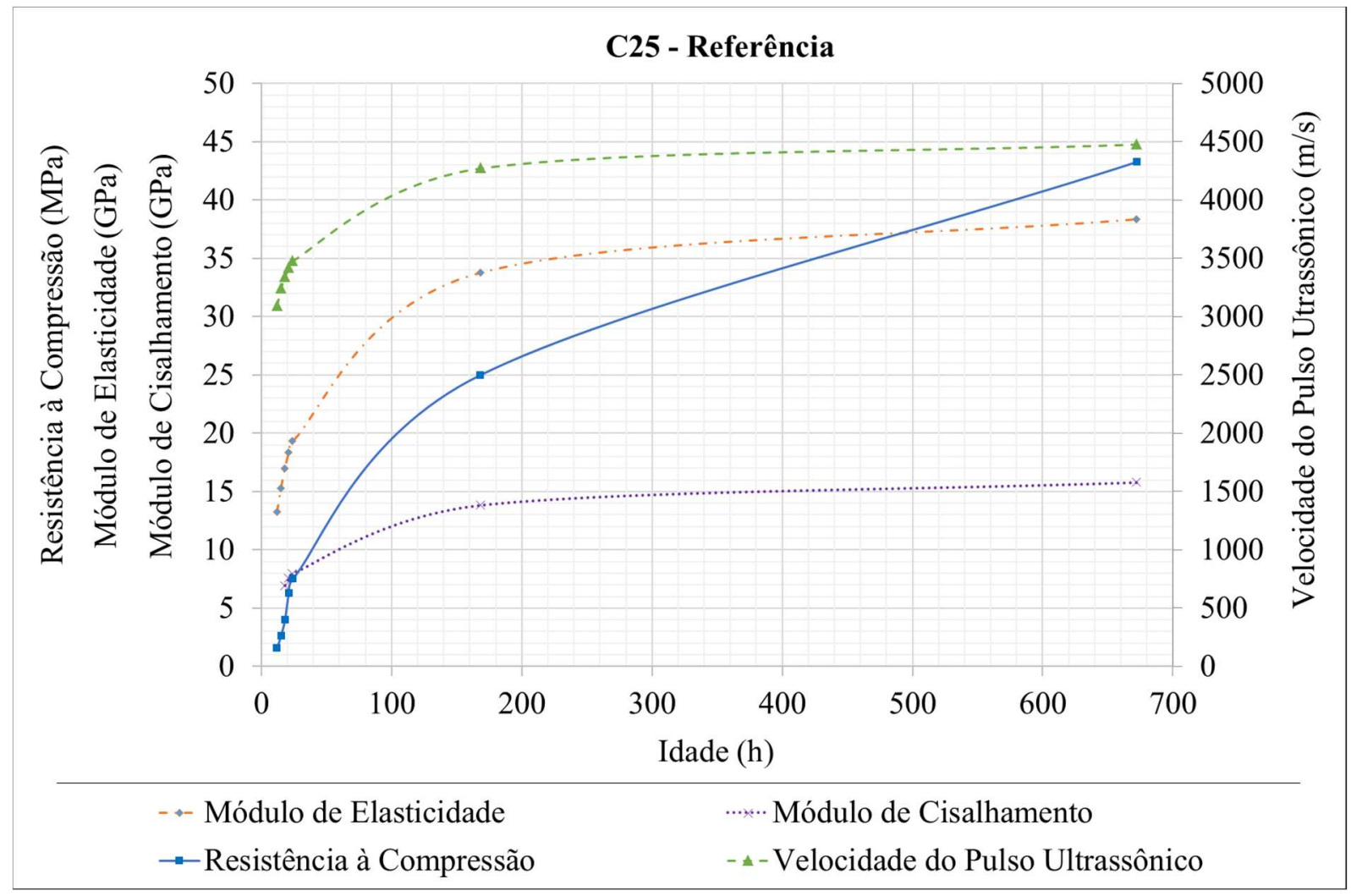

Fonte: Elaborada pelo autor.

Figura 4.17 - C25 9\% - Comparação de parâmetros físicos ao longo do tempo.

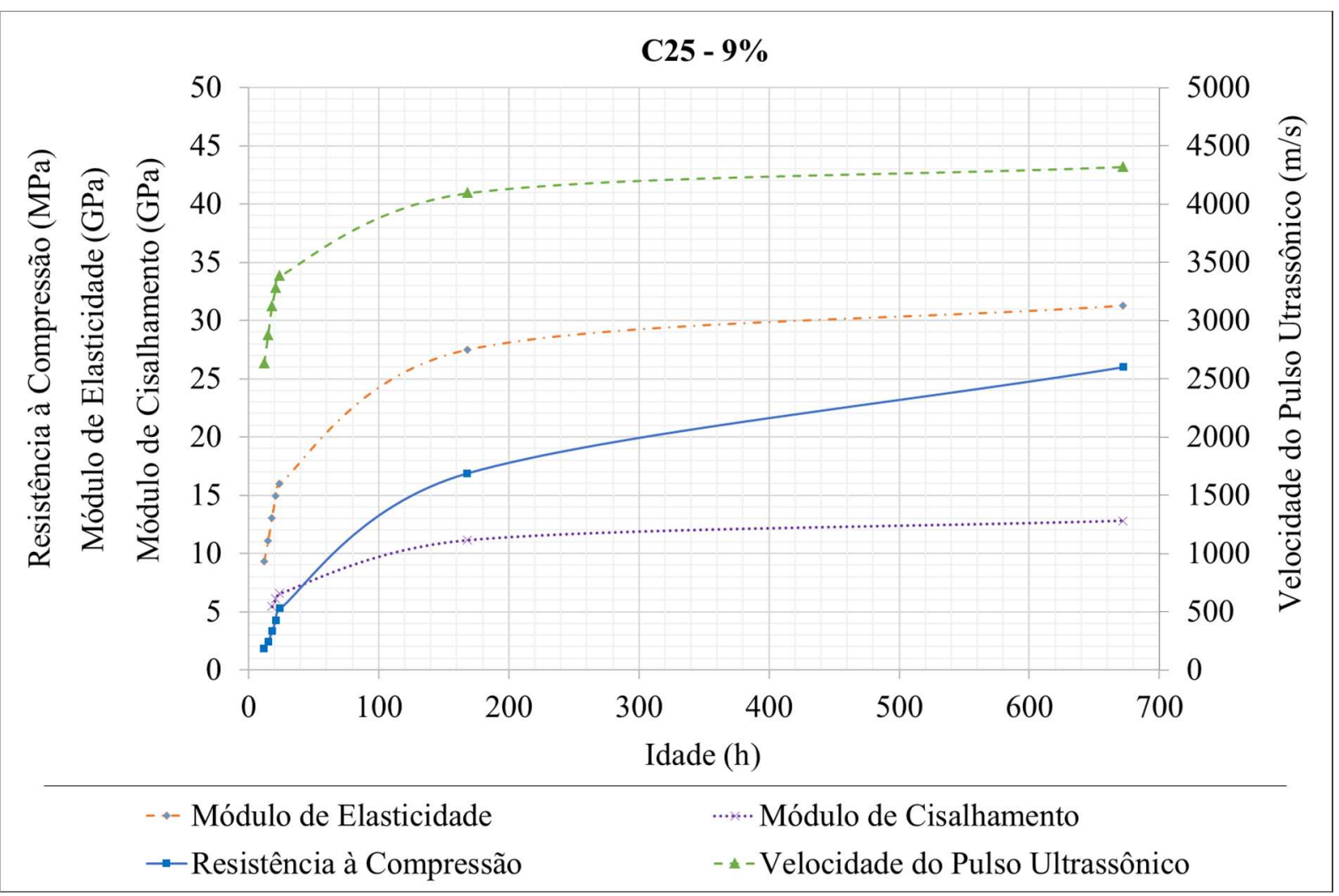

Fonte: Elaborada pelo autor. 
Figura 4.18 - C25 15\% - Comparação de parâmetros físicos ao longo do tempo.

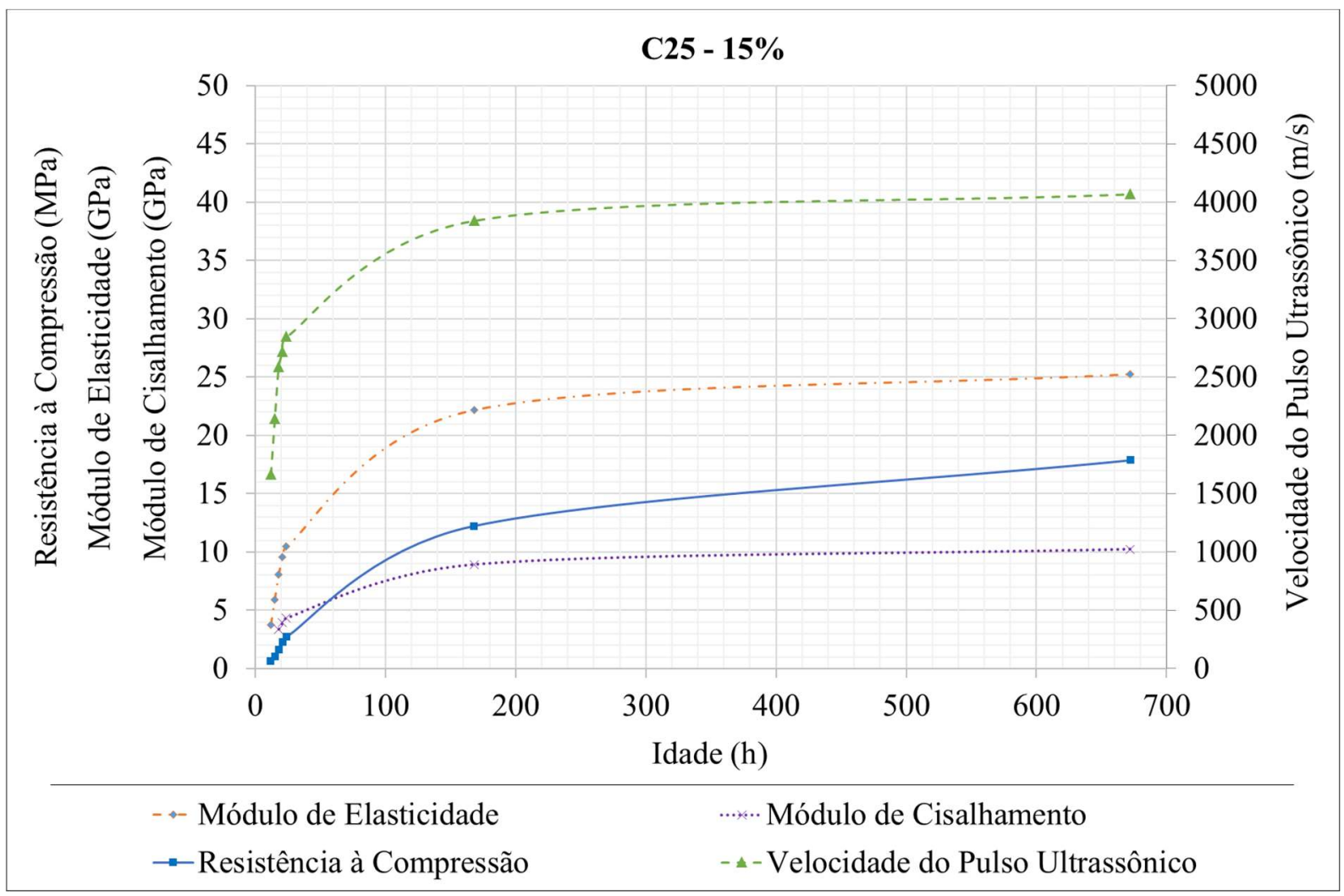

Fonte: Elaborada pelo autor.

Figura 4.19 - C40 referência - Comparação de parâmetros físicos ao longo do tempo.

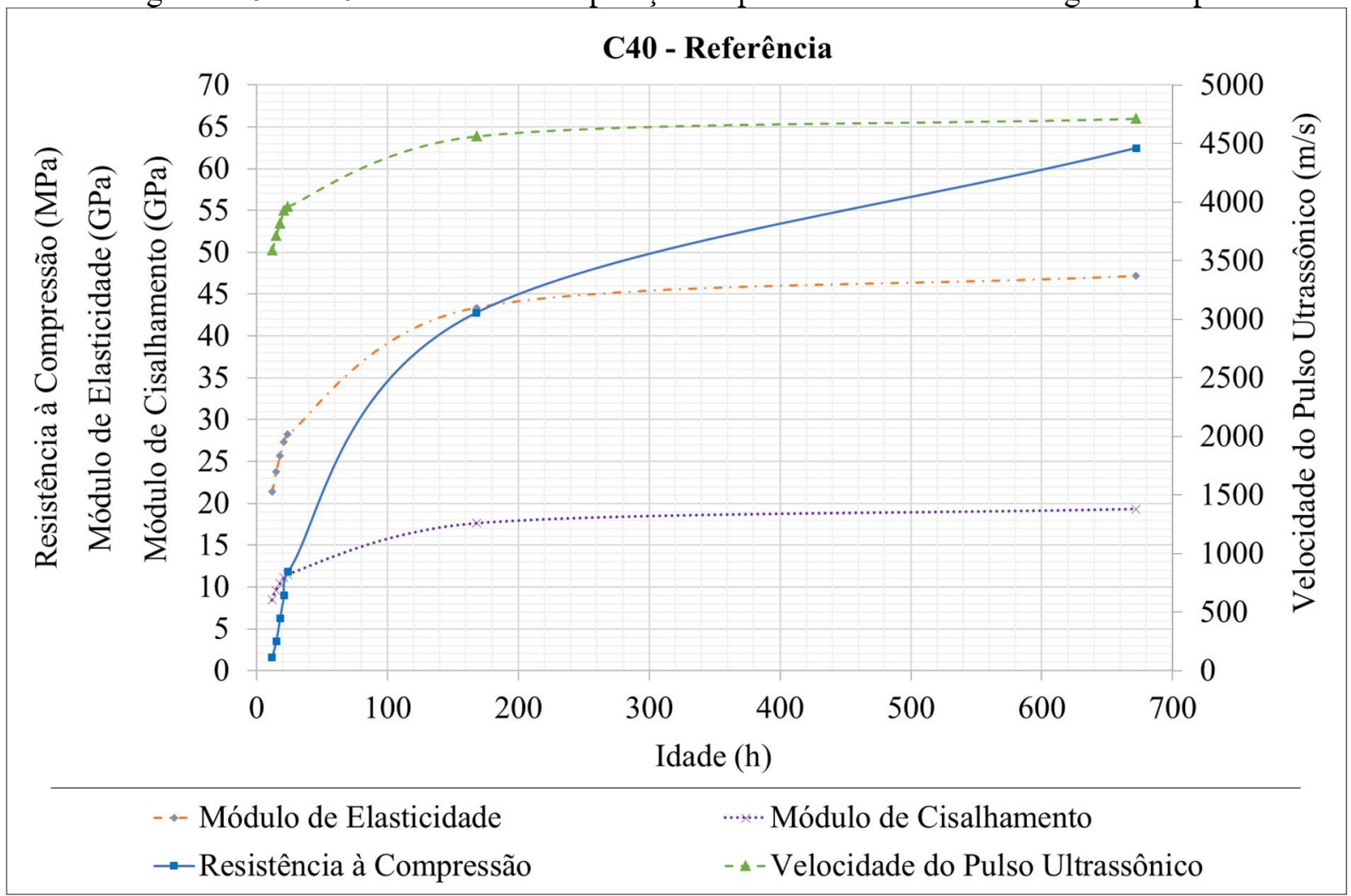

Fonte: Elaborada pelo autor. 
Figura 4.20-C40 9\% - Comparação de parâmetros físicos ao longo do tempo.

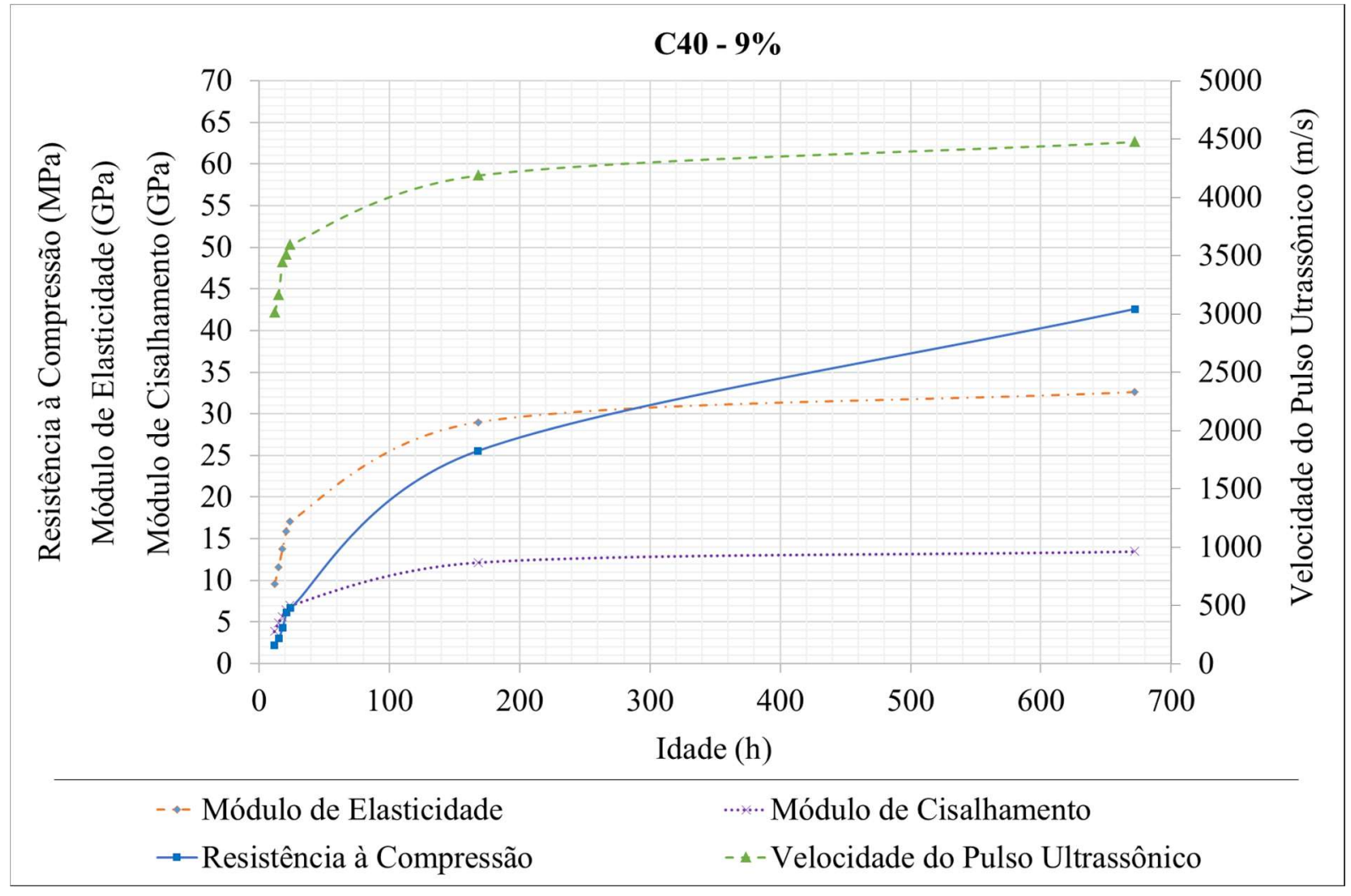

Fonte: Elaborada pelo autor.

Figura 4.21 - C40 15\% - Comparação de parâmetros físicos ao longo do tempo.

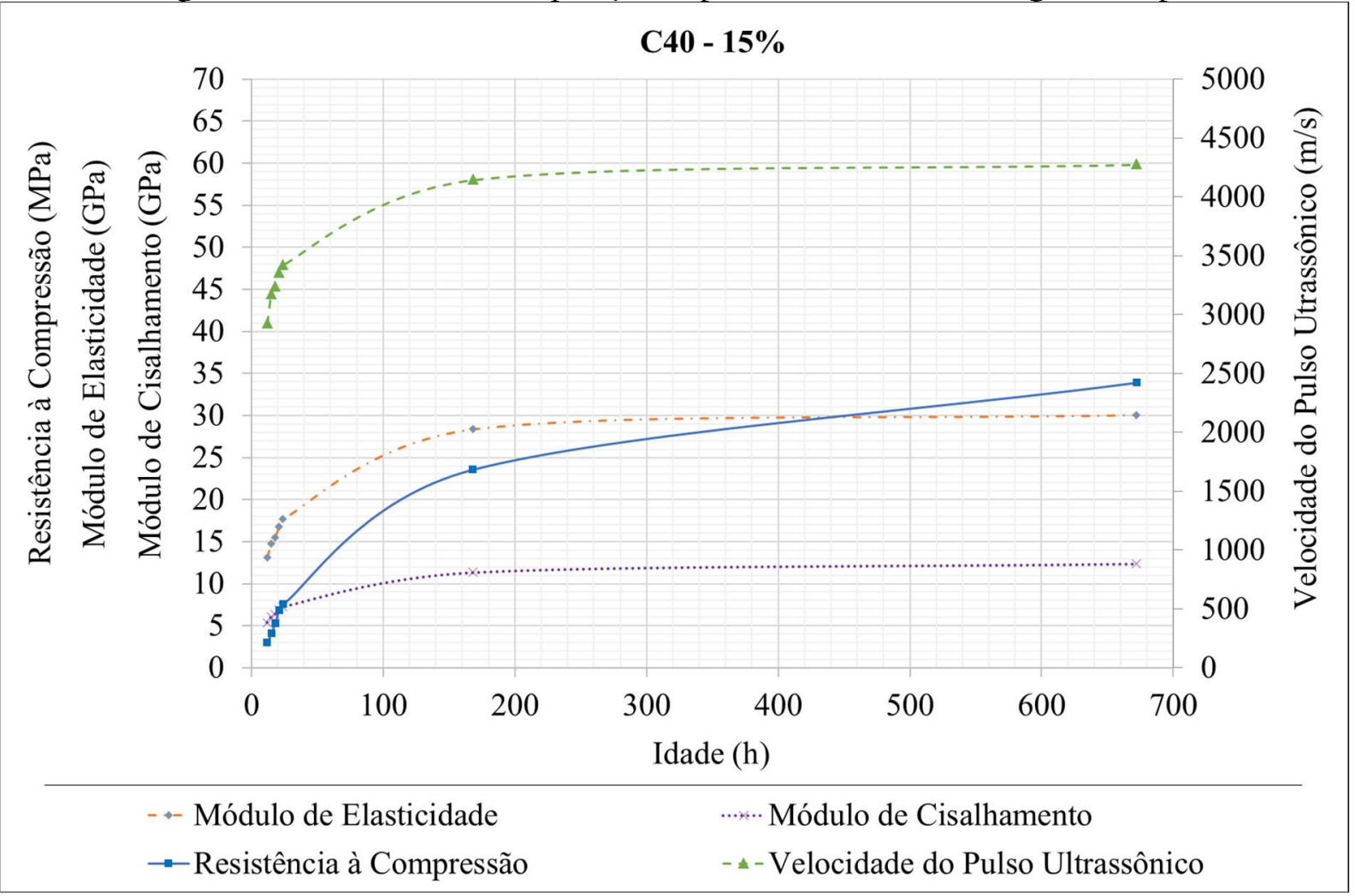

Fonte: Elaborada pelo autor. 
Os gráficos apresentados nas Figuras 4.16 a 4.21 mostram a tendência de as curvas de velocidade do pulso ultrassônico apresentarem a mesma configuração observada para os módulos de elasticidade dinâmicos. Isso ocorre porque, conforme ASTM C 597 (ASTM, 2016), a velocidade do pulso ultrassônico é proporcional ao valor do módulo de elasticidade, respeitando a seguinte relação (Equação 4.8):

$$
V=\sqrt{\frac{E \cdot(1-v)}{\rho \cdot(1+v) \cdot(1-2 v)}}
$$

Onde:

$E$ é o módulo de elasticidade dinâmico;

$v$ é o coeficiente de Poisson;

$\rho$ é a densidade.

Outra análise de interesse é referente às curvas dos módulos dinâmicos. Como apresentado anteriormente, o módulo de elasticidade e o módulo de cisalhamento são diretamente proporcionais e dependem do valor do coeficiente de Poisson. Por sua vez, o coeficiente de Poisson apresenta certa variação ao longo das idades de ensaio. Isso faz com que as curvas dos módulos dinâmicos apresentem inclinações diferentes para primeiras idades, enquanto que, após os 7 dias as inclinações são praticamente as mesmas.

Observa-se também a tendência de estabilização dos valores de velocidade do pulso ultrassônico e dos módulos de elasticidade e de cisalhamento com a aproximação da idade de 28 dias. Por outro lado, para as idades analisadas, a resistência à compressão não apresenta essa estabilização, o que indica uma tendência de ganho de resistência após os 28 dias. 


\subsection{Análises em modelos (painéis) reais de paredes}

\subsubsection{Concretagem das paredes}

Após toda a caracterização nos estados fresco e endurecido para os traços propostos, foi iniciada a etapa de concretagem dos modelos de paredes. Inicialmente, pensou-se na concretagem dos seis traços desenvolvidos. Porém, devido às baixas resistências obtidas para os traços de classe C25 com ar incorporado, optou-se apenas pela concretagem dos 3 traços de classe $\mathrm{C} 40$.

- Parede com concreto C40 de referência:

A primeira parede foi concretada com o traço $\mathrm{C} 40$ de referência. $\mathrm{O}$ volume necessário para o preenchimento da parede é de 200 litros. Apesar de muito elevado, optou-se pela mistura de todo o volume em uma única betonada para evitar possíveis juntas no modelo concretado. Dessa forma, considerando uma possível perda de 10\%, foi utilizada betoneira vertical de grande capacidade para a mistura dos 220 litros necessários para a concretagem da parede.

Durante a mistura dos materiais para confecção das paredes, houve certa dificuldade na obtenção do espalhamento, sendo observada perda em relação ao traço caracterizado previamente. Apesar de identificada essa perda de espalhamento, decidiu-se pelo prosseguimento da concretagem porque a mistura já vinha sendo feita há bastante tempo e a quantidade de materiais envolvida era muito grande para correr o risco de perder a betonada. As duas medidas do espalhamento foram $600 \mathrm{~mm}$ e $610 \mathrm{~mm}$, resultando em valor médio de $605 \mathrm{~mm}$.

A concretagem das paredes com 1,5 m de altura foi viabilizada com a utilização de uma empilhadeira para erguer duas pessoas e uma carriola carregada com concreto. Foram utilizadas quatro carriolas de maneira a proporcionar um fluxo contínuo de preenchimento da fôrma e ainda para evitar perda de espalhamento. Durante o processo, as carriolas eram carregadas de concreto na betoneira e levadas até a empilhadeira, criando um revezamento que demandou um total de 7 pessoas por concretagem. A Figura 4.22 exemplifica o procedimento de concretagem. 
Figura 4.22 - Procedimento de concretagem das paredes.
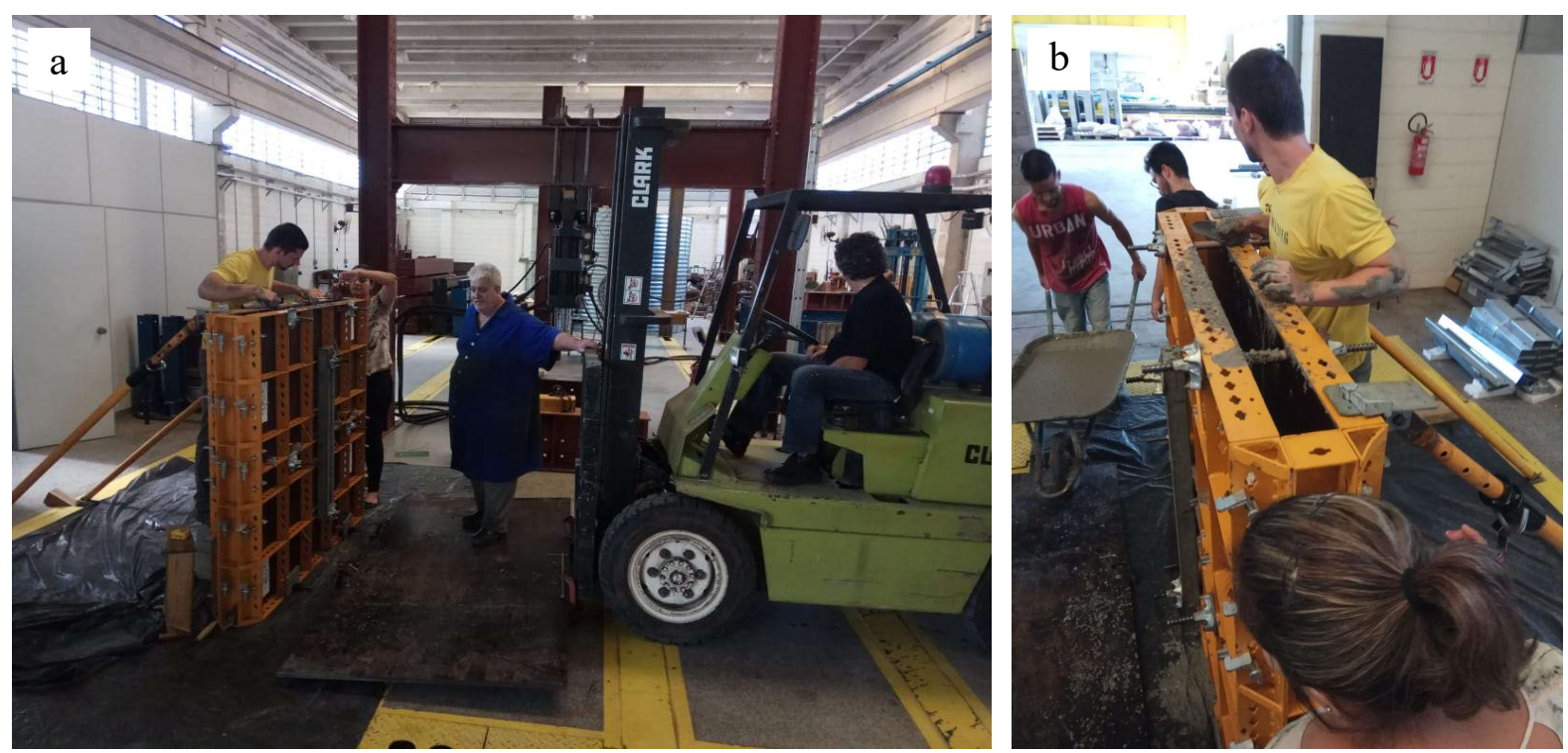

Fonte: Arquivo pessoal.

Durante a concretagem da parede com C40 de referência houve um contratempo que mudou o formato pretendido para o modelo. A fôrma de madeira montada para delimitar a janela central cedeu, fazendo com que o concreto preenchesse essa região que deveria ser vazada. Ainda assim, a falha da fôrma em questão se deu após o concreto alcançar cerca de $75 \mathrm{~cm}$ (metade da altura da parede), de maneira que o obstáculo imposto pela janela já tivesse sido vencido. Como a região central da parede passou a ser preenchida, o concreto misturado foi suficiente apenas para uma altura de aproximadamente $145 \mathrm{~cm}$, ou seja, a parede ficou com altura inferior aos $150 \mathrm{~cm}$ previstos inicialmente. Apesar do exposto, considerou-se que o modelo estava apto a ser ensaiado, sem a necessidade de uma nova concretagem. A Figura 4.23 apresenta uma visão geral da parede concretada com o traço C40 de referência. 
Figura 4.23 - C40 referência - Parede concretada.

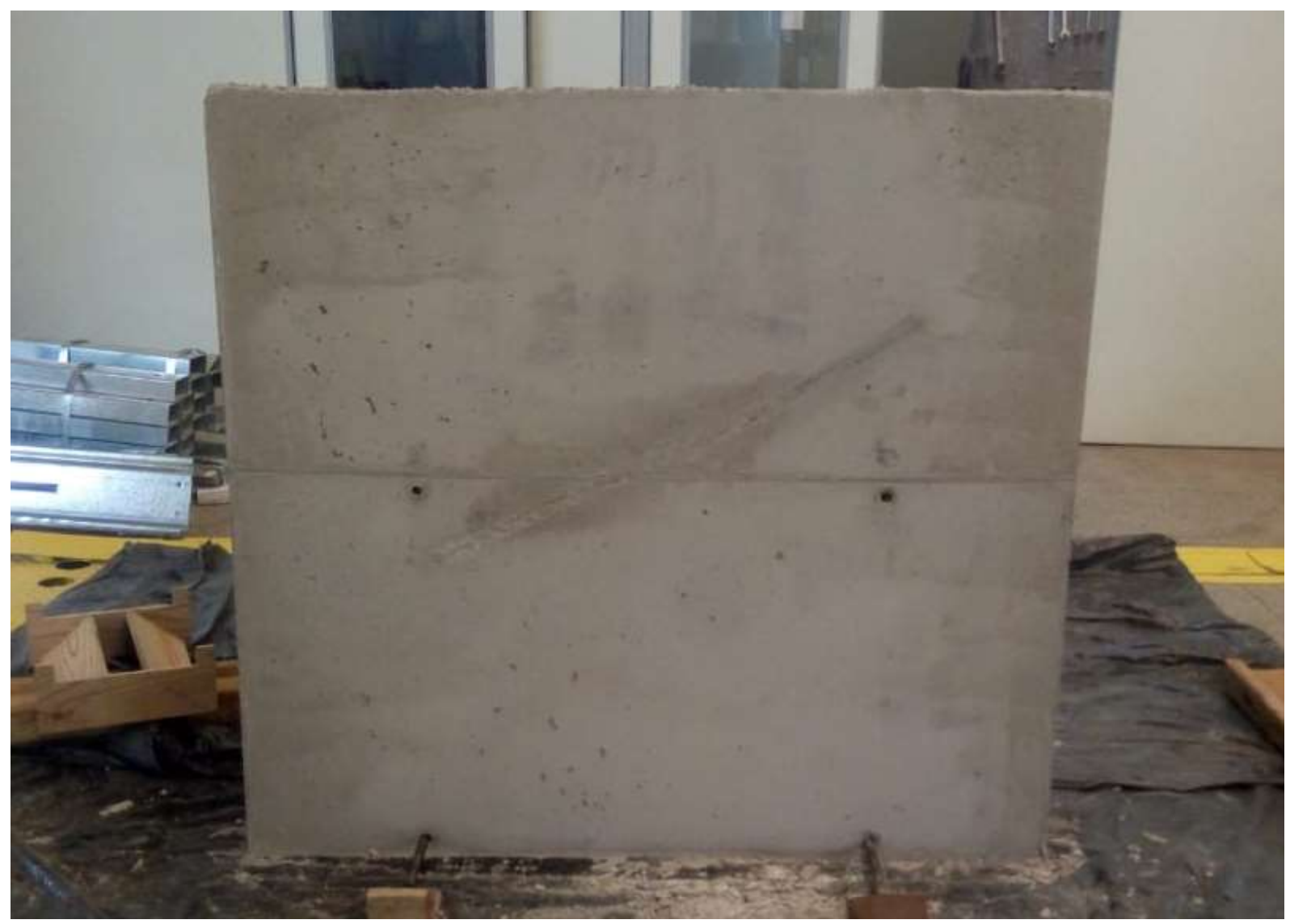

Fonte: Arquivo pessoal.

- Parede com concreto C40 9\%:

Com a experiência adquirida após a concretagem do primeiro modelo, algumas mudanças foram adotadas visando a correção de falhas. Dentre elas, foi feito um reforço da fôrma da janela central, sendo agora utilizadas peças de madeira com maior espessura e feito também um reforço interno com isopor de alta densidade. Outra medida foi a de aumentar a quantidade de superplastificante utilizada, a fim de compensar a perda de espalhamento decorrente do maior tempo de mistura com o aditivo incorporador de ar. O teor de superplastificante utilizado foi de $1,09 \%$ em relação à massa de cimento.

A segunda parede concretada utilizou o traço C40 9\%. O volume total de concreto também foi produzido em apenas uma betonada, mantendo o padrão adotado para o primeiro modelo. A diferença é que nessa concretagem, foi necessário o acompanhamento constante da massa do concreto para definição do teor de ar incorporado, seguindo o procedimento utilizado na caraterização do traço em questão. 
A massa de aditivo incorporador de ar utilizada foi correspondente a um teor de $0,3 \%$ em relação à massa de cimento. Foi considerada quantidade maior de aditivo em relação ao estudo do traço na tentativa de reduzir o tempo total de mistura a fim de que o espalhamento não fosse muito prejudicado, já que o volume de concreto total era muito elevado. A mistura foi cessada após 9 minutos (mistura efetiva sem contabilizar o tempo com betoneira parada para operações de pesagem) quando se verificou um teor de ar incorporado de $8,6 \%$, próximo do valor alvo de $9 \%$, correspondente à média obtida para o concreto caracterizado anteriormente. As medidas de espalhamento do concreto foram de $700 \mathrm{~mm}$ e $720 \mathrm{~mm}$, com valor médio de $710 \mathrm{~mm}$. A Figura 4.24 apresenta o modelo concretado com o traço C40 9\%.

Figura 4.24 - C40 9\% - Parede concretada.

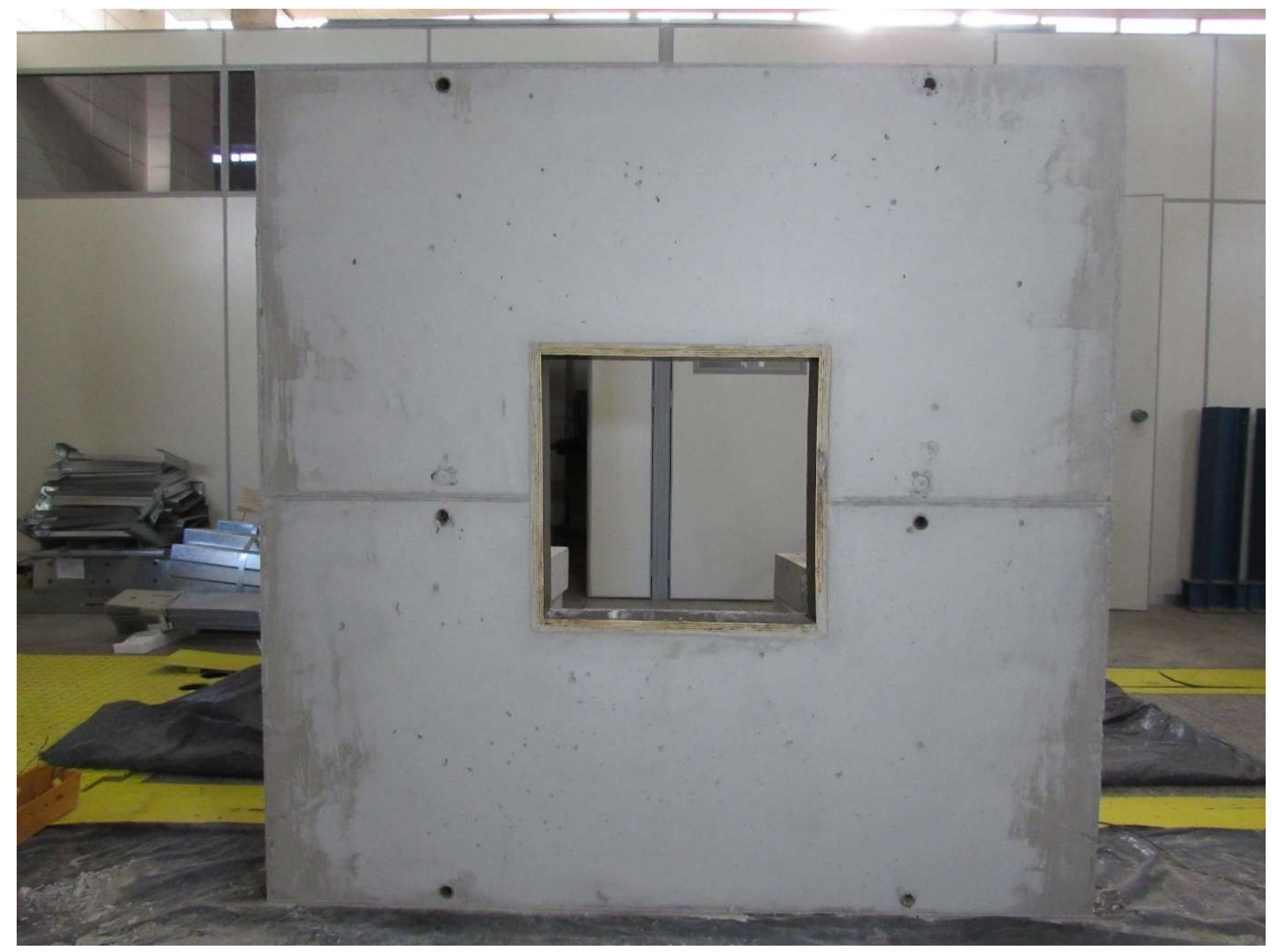

Fonte: Arquivo pessoal.

Como pode ser observado, a concretagem desse segundo modelo seguiu sem problemas, resultando em estrutura com as dimensões propostas inicialmente. 
- Parede com concreto C40 15\%:

Por fim, a concretagem da terceira e última parede seguiu o mesmo procedimento adotado na segunda parede, sendo agora utilizado o traço C40 15\%. O teor de superplastificante utilizado foi de 1,09\% em relação à massa de cimento, enquanto que a de aditivo incorporador de ar foi de $0,3 \%$ da massa de cimento. Após aproximadamente 12 minutos de mistura efetiva, foi obtido um teor de ar de 13,6\%, próximo do valor alvo de 14,1\% obtido quando do estudo do traço de concreto autoadensável com alto teor de ar incorporado. As medidas de espalhamento foram de $720 \mathrm{~mm}$ e $740 \mathrm{~mm}$, com valor médio de $730 \mathrm{~mm}$. Novamente, a concretagem seguiu sem problemas. A Figura 4.25, mostra o resultado da parede.

Figura 4.25 - C40 15\% - Parede concretada.

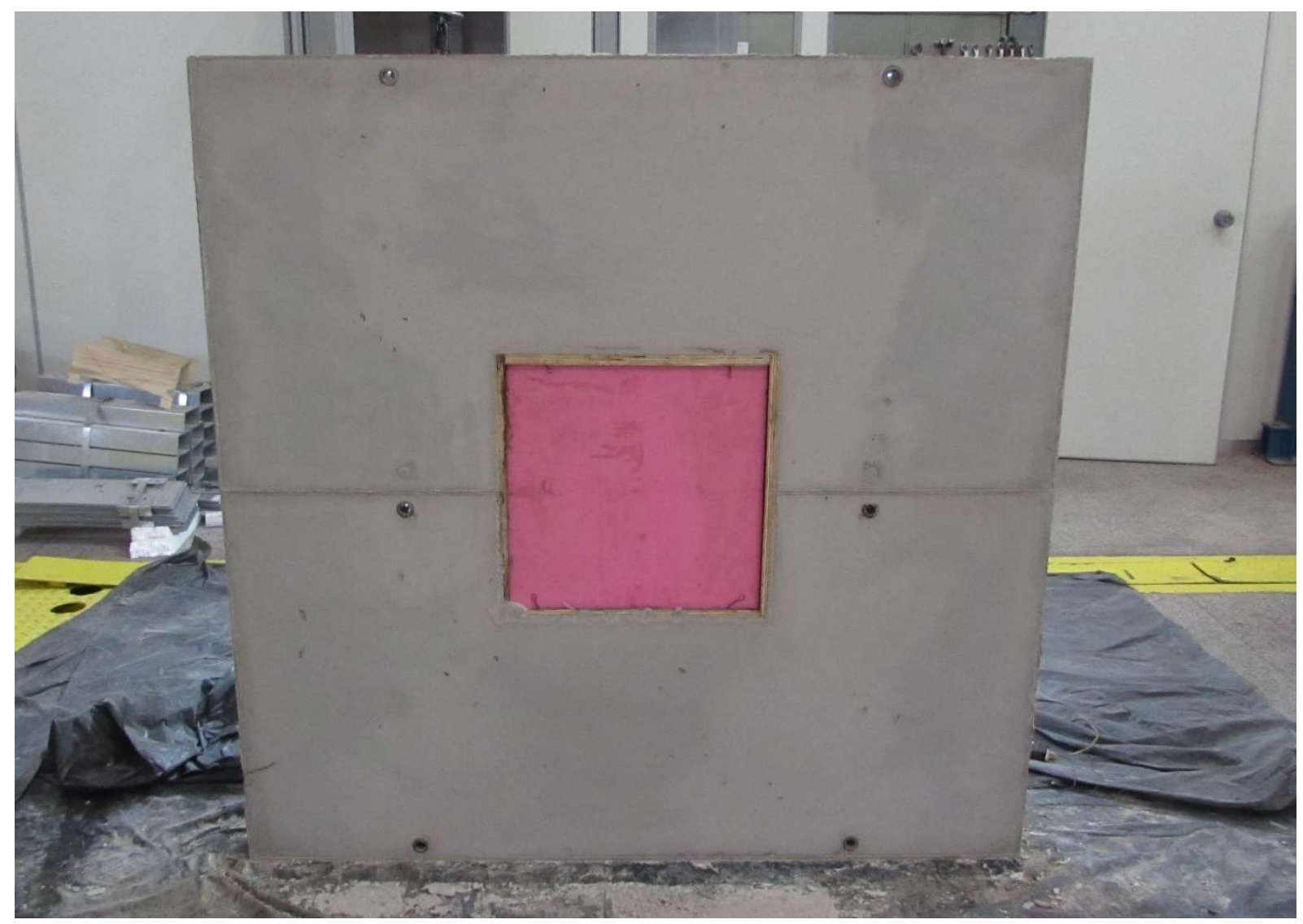

Fonte: Elaborada pelo autor.

Vale destacar que não foi utilizado nenhum processo de cura nas paredes. Isso se deu porque a posição vertical dos modelos prejudicaria a manutenção de água na superfície, 
sendo que a região do laboratório na qual as paredes eram concretadas não poderia ficar úmida e ainda porque não havia material nem ferramentas necessárias para aplicação de cura química.

Considerou-se, entretanto, que esse fator não apresentaria grande interferência nas análises por não serem desenvolvidos ensaios de resistência nesses modelos, além de que as paredes ficavam protegidas da irradiação solar por estarem dentro de galpão fechado. Em visita técnica na cidade de São Carlos/SP, foi observado que o empreendimento em construção com o sistema de paredes de concreto moldadas no local também não fazia uso de nenhum método para cura do concreto. Ainda assim, o processo de cura deve ser realizado de maneira adequada, a fim de evitar o aparecimento de fissuras (ABNT, 2014a) e garantir o ganho de resistência.

\subsubsection{Análise do acabamento superficial}

Com as paredes concretadas, puderam ser feitas as análises finais deste trabalho. A primeira delas consiste na análise do acabamento superficial com auxílio de software de tratamento de imagens. É importante destacar que as falhas superficiais causadas diretamente pelas fôrmas utilizadas foram descartadas da análise. Essas falhas consistem nos furos originados pela passagem dos tirantes que travam os painéis das fôrmas, nos arames que travam a janela de madeira (podendo ficar expostos superficialmente), nas peças de madeira utilizadas para delimitar a janela e ainda por pequenos rebites fixados na parte interna dos painéis que entram em contato com o concreto. As regiões de análise estão indicadas na Figura 4.26.

Figura 4.26 - Quadrantes para análise do acabamento superficial.
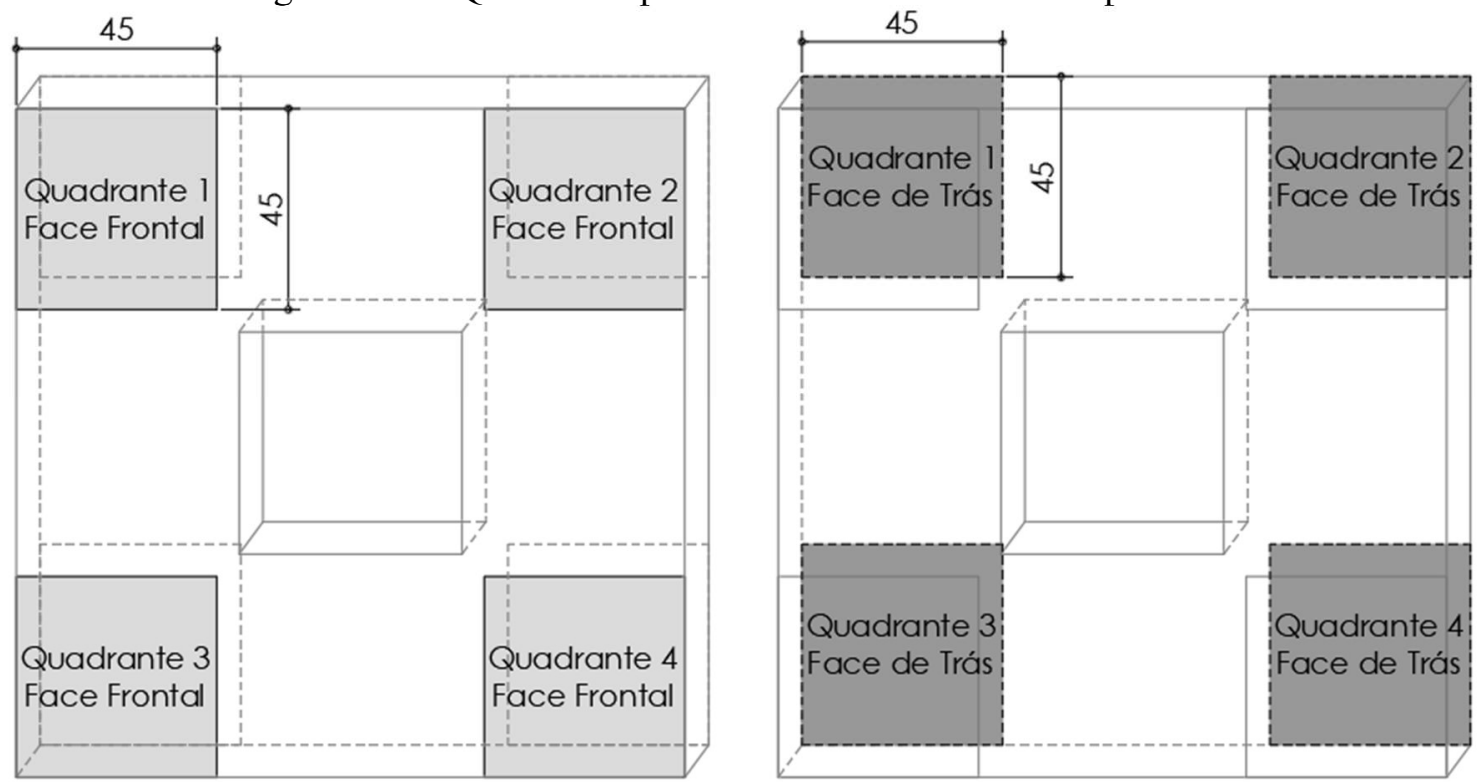

Fonte: Elaborada pelo autor. 
$\mathrm{Na}$ sequência estão apresentadas as análises realizadas com o software ImageJ para os 4 quadrantes da face frontal e os 4 da face de trás de cada uma das três paredes. Em cada conjunto de imagens são apresentadas a porcentagem de falha superficial identificada e a nota referente ao acabamento conforme metodologia apresentada. Vale destacar que esses resultados serão discutidos de maneira conjunta após apresentação das análises do acabamento superficial das três paredes.

- Parede com concreto C40 de referência:

Figura 4.27 - Parede C40 referência, Quadrante 1, Face Frontal - Falha: 1,339\%; Nota: 3,45.

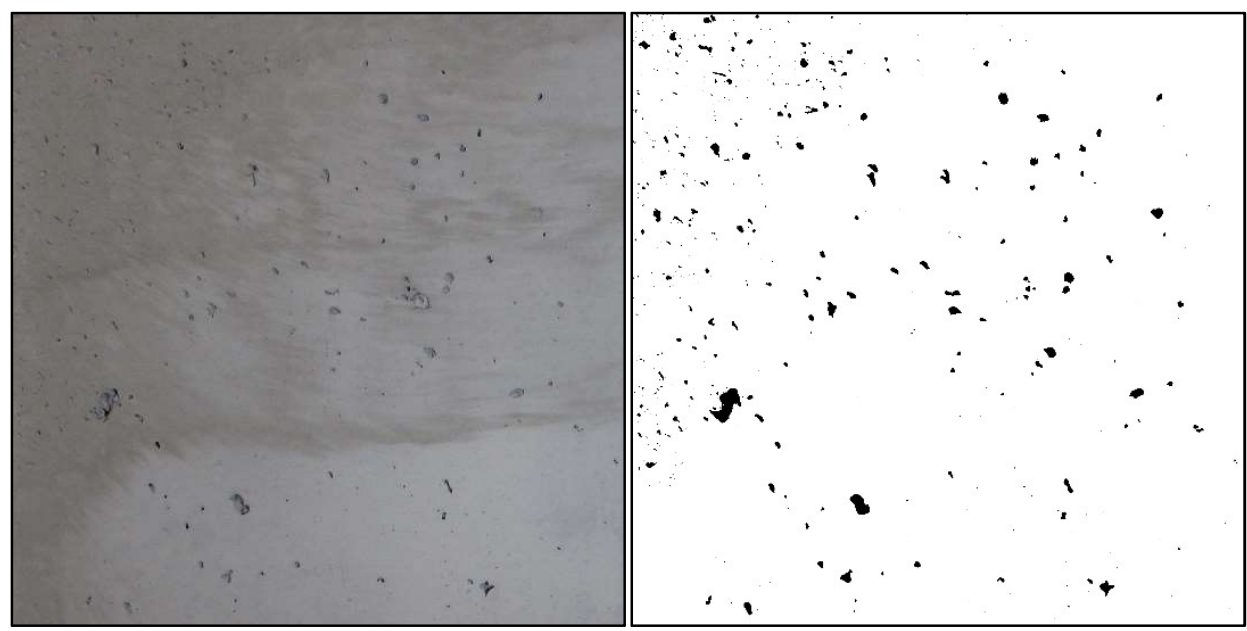

Fonte: Elaborada pelo autor.

Figura 4.28 - Parede C40 referência, Quadrante 2, Face Frontal - Falha: 0,578\%; Nota: 3,07.

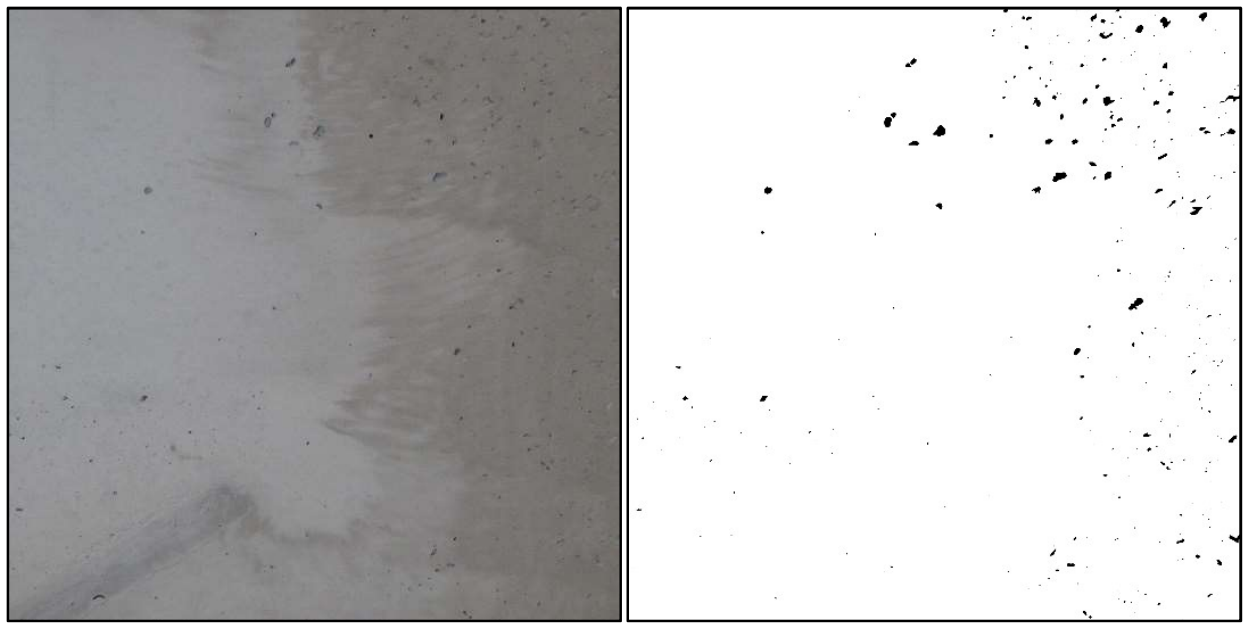

Fonte: Elaborada pelo autor. 
Figura 4.29 - Parede C40 referência, Quadrante 3, Face Frontal - Falha: 0,375\%; Nota: 2,70.

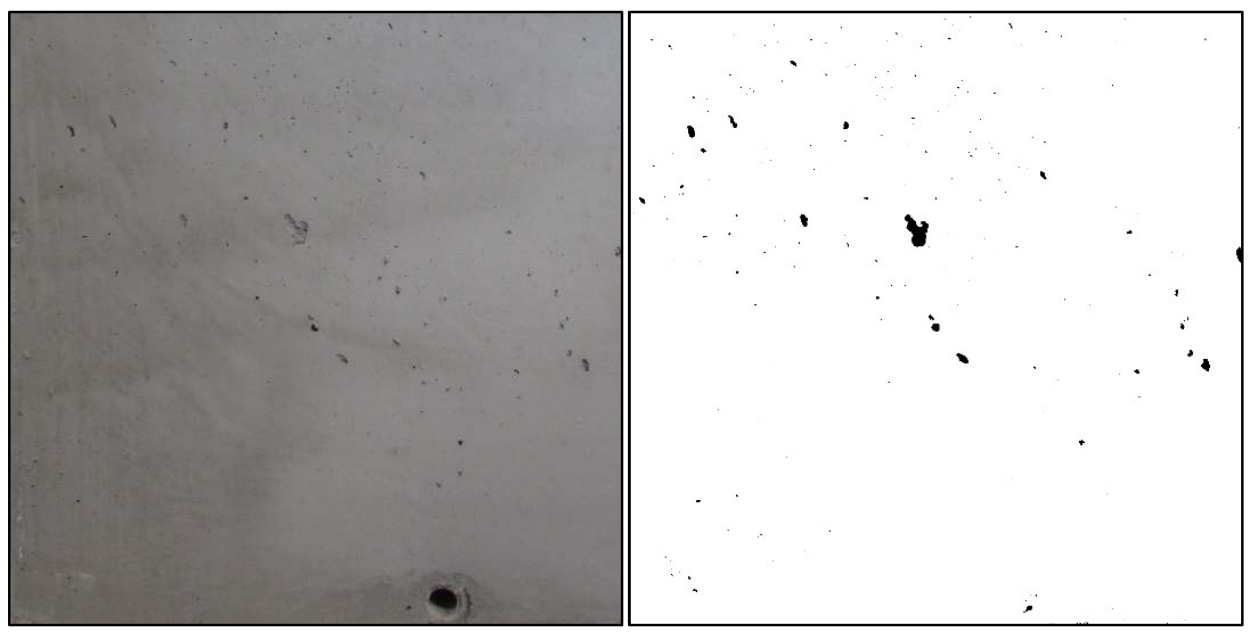

Fonte: Elaborada pelo autor.

Figura 4.30 - Parede C40 referência, Quadrante 4, Face Frontal - Falha: 0,138\%; Nota: 1,57.

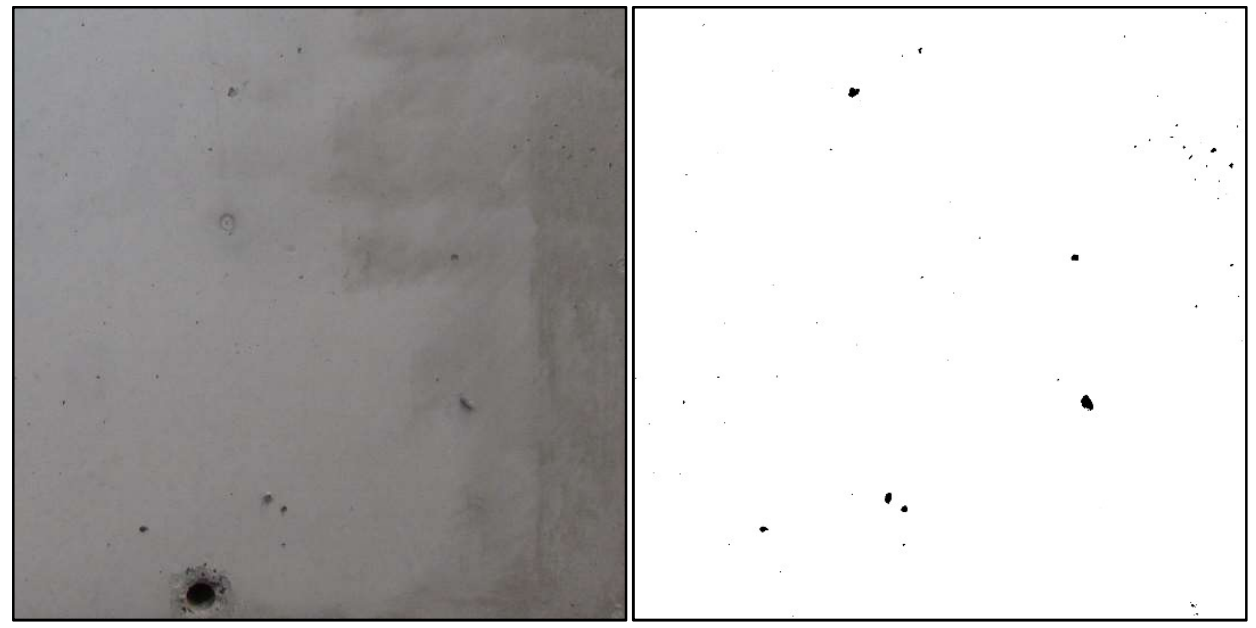

Fonte: Elaborada pelo autor.

Figura 4.31 - Parede C40 referência, Quadrante 1, Face de Trás - Falha: 1,116\%; Nota: 3,34.

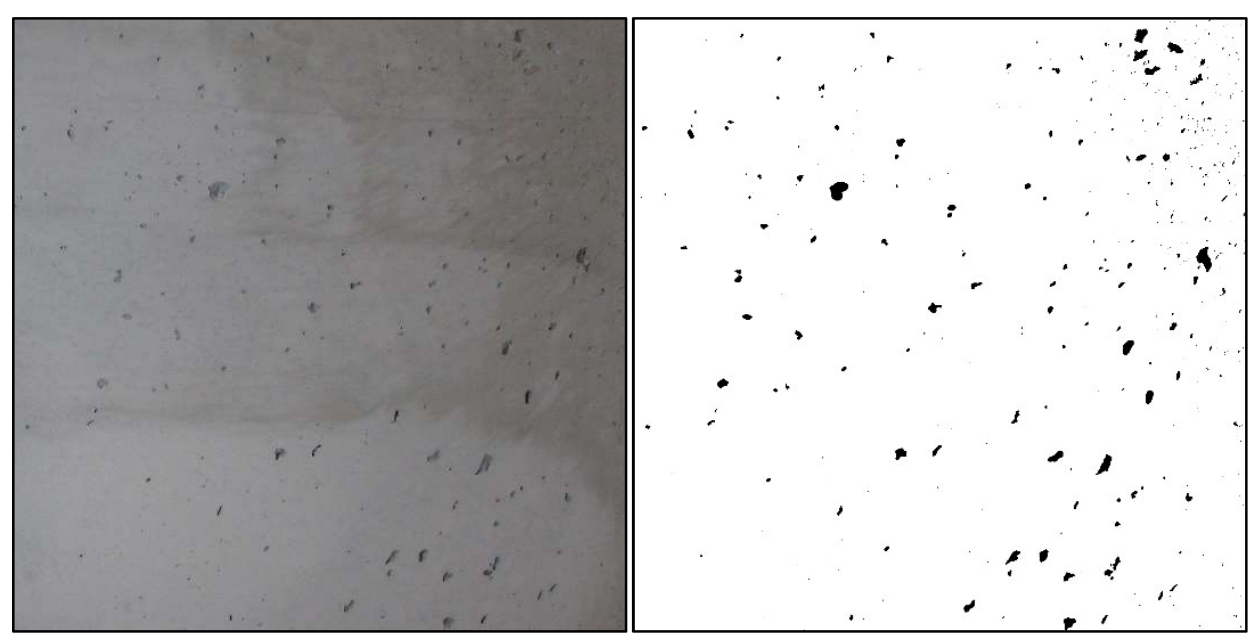

Fonte: Elaborada pelo autor. 
Figura 4.32 - Parede C40 referência, Quadrante 2, Face de Trás - Falha: 0,779\%; Nota: 3,17.

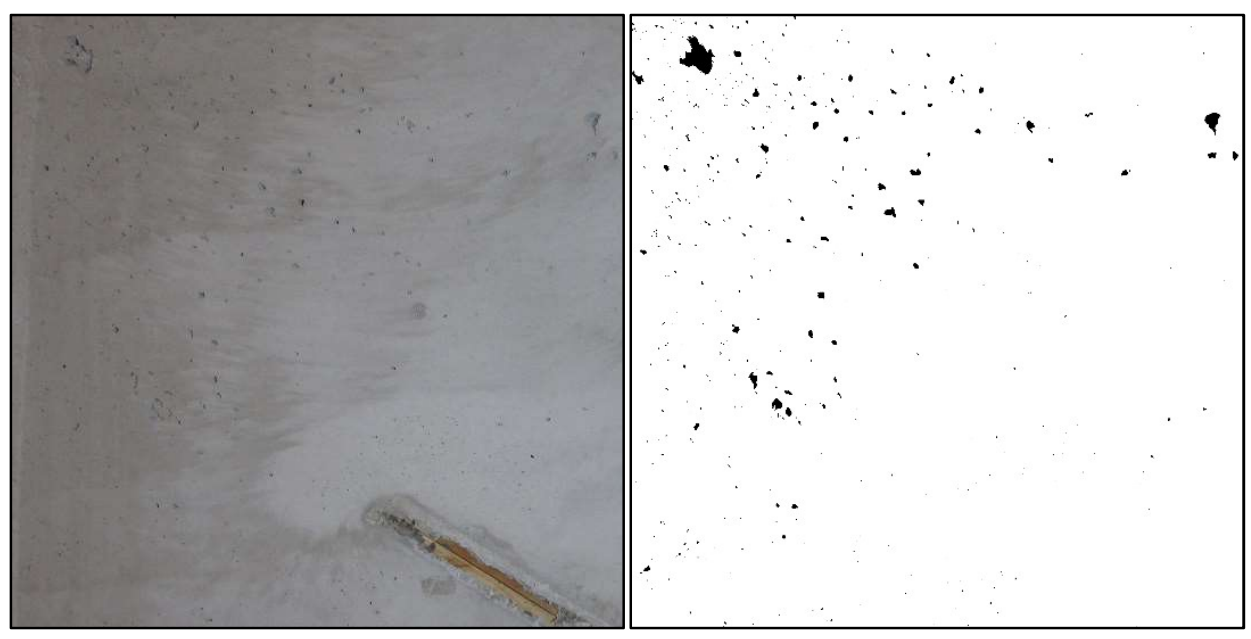

Fonte: Elaborada pelo autor.

Figura 4.33 - Parede C40 referência, Quadrante 3, Face de Trás - Falha: 0,194\%; Nota: 1,96.

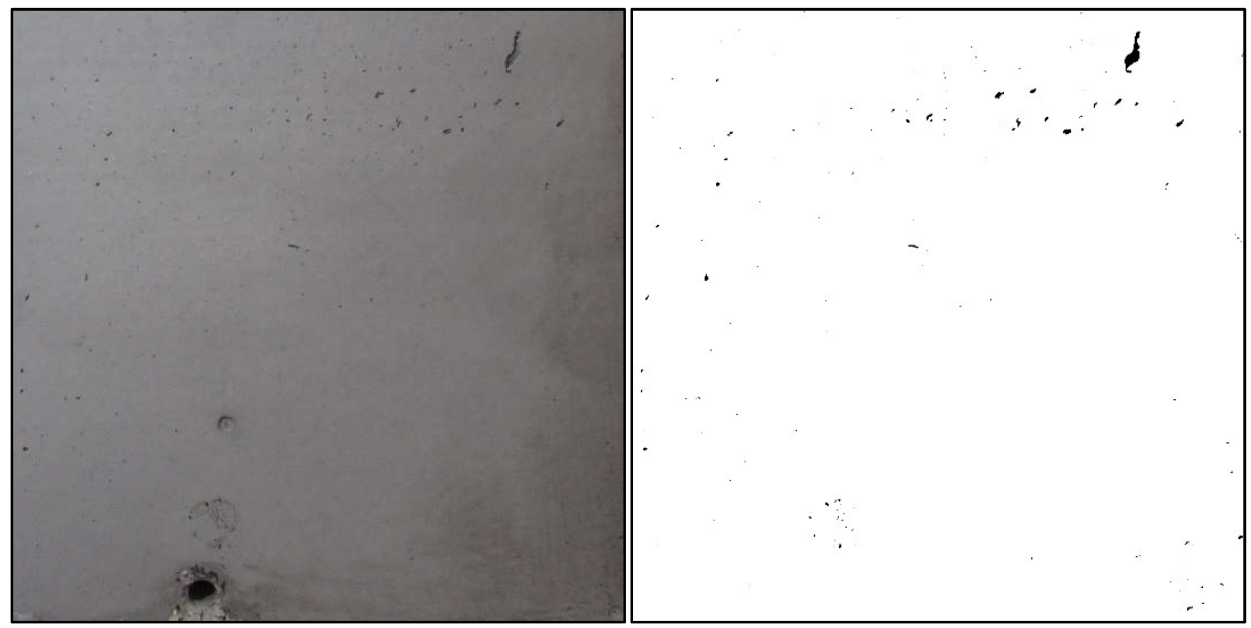

Fonte: Elaborada pelo autor.

Figura 4.34 - Parede C40 referência, Quadrante 4, Face de Trás - Falha: 0,115\%; Nota: 1,40.

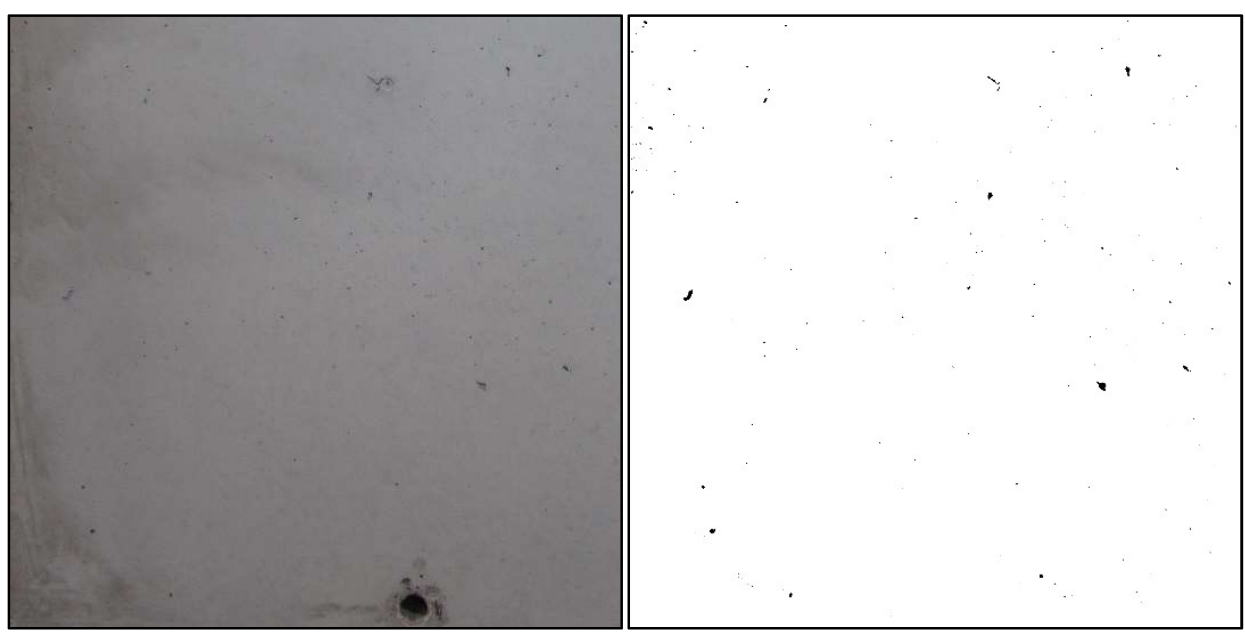

Fonte: Elaborada pelo autor. 
- Parede com concreto C40 9\%:

Figura 4.35 - Parede C40 9\%, Quadrante 1, Face Frontal - Falha: 0,120\%; Nota: 1,44.

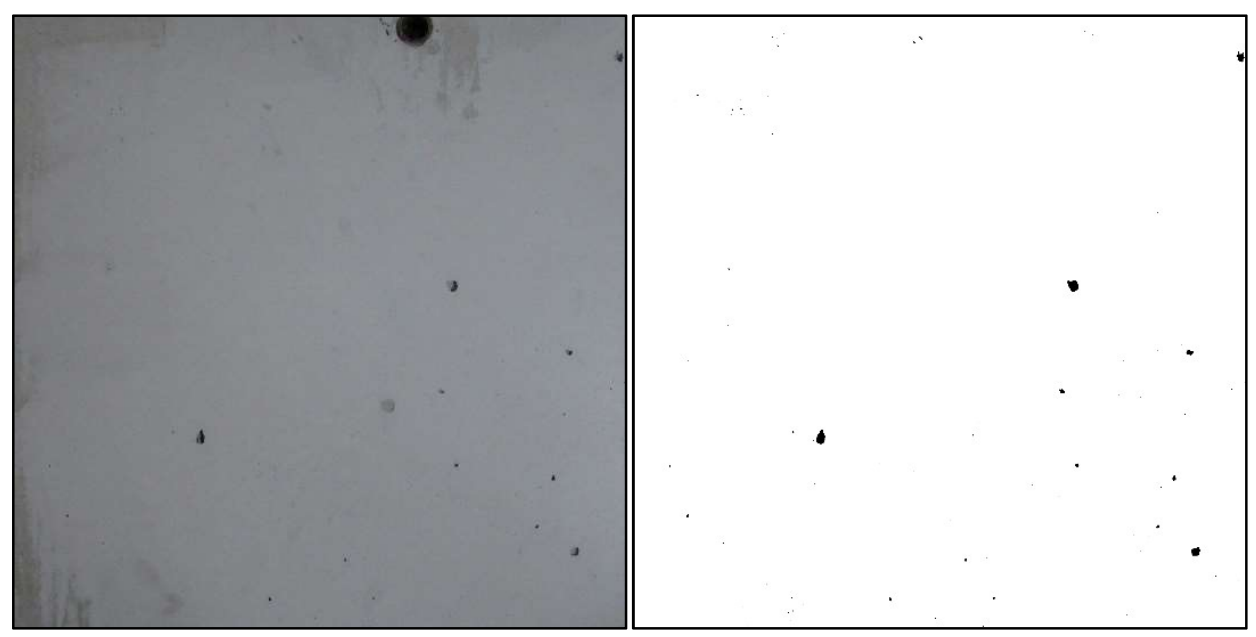

Fonte: Elaborada pelo autor.

Figura 4.36 - Parede C40 9\%, Quadrante 2, Face Frontal - Falha: 0,171\%; Nota: 1,80.

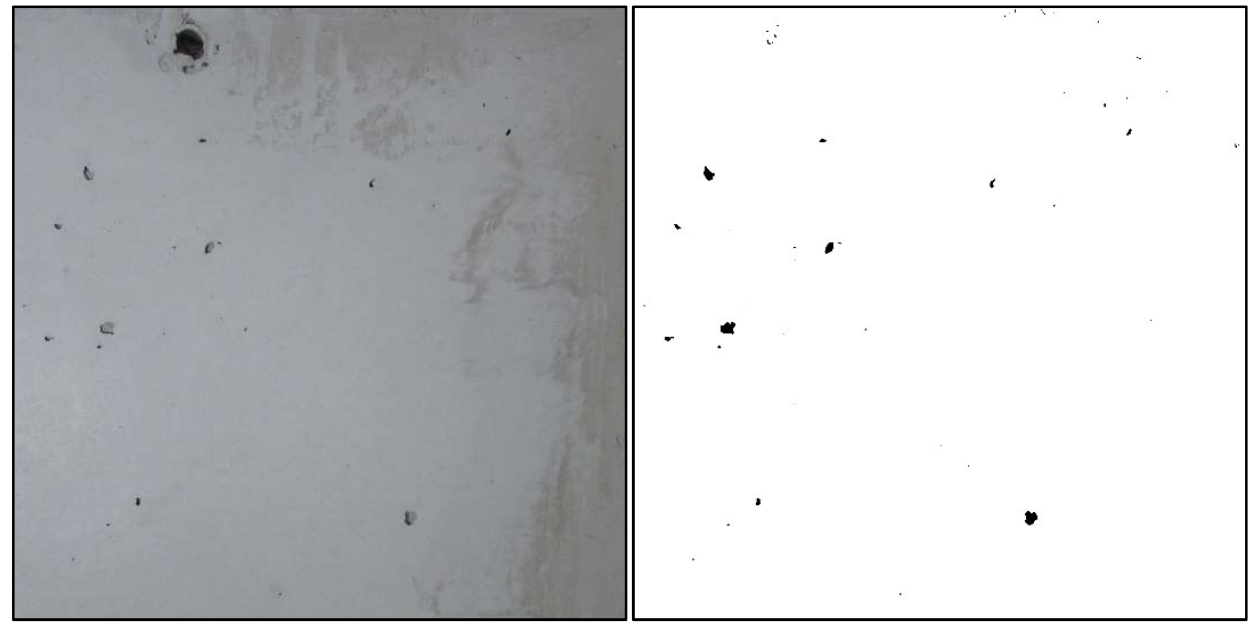

Fonte: Elaborada pelo autor. 
Figura 4.37 - Parede C40 9\%, Quadrante 3, Face Frontal - Falha: 0,229\%; Nota: 2,12.

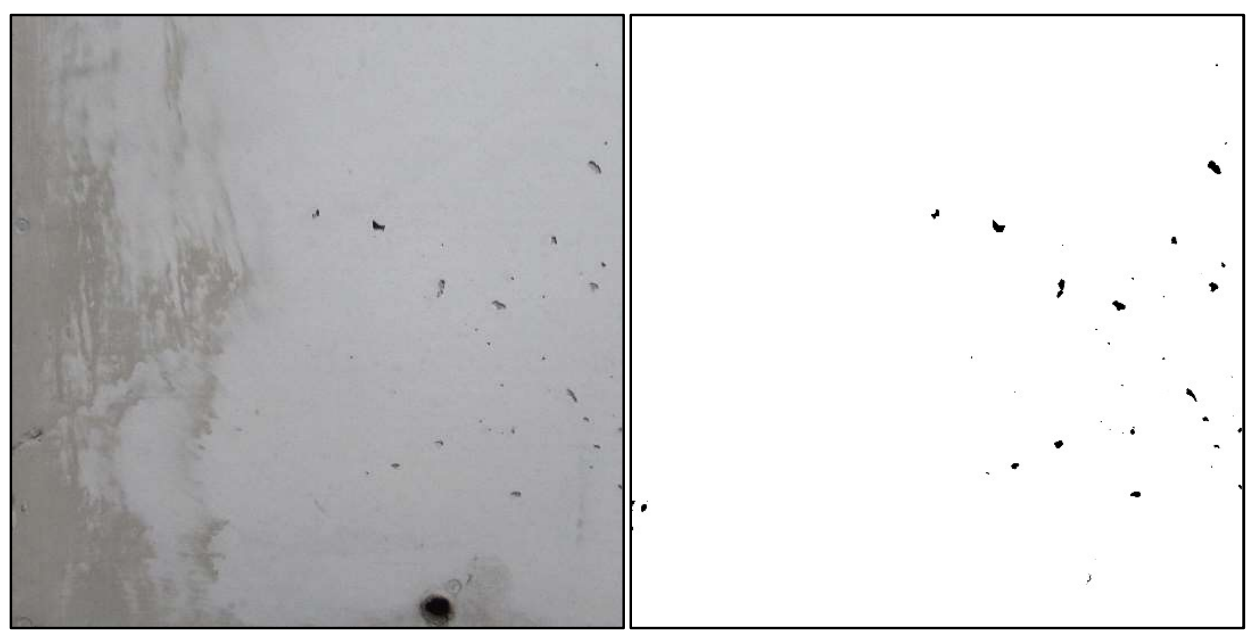

Fonte: Elaborada pelo autor.

Figura 4.38 - Parede C40 9\%, Quadrante 4, Face Frontal - Falha: 0,104\%; Nota: 1,33.

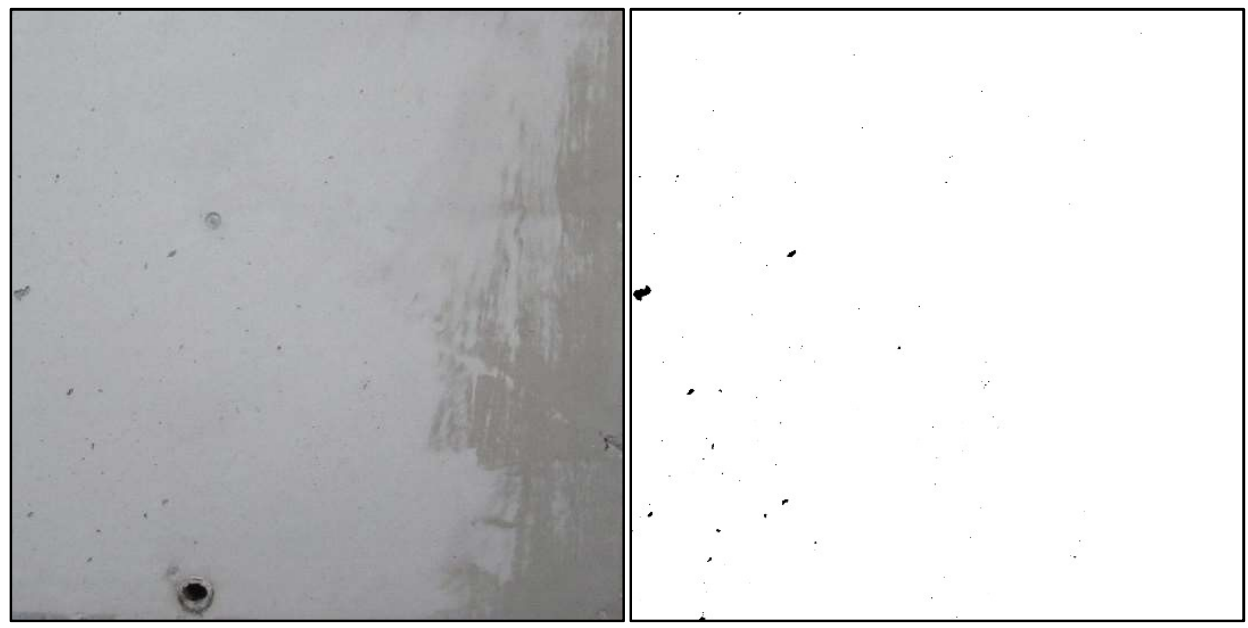

Fonte: Elaborada pelo autor.

Figura 4.39 - Parede C40 9\%, Quadrante 1, Face de Trás - Falha: 0,016\%; Nota: 1,00.

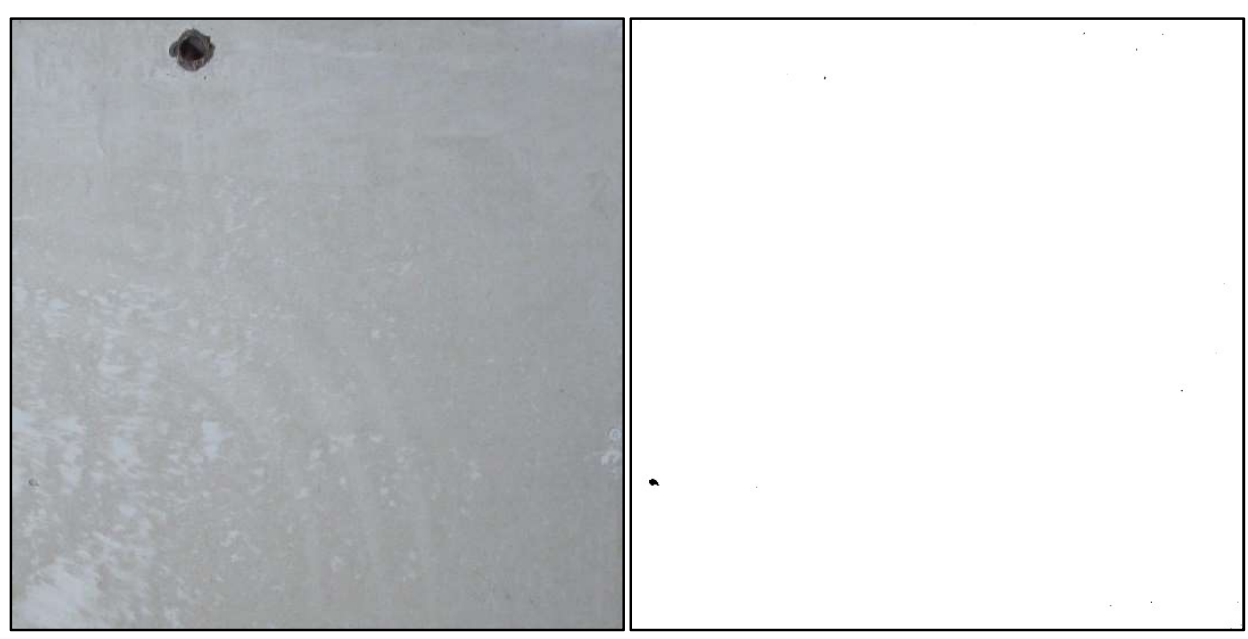

Fonte: Elaborada pelo autor. 
Figura 4.40 - Parede C40 9\%, Quadrante 2, Face de Trás - Falha: 0,007\%; Nota: 1,00.

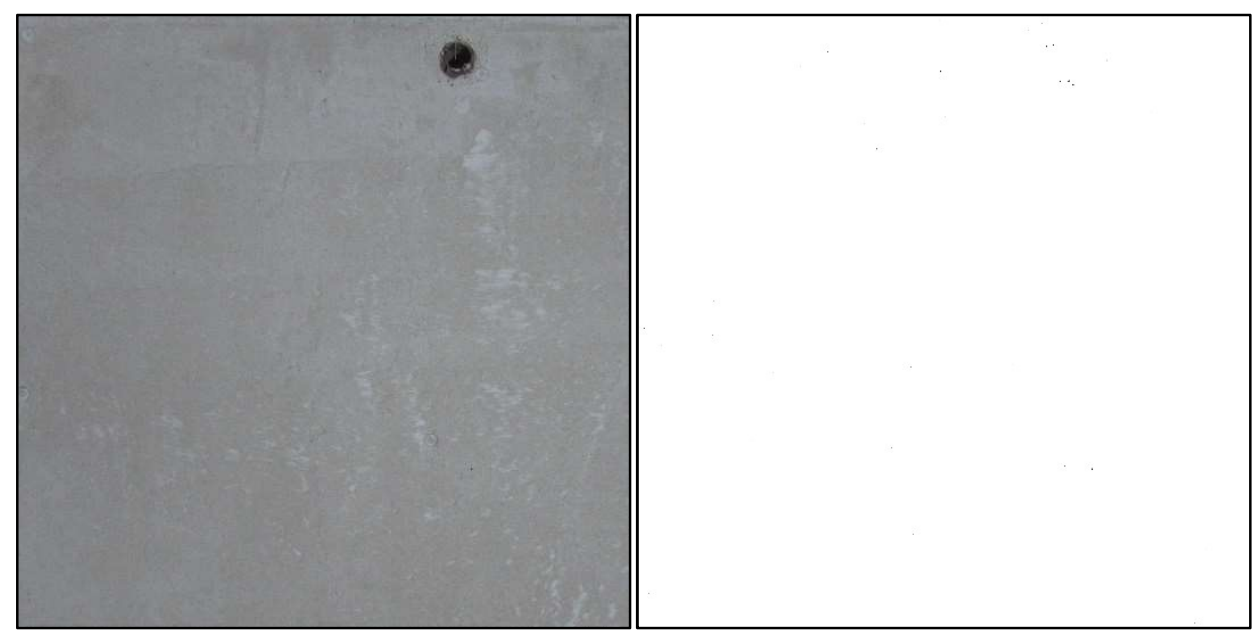

Fonte: Elaborada pelo autor.

Figura 4.41 - Parede C40 9\%, Quadrante 3, Face de Trás - Falha: 0,106\%; Nota: 1,34.

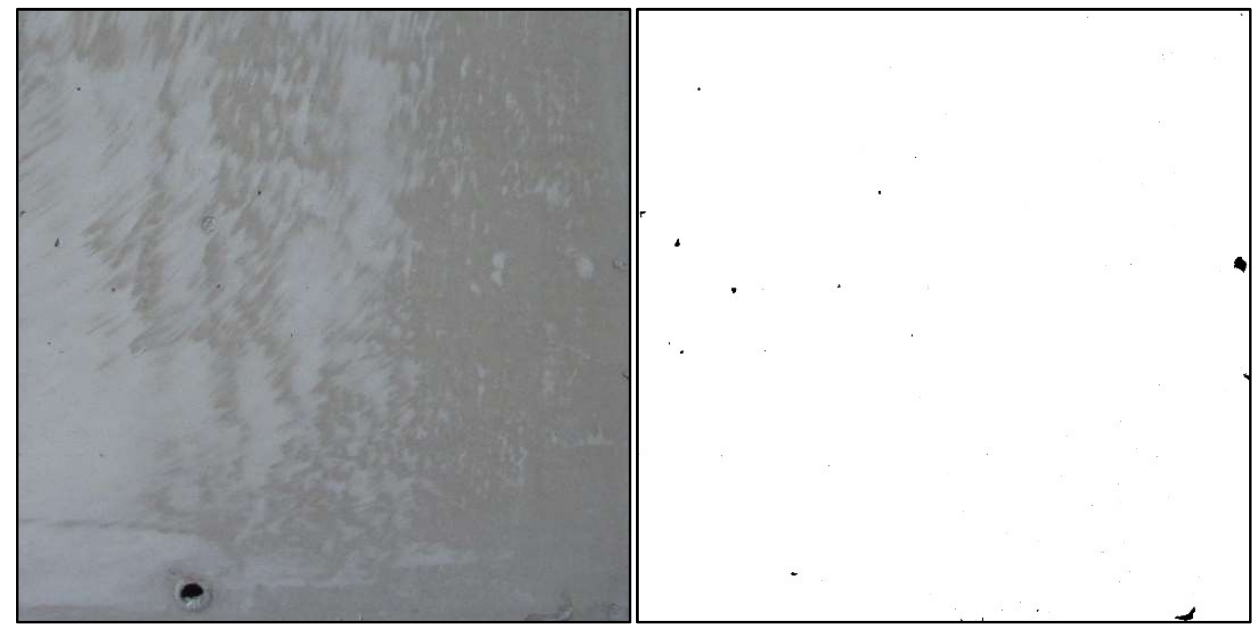

Fonte: Elaborada pelo autor.

Figura 4.42 - Parede C40 9\%, Quadrante 4, Face de Trás - Falha: 0,104\%; Nota: 1,33.

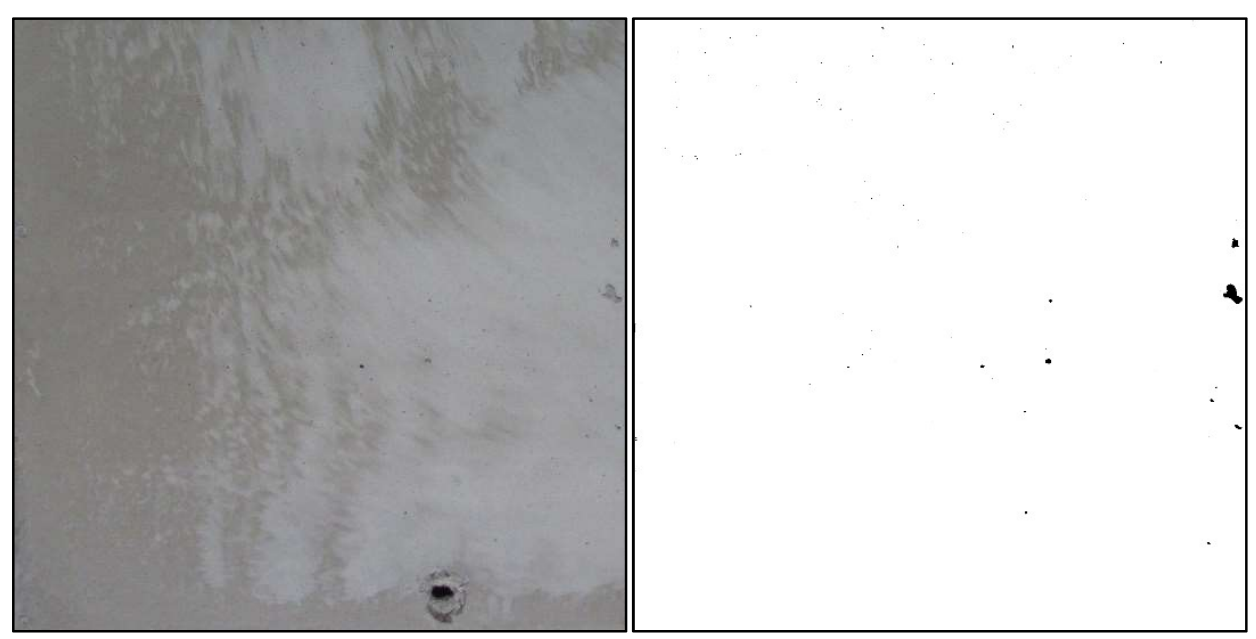

Fonte: Elaborada pelo autor. 
- Parede com concreto C40 15\%:

Figura 4.43 - Parede C40 15\%, Quadrante 1, Face Frontal - Falha: 0,082\%; Nota: 1,17.

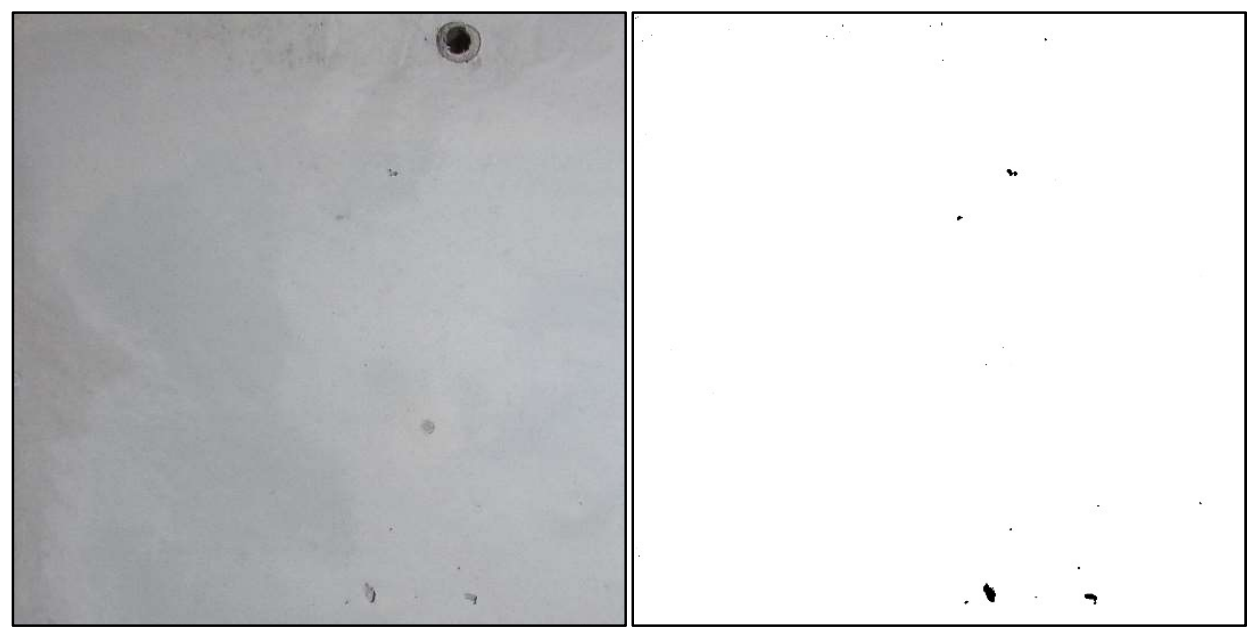

Fonte: Elaborada pelo autor.

Figura 4.44 - Parede C40 15\%, Quadrante 2, Face Frontal - Falha: 0,014\%; Nota: 1,00.

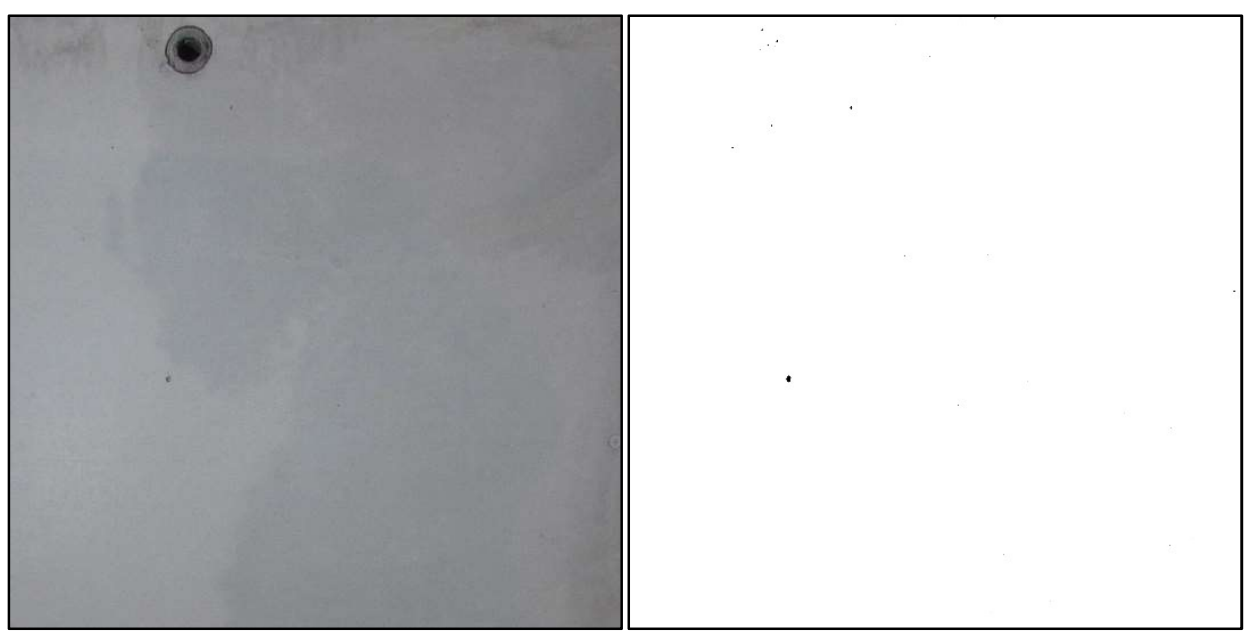

Fonte: Elaborada pelo autor. 
Figura 4.45 - Parede C40 15\%, Quadrante 3, Face Frontal - Falha: 0,198\%; Nota: 1,99.

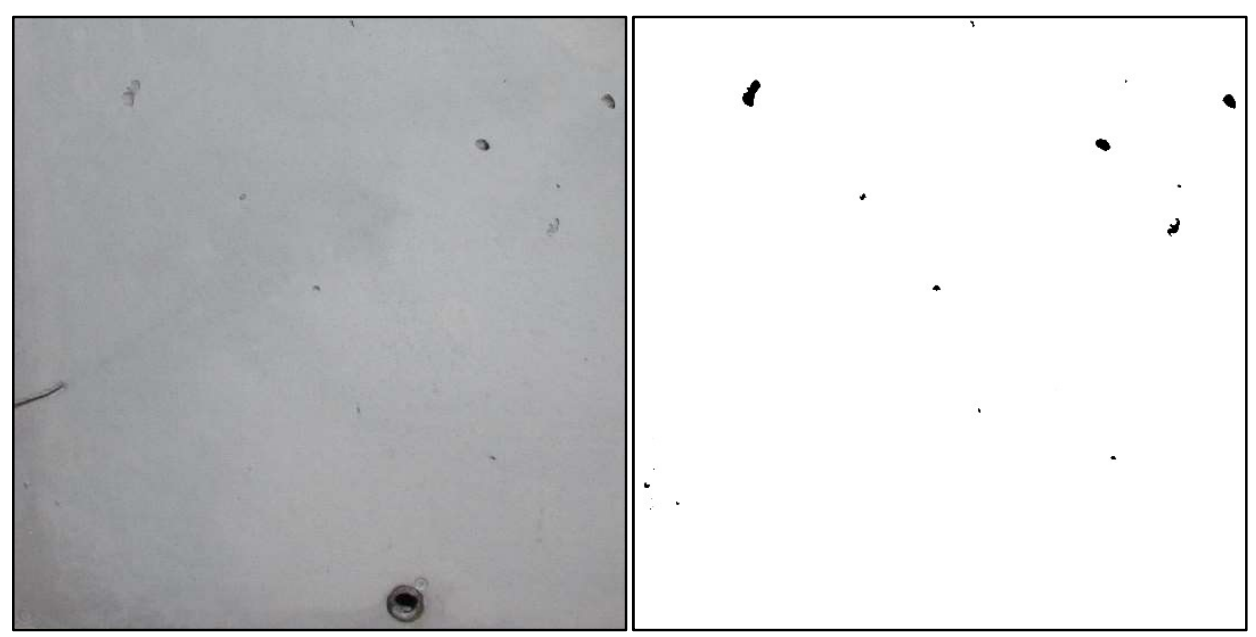

Fonte: Elaborada pelo autor.

Figura 4.46 - Parede C40 15\%, Quadrante 4, Face Frontal - Falha: 0,083\%; Nota: 1,18.

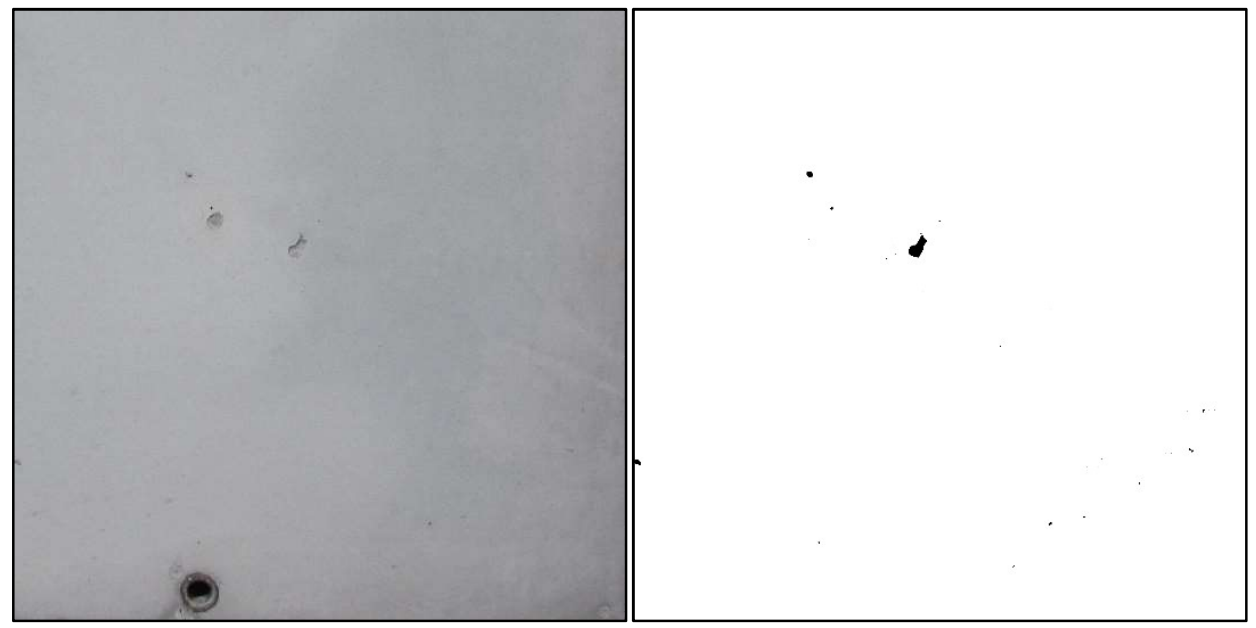

Fonte: Elaborada pelo autor.

Figura 4.47 - Parede C40 15\%, Quadrante 1, Face de Trás - Falha: 0,029\%; Nota: 1,00.

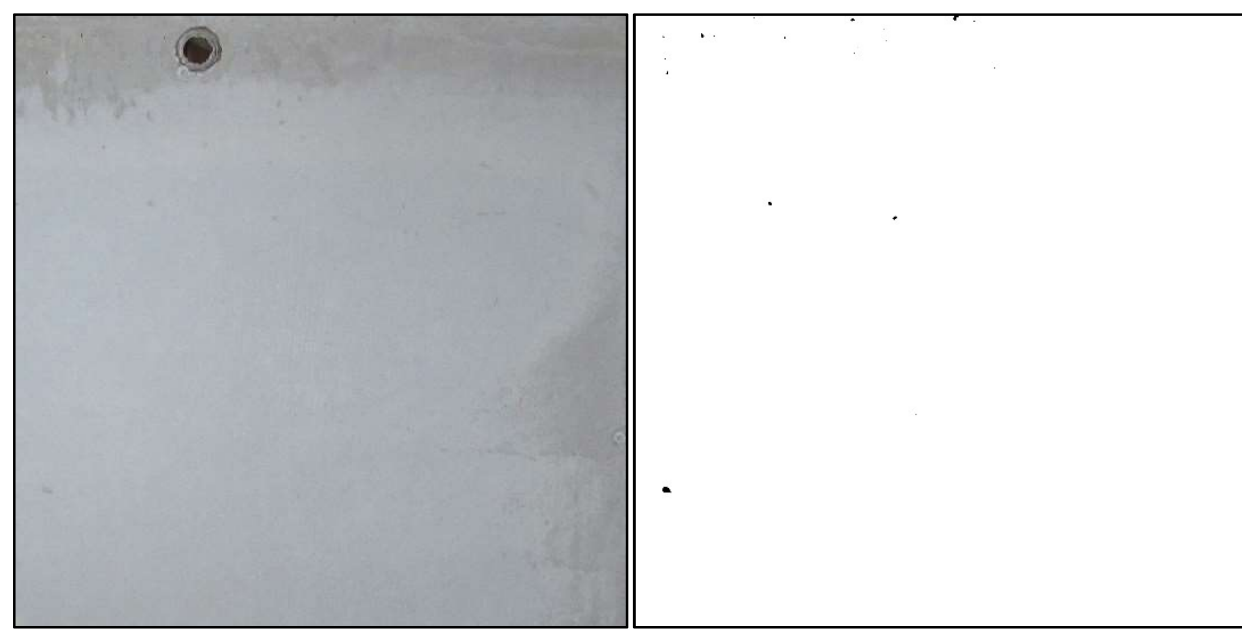

Fonte: Elaborada pelo autor. 
Figura 4.48 - Parede C40 15\%, Quadrante 2, Face de Trás - Falha: 0,012\%; Nota: 1,00.

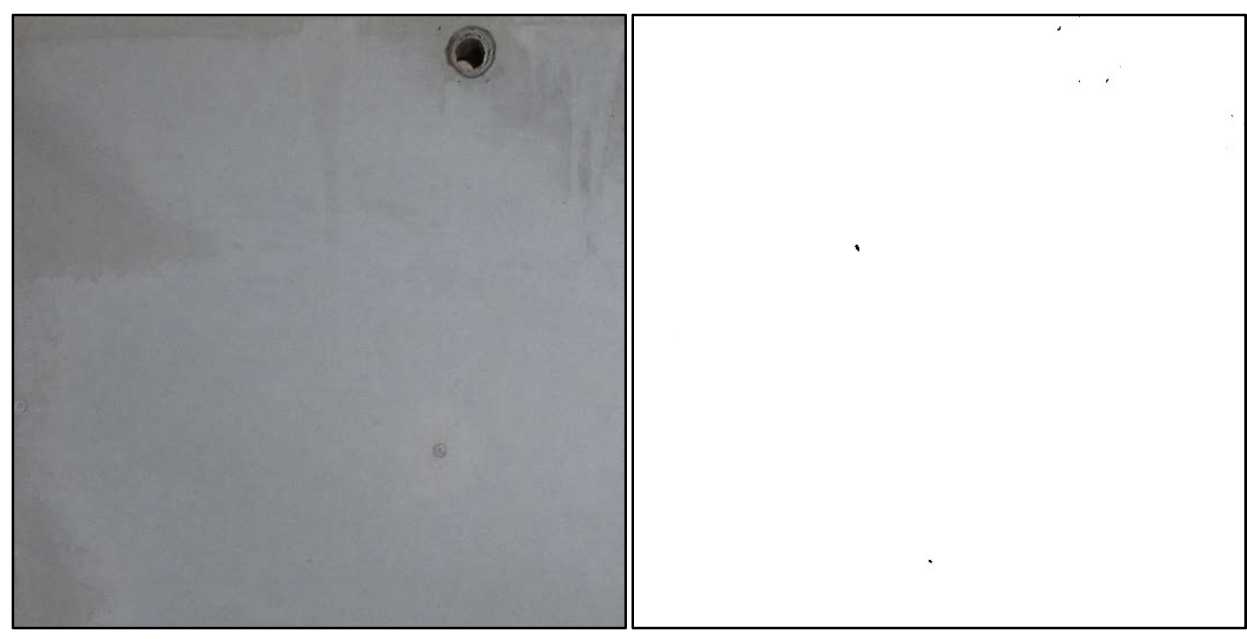

Fonte: Elaborada pelo autor.

Figura 4.49 - Parede C40 15\%, Quadrante 3, Face de Trás - Falha: 0,254\%; Nota: 2,22.

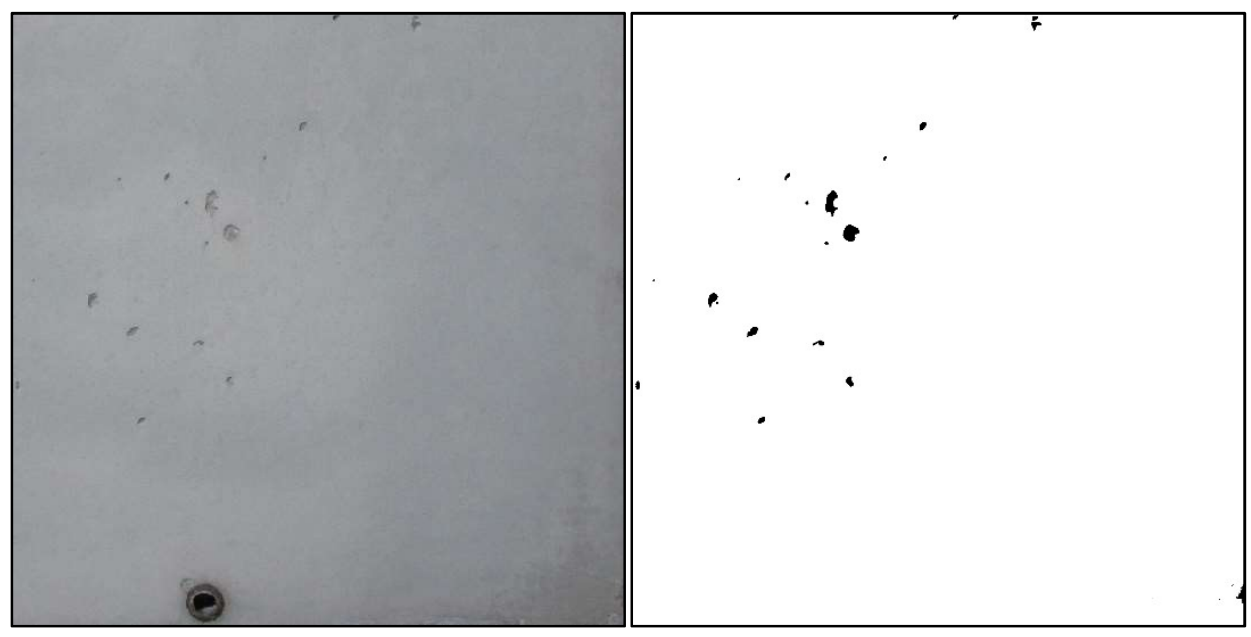

Fonte: Elaborada pelo autor.

Figura 4.50 - Parede C40 15\%, Quadrante 4, Face de Trás - Falha: 0,128\%; Nota: 1,50.

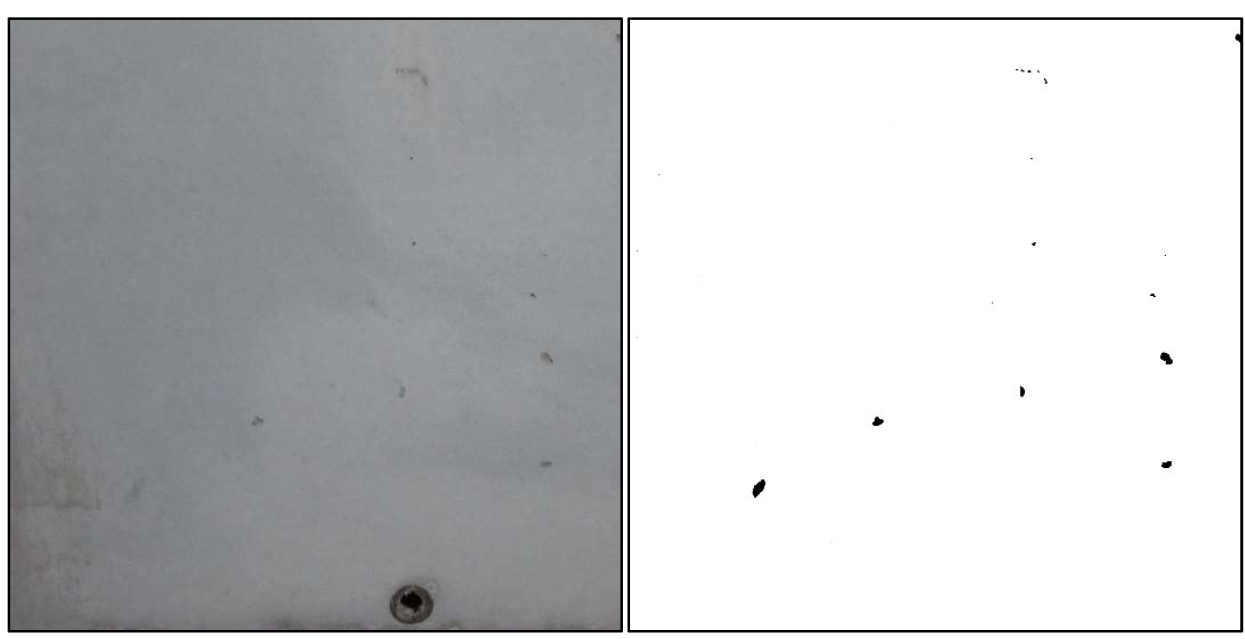

Fonte: Elaborada pelo autor. 
Os valores apresentados nas Figuras 4.27 a 4.50 para a falha superficial e a nota de acabamento foram compilados para os 3 traços de maneira a facilitar uma interpretação conjunta dos resultados. Os resultados estão apresentados nas Tabelas 4.43 a 4.45 .

Tabela 4.43 - Parede C40 referência - Resumo das notas de acabamento superficial.

\begin{tabular}{|c|c|c|c|c|c|c|c|}
\hline \multirow{2}{*}{\multicolumn{2}{|c|}{ Face }} & \multicolumn{4}{|c|}{ Quadrante } & \multirow{2}{*}{$\begin{array}{l}\text { Média por } \\
\text { Face }\end{array}$} & \multirow{2}{*}{$\begin{array}{l}\text { Nota Geral } \\
\text { da Parede }\end{array}$} \\
\hline & & 1 & 2 & 3 & 4 & & \\
\hline \multirow{2}{*}{ Frontal } & Falhas (\%) & 1,339 & 0,578 & 0,375 & 0,138 & 0,608 & \multirow{4}{*}{2,58} \\
\hline & Nota & 3,45 & 3,07 & 2,70 & 1,57 & 2,70 & \\
\hline \multirow{2}{*}{ De Trás } & Falhas (\%) & 1,116 & 0,779 & 0,194 & 0,115 & 0,551 & \\
\hline & Nota & 3,34 & 3,17 & 1,96 & 1,40 & 2,47 & \\
\hline
\end{tabular}

Tabela 4.44 - Parede C40 9\% - Resumo das notas de acabamento superficial.

\begin{tabular}{lccccccc}
\hline \multirow{2}{*}{ Face } & \multicolumn{4}{c}{ Quadrante } & Média por & $\begin{array}{c}\text { Nota Geral } \\
\text { Face } \\
\text { da Parede }\end{array}$ \\
\cline { 3 - 6 } Frontal & Falhas $(\%)$ & 0,120 & 0,171 & 0,229 & 0,104 & 0,156 & \\
& Nota & 1,44 & 1,80 & 2,12 & 1,33 & 1,67 & 1,42 \\
\multirow{2}{*}{ De Trás } & Falhas $(\%)$ & 0,016 & 0,007 & 0,106 & 0,104 & 0,058 & \\
& Nota & 1,00 & 1,00 & 1,34 & 1,33 & 1,17 & \\
& \multicolumn{5}{c}{ Fonte: Elaborada pelo autor. }
\end{tabular}

Fonte: Elaborada pelo autor.

Tabela 4.45 - Parede C40 15\% - Resumo das notas de acabamento superficial.

\begin{tabular}{lccccccc}
\hline \multirow{2}{*}{ Face } & \multicolumn{4}{c}{ Quadrante } & Média por & $\begin{array}{c}\text { Nota Geral } \\
\text { Face } \\
\text { da Parede }\end{array}$ \\
\cline { 3 - 6 } Frontal & Falhas (\%) & 0,082 & 0,014 & 0,198 & 0,083 & 0,094 & \\
& Nota & 1,17 & 1,00 & 1,99 & 1,18 & 1,34 & 1,38 \\
\multirow{2}{*}{ De Trás } & Falhas (\%) & 0,029 & 0,012 & 0,254 & 0,128 & 0,106 & \\
& Nota & 1,00 & 1,00 & 2,22 & 1,50 & 1,43 & \\
\hline
\end{tabular}

Fonte: Elaborada pelo autor.

A partir do exposto, podem ser feitas algumas observações. Uma delas é que a face de trás das paredes tende a apresentar um melhor acabamento superficial do que a face da frente. Isso provavelmente é decorrente do processo de concretagem, já que o concreto era lançado de carriolas posicionadas ao lado da face frontal em direção à face de trás, reduzindo o número de defeitos superficiais nesta. 
No caso da terceira parede, feita com o traço C40 15\%, o espalhamento foi o maior entre os valores obtidos para os traços empregados na execução das paredes, resultando em notas muito boas e praticamente iguais para as duas faces. Isso mostra que quanto maior for o espalhamento, menor será a interferência do processo de concretagem sobre o acabamento superficial do concreto.

O efeito do espalhamento é facilmente percebido ao se observar a nota geral de cada parede dada com base nas análises com software Image J. À medida que o espalhamento aumenta, a nota de acabamento diminui e, portanto, o acabamento superficial melhora.

Outra observação interessante é que, no caso da primeira parede, a nota dos quadrantes superiores nas duas faces é maior que nos quadrantes inferiores. Isso significa que o acabamento superficial do concreto está melhor nas regiões mais baixas da parede. Já no caso das outras duas paredes, essa situação se inverte, mostrando que o acabamento está melhor nas regiões mais altas.

Por fim, percebe-se que os traços propostos possuem alta capacidade de preenchimento, dado que não foi observada nenhuma falha de concretagem nas regiões críticas logo abaixo das janelas nas paredes produzidas. Dessa maneira, os cantos vivos induzidos com a consideração dos vazios centrais não representaram empecilhos para os concretos utilizados.

\subsubsection{Análise da estrutura interna}

A última etapa deste trabalho consiste na análise interna da estrutura das paredes concretadas com uso de aparelho de ultrassom. A obtenção dos tempos de transmissão do pulso ultrassônico ao longo do perímetro da parede nas seções consideradas se deu com base na metodologia apresentada no item 3.6 do presente trabalho.

As 5 medidas de tempo relacionadas a cada uma das 1144 posições entre transmissor e receptor foram inseridas no software em questão para análise de cada seção. $\mathrm{Na}$ sequência, o coeficiente de variação entre as medições de cada posição foi definido em no máximo $2 \%$. Dessa forma, o software apagou os valores mais discrepantes, fazendo com que o tempo médio utilizado na definição da velocidade se aproximasse mais do valor real.

Para o processamento e geração do mapa de velocidades ao longo da seção analisada, foi utilizado o método dos mínimos quadrados. O número de iterações consideradas para o método foi definido de tal forma que fosse possível a obtenção de velocidades mínima e máxima iguais a, respectivamente, $1000 \mathrm{~m} / \mathrm{s}$ e $7000 \mathrm{~m} / \mathrm{s}$, até que se respeitasse uma tolerância de $10^{-8}$ entre iterações consecutivas. 
Como visto nos ensaios anteriores, a velocidade do pulso ultrassônico no concreto é da ordem de $4000 \mathrm{~m} / \mathrm{s}$ até $4500 \mathrm{~m} / \mathrm{s}$. Assim, o limite inferior foi considerado como $1000 \mathrm{~m} / \mathrm{s}$ de maneira a evitar resultados negativos que não apresentam significado físico, enquanto o valor superior de $7000 \mathrm{~m} / \mathrm{s}$ foi adotado como uma extrapolação do valor máximo a ser observado.

Os ensaios foram feitos nas paredes 7 dias após a concretagem, sendo possível a comparação com os valores obtidos nos ensaios em prismas. Os resultados para as seções superior e inferior de cada parede estão apresentados e comentados na sequência.

- Parede com concreto C40 de referência, seção superior:

Figura 4.51 - Imagem tomográfica com distribuição de velocidades de pulso ultrassônico para concreto C40 de referência, seção superior.
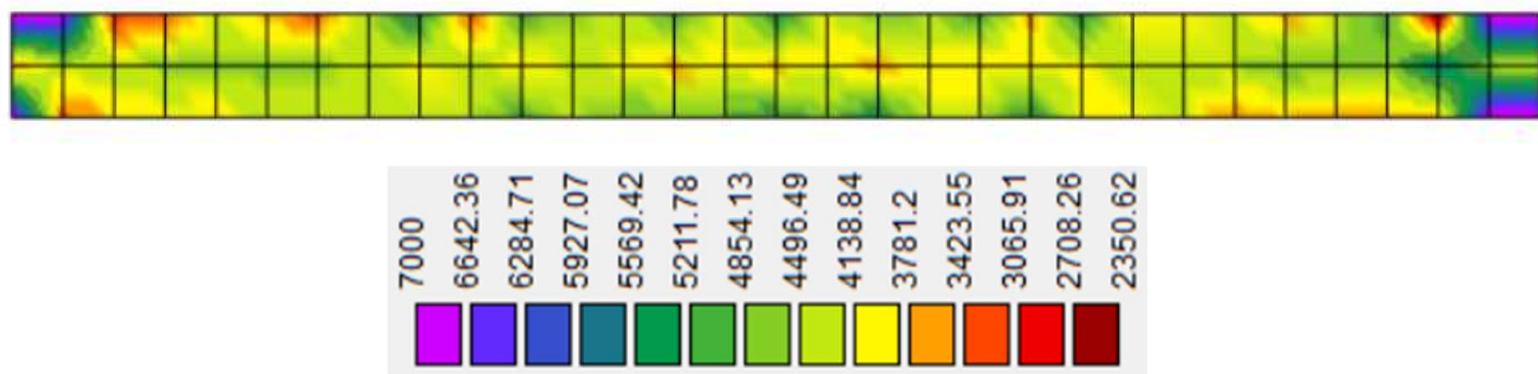

Fonte: Software TUSom.

Figura 4.52 - Comparação de velocidade teórica com experimental em função do comprimento de medição para concreto C40 de referência, seção superior.

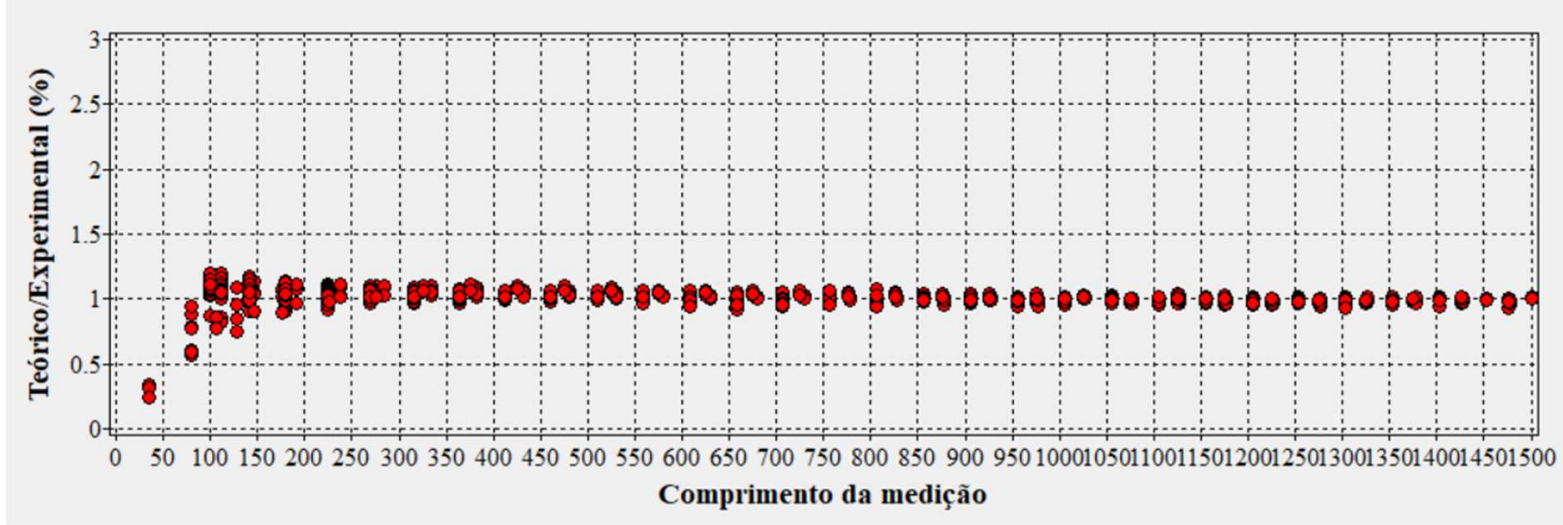

Fonte: Software TUSom. Comprimento em milímetros.

A Figura 4.51 consiste em um gráfico obtido com o software TUSom que apresenta uma relação de velocidade teórica por velocidade experimental para todas as medições em função de seu comprimento. A velocidade experimental é determinada em função das medições em laboratório, ou seja, o tempo medido é correlacionado com a distância entre os transdutores 
sendo determinada uma velocidade referente a esse posicionamento. Já a velocidade teórica é aquela definida de acordo com o processo de análise do software para cada medição.

Quanto mais próxima de 1 for a relação entre velocidade teórica e experimental, mais reais serão os resultados obtidos. Dessa forma, pode-se extrair da Figura 4.46 que as medições em geral ficaram muito boas, com exceção das medições para curta distância. Essa variação para distâncias de medição menores pode ser identificada na imagem tomográfica indicada na Figura 4.51 por meio dos maiores valores de velocidade obtidos nos cantos da parede. Os parâmetros fornecidos pelo software estão apresentados nas Tabelas 4.46 e 4.47.

Tabela 4.46 - Correlações entre velocidades teóricas e velocidades experimentais para concreto C40 de referência, seção superior.

\begin{tabular}{ccc}
\hline \multicolumn{3}{c}{ Medições } \\
\hline Média Teó./Exp. & CV (\%) [Teó./Exp.] & Coeficiente $\mathrm{R}^{2}$ \\
\hline 1,02 & 6,55 & 0,9978 \\
\hline & Fonte: Elaborada pelo autor.
\end{tabular}

Tabela 4.47 - Velocidades teóricas de interesse para concreto C40 de referência, seção superior.

\begin{tabular}{cccc}
\hline \multicolumn{3}{c}{ Velocidade (m/s) } \\
\hline Máxima & Mínima & Média & CV (\%) \\
\hline 7000 & 2350,62 & 4458,85 & 20,57 \\
\hline \multicolumn{3}{c}{ Fonte: Elaborada pelo autor. }
\end{tabular}

A Tabela 4.46 mostra um coeficiente $\mathrm{R}^{2}$ muito próximo de 1 , referente aos valores apresentados na Figura 4.51, sendo esse outro indicativo da qualidade das medições realizadas. Isso mostra que a imagem tomográfica gerada representa bem a estrutura interna real da seção analisada.

Em relação às velocidades obtidas, o valor de maior interesse é o de velocidade média. O valor de 4458,85 m/s corresponde a um concreto de boa qualidade, conforme Tabela 3.11. Esse valor pode ser comparado com o valor da velocidade média do pulso ultrassônico obtida para os prismas de concreto C40 de referência aos 7 dias, que foi de $4562,0 \mathrm{~m} / \mathrm{s}$. Podese observar que os valores são muito próximos, sendo a velocidade nos prismas um pouco maior. Dado que os traços utilizados foram os mesmos nos dois casos, entende-se que a estrutura interna dos prismas apresenta menor porosidade (SAINT-PIERRE et al., 2016). 
- Parede com concreto C40 de referência, seção inferior:

Figura 4.53 - Imagem tomográfica com distribuição de velocidades de pulso ultrassônico para concreto $\mathrm{C} 40$ de referência, seção inferior.
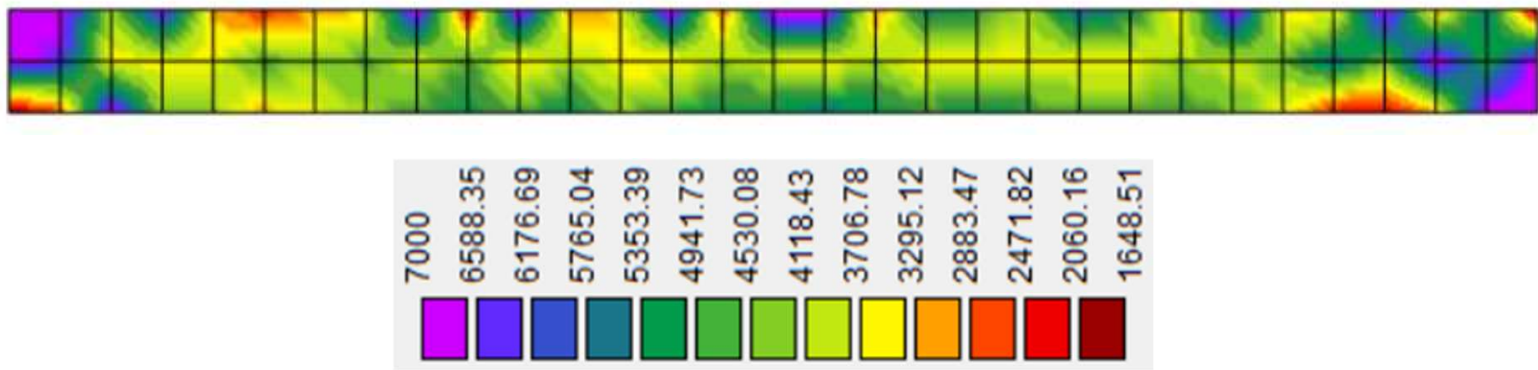

Fonte: Software TUSom.

Figura 4.54 - Comparação de velocidade teórica com experimental em função do comprimento de medição para concreto $\mathrm{C} 40$ de referência, seção inferior.

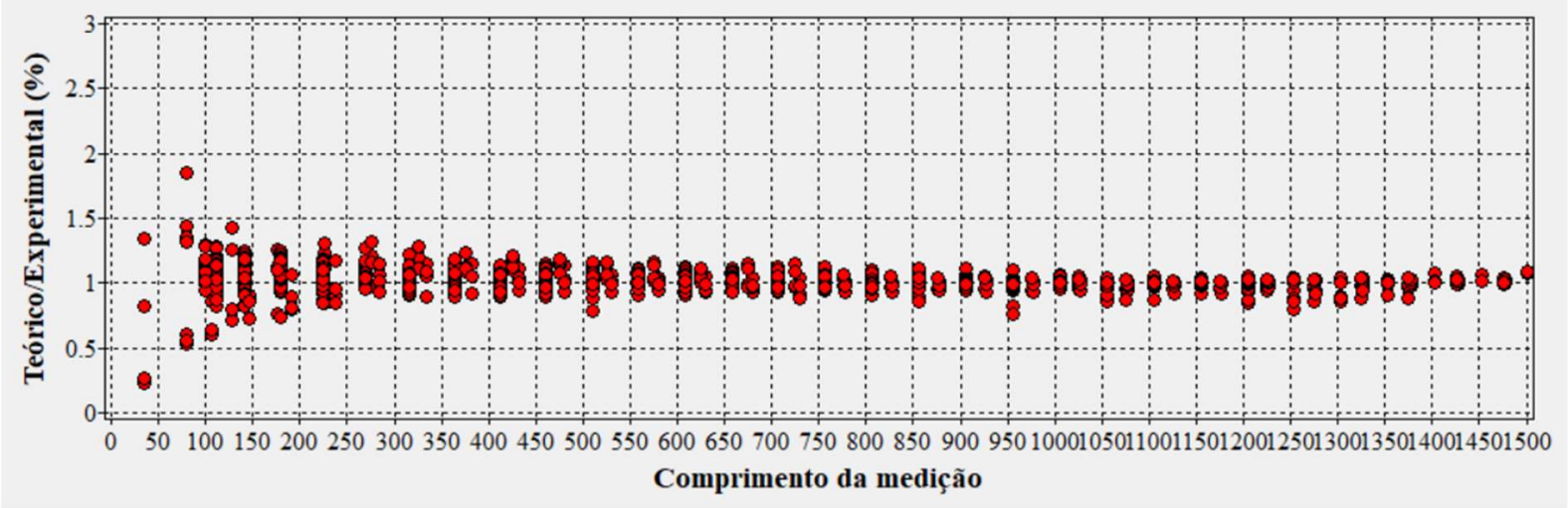

Fonte: Software TUSom. Comprimento em milímetros.

Para a seção inferior da parede com o concreto C40 referência, observa-se uma variação um pouco maior da relação velocidade teórica por velocidade experimental em comparação com a seção superior (Figuras 4.53 e 4.54). Esse fato pode ser explicado pela maior dificuldade envolvida com as medições em baixa altura, já que a posição dos operadores do equipamento fica prejudicada.

A maior variação dos dados apresentados na Figura 4.54 fica clara ao se observar um menor coeficiente $\mathrm{R}^{2}$ (Tabela 4.48). Ainda assim, seu valor também muito próximo de 1 é um indicativo da qualidade das medições. 
Tabela 4.48 - Correlações entre velocidades teóricas e velocidades experimentais para concreto C40 de referência, seção inferior.

\begin{tabular}{ccc}
\hline \multicolumn{3}{c}{ Medições } \\
\hline Média Teó./Exp. & CV (\%) [Teó./Exp.] & Coeficiente $\mathrm{R}^{2}$ \\
\hline 1,03 & 9,34 & 0,9889 \\
\hline & Fonte: Elaborada pelo autor.
\end{tabular}

Tabela 4.49 - Velocidades teóricas de interesse para concreto C40 de referência, seção inferior.

\begin{tabular}{cccc}
\hline \multicolumn{3}{c}{ Velocidade (m/s) } \\
\hline Máxima & Mínima & Média & CV (\%) \\
\hline 7000 & 1648,51 & 4522,79 & 31,72 \\
\hline \multicolumn{3}{c}{ Fonte: Elaborada pelo autor. }
\end{tabular}

A velocidade média teórica obtida para a seção inferior $(4522,79 \mathrm{~m} / \mathrm{s})$ apresenta valor novamente muito próximo ao observado nos prismas ensaiados para o concreto C40 referência aos 7 dias $(4562,0 \mathrm{~m} / \mathrm{s})$. O valor observado permite classificar o concreto com sendo de boa qualidade (Tabela 3.11).

Pode-se observar ainda, que a velocidade média do pulso ultrassônico para a seção inferior resultou $1,4 \%$ maior que na seção superior $(4458,85 \mathrm{~m} / \mathrm{s})$. Isso significa que a estrutura interna da seção inferior ficou melhor, apesar de a baixa variação obtida não deixar claro se a diferença de qualidade é efetiva. Ainda assim, os valores indicam que a sobrecarga exercida pelo concreto lançado acima da região inferior analisada apresenta um efeito positivo mais efetivo do que o efeito negativo causado pelo obstáculo existente (janela).

Os valores de velocidades médias para as seções consideradas podem também ser comparados com os resultados das análises de acabamento superficiais. No caso da parede feita com o C40 referência, os quadrantes superiores apresentaram nota média de 3,26 ao se considerar as duas faces, enquanto que os quadrantes inferiores receberam nota média de 1,91. Dessa forma, pode-se interpretar que a seção inferior ficou com melhor acabamento externo e com estrutura interna também melhor, quando em comparação com a seção superior. 
- Parede com concreto C40 9\%, seção superior:

Figura 4.55 - Imagem tomográfica com distribuição de velocidades de pulso ultrassônico para concreto C40 9\%, seção superior.
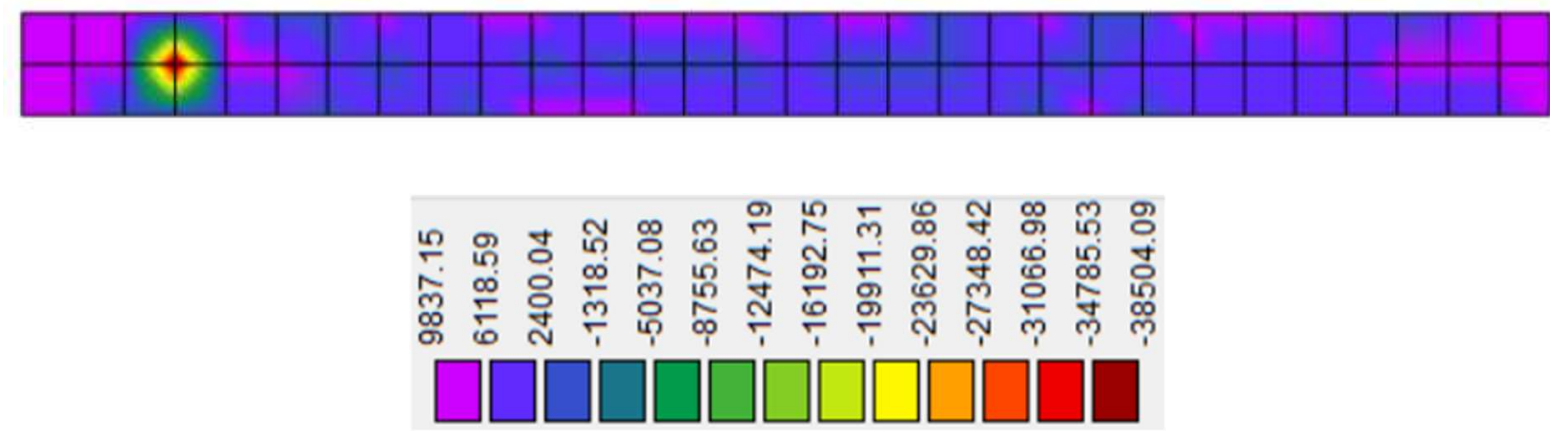

Fonte: Software TUSom.

Figura 4.56 - Comparação de velocidade teórica com experimental em função do comprimento de medição para concreto C40 9\%, seção superior.

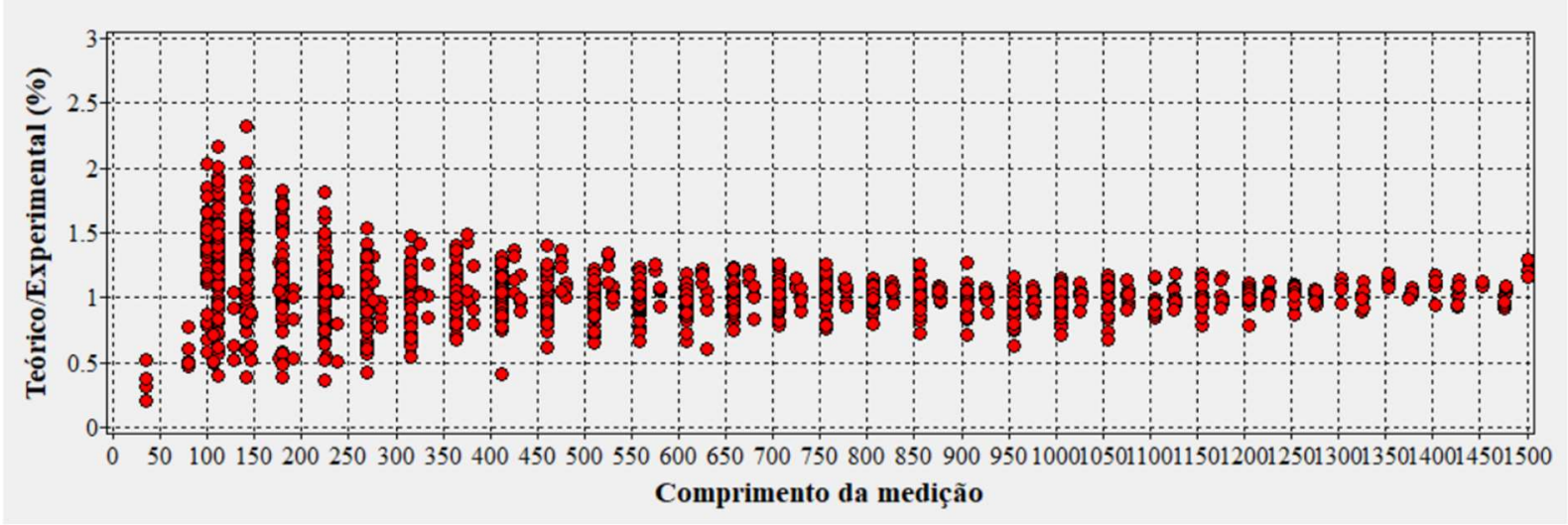

Fonte: Software TUSom. Comprimento em milímetros.

A partir do gráfico apresentado na Figura 4.56, pode-se observar que as medições não ficaram muito precisas. Isso porque existe uma grande variação dos valores teóricos e experimentais, de forma que o resultado pode acabar não representando muito bem o que acontece na realidade. Entende-se que isso pode ter ocorrido pelo fato de todas as medições terem sido feitas por apenas 2 operadores ao longo de todo o dia, sem ocorrer revezamento com mais pessoas como feito no primeiro modelo da parede. O valor do coeficiente $\mathrm{R}^{2}$ (Tabela 4.50 ) demonstra essa relativa imprecisão das medições. 
Tabela 4.50 - Correlações entre velocidades teóricas e velocidades experimentais para concreto C40 $9 \%$, seção superior.

\begin{tabular}{ccc}
\hline \multicolumn{3}{c}{ Medições } \\
\hline Média Teó./Exp. & $\mathrm{CV}(\%)[$ Teó./Exp.] & Coeficiente $\mathrm{R}^{2}$ \\
\hline 1,05 & 23,06 & 0,9502 \\
\hline & Fonte: Elaborada pelo autor.
\end{tabular}

O problema entre a relação teórico/experimental se reflete nos valores de velocidade obtidos, como pode ser observado na Tabela 4.51 .

Tabela 4.51 - Velocidades teóricas de interesse para concreto C40 9\%, seção superior.

\begin{tabular}{cccc}
\hline \multicolumn{4}{c}{ Velocidade (m/s) } \\
\hline Máxima & Mínima & Média & CV (\%) \\
\hline 9837,15 & $-38504,09$ & 4024,61 & 123,25 \\
\hline \multicolumn{3}{c}{ Fonte: Elaborada pelo autor. }
\end{tabular}

Como as velocidades máxima e mínima se encontram fora do intervalo determinado anteriormente, o método dos mínimos quadrados não encontrou solução para o problema. Durante a análise dos resultados, foram identificados os dois pontos que apresentavam velocidade fora do intervalo de interesse. A velocidade de cada um foi corrigida manualmente, forçando o ponto com velocidade de $9837,15 \mathrm{~m} / \mathrm{s}$ a possuir valor de $7000 \mathrm{~m} / \mathrm{s}$ e o ponto com velocidade negativa a apresentar $1000 \mathrm{~m} / \mathrm{s}$.

A imagem tomográfica foi então gerada novamente (Figura 4.57), juntamente ao gráfico (Figura 4.58) e valores de interesse (Tabelas 4.52 e 4.53). Os resultados estão apresentados na sequência.

Figura 4.57 - Imagem tomográfica atualizada com distribuição de velocidades de pulso ultrassônico para concreto C40 9\%, seção superior.
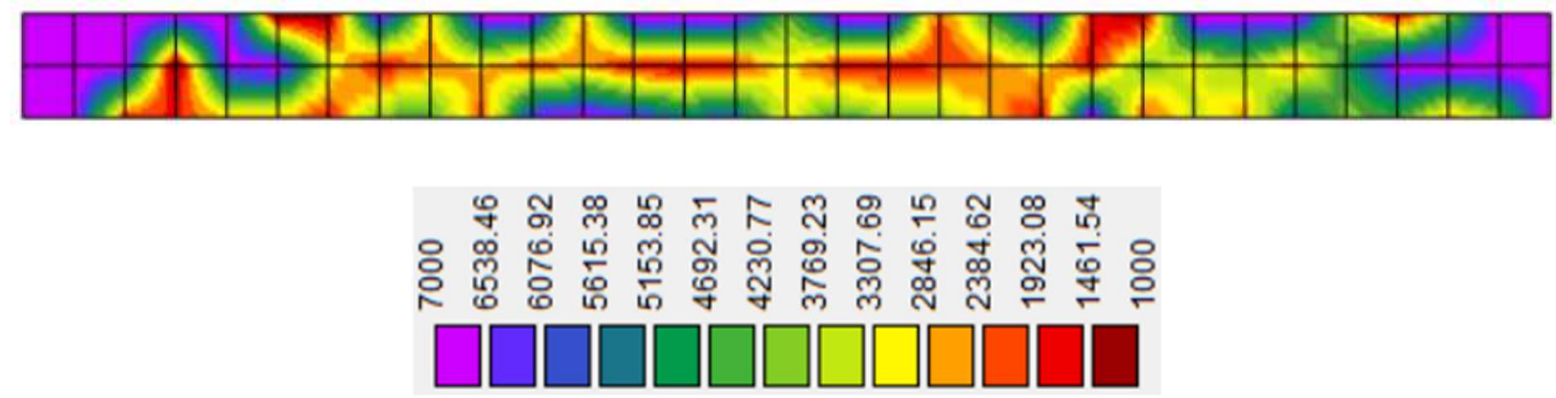

Fonte: Software TUSom. 
Figura 4.58 - Comparação atualizada de velocidade teórica com experimental em função do comprimento de medição para concreto C40 9\%, seção superior.

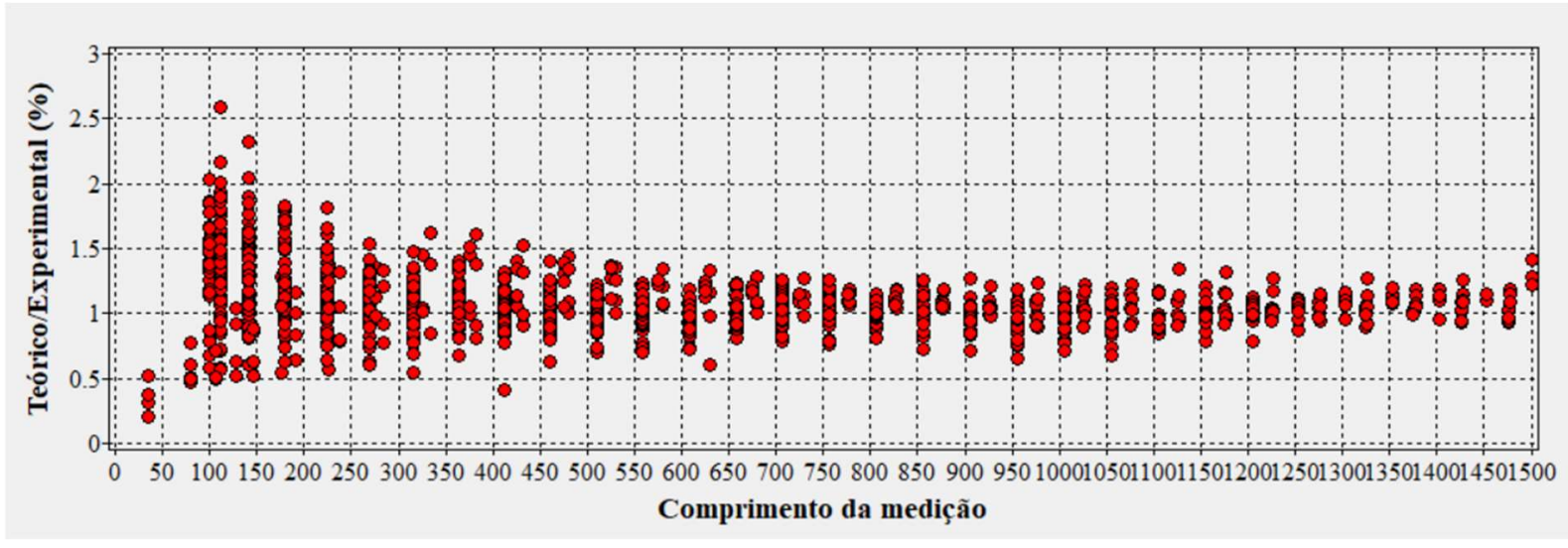

Fonte: Software TUSom. Comprimento em milímetros.

Tabela 4.52 - Correlações atualizadas entre velocidades teóricas e velocidades experimentais para concreto C40 9\%, seção superior.

\begin{tabular}{ccc}
\hline \multicolumn{3}{c}{ Medições } \\
\hline Média Teó./Exp. & CV (\%) [Teó./Exp.] & Coeficiente R ${ }^{2}$ \\
\hline 1,09 & 22,47 & 0,9431 \\
\hline & Fonte: Elaborada pelo autor.
\end{tabular}

Pode-se perceber que a mudança realizada praticamente não causou efeito no gráfico da Figura 4.58. O coeficiente $\mathrm{R}^{2}$ inclusive passou a apresentar valor inferior ao obtido anteriormente. Porém, com a correção das velocidades, assume-se que o valor médio obtido, de $4418,88 \mathrm{~m} / \mathrm{s}$, é mais próximo da realidade (Tabela 4.53).

Tabela 4.53 - Velocidades teóricas de interesse atualizadas para concreto C40 9\%, seção superior.

\begin{tabular}{cccc}
\hline \multicolumn{3}{c}{ Velocidade (m/s) } \\
\hline Máxima & Mínima & Média & CV (\%) \\
\hline 7000 & 1000 & 4418,88 & 49,75 \\
\hline \multicolumn{3}{c}{ Fonte: Elaborada pelo autor. }
\end{tabular}

A velocidade média pode ser comparada com os valores obtidos nos ensaios dos prismas de C40 9\% aos 7 dias. No caso dos prismas, as velocidades médias nas direções longitudinal e transversal apresentam valores com diferença significativa de acordo com teste $t$ presente em apêndice. Dessa maneira, não é adequada a comparação com a média desses valores, mas sim com os valores individuais. 
A velocidade transversal média nos prismas foi de $4312,8 \mathrm{~m} / \mathrm{s}$, enquanto que a longitudinal média foi de 4063,7 m/s. Nos dois casos, a velocidade observada é menor do que a obtida na seção superior da parede. Porém, o valor obtido $(4418,88 \mathrm{~m} / \mathrm{s})$ está dentro do intervalo previsto, conforme dados apresentados anteriormente. Desconsiderando os possíveis problemas relacionados às medições, o concreto em análise pode ser caracterizado com boa qualidade (Tabela 3.11).

Em comparação com a velocidade observada na seção superior da parede com C40 de referência $(4458,85 \mathrm{~m} / \mathrm{s})$, observa-se pequena queda na velocidade na seção aqui verificada. Esse fato pode ser justificado pela maior porosidade resultante da incorporação de ar no concreto.

- Parede com concreto C40 9\%, seção inferior:

Figura 4.59 - Imagem tomográfica com distribuição de velocidades de pulso ultrassônico para concreto C40 9\%, seção inferior.
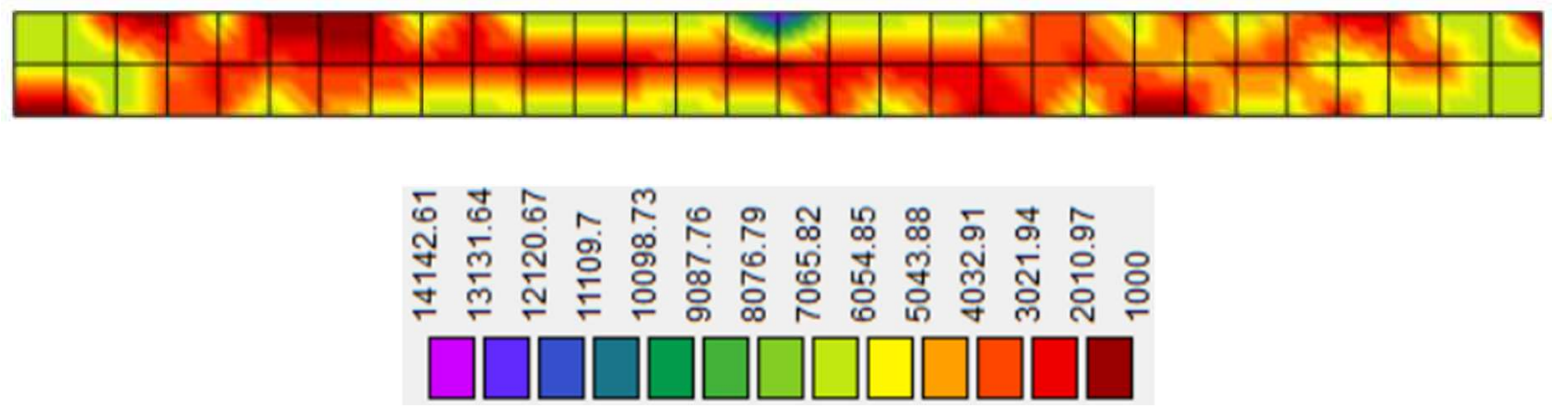

Fonte: Software TUSom.

Figura 4.60 - Comparação de velocidade teórica com experimental em função do comprimento de medição para concreto C40 9\%, seção inferior.

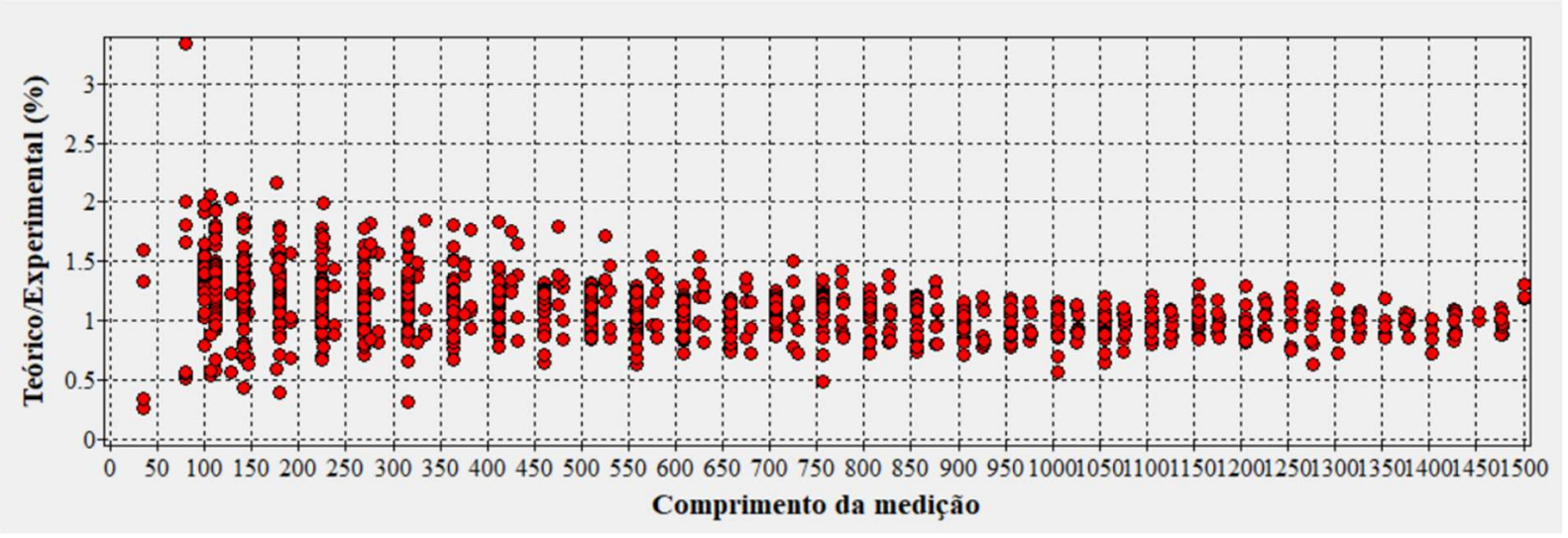

Fonte: Software TUSom. Comprimento em milímetros. 
Assim como no caso da seção superior, a seção inferior da parede com concreto C40 9\% apresentou grande variação na relação velocidade teórica/experimental (Figuras 4.59 e 4.60, e Tabela 4.54).

Tabela 4.54 - Correlações entre velocidades teóricas e velocidades experimentais para concreto C40 $9 \%$, seção inferior.

\begin{tabular}{ccc}
\hline \multicolumn{3}{c}{ Medições } \\
\hline Média Teó./Exp. & CV (\%) [Teó./Exp.] & Coeficiente $\mathrm{R}^{2}$ \\
\hline 1,13 & 22,43 & 0,923 \\
\hline
\end{tabular}

Fonte: Elaborada pelo autor.

Da mesma maneira que observado na parede C40 de referência, as medições na seção superior apresentaram resultado melhor que na seção inferior. Isso fica claro ao se comparar os valores do coeficiente $\mathrm{R}^{2}$ em cada caso.

Tabela 4.55 - Velocidades teóricas de interesse para concreto C40 9\%, seção inferior.

\begin{tabular}{cccc}
\hline \multicolumn{3}{c}{ Velocidade (m/s) } \\
\hline Máxima & Mínima & Média & CV (\%) \\
\hline 14142,61 & 1000 & 4663,14 & 54,26 \\
\hline \multicolumn{3}{c}{ Fonte: Elaborada pelo autor. }
\end{tabular}

Em termos de velocidades, novamente é observado um valor fora dos limites estabelecidos (Tabela 4.55), indicando que o método dos mínimos quadrados não encontrou solução para as restrições impostas. Identificou-se o ponto com a velocidade de $14142,61 \mathrm{~m} / \mathrm{s}$ e forçou-se seu valor para $7000 \mathrm{~m} / \mathrm{s}$. Os resultados estão apresentados na sequência (Figuras 4.61 e 4.62 , e Tabelas 4.56 e 4.57).

Figura 4.61 - Imagem tomográfica atualizada com distribuição de velocidades de pulso ultrassônico para concreto C40 9\%, seção inferior.
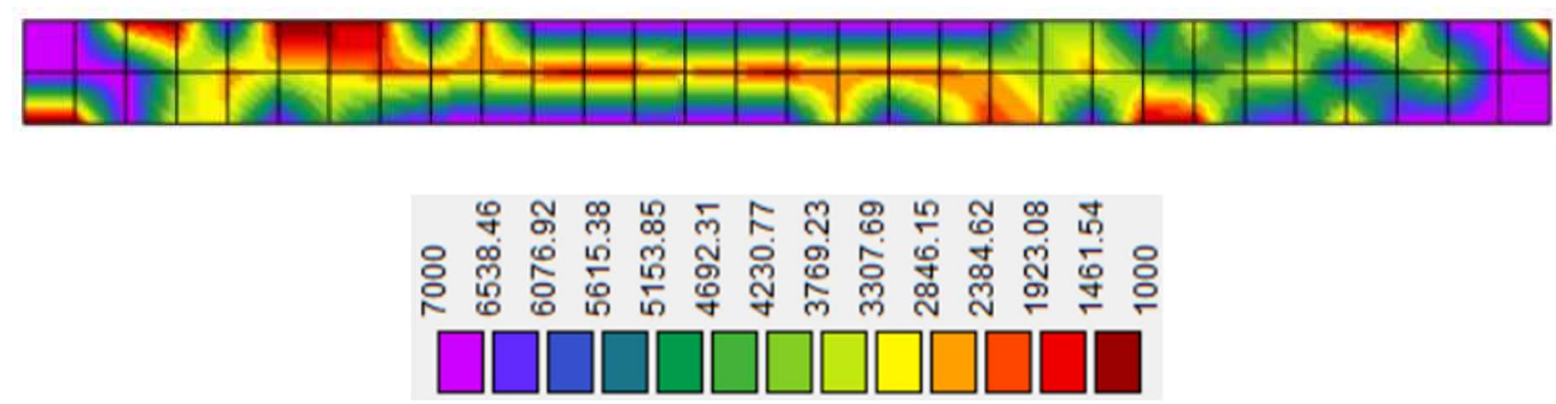

Fonte: Software TUSom. 
Figura 4.62 - Comparação atualizada de velocidade teórica com experimental em função do comprimento de medição para concreto C40 9\%, seção inferior.

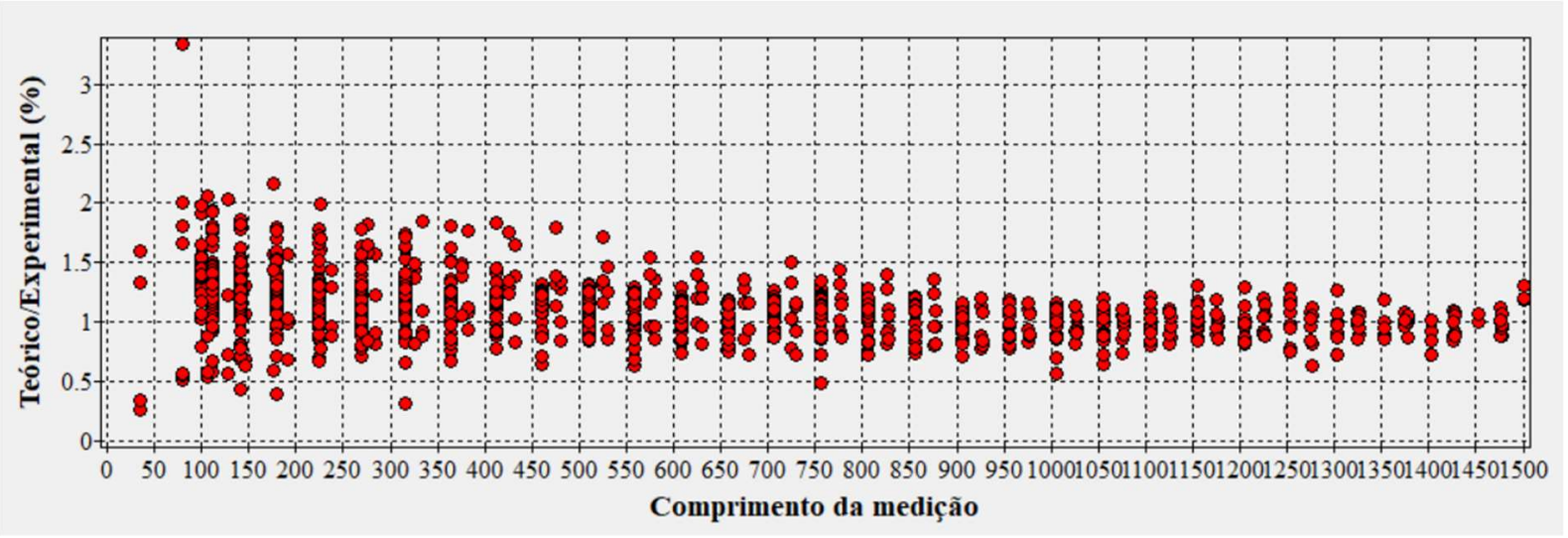

Fonte: Software TUSom. Comprimento em milímetros.

Tabela 4.56 - Correlações atualizadas entre velocidades teóricas e velocidades experimentais para concreto C40 9\%, seção inferior.

\begin{tabular}{ccc}
\hline \multicolumn{3}{c}{ Medições } \\
\hline Média Teó./Exp. & CV (\%) [Teó./Exp.] & Coeficiente $\mathrm{R}^{2}$ \\
\hline 1,13 & 22,37 & 0,9229 \\
\hline \multicolumn{3}{c}{ Fonte: Elaborada pelo autor. }
\end{tabular}

Como observado anteriormente, a alteração da velocidade em determinado ponto não afeta muito os parâmetros gerais das medições. Neste caso, o coeficiente $\mathrm{R}^{2}$ praticamente não foi alterado comparando as duas situações.

Tabela 4.57 - Velocidades teóricas de interesse atualizadas para concreto C40 9\%, seção inferior.

\begin{tabular}{cccc}
\hline \multicolumn{4}{c}{ Velocidade (m/s) } \\
\hline Máxima & Mínima & Média & CV (\%) \\
\hline 7000 & 1000 & 4586,34 & 51,08 \\
\hline \multicolumn{3}{c}{ Fonte: Elaborada pelo autor. }
\end{tabular}

A mudança maior acontece na velocidade média, que apresentava um valor inicial de $4663,14 \mathrm{~m} / \mathrm{s}$ e passou a ser de $4586,34 \mathrm{~m} / \mathrm{s}$ (Tabela 4.57). Porém, mesmo com o ajuste feito, o valor obtido continuou elevado. Isso pode ser afirmado porque, em comparação com a velocidade na seção inferior da parede C40 de referência $(4522,79 \mathrm{~m} / \mathrm{s})$, houve aumento na velocidade. Esperava-se que a velocidade diminuísse com o aumento da porosidade.

Esse aumento de velocidade em comparação com o traço de referência é mais um indício de que as medições para a parede com concreto C40 9\% não ficaram muito precisas. 
Ainda assim, a média de velocidade se encontra dentro do intervalo esperado para o concreto. Segundo Tabela 3.11, essa velocidade caracteriza o concreto com excelente qualidade.

Em relação aos valores das velocidades transversal $(4312,8 \mathrm{~m} / \mathrm{s})$ e longitudinal (4067,3 m/s) nos prismas, a velocidade de 4586,34 m/s aqui obtida apresenta valor bem elevado.

A comparação com a velocidade na seção superior da mesma parede $(4418,88 \mathrm{~m} / \mathrm{s})$ também é válida. Novamente se observa um aumento da velocidade do pulso ultrassônico $(3,8 \%)$. Novamente, esse aumento é muito pequeno para se afirmar que a diferença observada representa efetivamente uma melhor qualidade na seção inferior. Ainda assim, considerandose os valores obtidos, pode-se interpretar que o resultado destoa do observado para o acabamento superficial, onde os quadrantes superiores apresentaram nota média de 1,31 enquanto que os quadrantes inferiores obtiveram nota média de 1,53. Isso mostra que o acabamento superficial não necessariamente reflete a qualidade da estrutura interna do concreto.

- Parede com concreto C40 15\%, seção superior:

Figura 4.63 - Imagem tomográfica com distribuição de velocidades de pulso ultrassônico para concreto C40 15\%, seção superior.
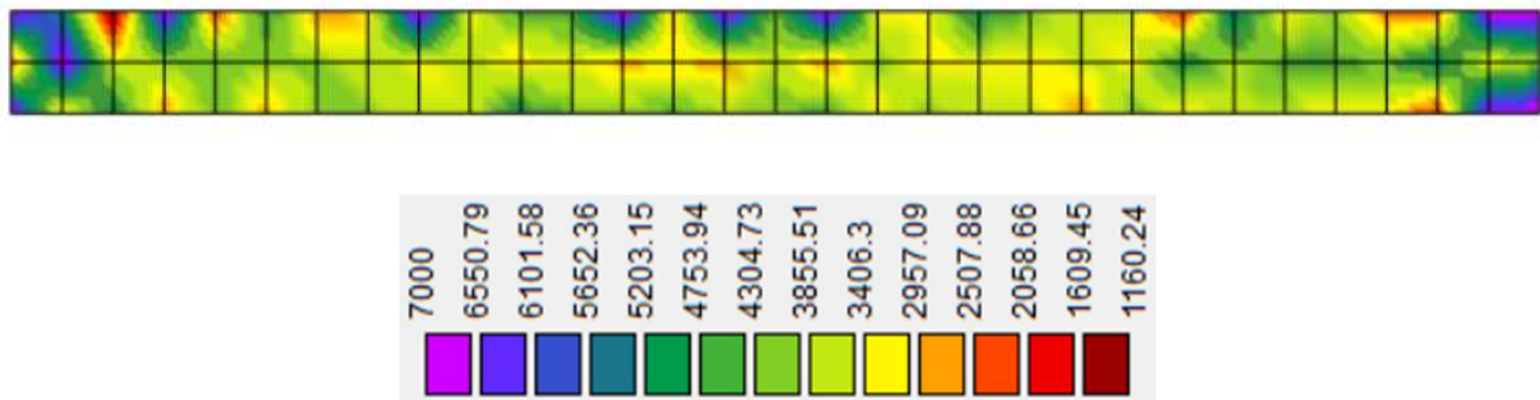

Fonte: Software TUSom. 
Figura 4.64 - Comparação de velocidade teórica com experimental em função do comprimento de medição para concreto C40 15\%, seção superior.

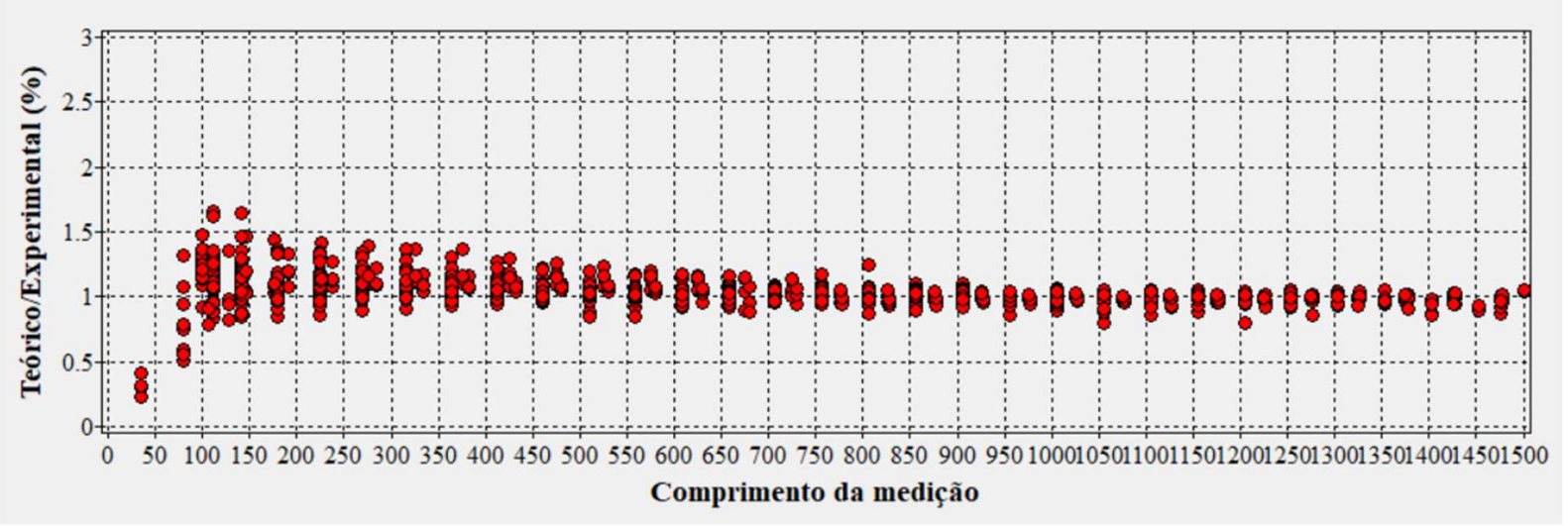

Fonte: Software TUSom. Comprimento em milímetros.

A partir da Figura 4.64, observa-se que os resultados para a parede C40 15\% se aproximam mais da parede C40 de referência do que da parede C40 9\%. Isso indica que a incorporação de ar não foi a principal responsável pela baixa qualidade dos resultados na segunda parede analisada, mas sim algo relacionado ao processo de medição propriamente dito.

O gráfico obtido para a distribuição de velocidade teórica/experimental em função do comprimento de medição mostra novamente que essa relação se aproxima mais de 1 a medida que a distância entre os transdutores aumenta (Figura 4.64). No caso de medições muito próximas (até cerca de $35 \mathrm{~cm}$ ), há uma dispersão maior dos valores em questão.

Tabela 4.58 - Correlações entre velocidades teóricas e velocidades experimentais para concreto C40 $15 \%$, seção superior.

\begin{tabular}{ccc}
\hline \multicolumn{3}{c}{ Medições } \\
\hline Média Teó./Exp. & CV (\%) [Teó./Exp.] & Coeficiente R ${ }^{2}$ \\
\hline 1,06 & 10,69 & 0,9894 \\
\hline & Fonte: Elaborada pelo autor.
\end{tabular}

O coeficiente $\mathrm{R}^{2}$ obtido para o gráfico da Figura 4.64 apresenta valor bem próximo de 1 (Tabela 4.58), sendo outro indício da qualidade dos resultados obtidos.

Tabela 4.59 - Velocidades teóricas de interesse para concreto C40 15\%, seção superior.

\begin{tabular}{cccc}
\hline \multicolumn{3}{c}{ Velocidade (m/s) } \\
\hline Máxima & Mínima & Média & CV (\%) \\
\hline 7000 & 1160,24 & 4034,21 & 33,94 \\
\hline \multicolumn{3}{c}{ Fonte: Elaborada pelo autor. }
\end{tabular}


Em termos de velocidades, os valores máximos e mínimos respeitam o intervalo pretendido, resultando em velocidade média de 4034,21 m/s (Tabela 4.59). Esse valor permite classificar o concreto como sendo de boa qualidade (Tabela 3.11). Quando a comparação é feita com a velocidade obtida para os prismas aos 7 dias, o valor se encontra mais próximo da direção longitudinal $(4015,3 \mathrm{~m} / \mathrm{s})$ do que da direção transversal $(4272,1 \mathrm{~m} / \mathrm{s})$, estando compreendido entre as duas velocidades.

Observa-se também, uma queda de 9,5\% na velocidade em comparação com a obtida na seção superior da parede C40 de referência $(4458,85 \mathrm{~m} / \mathrm{s})$, fato justificado pela maior porosidade derivada da incorporação de ar (SAINT-PIERRE et al., 2016).

- Parede com concreto C40 15\%, seção inferior:

Figura 4.65 - Imagem tomográfica com distribuição de velocidades de pulso ultrassônico para concreto C40 15\%, seção inferior.
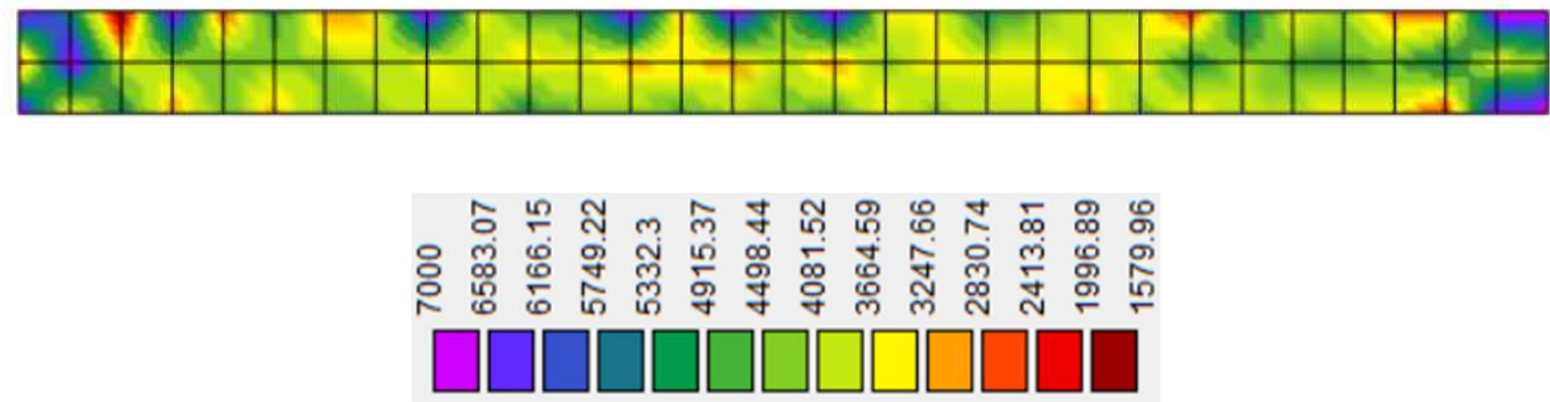

Fonte: Software TUSom.

Figura 4.66 - Comparação de velocidade teórica com experimental em função do comprimento de medição para concreto C40 15\%, seção inferior.

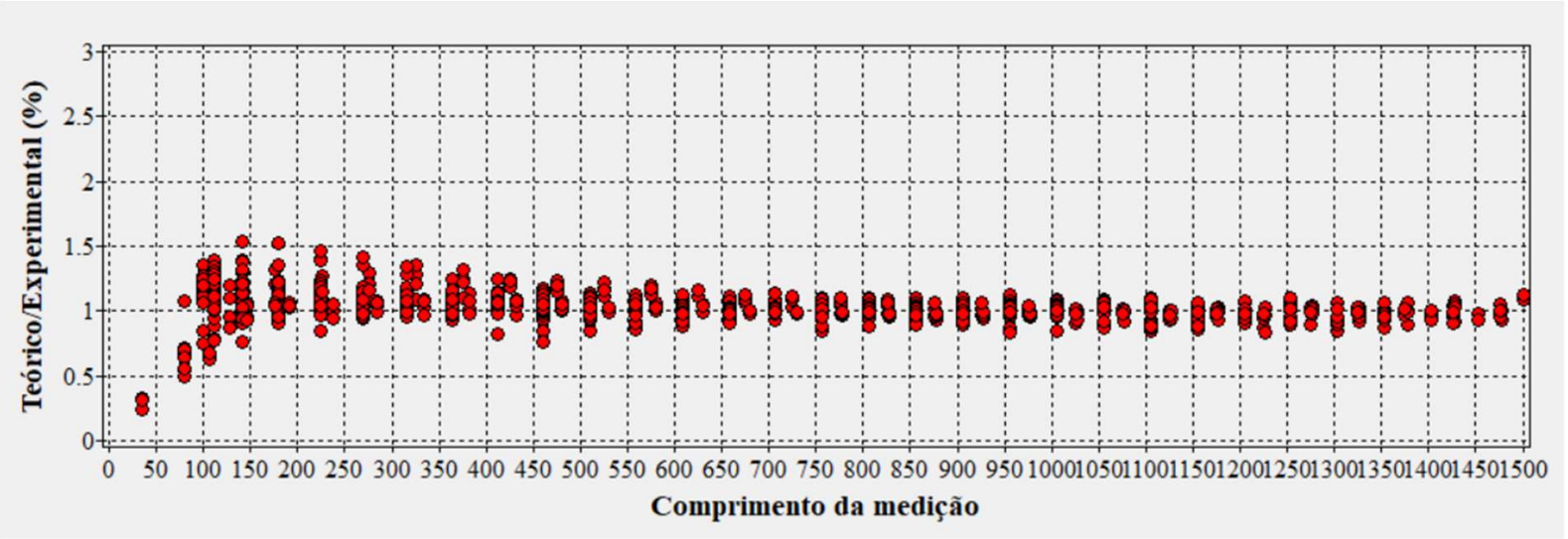

Fonte: Software TUSom. Comprimento em milímetros. 
Assim como na seção superior, a seção inferior em questão apresentou boa distribuição da relação velocidade teórica/experimental ao longo dos diferentes comprimentos de medição (Figura 4.66). Novamente se observa que os resultados para medições mais curtas apresentam maior variação.

Tabela 4.60 - Correlações entre velocidades teóricas e velocidades experimentais para concreto C40 $15 \%$, seção inferior.

\begin{tabular}{ccc}
\hline \multicolumn{3}{c}{ Medições } \\
\hline Média Teó./Exp. & CV (\%) [Teó./Exp.] & Coeficiente $\mathrm{R}^{2}$ \\
\hline 1,04 & 10,52 & 0,9872 \\
\hline \multicolumn{3}{c}{ Fonte: Elaborada pelo autor. }
\end{tabular}

O coeficiente $\mathrm{R}^{2}$ obtido reforça os bons resultados apresentados (Tabela 4.60), sendo ligeiramente menor do que o identificado na seção superior $(0,9894)$.

Tabela 4.61 - Velocidades teóricas de interesse para concreto C40 15\%, seção inferior.

\begin{tabular}{cccc}
\hline \multicolumn{4}{c}{ Velocidade (m/s) } \\
\hline Máxima & Mínima & Média & CV (\%) \\
\hline 7000 & 1579,96 & 4222,05 & 37,31 \\
\hline \multicolumn{3}{c}{ Fonte: Elaborada pelo autor. }
\end{tabular}

Assim como nas outras duas paredes, a velocidade média do pulso ultrassônico ao longo do concreto na seção inferior é maior que na seção superior (4034,21 m/s), um aumento de $4,7 \%$, indicando que o obstáculo imposto para a concretagem da parede não foi mais significativo que a pressão exercida pela maior quantidade de concreto acima da seção analisada. Em outras palavras, a janela não prejudicou a concretagem.

A maior velocidade na seção inferior (Tabela 4.61), da mesma maneira que observado na segunda parede, contradiz o acabamento superficial analisado. Isso porque a nota média de acabamento para os quadrantes superiores nas duas faces da parede C40 15\% foi de 1,04 , enquanto que para os quadrantes de baixo foi de 1,72. Ou seja, pode-se novamente observar que a qualidade do acabamento externo não necessariamente reflete a qualidade da estrutura interna do elemento.

Pode-se observar também que a velocidade média para a seção em análise está dentro do intervalo determinado pelos valores de velocidades médias transversal $(4272,1 \mathrm{~m} / \mathrm{s})$ e longitudinal $(4015,3 \mathrm{~m} / \mathrm{s})$ obtidos para os prismas de mesmo traço aos 7 dias. Conforme 
Tabela 3.11, o concreto da seção inferior dessa parede pode ser caracterizado como de boa qualidade. 


\section{CONCLUSÕES}

A partir dos resultados apresentados, percebe-se a grande influência exercida pela incorporação de ar nos concretos de referência, principalmente em se tratando das resistências à compressão. Para os concretos de classe C25, a queda de resistência média à compressão aos 28 dias foi de $41 \%$ para o C25 9\% e de 59\% para o C25 15\% em relação ao concreto de referência. Já para a classe C40, a resistência à compressão aos 28 dias foi reduzida em 30\% para o C40 9\% e em 46\% para o C40 15\% quando comparado ao traço de referência.

Ainda assim, considerando os objetivos iniciais propostos, os traços C25 e C40 de referência e os C40 9\% e C40 15\% apresentam características e propriedades adequadas, tanto em estado fresco quanto em estado endurecido, para utilização em paredes de concreto moldadas no local.

Os traços C40 9\% e C40 15\% se destacaram devido à redução no consumo de cimento, decorrente da incorporação de ar, associada à manutenção de resistências à compressão características (36,9 MPa e 27,3 MPa, respectivamente) muito próximas dos limites máximo (40 MPa) e mínimo (25 MPa) estabelecidos pela NBR 16055:2012 (ABNT, 2012b).

Em termos de acabamento superficial, as paredes produzidas com os concretos de classe C40 apresentaram bons resultados, sendo que, quanto maior o espalhamento obtido após mistura dos traços, melhor o aspecto visual da parede. Dessa forma, o ajuste do teor de superplastificante, a fim de atender às especificações de autoadensabilidade previstas em norma para um concreto autoadensável aplicado na execução de paredes de concreto moldadas no local, é um fator de extrema importância na obtenção de um bom acabamento superficial.

Observou-se perda de espalhamento nos concretos em estado fresco quando se fez uso de aditivo incorporador de ar, o que contradiz o encontrado na literatura. Porém, entendese que essa perda foi resultado do maior tempo de mistura necessário para incorporar os teores de ar desejados quando em comparação com os traços de referência.

Quando a análise é referente à qualidade da estrutura interna dos concretos, todos os traços produzidos neste trabalho, tanto em prismas quanto em paredes, foram classificados no mínimo como de boa qualidade, visto que a velocidade do pulso ultrassônico obtida sempre foi superior a $3658 \mathrm{~m} / \mathrm{s}$ (Tabela 3.11).

Percebe-se ainda que, conforme comparações feitas com a análise dos painéis de parede com uso do software ImageJ, o acabamento superficial não necessariamente reflete a qualidade da estrutura interna do concreto. Afirma-se isso pelo fato de as maiores notas dadas 
ao acabamento das paredes não estarem sempre associadas às maiores velocidades do pulso ultrassônico.

De maneira geral, o presente trabalho apresentou resultados muito satisfatórios, sendo possível a determinação de traços de concreto com altos teores de ar incorporado que mantiveram propriedades mecânicas suficientes para suas classificações como concreto estrutural (ABNT, 2014a).

- Sugestões para pesquisas futuras:

Propõe-se, como sugestão para trabalhos futuros, que sejam feitos ensaios de massa específica, índice de vazios e absorção de água, além de ensaios de carbonatação, nos concretos C25 e C40 de referência e ainda nos de classe C40 com ar incorporado. Caso esses ensaios apresentem valores adequados, considera-se que os concretos aqui produzidos estarão aptos para utilização em paredes de concreto moldadas no local.

Pode-se ainda realizar ensaios de determinação do teor de ar em concreto fresco por meio método pressométrico, pois entende-se que essa é uma maneira mais precisa para medir o teor de ar do que o método gravimétrico utilizado no presente trabalho.

No caso dos painéis de parede, sugere-se que seja feito procedimento adequado de cura, de maneira que os resultados obtidos nos ensaios se adequem melhor aos resultados obtidos para os corpos de prova.

Além disso, é interessante verificar a possibilidade de controle da incorporação de ar em escala de construção real. Ou seja, definir um procedimento de produção dos traços com uso de caminhões betoneira, de maneira que o teor de ar se mantenha com os valores previstos em projeto. 


\section{REFERÊNCIAS BIBLIOGRÁFICAS}

ACI Committee 318 (ACI 318). Building Code Requirements for Structural Concrete (ACI 318-08) and Commentary. American Concrete Institute. 2008. 471p.

ALENCAR, R. S. A. Dosagem do concreto auto-adensável: produção de pré-fabricados. 2008. Dissertação (Mestrado em Engenharia de Construção Civil e Urbana) - Escola Politécnica, Universidade de São Paulo. São Paulo. 2008. 176p.

ALMEIDA, E.; CARRETERO, N. Revisão dos sistemas de classificação da qualidade superficial do betão à vista. Encontro Nacional BETÃO ESTRUTURAL. 2016. 11p.

ASSOCIAÇÃO BRASILEIRA DE CIMENTO PORTLAND (ABCP). Manual Técnico para Implementação: Habitação 1.0: Bairro saudável. População saudável. 1 Ed. São Paulo: ABCP. 2002. 88p.

ASSOCIAÇÃO BRASILEIRA DE NORMAS TÉCNICAS (ABNT). NBR 5738 - Concreto Procedimento para moldagem e cura de corpos de prova. Rio de Janeiro. 2015a. 9p.

. NBR 5739 - Concreto - Ensaio de compressão de corpos-de-prova cilíndricos. Rio de Janeiro. 2007. 9p.

. NBR 6118 - Projeto de estruturas de concreto - Procedimento. Rio de Janeiro. 2014a. $238 \mathrm{p}$.

. NBR 7222 - Concreto e argamassa - Determinação da resistência à tração por compressão diametral de corpos de prova cilíndricos. Rio de Janeiro. 2011. 5p.

. NBR 7681-2 - Calda de cimento para injeção - Parte 2: Determinação do índice de fluidez e da vida útil - Método de ensaio. Rio de Janeiro. 2013. 4p.

. NBR 8522 - Concreto - Determinação do módulo estático de elasticidade à compressão. Rio de Janeiro. 2008a. 16p.

. NBR 8802 - Concreto endurecido - Determinação da velocidade de propagação de onda. Rio de Janeiro. 2019. 11p.

. NBR 9833 - Concreto fresco - Determinação da massa específica, do rendimento e do teor de ar pelo método gravimétrico. Rio de Janeiro. 2008b. $7 \mathrm{p}$.

. NBR 12142 - Concreto - Determinação da resistência à tração na flexão de corpos de prova prismáticos. Rio de Janeiro. 2010a. 5p.

. NBR 12653 - Materiais pozolânicos — Requisitos. Rio de Janeiro. 2014b. 6p.

. NBR 12655 - Concreto de cimento Portland - Preparo, controle, recebimento e aceitação - Procedimento. Rio de Janeiro. 2015b. 23p.

. NBR 13956 - Sílica ativa para uso com cimento Portland em concreto, argamassa e pasta - Parte 1: Requisitos. Rio de Janeiro. 2012a. 6p. 
. NBR 15823-1 - Concreto autoadensável - Parte 1: Classificação, controle e recebimento no estado fresco. Rio de Janeiro. 2017a. 14p.

. NBR 15823-2 - Concreto autoadensável - Parte 2: Determinação do espalhamento, do tempo de escoamento e do índice de estabilidade visual - Método do cone de Abrams. Rio de Janeiro. 2017b. 5p.

. NBR 15823-3 - Concreto autoadensável - Parte 3: Determinação da habilidade passante - Método do anel J. Rio de Janeiro. 2017c. 4p.

. NBR 15823-4 - Concreto autoadensável - Parte 4: Determinação da habilidade passante - Métodos da caixa L e da caixa U. Rio de Janeiro. 2017d. 7p.

NBR 15823-5 - Concreto autoadensável - Parte 5: Determinação da viscosidade Método do funil V. Rio de Janeiro. 2017e. 4p.

. NBR 15823-6 - Concreto autoadensável - Parte 6: Determinação da resistência à segregação - Métodos da coluna de segregação e da peneira. Rio de Janeiro. 2017f. 6p.

NBR 15894-1 - Metacaulim para uso com cimento Portland em concreto, argamassa e pasta - Parte 1: Requisitos. Rio de Janeiro. 2010b. 8p.

NBR 16055 - Parede de concreto moldada no local para a construção de edificações Requisitos e procedimentos. Rio de Janeiro. 2012b. 35p.

. NBR 16605 - Cimento Portland e outros materiais em pó — Determinação da massa específica. Rio de Janeiro. 2017g. 4p.

. NBR NM 248 - Agregados - Determinação da composição granulométrica. Rio de Janeiro. 2003. 6p. 2000.3p.

NBR NM 30 - Agregado miúdo - Determinação da absorção de água. Rio de Janeiro.

. NBR NM 52 - Agregado miúdo - Determinação de massa específica e massa específica aparente. Rio de Janeiro. 2009a. 6p.

. NBR NM 53 - Agregado graúdo - determinação de massa específica, massa específica aparente e absorção de água. Rio de Janeiro. 2009b. 8p.

ACI Committee 318 (ACI 318). Building Code Requirements for Structural Concrete (ACI 318-08) and Commentary. American Concrete Institute. 2008. 471p.

ALENCAR, R. S. A. Dosagem do concreto auto-adensável: produção de pré-fabricados. 2008. Dissertação (Mestrado em Engenharia de Construção Civil e Urbana) - Escola Politécnica, Universidade de São Paulo. São Paulo. 2008. 176p.

ALMEIDA, E.; CARRETERO, N. Revisão dos sistemas de classificação da qualidade superficial do betão à vista. Encontro Nacional BETÃO ESTRUTURAL. 2016. 11p. 
ASSOCIAÇÃO BRASILEIRA DE CIMENTO PORTLAND (ABCP). Manual Técnico para Implementação: Habitação 1.0: Bairro saudável. População saudável. 1 Ed. São Paulo: ABCP. 2002. 88p.

ASSOCIAÇÃO BRASILEIRA DE NORMAS TÉCNICAS (ABNT). NBR 5738 - Concreto Procedimento para moldagem e cura de corpos de prova. Rio de Janeiro. 2015a. 9p.

ASTM C597. Standard Test Method for Pulse Velocity Through Concrete. ASTM InternationaL. 2016. 4p.

ASTM E1876. Standard Test Method for Dynamic Young's Modulus, Shear Modulus, and Poisson's Ratio by Impulse Excitation of Vibration. ASTM International. 2015. 17 p.

ATTACHAIYAWUTH, A.; SOVANNSATHYA, R.; TANAKA, K.; OUCHI, M. Improvement of Self-Compactibility of Air-Entrained Self-Compacting Concrete with Finer Entrained Air. Journal of Advanced Concrete Technology 14. 2016. p. 55-69.

BARFIELD, M.; GHAFOORI, N. Air-entrained self-consolidating concrete: A study of admixture sources. Construction and Building Materials 26. 2012. p. 490-496.

BATTAGIN, A. F. Cimento Portland. In: ISAIA, G. C. CONCRETO: Ciência e tecnologia. São Paulo: Ipsis. v. 1. 2011. p. 185-232.

BENITO, F. J.; VALCUENDE, M.; PARRA, C.; RODRÍGUEZ, C.; MIÑANO, I. Acabado superficial de hormigones autocompactantes. - Método ICS. IV Congresso Ibero-americano sobre Betão Auto-compactável - BAC2015. 2015. p. 601-610.

BEZERRA, L. M. C. M. Planejamento e controle da produção com a utilização de células de trabalho: estudo de caso em construções com vedações verticais em concreto armado moldadas in loco. Dissertação (Mestrado) - Escola de Engenharia de São Carlos, Universidade de São Paulo. São Carlos. 2010. 157p.

CASTRO, A. L. Aplicação de conceitos reológicos na tecnologia dos concretos de alto desempenho. Tese (Doutorado) - Escola de Engenharia de São Carlos/ Instituto de Física de São Carlos/ Instituto de Química de São Carlos, Universidade de São Paulo. São Carlos. 2007. $302 p$.

CASTRO, A. L.; LIBORIO, J. B. L. Considerações sobre o processo de produção de concreto de alto desempenho para estruturas pré-moldadas. $1^{\circ}$ Encontro Nacional de Pesquisa-ProjetoProdução em Concreto pré-moldado. 2005. 10p.

CIB WORKING COMMISSION W29. Tolerances on blemishes of concrete. CIB report $\mathrm{n}^{\mathrm{o}} 24$. 1973. 8p.

COMUNIDADE DA CONSTRUÇÃO, Paredes de concreto: coletânea de ativos 2007/2008. 216p.

COMUNIDADE DA CONSTRUÇÃO, Paredes de concreto: coletânea de ativos 2009/2010. 78 p. 
COSTA, C. P.; LIMA, J. R. P. Três sistemas construtivos em empreendimento residencial econômico. Concreto \& Construções, e. 90. 2018. p. 21-25.

DE LARRARD, F.; BOSC, F.; CATHERINE, C.; DEFLORENNE, F. The AFREM method for the mix-design of high performance concrete. Materials and Structures, v. 30. 1997. p. 439-446. Diretriz SINAT $\mathrm{n}^{\circ} 004$ - Sistema construtivo TENDA em paredes de concreto armado moldadas no local. Brasília. 2011. 13p.

DU, L.; FOLLIARD, K. J. Mechanisms of air entrainment in concrete. Cement and Concrete Research 35. 2005. p. 1463-1471.

EL DEBS, M. K. Concreto pré-moldado: fundamentos e aplicações. 2 ed. São Paulo: Oficina de Textos. 2017. 456p.

EN 445. Lechadas para Tendones de Pretensado. Métodos de Ensayo, CEN. 1996. 12p.

EUROPEAN FEDERATION FOR SPECIALIST CONSTRUCTION CHEMICALS AND CONCRETE SYSTEMS (EFNARC), Specification and Guidelines for self-compacting concrete. In EFNAC, ISBN: 0-9539733-4-4. 2002. 32p.

EUROPEAN FEDERATION FOR SPECIALIST CONSTRUCTION CHEMICALS AND CONCRETE SYSTEMS (EFNARC). Specification and guidelines for self-compacting concrete. In: EFNARC. 2005. 68p.

FARIA, R. Paredes maciças. Revista Téchne, e. 143. 2009. Disponível em $<$ http://techne17.pini.com.br/engenharia-civil/143/paredes-macicas-286570-1.aspx $>$ acesso em: 15 fev. 2018.

FELDMAN, R. F. Non-Destructive Testing of Concrete. CBD-187. National Research Council of Canada. 1977. 6p.

GARNIER, V.; CHAIX, J. F.; CORNELOUP, G. Caractérisation non destructive du béton par l'analyse d'ondes ultrasonores. Bulletin du LCPC 239. 2002. p. 105-118.

GHAZI, F. K., AL JADIRI, R. S. New Method for Proportioning Self-Consolidating Concrete Based on Compressive Strength Requirements. ACI Materials Journal. n. 107. 2010. p. 490497.

GOMES, P. C. C. Optimization and characterization of high-strength selfcompacting concrete. Tese (Doutorado) - Escola Tècnica Superior D'Enginyers de Camins, Universitat Politècnica de Catalunya. Barcelona. 2002. 139p.

GOMES, P. C. C.; GETTU, R.; AGULlÓ, L. Uma nova metodologia para obtenção de concreto autoadensável de alta resistência com aditivos minerais. In: V Simpósio EPUSP sobre Estruturas de Concreto. São Paulo. 2003. 14p.

GOMES, P.C.C.; BARROS, A.R. Métodos de dosagem de concreto autoadensável. 1 ed. São Paulo: PINI. 2009. 165p. 
KANTRO, D. L. Influence of Water-Reducing Admixtures on Properties of Cement Paste - A Miniature Slump Test. Cement, Concrete and Aggregates. v. 2. n. 2. 1980. p. 95-108.

KOSMATKA, S. H.; KERKHOFF, B.; PANARESE, W. C. Design and Control of Concrete Mixtures, EB001, 14th edition, Portland Cement Association, Skokie, Illinois, USA. 2002 $358 \mathrm{p}$.

LEITE, A. M. Avaliação do uso da macrofibra polimérica na composição de concreto para fins estruturais. Dissertação (Mestrado em Estruturas) - Escola de Engenharia de São Carlos, Universidade de São Paulo. São Carlos. 2018. 259p.

LORDSLEEM JUNIOR, A. C.; FONTENELLE, E. C.; BARROS, M. M. S. B. de; SABBATINI, F. H. Estágio atual do uso de paredes maciças moldadas no local em São Paulo. In Anais. São Paulo: Epusp/PCC. 1998. p. 151-158.

MEHTA, P. K.; MONTEIRO, P. J. M. Concrete - Microstructure, Properties and Materials. 13th ed. United States: McGraw-Hill. 2014. 659p.

MISURELLI, H.; MASSUDA, C. Paredes de concreto. Revista Téchne, e. 147. 2009. Disponível em $<$ http://techne17.pini.com.br/engenharia-civil/147/paredes-de-concreto285766-1.aspx> acesso em: 16 fev. 2018.

MONGE, R.; SILVA, J. B. R.; VAQUERO Y MAYOR, A. A construção de um sistema de sucesso. Concreto \& Construções, e. 90. 2018. p. 42-46.

MONGE, R.; WENDLER, A. Paredes de concreto - como ter uma obra sem manifestações patológicas. Concreto \& Construções, e. 90. 2018. p. 38-41.

NAIK, T. R.; MALHOTRA, V. M.; POPOVICS, J. S. The Ultrasonic Pulse Velocity Method. In: CARINA, N. J.; MALHOTRA, T. R. Nondestructive testing of concrete. e. 2. 2003. p. 8.1-8.19

NUNES, V. Q. G. Análise estrutural de edifícios de paredes de concreto armado. Dissertação (Mestrado em Engenharia de Estruturas) - Escola de Engenharia de São Carlos, Universidade de São Paulo. São Carlos. 2011. 152p.

OKAMURA, H. OZAWA, K. OUCHI, M. Self-compacting concrete. Structural Concrete. n. 1. 2000. p. 3-17.

OKAMURA, H.; OUCHI, M. Self-Compacting Concrete. Journal of Advanced Concrete Technology. v 1. n. 1. 2003. p. 5-15.

OKAMURA, H.; OZAWA, K. Mix design for self-compacting concrete. Concrete Library of JSCE. n. 25. 1995. p. 107-120.

OTANI, L. B.; PEREIRA, A. H. A. Estimativa do módulo de elasticidade estático de concretos utilizando a Técnica de Excitação por Impulso. Informativo técnico-científico ITC-07/ATCP. 2017. 36p. 
POPOVICS, S. Verification of relationships between mechanical properties of concrete like materials. Matériaux et Constructions. v. 8. 1975. p. 183-191.

SAAK, A. W.; JENNINGS, H. M.; SHAH, S. P. New methodology for designing selfcompacting concrete. ACI Materials Journal 98. 2001. p. 429-439.

SACHT, H. M. Painéis de vedação de concreto moldados in loco: avaliação de desempenho térmico e desenvolvimento de concretos. Dissertação (Mestrado) - Escola de Engenharia de São Carlos, Universidade de São Paulo. São Carlos. 2008. 286p.

SACHT, H. M.; ROSSIGNOLO, J. H. Desenvolvimento de concretos para vedações verticais moldadas in loco. Revista Tecnológica. v. 17. 2008. p. 13-18.

SAINT-PIERRE, F.; PHILIBERT, A.; GIROUX, B.; RIVARD, P. Concrete Quality Designation based on Ultrasonic Pulse Velocity. Construction and Building Materials 125. 2016. p. 1022-1027.

SANTOS, R. F. C. Estudo de concretos auto-adensáveis, com aditivo incorporador de ar, utilizados na produção de paredes de concreto armado moldadas no local. Dissertação (Mestrado em Habitação: Planejamento e Tecnologia) - Instituto de Pesquisas Tecnológicas do Estado de São Paulo. São Paulo. 2012. 181p.

Shi, C.; Wu, Z.; Lv, K.; Wu, L. A review on mixture design methods for self-compacting concrete. Construction and Building Materials 84. 2015. p. 387-398.

SILVA, F. B. Paredes de concreto armado moldadas in loco. Revista Téchne, e. 167. 2011. Disponível em $<$ http://techne17.pini.com.br/engenharia-civil/167/paredes-de-concretoarmado-moldadas-in-loco-286799-1.aspx> acesso em: 15 fev. 2018.

SOVANNSATHYA, R.; OUCHI, M.; PUTHIPAD, N.; ATTACHAIYAWUTH, A. Improving the stability of entrained air in self-compacting concrete by optimizing the mix viscosity and air entraining agent dosage. Construction and Building Materials 148. 2017. p. 531-537.

SU, N.; HSU, K.; CHAI, H. A simple mix design method for self-compacting concrete. Cement and Concrete Research 31. 2001. p. 1799-1807.

ZERBINO, R.; BARRAGÁN, B.; AGULlÓ, L.; GARCÍA, T.; GETTU, R. Reologia de hormigones autocompactables. Ciencia y Tecnologia del Hormigón. Laboratorio de Entrenamiento Multidisciplinario para la Investigación Tecnológica - LEMIT. Comision de Investigaciones Cientificas de la Provincia de Buenos Aires. n. 13. 2006. p. 51-64. 


\section{APENDICE A - CARACTERIZAÇÃO DOS MATERIAIS CONSTITUINTES}

$\mathrm{Na}$ sequência estão apresentadas tabelas para caracterização dos materiais utilizados neste trabalho.

Tabela A.1 - Massa específica dos materiais em pó.

\begin{tabular}{cc}
\hline Material & Massa específica $\left(\mathbf{g} / \mathbf{c m}^{\mathbf{3}}\right)$ \\
\hline Cimento & 2,89 \\
Sílica & 2,18 \\
Fíler & 2,63 \\
\hline \multicolumn{2}{c}{ Fonte: Elaborada pelo autor. }
\end{tabular}

Fonte: Elaborada pelo autor.

Tabela A.2 - Parâmetros físicos para agregados miúdos.

\begin{tabular}{ccccc}
\hline Agregado & $\begin{array}{c}\text { Massa específica } \\
\text { aparente do agregado } \\
\text { seco }\left(\mathbf{g} / \mathbf{c m}^{\mathbf{3}}\right)\end{array}$ & $\begin{array}{c}\text { Massa específica do } \\
\text { agregado saturado } \\
\text { superfície seca } \mathbf{( g / \mathbf { c m } ^ { 3 } )}\end{array}$ & $\begin{array}{c}\text { Massa } \\
\text { específica } \\
\mathbf{( g / \mathbf { c m } ^ { 3 } )}\end{array}$ & $\begin{array}{c}\text { Absorção } \\
\text { de água } \\
\mathbf{( \% )}\end{array}$ \\
\hline Areia fina & 2,56 & 2,56 & 2,57 & 0,18 \\
Areia média & 2,56 & 2,57 & 2,58 & 0,24 \\
\hline \multicolumn{7}{c}{ Fonte: Elaborada pelo autor. } \\
\end{tabular}

Tabela A.3 - Parâmetros físicos para agregados graúdos.

\begin{tabular}{ccccc}
\hline Agregado & $\begin{array}{c}\text { Massa específica } \\
\text { do agregado seco } \\
\left(\mathbf{g} / \mathbf{c m}^{\mathbf{3}}\right)\end{array}$ & $\begin{array}{c}\text { Massa específica do } \\
\text { agregado saturado } \\
\text { superfície seca }\left(\mathbf{g} / \mathbf{c m}^{\mathbf{3}}\right)\end{array}$ & $\begin{array}{c}\text { Massa específica } \\
\text { aparente }\left(\mathbf{g} / \mathbf{c m}^{\mathbf{3}}\right)\end{array}$ & $\begin{array}{c}\text { Absorção } \\
\text { de água } \\
(\%)\end{array}$ \\
\hline Brita & 2,99 & 2,88 & 2,83 & 1,87 \\
\hline
\end{tabular}

Fonte: Elaborada pelo autor.

Tabela A.4 - Distribuição granulométrica para areia fina.

\begin{tabular}{cc}
\hline $\begin{array}{c}\text { Abertura da } \\
\text { peneira (mm) }\end{array}$ & \% Passante \\
\hline 1,18 & 100,0 \\
0,6 & 99,7 \\
0,3 & 61,7 \\
0,15 & 7,5 \\
0,001 & 0,0 \\
\hline Fonte: Elaborada pelo autor.
\end{tabular}


Tabela A.5 - Distribuição granulométrica para areia média.

\begin{tabular}{cc}
\hline $\begin{array}{c}\text { Abertura da } \\
\text { peneira (mm) }\end{array}$ & \% Passante \\
\hline 12,5 & 100,0 \\
9,5 & 99,6 \\
6,3 & 98,6 \\
4,75 & 98,2 \\
2,36 & 96,1 \\
1,18 & 84,1 \\
0,6 & 58,9 \\
0,3 & 31,4 \\
0,15 & 4,4 \\
0,001 & 0,0 \\
\hline Fonte: Elaborada pelo autor.
\end{tabular}

Tabela A.6 - Distribuição granulométrica para brita.

\begin{tabular}{cc}
\hline $\begin{array}{c}\text { Abertura da } \\
\text { peneira (mm) }\end{array}$ & \% Passante \\
\hline 12,5 & 100,0 \\
9,5 & 99,8 \\
6,3 & 61,2 \\
4,75 & 11,4 \\
2,36 & 0,9 \\
1,18 & 0,7 \\
0,6 & 0,7 \\
0,3 & 0,7 \\
0,15 & 0,4 \\
0,001 & 0,0 \\
\hline Fonte: Elaborada pelo autor.
\end{tabular}

Tabela A.7 - Dimensão máxima característica e módulo de finura dos agregados.

\begin{tabular}{cccc}
\hline Propriedade & Areia fina & Areia média & Brita \\
\hline $\begin{array}{c}\text { Dimensão máxima } \\
\text { característica (mm) }\end{array}$ & 0,60 & 2,36 & 9,50 \\
Módulo de finura & 1,20 & 2,40 & 5,90 \\
\hline & Fonte: Elaborada pelo autor.
\end{tabular}


Figura A.1 - Curvas de distribuição granulométrica dos agregados.

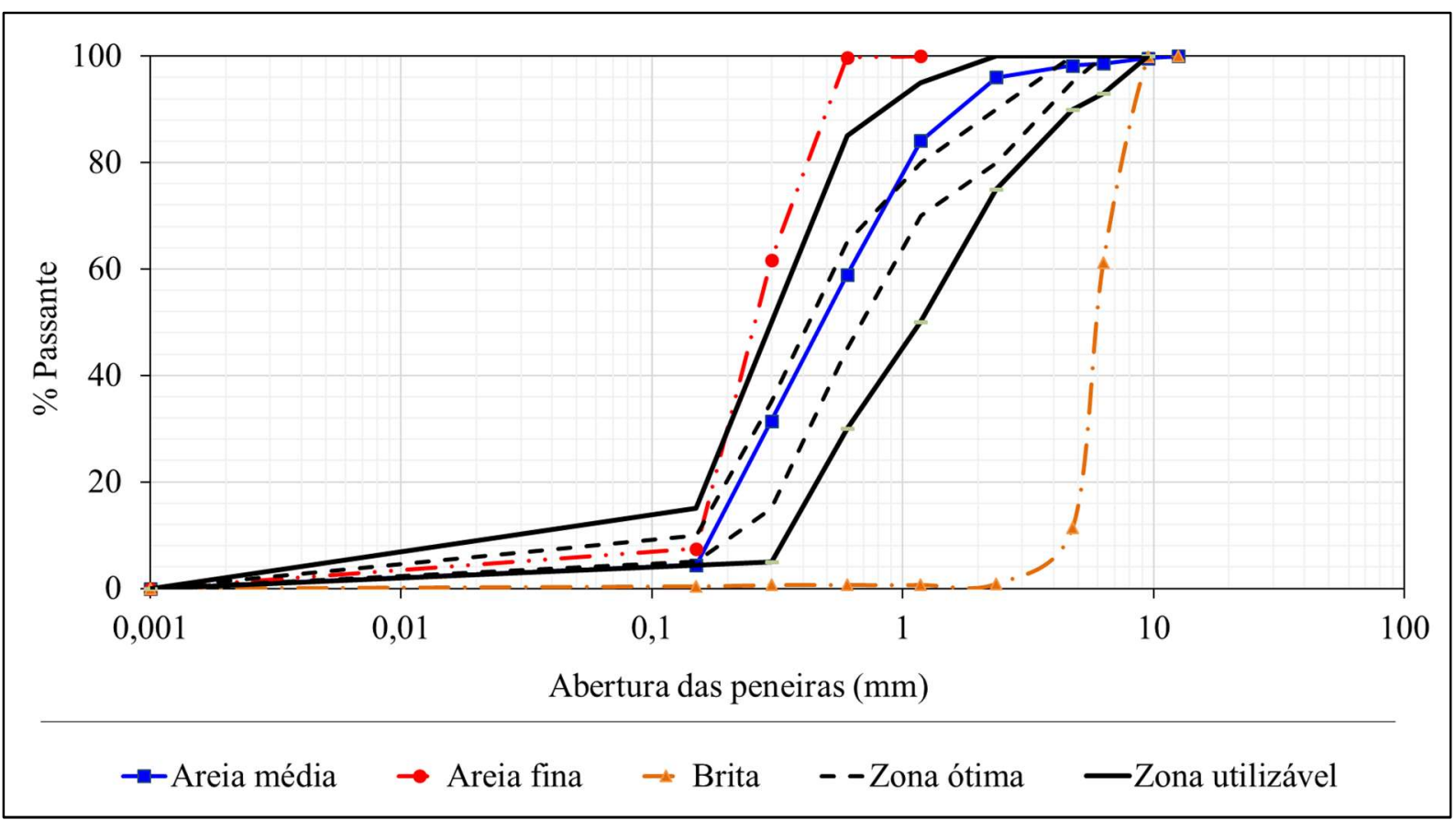

Fonte: Elaborada pelo autor.

Tabela A.8 - Massa específica dos aditivos utilizados.

\begin{tabular}{cc}
\hline Aditivo & $\begin{array}{c}\text { Massa Específica } \\
\left(\mathbf{g} / \mathbf{c m}^{\mathbf{3}}\right)\end{array}$ \\
\hline $\begin{array}{c}\text { ADVA CAST 525 } \\
\text { (superplastificante) }^{14}\end{array}$ & $1,040-1,060$ \\
$\begin{array}{c}\text { DARAFILL EXP 300 } \\
\text { (incorporador de ar) }^{15}\end{array}$ & $0,980-1,020$ \\
\hline
\end{tabular}

Fonte: Elaborada pelo autor.

14 GCPAT. ADVA. Aditivo superplastificante (SP II) para concreto. Disponível em $<$ https://gcpat.com.br/pt-br/solutions/products/adva-high-range-water-reducers/adva> acesso em: 18 de março de 2019.

15 GCPAT. DARAFILL. Aditivo incorporador de ar. Disponível em <https://gcpat.com.br/ptbr/solutions/products/darafill-0> acesso em: 17 de março de 2019. 


\section{APENDICE B - APLICAÇÃO DE CRITÉRIO DE CHAUVENET PARA VALORES DE RESISTÊNCIA À COMPRESSÃO}

Na sequência estão apresentadas tabelas com aplicação do critério de Chauvenet a fim de determinar se algum dos resultados obtidos deve ser descartado das análises. De acordo com o critério, o valor limite da variação dos dados em relação ao desvio padrão deve ser de 1,65 para análises com 5 leituras e 1,54 para 4 leituras para que o resultado não seja considerado duvidoso.

Tabela A.9 - C25 referência - Critério de Chauvenet para resultados de resistência à compressão aos 28 dias.

\begin{tabular}{ccc}
\hline \multicolumn{3}{c}{ C25 Referência - 28 Dias } \\
\hline Resistência (MPa) & Critério de Chauvenet & Resultado \\
\hline 41,340 & 1,42 & Ok \\
43,640 & 0,27 & Ok \\
43,560 & 0,21 & Ok \\
44,560 & 0,94 & Ok \\
\hline Média & 43,28 & \\
Desvio padrão & 1,37 & \\
Coeficiente de variação & 3,16 & \\
\hline \multicolumn{4}{c}{ Fonte: Elaborada pelo autor. } \\
\hline
\end{tabular}

Tabela A.10 - C25 9\% - Critério de Chauvenet para resultados de resistência à compressão aos 28 dias.

\begin{tabular}{ccc}
\hline \multicolumn{4}{c}{ C25 9\% - 28 Dias } \\
\hline Resistência (MPa) & Critério de Chauvenet & Resultado \\
\hline 25,47 & 0,44 & Ok \\
28,15 & 1,74 & Não ok \\
25,46 & 0,44 & Ok \\
25,87 & 0,11 & Ok \\
25,08 & 0,75 & Ok \\
\hline Média & 26,01 & \\
Desvio padrão & 1,23 & \\
Coeficiente de variação & 4,73 & \\
\hline \multicolumn{4}{c}{ Fonte: Elaborada pelo autor. } \\
\hline
\end{tabular}

Segundo o critério de Chauvenet, o valor de 28,15 MPa deve ser descartado. Sendo assim, esse valor não é considerado nos cálculos de média, desvio padrão e coeficiente de variação, conforme apresentado na Tabela A.11. 
Tabela A.11 - C25 9\% - Critério de Chauvenet refeito para resultados de resistência à compressão aos 28 dias.

\begin{tabular}{ccc}
\hline \multicolumn{3}{c}{ C25 9\% - 28 Dias } \\
\hline Resistência (MPa) & Critério de Chauvenet & Resultado \\
\hline 25,47 & 0,00 & Ok \\
25,46 & 0,03 & Ok \\
25,87 & 1,24 & Ok \\
25,08 & 1,21 & Ok \\
\hline Média & 25,47 & \\
Desvio padrão & 0,32 & \\
Coeficiente de variação & 1,27 & \\
\hline \multicolumn{4}{c}{ Fonte: Elaborada pelo autor. } \\
\hline
\end{tabular}

Tabela A. 12 - C25 15\% - Critério de Chauvenet para resultados de resistência à compressão aos 28 dias.

\begin{tabular}{ccc}
\hline \multicolumn{4}{c}{ C25 15\% - 28 Dias } \\
\hline Resistência (MPa) & Critério de Chauvenet & Resultado \\
\hline 17,32 & 0,58 & Ok \\
17,69 & 0,20 & Ok \\
16,66 & 1,25 & Ok \\
18,88 & 1,02 & Ok \\
18,86 & 1,00 & Ok \\
\hline Média & 17,88 & \\
Desvio padrão & 0,97 & \\
Coeficiente de variação & 5,45 & \\
\hline \multicolumn{4}{c}{ Fonte: Elaborada pelo autor. } \\
\hline
\end{tabular}

Tabela A.13 - C40 referência - Critério de Chauvenet para resultados de resistência à compressão aos 28 dias.

\begin{tabular}{ccc}
\hline \multicolumn{3}{c}{ C40 Referência - 28 Dias } \\
\hline Resistência (MPa) & Critério de Chauvenet & Resultado \\
\hline 62,610 & 0,06 & Ok \\
60,750 & 0,77 & Ok \\
66,080 & 1,62 & Ok \\
62,420 & 0,02 & Ok \\
60,490 & 0,89 & Ok \\
\hline Média & 62,47 & \\
Desvio padrão & 2,23 & \\
Coeficiente de variação & 3,57 & \\
\hline \multicolumn{4}{c}{ Fonte: Elaborada pelo autor. } \\
\hline
\end{tabular}


Tabela A.14 - C40 9\% - Critério de Chauvenet para resultados de resistência à compressão aos 28 dias.

\begin{tabular}{ccc}
\hline \multicolumn{4}{c}{ C40 9\% - 28 Dias } \\
\hline Resistência (MPa) & Critério de Chauvenet & Resultado \\
\hline 43,43 & 0,41 & Ok \\
42,49 & 0,04 & Ok \\
39,08 & 1,70 & Não ok \\
43,60 & 0,49 & Ok \\
44,31 & 0,84 & Ok \\
\hline Média & 42,58 & \\
Desvio padrão & 2,06 & \\
Coeficiente de variação & 4,84 \\
\hline \multicolumn{4}{c}{} \\
\hline
\end{tabular}

Novamente se observa um valor a ser descartado conforme critério de Chauvenet. Dessa forma, o valor de 39,08 MPa será desconsiderado.

Tabela A.15 - C40 9\% - Critério de Chauvenet refeito para resultados de resistência à compressão aos 28 dias.

\begin{tabular}{ccc}
\hline \multicolumn{3}{c}{ C40 9\% - 28 Dias } \\
\hline Resistência (MPa) & Critério de Chauvenet & Resultado \\
\hline 43,43 & 0,04 & Ok \\
42,49 & 1,29 & Ok \\
43,60 & 0,19 & Ok \\
44,31 & 1,14 & Ok \\
\hline Média & 43,46 & \\
Desvio padrão & 0,75 & \\
Coeficiente de variação & 1,72 & \\
\multicolumn{4}{c}{ Fonte: Elaborada pelo autor. } \\
\hline
\end{tabular}


186

Tabela A.16 - C40 15\% - Critério de Chauvenet para resultados de resistência à compressão aos 28 dias.

\begin{tabular}{ccc}
\hline & C40 - 15\% - 28 Dias & \\
\hline Resistência (MPa) & Critério de Chauvenet & Resultado \\
\hline 34,19 & 0,16 & Ok \\
36,34 & 1,39 & Ok \\
31,64 & 1,28 & Ok \\
34,42 & 0,30 & Ok \\
32,91 & 0,56 & Ok \\
\hline Média & 33,90 & \\
Desvio padrão & 1,76 & \\
Coeficiente de variação & 5,19 & \\
\hline \multicolumn{4}{c}{} \\
\hline
\end{tabular}




\section{APENDICE C - APLICAÇÃO DE CRITÉRIO DE CHAUVENET PARA VALORES DE RESISTÊNCIA À TRAÇÃO}

Nessa seção são apresentadas análises com o critério de Chauvenet para os valores de resistência à tração aos 28 dias. Considerando 3 leituras, o valor limite da variação dos dados em relação ao desvio padrão deve ser de 1,38 para que o resultado não seja considerado duvidoso.

Tabela A.17 - C25 referência - Critério de Chauvenet para resultados de resistência à tração por compressão diametral aos 28 dias.

\begin{tabular}{ccc}
\hline \multicolumn{4}{c}{ C25 Referência - 28 Dias } \\
\hline Resistência (MPa) & Critério de Chauvenet & Resultado \\
\hline 3,991 & 1,15 & Ok \\
3,733 & 0,58 & Ok \\
3,735 & 0,57 & Ok \\
\hline Média & 3,82 & \\
Desvio padrão & 0,15 & \\
Coeficiente de variação & 3,88 & \\
\multicolumn{4}{c}{ Fonte: Elaborada pelo autor. } \\
\end{tabular}

Tabela A.18 - C25 9\% - Critério de Chauvenet para resultados de resistência à tração por compressão diametral aos 28 dias.

\begin{tabular}{ccc}
\hline \multicolumn{4}{c}{ C25 9\% - 28 Dias } \\
\hline Resistência (MPa) & Critério de Chauvenet & Resultado \\
\hline 2,758 & 0,11 & Ok \\
2,414 & 1,05 & Ok \\
3,002 & 0,94 & Ok \\
\hline Média & 2,72 \\
Desvio padrão & 0,30 \\
Coeficiente de variação & 10,84 \\
\hline \multicolumn{4}{c}{ Fonte: Elaborada pelo autor. } \\
\hline \multicolumn{4}{c}{} \\
\hline
\end{tabular}


Tabela A.19 - C25 15\% - Critério de Chauvenet para resultados de resistência à tração por compressão diametral aos 28 dias.

\begin{tabular}{ccc}
\hline \multicolumn{4}{c}{ C25 15\% - 28 Dias } \\
\hline Resistência (MPa) & Critério de Chauvenet & Resultado \\
\hline 1,484 & 1,14 & Ok \\
1,687 & 0,43 & Ok \\
1,724 & 0,71 & Ok \\
\hline Média & 1,63 \\
Desvio padrão & 0,13 \\
Coeficiente de variação & 7,92 \\
\hline \multicolumn{4}{c}{ Fonte: Elaborada pelo autor. } \\
\hline
\end{tabular}

Tabela A.20 - C40 referência\% - Critério de Chauvenet para resultados de resistência à tração por compressão diametral aos 28 dias.

\begin{tabular}{ccc}
\hline \multicolumn{3}{c}{ C40 Referência - 28 Dias } \\
\hline Resistência (MPa) & Critério de Chauvenet & Resultado \\
\hline 4,704 & 0,07 & Ok \\
4,759 & 0,97 & $\mathrm{Ok}$ \\
4,637 & 1,03 & $\mathrm{Ok}$ \\
\hline Média & 4,70 \\
Desvio padrão & 0,06 \\
Coeficiente de variação & 1,30 \\
\hline \multicolumn{4}{c}{ Fonte: Elaborada pelo autor. } \\
\hline
\end{tabular}

Tabela A.21 - C40 9\% - Critério de Chauvenet para resultados de resistência à tração por compressão diametral aos 28 dias.

\begin{tabular}{ccc}
\hline \multicolumn{3}{c}{ C40 9\% - 28 Dias } \\
\hline Resistência (MPa) & Critério de Chauvenet & Resultado \\
\hline 1,484 & 1,14 & Ok \\
1,687 & 0,43 & Ok \\
1,724 & 0,71 & Ok \\
\hline Média & 1,63 \\
Desvio padrão & 0,13 & \\
Coeficiente de variação & 7,92 & \\
\hline \multicolumn{4}{c}{ Fonte: Elaborada pelo autor. } \\
\hline
\end{tabular}


Tabela A.22 - C40 15\% - Critério de Chauvenet para resultados de resistência à tração por compressão diametral aos 28 dias.

\begin{tabular}{ccc}
\hline \multicolumn{4}{c}{ C40 - 15\% - 28 Dias } \\
\hline Resistência (MPa) & Critério de Chauvenet & Resultado \\
\hline 2,385 & 1,14 & Ok \\
2,269 & 0,42 & Ok \\
2,247 & 0,72 & Ok \\
\hline Média & 2,30 \\
Desvio padrão & 0,07 & \\
Coeficiente de variação & 3,22 & \\
\multicolumn{4}{c}{ Fonte: Elaborada pelo autor. } \\
& & \\
\end{tabular}

Tabela A.23 - C25 referência - Critério de Chauvenet para resultados de resistência à tração por flexão aos 28 dias.

\begin{tabular}{ccc}
\hline \multicolumn{4}{c}{ C25 Referência - 28 Dias } \\
\hline Resistência (MPa) & Critério de Chauvenet & Resultado \\
\hline 5,25 & 0,90 & Ok \\
4,94 & 1,07 & Ok \\
5,14 & 0,17 & Ok \\
\hline Média & 5,11 & \\
Desvio padrão & 0,16 \\
Coeficiente de variação & 3,09 & \\
\hline \multicolumn{4}{c}{ Fonte: Elaborada pelo autor. } \\
\end{tabular}

Tabela A.24 - C25 9\% - Critério de Chauvenet para resultados de resistência à tração por flexão aos 28 dias.

\begin{tabular}{ccc}
\hline & C25 9\% - 28 Dias & \\
\hline Resistência (MPa) & Critério de Chauvenet & Resultado \\
\hline 4,21 & 0,85 & Ok \\
4,40 & 1,10 & Ok \\
4,27 & 0,25 & Ok \\
\hline Média & 4,29 & \\
Desvio padrão & 0,10 & \\
Coeficiente de variação & 2,28 \\
\hline
\end{tabular}


Tabela A.25 - C25 15\% - Critério de Chauvenet para resultados de resistência à tração por flexão aos 28 dias.

\begin{tabular}{|c|c|c|}
\hline \multicolumn{3}{|c|}{ C25 15\% - 28 Dias } \\
\hline Resistência (MPa) & Critério de Chauvenet & Resultado \\
\hline 3,24 & 0,03 & $\mathrm{Ok}$ \\
\hline 2,93 & 1,02 & Ok \\
\hline 3,52 & 0,98 & $\mathrm{Ok}$ \\
\hline Média & 3,23 & \\
\hline Desvio padrão & 0,30 & \\
\hline Coeficiente de variação & 9,14 & \\
\hline
\end{tabular}

Tabela A.26 - C40 referência - Critério de Chauvenet para resultados de resistência à tração por flexão aos 28 dias.

\begin{tabular}{ccc}
\hline \multicolumn{3}{c}{ C40 Referência - 28 Dias } \\
\hline Resistência (MPa) & Critério de Chauvenet & Resultado \\
\hline 8,70 & 0,93 & Ok \\
6,98 & 1,06 & Ok \\
8,01 & 0,13 & Ok \\
\hline Média & 7,90 \\
Desvio padrão & 0,86 \\
Coeficiente de variação & 10,95 \\
\hline \multicolumn{4}{c}{ Fonte: Elaborada pelo autor. } \\
\hline
\end{tabular}

Tabela A.27 - C40 9\% - Critério de Chauvenet para resultados de resistência à tração por flexão aos 28 dias.

\begin{tabular}{ccc}
\hline \multicolumn{3}{c}{ C40 9\% - 28 Dias } \\
\hline Resistência (MPa) & Critério de Chauvenet & Resultado \\
\hline 3,24 & 0,03 & Ok \\
2,93 & 1,02 & Ok \\
3,52 & 0,98 & Ok \\
\hline Média & 3,23 & \\
Desvio padrão & 0,30 & \\
Coeficiente de variação & 9,14 & \\
\hline \multicolumn{4}{c}{ Fonte: Elaborada pelo autor. } \\
\end{tabular}


Tabela A.28 - C40 15\% - Critério de Chauvenet para resultados de resistência à tração por flexão aos 28 dias.

\begin{tabular}{ccc}
\hline \multicolumn{4}{c}{ C40 - 15\% - 28 Dias } \\
\hline Resistência (MPa) & Critério de Chauvenet & Resultado \\
\hline 5,31 & 0,97 & Ok \\
4,74 & 1,03 & Ok \\
5,05 & 0,05 & Ok \\
\hline Média & 5,03 \\
Desvio padrão & 0,28 \\
Coeficiente de variação & 5,62 \\
\hline \multicolumn{4}{c}{ Fonte: Elaborada pelo autor. } \\
\hline
\end{tabular}




\section{APENDICE D - TESTE t PARA AVALIAÇÃO DE DIFERENÇA SIGNIFICATIVA ENTRE AMOSTRAS CONSIDERADAS}

Outro critério de análise estatística aplicado consiste no teste $t$, que, a partir dos valores médios obtidos para cada parâmetro, indica se existe diferença significativa entre diferentes amostras.

Tabela A.29 - Teste $\mathrm{t}$ - Resistência à compressão aos 28 dias.

\begin{tabular}{ccccccc}
\hline \multicolumn{6}{c}{ Teste estatístico - Resistência à compressão aos 28 dias } \\
\hline Tipo de concreto & GL & $\mathbf{t}$ & $\mathbf{P}(\mathbf{T}<=$ t) bi-caudal & t crítico & $\begin{array}{c}\text { Diferença } \\
\text { significativa? }\end{array}$ \\
\hline C25 ref. e C25 9\% & 6 & 25,345 & $2,48505 \mathrm{E}-07$ & 2,447 & Sim \\
C25 ref. e C25 15\% & 7 & 32,651 & $6,54089 \mathrm{E}-09$ & 2,365 & Sim \\
C25 9\% e C25 15\% & 7 & 14,761 & $1,56763 \mathrm{E}-06$ & 2,365 & $\mathrm{Sim}$ \\
C40 ref. e C40 9\% & 7 & 16,128 & $8,56618 \mathrm{E}-07$ & 2,365 & $\mathrm{Sim}$ \\
C40 ref. e C40 15\% & 8 & 22,471 & $1,62778 \mathrm{E}-08$ & 2,306 & $\mathrm{Sim}$ \\
C40 9\% e C40 15\% & 7 & 10,046 & $2,07572 \mathrm{E}-05$ & 2,365 & $\mathrm{Sim}$ \\
\hline \multicolumn{7}{c}{ Fonte: Elaborada pelo autor. }
\end{tabular}

Tabela A.30 - Teste $\mathrm{t}$ - Resistência à tração por compressão diametral aos 28 dias.

\begin{tabular}{ccccccc}
\hline \multicolumn{6}{c}{ Teste estatístico - Resistência à tração por compressão diametral aos 28 dias } \\
\hline Tipo de concreto & GL & $\mathbf{t}$ & $\mathbf{P}(\mathbf{T}<=$ t) bi-caudal & t crítico & $\begin{array}{c}\text { Diferença } \\
\text { significativa? }\end{array}$ \\
\hline C25 ref. e C25 9\% & 4 & 5,737 & 0,004572673 & 2,776 & Sim \\
C25 ref. e C25 15\% & 4 & 19,261 & $4,28237 \mathrm{E}-05$ & 2,776 & Sim \\
C25 9\% e C25 15\% & 4 & 5,871 & 0,00420303 & 2,776 & Sim \\
C40 ref. e C40 9\% & 4 & 37,182 & $3,12403 \mathrm{E}-06$ & 2,776 & $\mathrm{Sim}$ \\
C40 ref. e C40 15\% & 4 & 43,262 & $1,70685 \mathrm{E}-06$ & 2,776 & $\mathrm{Sim}$ \\
C40 9\% e C40 15\% & 4 & 7,774 & 0,001475977 & 2,776 & $\mathrm{Sim}$ \\
\hline
\end{tabular}


Tabela A.31 - Teste $\mathrm{t}$ - Resistência à tração por flexão aos 28 dias.

\begin{tabular}{ccccccc}
\hline \multicolumn{6}{c}{ Teste estatístico - Resistência à tração por flexão aos 28 dias } \\
\hline Tipo de concreto & GL & $\mathbf{t}$ & $\mathbf{P}(\mathbf{T}<=$ t) $)$ bi-caudal & t crítico & $\begin{array}{c}\text { Diferença } \\
\text { significativa? }\end{array}$ \\
\hline C25 ref. e C25 9\% & 4 & 7,6279 & 0,001586107 & 2,7764 & Sim \\
C25 ref. e C25 15\% & 4 & 9,7024 & 0,000631654 & 2,7764 & Sim \\
C25 9\% e C25 15\% & 4 & 5,8954 & 0,004140725 & 2,7764 & Sim \\
C40 ref. e C40 9\% & 4 & 8,8409 & 0,000903669 & 2,7764 & Sim \\
C40 ref. e C40 15\% & 4 & 5,4501 & 0,005505984 & 2,7764 & Sim \\
C40 9\% e C40 15\% & 4 & 7,6247 & 0,001588649 & 2,7764 & Sim \\
\hline \multicolumn{7}{c}{ Fonte: Elaborada pelo autor. } \\
\hline
\end{tabular}

Tabela A.32 - Teste t - Módulo de elasticidade dinâmico aos 28 dias.

\begin{tabular}{ccccccc}
\hline \multicolumn{6}{c}{ Teste estatístico - Módulo de elasticidade dinâmico aos 28 dias } \\
\hline Tipo de concreto & GL & $\mathbf{t}$ & P(T<=t) bi-caudal & t crítico & $\begin{array}{c}\text { Diferença } \\
\text { significativa? }\end{array}$ \\
\hline C25 ref. e C25 9\% & 4 & 15,6552 & $9,72282 \mathrm{E}-05$ & 2,7764 & Sim \\
C25 ref. e C25 15\% & 4 & 31,0909 & $6,37718 \mathrm{E}-06$ & 2,7764 & Sim \\
C25 9\% e C25 15\% & 4 & 10,7197 & 0,00042918 & 2,7764 & Sim \\
C40 ref. e C40 9\% & 4 & 52,7169 & $7,75018 \mathrm{E}-07$ & 2,7764 & Sim \\
C40 ref. e C40 15\% & 4 & 25,0242 & $1,51392 \mathrm{E}-05$ & 2,7764 & $\mathrm{Sim}$ \\
\hline C40 9\% e C40 15\% & 4 & 3,5421 & 0,023968926 & 2,7764 & $\mathrm{Sim}$ \\
\hline
\end{tabular}

O teste $\mathrm{t}$ também foi feito para as velocidades de pulso ultrassônico nas direções transversal e longitudinal, de maneira a avaliar se as duas direções poderiam ser consideradas em conjunto.

Tabela A.33 - C25 referência - Médias de velocidades por prisma aos 28 dias.

\begin{tabular}{cc}
\hline \multicolumn{2}{c}{ C25 ref. - 28 dias } \\
\hline Transversal (m/s) & Longitudinal (m/s) \\
\hline 4506,1 & 4446,2 \\
4570,2 & 4476,0 \\
4462,0 & 4403,0 \\
\hline \multicolumn{2}{c}{ Fonte: Elaborada pelo autor. }
\end{tabular}


Tabela A.34 - C25 9\% - Médias de velocidades por prisma aos 28 dias.

\begin{tabular}{cc}
\hline \multicolumn{2}{c}{ C25 9\% } \\
\hline Transversal (m/s) & Longitudinal $(\mathbf{m} / \mathbf{s})$ \\
\hline 4494,3 & 4262,8 \\
4335,1 & 4234,1 \\
4460,6 & 4129,7 \\
\hline \multicolumn{2}{c}{ Fonte: Elaborada pelo autor. }
\end{tabular}

Tabela A.35 - C25 15\% - Médias de velocidades por prisma aos 28 dias.

\begin{tabular}{cc}
\hline \multicolumn{2}{c}{ C25 15\% - 28 dias } \\
\hline Transversal (m/s) & Longitudinal (m/s) \\
\hline 4184,4 & 3982,1 \\
4063,0 & 3890,1 \\
4326,1 & 3962,3 \\
\hline
\end{tabular}

Fonte: Elaborada pelo autor.

Tabela A.36 - C40 referência - Médias de velocidades por prisma aos 28 dias.

\begin{tabular}{cc}
\hline \multicolumn{2}{c}{ C40 ref. - 28 dias } \\
\hline Transversal (m/s) & Longitudinal (m/s) \\
\hline 4705,0 & 4710,8 \\
4786,1 & 4685,2 \\
4702,0 & 4681,2 \\
\hline
\end{tabular}

Fonte: Elaborada pelo autor.

Tabela A.37 - C40 9\% - Médias de velocidades por prisma aos 28 dias.

\begin{tabular}{cc}
\hline \multicolumn{2}{c}{ C40 9\% - 28 dias } \\
\hline Transversal (m/s) & Longitudinal (m/s) \\
\hline 4614,5 & 4390,1 \\
4627,1 & 4352,9 \\
4581,4 & 4295,0 \\
\hline
\end{tabular}

Fonte: Elaborada pelo autor. 
Tabela A.38 - C40 15\% - Médias de velocidades por prisma aos 28 dias.

\begin{tabular}{cc}
\hline \multicolumn{2}{c}{ C40 15\% - 28 dias } \\
\hline Transversal (m/s) & Longitudinal (m/s) \\
\hline 4451,5 & 4162,2 \\
4379,9 & 4125,2 \\
4399,0 & 4128,6 \\
\hline
\end{tabular}

Fonte: Elaborada pelo autor.

Tabela A.39 - Teste $\mathrm{t}$ - Velocidades transversal e longitudinal aos 28 dias.

\begin{tabular}{ccccccc}
\hline \multicolumn{6}{c}{ Teste estatístico - Módulo de elasticidade aos 28 dias } \\
\hline Tipo de concreto & GL & $\mathbf{t}$ & $\mathbf{P}(\mathbf{T}<=\mathbf{t})$ bi-caudal & $\mathbf{t}$ crítico & $\begin{array}{c}\text { Diferença } \\
\text { significativa? }\end{array}$ \\
\hline C25 ref. & 4 & 1,875 & 0,134109873 & 2,776 & Não \\
C25 9\% & 4 & 3,504 & 0,024795312 & 2,776 & Sim \\
C25 15\% & 4 & 3,041 & 0,038363436 & 2,776 & Sim \\
C40 ref. & 4 & 1,329 & 0,254533942 & 2,776 & Não \\
C40 9\% & 4 & 8,484 & 0,001058245 & 2,776 & Sim \\
C40 15\% & 4 & 11,105 & 0,000374121 & 2,776 & Sim \\
\hline \multicolumn{7}{c}{ Fonte: Elaborada pelo autor. }
\end{tabular}

De acordo com Tabela A.39, as velocidades nas duas direções para os concretos com ar incorporado apresentam diferença significativa. Dessa maneira, os resultados não podem ser analisados em conjunto. 